РОССИЙСКАЯ АКААЕМИЯ ЕСТЕСТВЕННЫХ НАУК

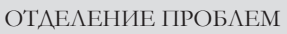

РААИОЭАЕКТРОНИКИ,

НАНОФИЗИКИ И

ИНФОРМАЦИОННЫХ

ТЕХНОАОГИЙ

\section{РЭНСИТ:}

РААИОЭАЕКТРОНИКА.

НАНОСИСТЕМЫ.

ИНФОРМАЦИОННЫЕ

ТЕХНОАОГИИ.

2016, том 8, № 2

ОСНОВАН В 2009 г. - печатное изАание С 2014 г. - печатное и сетевое изАание ВЫХОАИТ АВА РАЗА В ГОА МОСКВА

Главный редактор
Грачёв В.И.
grachev@сplire.ru
Omветственный секретарь
Беляев Р.В.
belyaev@cplire.ru
РЕААК

РЕААКЦИОННЫЙ СОВЕТ

Председатель

И^юшин А.C.

Заместитель председателя

Губин С.П.

Андреев A.B.

Баришполец В.А.

Бецкий О.В.

Бушуев В.А. - зам. гл. редактора

Амитриев А.С.

ИАюшин Я.А.

Козарь А.В.

Колесов В.В. - зам. гл. редактора

Корнилова А.А.

Макаров В.A.

Панас А.И.

Петров И.Б.

Русаков В.С.

Сигов А.C.

Силонов B.M.

Солаатов Е.С.

Фетисов Ю.К.

Черепенин В.А.

Верона Э. (Италия)

Кавазое Е. (Япония)

Кадыржанов К.К. (Казахстан)

Мак Кен Питер Пауль (США)

Сангаа Аэлег (Монголия)

Скиртач А. (Бельгия)

Уштурас Е.В. (Аитовская Республика)

Энхтор $\Lambda$. (Монголия)

ISSN 2218-3000

Журнал зарегистрирован в Министерстве связи

массовых коммуникаций Российской Федерации.

СвиАетельство ПИ №ФС77-38976 от 02.03.2010 г.

Bсе права защищены. Никакая часть этого издани не может быть репродуцирована в какой-Аибо форм без письменного разрешения издателя.

CPAEH 2016

ААРЕС РЕААКЦИИ:

125009 МОСКВА, РОССИЙСКАЯ ФЕАЕРАЦИЯ,

ул. Моховая, 11, корп. 7, к. 218-219,
тел. +7 4956293368 , факс 4956293678 Грачеву В.И Отпечатано в типографии "Тверской Печатный Авор"

170518 Тверская область, Калининский район,
Никольское, А. 26 .

\section{СОАЕРЖАНИЕ}

\section{РАДИОЭЛЕКТРОНИКА}

НЕСТАЦИОНАРНОЕ ОТРАЖЕНИЕ

СВЕРХКОРОТКИХ ЭАЕКТРОМАГНИТНЫХ

ИМПУАЬСОВ ОТ САОИСТЫХ СТРУКТУР

Трофимов А.И., Козарь А.В.

107

\section{НАНОСИСТЕМЫ}

DIRAC MATERIAL GRAPHENE

Elena F. Sheka 131

АВУХСАОЙНЫЙ ГРАФЕН КАК МЕМБРАНОМИМЕТИК: МОАЕАИРОВАНИЕ ИОННЫХ КАНААОВ

Градов О.В., Градова М.А. 154

АИСПЕРСИИ НАНОЧАСТИЦ В ВОАНО-

ОРГАНИЧЕСКИХ РАСТВОРИТЕАЯХ КАК ОСНОВА СЕРЕБРЯНЫХ НАНОЧЕРНИ А Я 2D ПЕЧАТИ

Ткачев С.В., Ким В.П., Кушнир А.Е., Корнилов А.Ю., Губин С.П. 171

\section{ИНФОРМАЦИОННЫЕ ТЕХНОЛОГИИ}

ПРИМЕНЕНИЕ ТЕХНОАОГИЙ ПАРА АЕ ЬНОГО ПРОГРАММИРОВАНИЯ ААЯ МОАЕАИРОВАНИЯ СЕЙСМИЧЕСКИХ ВОАН СЕТОЧНО-

ХАРАКТЕРИСТИЧЕСКИМ МЕТОАОМ

Иванов А.М., Хохлов Н.И., Петров И.Б. 185

\section{НЕЛИНЕЙНАЯ ТЕРМОДИНАМИКА}

ОБНАРУЖЕНИЕ И ИССАЕАОВАНИЕ АНОМААЬНЫХ (НЕЗАТУХАЮЩИХ) ТЕП ОВЫХ ВО $Н$

Высоцкий В.И., Корнилова А.А., Василенко А.О.,

Высоцкий М.В., Хаит Е.И., Волкова Н.Х. 196

\section{ФРАКТАЛЫ В ФИЗИКЕ}

КВАЗИСИММЕТРИЯ ФУРЬЕ-ОБРАЗОВ

ОБОБЩЕННЫХ ТРИААНЫХ ПРЕАФРАКТААОВ KOXA

Арзамасцева Г.В., Евтихов М.Г., Аисовский Ф.В.

Мансветова Е.Г. 207

\section{ТЕОРИЯ ЭВОЛЮЦИИ}

ЭВОАЮЦИОННЫЕ АСПЕКТЫ ПОЯВАЕНИЯ ГЕАЯ И ЕГО ФУНКЦИЙ В ЦИТОПААЗМЕ КАЕТОК

Зарицкий А.Р., Грачев В.И., Зайцева Г.В., Кириченко М.Н. .215

\section{ХРОНИКА}

ГРАФЕНИКА. РОССИЙСКИЙ СЕМИНАР С.П.

ГУБИНА (МОСКВА)

Буслаева Е.Ю. 223 


\section{RADIOELECTRONICS}

NONSTATIONARY REFLECTION OF A SUPERSHORT ELECTROMAGNETIC PULSES FROM THE LAYERED STRUCTURES

Alexey V. Trofimov, Anatoly V. Kozar' 107

\section{$\overline{\text { NANOSYSTEMS }}$}

DIRAC MATERIAL GRAPHENE

Elena F. Sheka

CAN GRAPHENE BILAYERS BE THE MEMBRANE MIMETIC MATERIALS? SIMULATION OF ION CHANNELS

Oleg V. Gradov, Margarita A. Gradova

THE DISPERSIONS OF NANOPARTICLES IN WATERORGANIC SOLVENTS AS THE BASIS FOR THE SILVER NANO-INK FOR INK-JET PRINTING

Sergey V. Tkachev, Vitalii P. Kim, Alexey E. Kushnir, Denis Yu. Kornilov, Sergey P. Gubin

\section{INFORMATION TECHNOLOGIES}

THE USE OF PARALLEL PROGRAMMING TECHNOLOGIES FOR MODELING SEISMIC WAVES USING GRIDCHARACTERISTIC METHOD

Andrey M. Ivanov, Nikolay I. Khokhlov, Igor B. Petrov

\section{NON-LINEAR THERMODYNAMICS}

DETECTION AND INVESTIGATION OF ANOMALOUS (UNDAMPED) THERMAL WAVES

Vladimir I. Vysotskii, Alla A. Kornilova, Anton O. Vasilenko, Mikhail V. Vysotskyy, Efim I. Hait, Nailia H. Volkova

\section{FRACALS IN PHYSICS}

QUASISYMMETRY OF FOURIER TRANSFORMS OF

GENERALIZED TRIAD KOCH'S PREFRACTALS

Galina V. Arzamastseva, Mikhail G. Evtikhov, Feodor V. Lisovsky,

Ekaterina G. Mansvetova

\section{THEORY OF EVOLUTION}

EVOLUTIONARY ASPECTS OF THE GEL APPEARANCE AND ITS FUNCTIONS IN THE CELL CYTOPLASM

Alexander R. Zaritsky, Vladimir I. Grachev, Galina V. Zaytseva, Marina N. Kirichenko

\section{CHRONICLE}

GRAFENIKA [GRAPHENICS].

RUSSIAN GUBIN'S SEMINAR (MOSCOW)

Elena Yu. Buslaeva
2 ISSUES PER YEAR

RUSSIAN ACADEMY OF NATURAL SCIENCES

DEPARTMENT OF RADIOELECTRONICS, NANOPHYSICS AND INFORMATION TECHNOLOGIES PROBLEMS

RENSIT:

RADIOELECTRONICS.

NANOSYSTEMS. INFORMATION TECHNOLOGIES.

2016, VOL. 8, № 2

FOUNDED IN 2009

4 мoscow

Editor-in-Chief

VLADIMIR I. GRACHEV

grachev@cplire.ru

Executive Secretary

Rostislav V. BeLyaeV

belyaev@cplire.ru

171 EDITORIAL COUNCIL

Chairman

Alexander S. Ilushin

Deputy Chairman

Sergey P. Gubin

Anatoly V. Andreev

Vitaly A. Barishpolets

Oleg V. Betzkiy

Vladimir A. Bushuev - deputy chief

185 Vladimir A. Cherepenin

Alexander S. Dmitriev

Yuri K. Fetisov

Yaroslav A. Ilushin

Anatoly V. Kozar

Vladimir V. Kolesov - deputy chief Albina A. Kornilova

Vladimir A. Makarov

Andrey I. Panas

Igor B. Petrov

Vyacheslav S. Rusakov

Alexander S. Sigov

Valentine M. Silonov

Eugeny S. Soldatov

Lkhamsuren Enkhtor (Mongolia) Yoshiyuki Kawazoe (Japan)

Kairat K. Kadyrzhanov (Kazakhstan) Peter Paul Mac Ken (USA)

Andre Skirtach (Belgium)

Deleg Sangaa (Mongolia)

Enrico Verona (Italy)

Eugeny V. Ushpuras (Republic of Lithuania)

\section{ISSN 2414-1267}

The journal on-line is registered by the Ministry of Telecom and Mass Cjmmunications of the 215 Russian Federation. Certificate El. no. FS77Russian Federation.

All rights reserved. No part of this publication may be reproduced in any form or by any mean ORANS 2016

EDITORIAL BOARD ADDRESS

218-219 of., 7 b., 11, Mokhovaya str.,

125009 MOSCOW, RUSSIAN FEDERATION, 223 TEL. +74956293368 FAX +74956293678 FOR GRACHEY 


\section{НЕСТАЦИОНАРНОЕ ОТРАЖЕНИЕ СВЕРХКОРОТКИХ ЭАЕКТРОМАГНИТНЫХ ИМПУАЬСОВ ОТ САОИСТЫХ СТРУКТУР}

Трофимов А.В., Козарь А.В.

Московский государственный университет им. М.В. Аомоносова, физический факультет, http:/ /www.msu.ru 119991, Москва Российская Федерация

Поступила в редакиило 13.12.2016

ПровеАено теоретическое и численное исследование нестационарного отражения коротких и сверхкоротких электромагнитных импульсов СВЧ от оАнослойной и многослойной интерференционных структур, создан экспериментамьный стенА А^я измерения нестационарного отражения амплитудно-модумированного сигнала от слоистой структуры. Показано, что огибающая отраженного сигнаца существенно изменяет свой виА при намичии Ааже малых потерь в слоях неотражающей многослойной структуры, причем амплитудный коэффициент отражения минейно зависит от вемичины потерь. При малых потерях в слоях структуры огибающая отраженного сигнала может быть приближенно описана $\mathrm{N}$-производной от огибающей падающего сигнала. Получены точные и приближенные формулы, позволяющие рассчитать характеристики многослойной интерференционной структуры, согласующей высокоотражающую нагрузку с волноводом, за счет сильной волноводной дисперсии. Показано, что в многослойных интерференционных структурах с сильной волноводной Аисперсией происходит существенное усиление амплитуды и увеличение Амительности импульсов нестационарного отражения.

Ключевъе слова: электромагнитные сверхкороткие импульсы СВЧ, слоистые структуры с потерями и сильной волноводной дисперсией, нестационарное отражение, огибающая отраженного сигнала, высокоотражающая нагрузка исогласующие структуры, многослойные интерференционные фильтры

УАК 544.77, 53.098

\section{СОАЕРЖАНИЕ}

1. ВВеАЕНИЕ (107)

2. НЕСТАЦИОНАРНОЕ ОТРАЖЕНИЕ ЭАЕКТРОМАГНИТНОГО ИМПУАЬСА ОТ ОАНОСАОЙНЫХ СТРУКТУР (111)

2.1. ВАИЯНИЕ ПОТЕРЬ В САОЕ НА НЕСТАЦИОНАРНОЕ ОТРАЖЕНИЕ (111)

2.2. ОТРАЖЕНИЕ ОТ САОЕВ $\mathrm{N} \lambda / 2$ (116)

2.3. ВАИЯНИЕ ВОАНОВОАНОЙ АИСПЕРСИИ (118)

2.4. ЭКСПЕРИМЕНТААЬНОЕ ИССАЕАОВАНИЕ ОТРАЖЕНИЯ СИГНААА ОТ ПОАУВОАНОВОГО ФИАьТРА (119)

2.4.1. ВАИЯНИЕ ПОТЕРЬ В САОЕ НА НЕСТАЦИОНАРНОЕ ОТРАЖЕНИЕ (120)

2.4.2. ВАИЯНИЕ ТОАщИНЫ САОЯ НА НЕСТАЦИОНАРНОЕ ОТРАЖЕНИЕ (121)

2.4.3. ВАИЯНИЕ ВОАНОВОАНОЙ АИСПЕРСИИ НА НЕСТАЦИОНАРНОЕ ОТРАЖЕНИЕ (121)

3. НЕСТАЦИОНАРНОЕ ОТРАЖЕНИЕ В УСАОВИЯХ СИАЬНОЙ ВОАНОВОАНОЙ АИСПЕРСИИ (123)

4. НЕСТАЦИОНАРНОЕ ОТРАЖЕНИЕ В МНОГОСАОЙНЫХ ИНТЕРФЕРЕНЦИОННЫХ ФИАЬТРАХ (125)

5. ЗАКАЮЧЕНИЕ (127)

АИТература (128)

\section{1. ВВЕАЕНИЕ}

Основной тенденцией развития оптических и микроволновых устройств в последнее Аесятилетие является непрерывное уменьшение Алительности используемых в них электромагнитных импульсов. Сверхкороткие электромагнитные импульсы все чаще применяются как Аля научных исследований, так и в промышленности [1-3]. В связи с этим становятся особенно актуальными вопросы генерации, управления и детектирования таких импульсов. Отмеченная тенденция наблюдается в Аитературных источниках, посвящённых исследованиям в оптическом [4-14], в милциметровом и субмицлиметровом диапазонах $[15,16]$.

Оптические импульсы, имеющие Алительность от Аесятков фемтосекунА Ао еАиниц аттосекунА, используются при исследовании сверхбыстрых процессов в биологии [1] и химии [2]. Большая мгновенная мощность импульсов 
используется при исследовании нелинейных процессов в полупроводниковых материалах и устройствах [3]. В милииметровом диапазоне

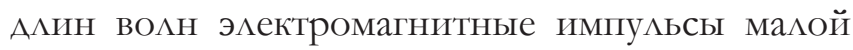
Алительности также нашли свое применение, в первую очередь - в радиолокации $[15,16]$.

Обозначенные тенденции развития микроволновой и оптической техники приводят к необходимости создания новых и усовершенствования уже существующих устройств Аля управления сверхкороткими электромагнитными импульсами.

Аля управления сигналами большой Алительности широко применяются многослойные интерференционные структуры (МИС). На сегодняшний день МИС активно используются в устройствах, работающих как в мицАиметровом, так и в оптическом диапазоне Алин волн. Методы их анализа и синтеза Аостаточно хорошо отработаны.

Попытки применить МИС Аля управления сверхкороткими импульсами выявили наличие целого ряла новых эффектов [11, 17 20], не наблюдаемых при взаимодействии с МИС сигналов большой Алительности. При взаимодействии электромагнитного сигнала с многослойной структурой в результате интерференции волн, отражённых от её слоев, формируются прошедший и отражённый сигналы. При большой Алительности палающего сигнала время установ ения стационарного процесса в многослойной структуре пренебрежимо мало по сравнению с Алительностью сигнала, поэтому влияние нестационарного процесса на формирование отраженного и прошедшего сигналов не рассматривается. Аля коротких импульсов, поА которыми понимаются импульсы с Алительностью не более 100 периодов колебаний электромагнитного поля [21], Алительность переходного процесса может стать сравнимой с Алительностью сигнаца, поэтому учет вАияния нестационарного процесса на формирование отраженного и прошедшего сигнацов становится необходимым.

На сегодняшний Аень исследования по взаимодействию сверхкоротких импульсов с многослойными интерференционными структурами активно ведутся в разАичных направлениях. Аостаточно глубоко изучено взаимодействие сверхкоротких импульсов с зеркалами на основе МИС. Созданы многослойные зеркала, способные не только эффективно отражать короткие электромагнитные импульсы, но даже уменьшать Алительность отраженного сигнала, по сравнению с палающим сигналом [4-7].

Вопросы взаимодействия сверхкоротких импульсов со структурами неотражающего типа на основе МИС, в частности - с многослойными интерференционными фильтрами, освещены менее обширно, хотя и в этой области за последние Аесять мет появилось большое число публикаций [8-14].

Несмотря на высокую интенсивность исследований взаимодействия сверхкоротких электромагнитных импульсов с МИС, существует ряд явлений, которые недостаточно хорошо изучены и освещены как в отечественной, так и в зарубежной митературе. К одному из таких яв ений можно отнести явление нестачионарного отражения электромагнитных импульсов мацой Алительности от МИС. Недостаточный объем исследований по этому вопросу, в первую очередь, вызван особенностью наблюдения Аанного явления. Например, при изучении процессов, происходящих при взаимодействии коротких электромагнитных импульсов с многослойными зеркалами, анализировать процесс нестационарного отражения достаточно сложно, так как интенсивность основного отражённого сигнаца от зеркалаво много раз выше интенсивности сигнала, сформировавшегося в результате нестационарного отражения.

В подавАяющем большинстве публикаций, посвященных вопросу взаимодействия электромагнитных импульсов малой Алительности с многослойными структурами неотражающего типа, отраженный сигнац рассматривается как нежелательный. Поэтому при синтезе МИС, отраженный сигнац (в том числе содержащий в себе импульсы, сформированные в процессе нестационарного отражения) стараются подавить, как правицо, численными алгоритмами оптимизации, не анализируя механизм его появ ения.

ОАними из первых работ, посвященных изучению явления нестационарного 
отражения сверхкоротких импульсов от МИС неотражающего типа, были [17, 18, 22-24]. В них впервые введено понятие "нестационарное отражение" и проанализированы процессы, происходящие при отражении электромагнитного импульсамалойдАительности

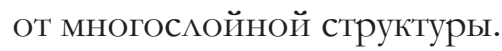

Как известно [25], при падении электромагнитной волны на слоистую структуру в результате интерференции в ее слоях через некоторое время $t_{\mathrm{s}}$ в структуре установится стационарное распределение электромагнитного поля. При этом амплитуда волны, отраженной от структуры, будет стремиться к нулю, как результат негативной интерференции волн в просветляющей многослойной структуре. ОАнако если в течение некоторого времени $t_{\mathrm{p}}-$ меньшего времени установления стационарного распределения поля в слоях $t_{\mathrm{s}}$ - происходит изменение параметров (амплитуды или фазы) паАающего сверхкороткого импульса, то, нарушается амплитудно-фазовый баланс интерферирующих в многослойной структуре во н, изменяется стационарное распределение поля волны в структуре в течение времени $t_{\mathrm{p}}$ и появхяется отраженный сигнац. Таким образом, изменение амплитуды волны, падающей на многослойную структуру, приведет к изменению амплитуды сигнала, отраженного от многослойной структуры. В случае же, если стационарный сигнац отсутствует - например, если волна отражена от просветляющей структуры или волна прошла через многослойное зеркало - появится отраженный (А^я просветАяющей структуры)

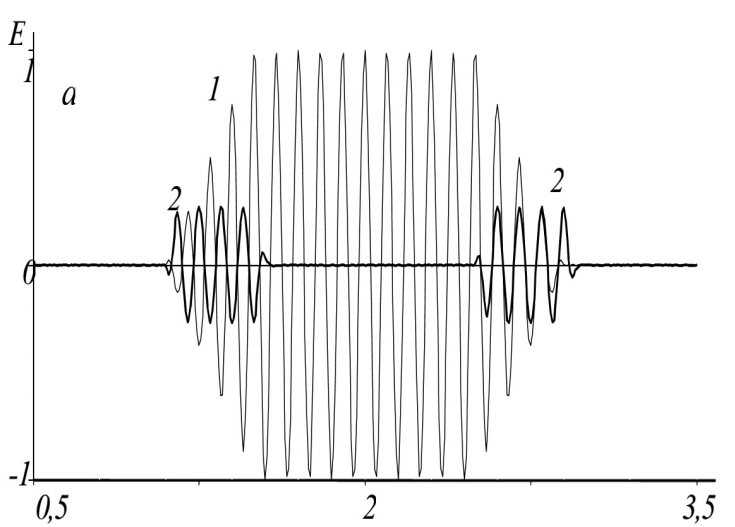

(a) или прошеАший (ААя многослойного зеркала) импульсный сигнал соответствующей Алительности.

В работе [17] анализ процесса нестационарного отражения производился на примере четвертьволновой пленки, нанесенной на подложку. Получено аналитическое решение Аля амплитуды огибающей отраженного от структуры сигнала с амплитудной моАуляцией в следующем виде

$$
U(t)=\frac{r_{0}}{1-r_{0}^{2}}\left[\sum_{n-1}^{\infty} \frac{1}{n !} \frac{d^{n} A(t)}{d t^{n}}(2 k+1) \frac{T}{2}\right] e^{i \omega t},
$$

гАе $U(t)$ - амплитуда огибающей отраженной волны, $r_{0}$ - коэффициент отражения Френеля от материала пленки, $A(t)$ - амплитуда огибающей падающего сигнала, $T$ - период колебаний волны в импульсе, $k=0,1,2 \ldots-$ кратность толщины пленки четверти Алины волны, $\omega$ - круговая частота. В работах [17, 24] были рассчитаны зависимости амплитуды отраженных сигналов при падении на просветляющую структуру импульсов с трапецеилальной и гауссовой огибающими (рис. 1 a, b). Полученное в этих работах Аля некоторых типов просветляющих периодических структур аналитическое выражение может быть использовано Аля анализа временного хода амплитуды спектральноограниченных импульсов.

В работе [18] было проанализировано взаимодействие электромагнитных импульсов с фазовой и частотной модуляцией от широкого класса просветляющих структур - тонкослойных интерференционных согласователей (ТИС). Теория амплитудноспектральных, структурных и инвариантных свойств ТИС была разработана

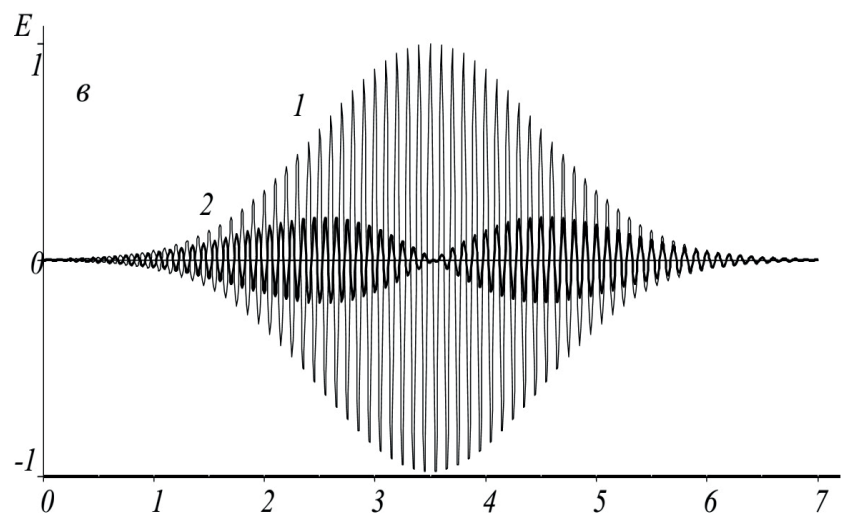

(b)

Рис. 1. Напряненности электрического поля отраженного сигнала для падаюочего импульса с трапечеидальной огибатощей (a) и (b) супергауссовой огибаюощей 1) падающего сигнала; 2) отражненного сигнала [24]. 
в $[26,27]$. В работе рассматривался импульс с супергауссовой огибающей виАа:

$$
\begin{aligned}
& E_{0}=A(t) \mathrm{e}^{-\mathrm{i} \varphi(t)} \\
& A(t)=e^{\left(\frac{t}{\tau}\right)^{2 p}},
\end{aligned}
$$

$\varphi(\mathrm{t})$ - изменяющаяся во времени действительная фаза. В предположении кваАратичной фазовой модуляции $\varphi(t)=\alpha t^{2} / 2[28,29]$ (наиболее интересной с точки зрения приложений), Аля комплексной амплитуды отраженной волны было получено следующее выражение:

$$
E_{r}(t)=r_{0} \frac{A(t) e^{-i \varphi(t)}-A(t-\Delta t) e^{[-i \varphi(t-\Delta t)]}}{1-r_{0} e^{i[\varphi(t)-\varphi(t-\Delta t)]}},
$$

здесь $\Delta t-$ время пробега волной удвоенной толщины пленки. Выражение А^я огибающей отраженной волны ФМ-импульса имеет вид [18]:

$$
E_{0 r}(t)=\left|r_{0}\right| \frac{A(t)^{2}-2 A(t) A(t-\Delta t) \cos (\phi(t))+A^{2}(t-\Delta t)}{1-2 r_{0}^{2} \cos (\phi(t))+r_{0}^{4}},
$$

Полученные в [18] аналитические выражения позволяют выделить временной хоА фазовой модуляции (ФМ) импульсов. Это следует из того, что в аналитическом выражении (4) Аля амплитуды сохраняется информация о фазовой модуляции в виде функции $\varphi(t)$. Если с помощью корреляционных или прямых методов получены огибающие падающего импульса $\mathrm{A}(t)$ и отраженного $E_{0}$, то, используя (4), можно определить фазовую функцию $\varphi(t)$.

На рис. 2 представлены результаты расчета спектральным методом формы отраженных $Ф \mathrm{M}$ импульсов от пленки, нанесенной на подложку с $n_{\mathrm{s}}=3.42$. В обоих случаях Алительность импульсов $\tau$ была равна 7 нс, Алина волны несущей $\lambda=1.5$ мкм; Аля гауссова импульса $\alpha \tau^{2}=1$, Аля супергауссова импульса $\alpha \tau^{4}=4$, в выражении (3) параметр $p=3$. Огибающая отраженных импульсов $E_{0 \mathrm{r}}$ построена по формуле (5). Приведенные результаты получены с помощью Фурье-преобразования падающего импульса, взятого в виле:

$$
E(t)=A(t) e^{\left[-i\left(\omega_{0} t+\varphi(t)\right)\right]} .
$$

На практике часто встречаются ситуации, когАа ФМ импульсы приобретают плоскую или почти плоскую вершину. Аля этого случая в [18] получено следующее соотношение

$$
E_{r}=\frac{r_{0}}{1-r_{0}^{2}} \varphi(t)
$$

Аанный результат (7) указывает на перспективность применения явления нестационарного отражения Аля преобразования электромагнитных импульсов.

В [18] отмечено, что ТИС могут быть использованы как Аля анализа временной зависимости фазы ФМ импульсов, так и Аля получения сверхкоротких импульсов с указанными выше свойствами.

Явление нестационарного отражения, в силу обуславливающих его физических особенностей (отсутствие фонового отражения падающего излучения, адекватная зависимость его амплитудно-временных характеристик от формы падающего импульса и физических свойств, обрамляющих структуру среА), позволяет не только относительно просто получать сверхкороткие электромагнитные импульсы, но и разработать методики анализа параметров импульсов и нестационарных процессов в слоистых средах.

Следует отметить, что в рассмотренных работах не было уделено внимание ряду важных деталей, например - влиянию потерь в слоях структуры и Аисперсии на
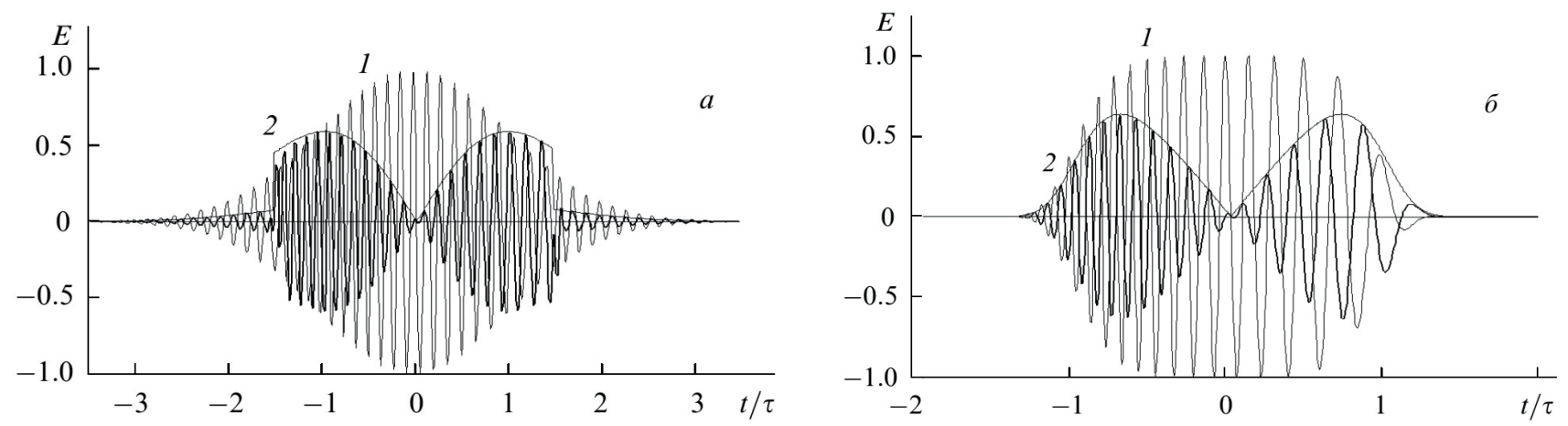

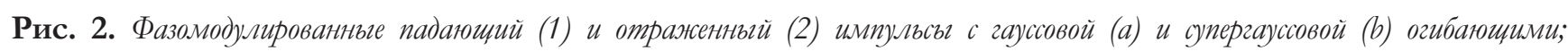
отраженные импульсы увеличены в 7 раз (а) и в 2 раза (b) [24]. 
процесс нестационарного отражения. Более того, проведенные исследования носили аналитический или численный характер без экспериментальных исследований. Все это обуславливает интерес и необходимость АаАьнейшего изучения явления нестационарного отражения, а также возможностей и условий его практической реализации.

Целью настоящей работы явцяется проведение детальных теоретических и экспериментальных исследований явления нестационарного отражения коротких и сверхкоротких электромагнитных импульсов от многослойных интерференционных структур, вкАючая анализ влияния сильной воАноводной Аисперсии, неоднородностей и потерь в многослойной структуре, на процесс формирования отраженного сигнала.

\section{2. НЕСТАЦИОНАРНОЕ ОТРАЖЕНИЕ ЭАЕКТРОМАГНИТНОГО ИМПУАЬСА ОТ ОАНОСАОЙНЫХ СТРУКТУР}

\section{1. ВАияние потерь в слое на нестационарное}

\section{отражение}

В качестве однослойной структруры использовался неотражающий в стационарном режиме слой Аиэлектрика, толщина которого кратна полуволновой оптической толщине, помещенный межАу Авумя идентичными по волновым характеристикам средами. Аанная структура является простейшей реализацией полуволнового интерференционного фильтра.

А^я анализа распространения волны через слоистую структуру с потерями использовался метоА импедансных характеристик [30-32]. При этом понятие импеданса вводится как отношение тангенциальных состав яющих напряженности электрического и магнитного полей в Аанном сечении слоистой структуры.

Пусть некоторая среда, преАставляющая собой плоскопаралмельный слой с комплексной относительной Аиэлектрической проницаемостью $\varepsilon=\varepsilon^{\prime}+i \varepsilon^{\prime \prime}$ и толщиной $d$, полностью заполняет поперечное сечение волновода с волновым сопротивлением $Z_{0}$, регулярного с обеих сторон. А^я Аальнейшего рассмотрения введем индекс $j$, обозначающий номер слоя. При этом индексацию будем производить таким образом, что ближайший

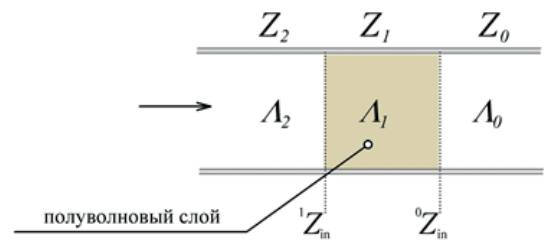

Рис. 3. Аиэлектрический слой в волноводе.

К источнику слой изАучения будет иметь максимальный индекс. На рис. 3 представлено направление распространения электромагнитной волны от источника и обозначены импедансы слоев $Z$, а также входные импедансы на границе слоев ${ }^{i} Z_{\text {in }}$. Выражения Аля постоянной распространения волны $\gamma_{j}$ и импеданса $Z_{j}$ имеют BиА:

$\gamma_{j}=\alpha_{j}+i \beta_{j}$

$\alpha_{j}=\frac{2 \pi}{\lambda} \sqrt{\frac{\sqrt{\varepsilon_{j}^{\prime \prime 2}+\Lambda_{j}^{2}}-\Lambda_{j}}{2}} ; \beta_{j}=\frac{2 \pi}{\lambda} \sqrt{\frac{\sqrt{\varepsilon_{j}^{\prime \prime 2}+\Lambda_{j}^{2}}+\Lambda_{j}}{2}} ;$

$Z_{\mathrm{j}}=C_{\mathrm{j}}+i D_{\mathrm{j}}$,

$C_{j}=\sqrt{\frac{\sqrt{\varepsilon_{j}^{\prime \prime 2}+\Lambda_{j}^{2}}+\Lambda_{j}}{2\left(\varepsilon_{j}^{\prime \prime 2}+\Lambda_{j}^{2}\right)}} ; D_{j}=\sqrt{\frac{\sqrt{\varepsilon_{j}^{\prime \prime 2}+\Lambda_{j}^{2}}-\Lambda_{j}}{2\left(\varepsilon_{j}^{\prime \prime 2}+\Lambda_{j}^{2}\right)}} ;$

Аля анализа многослойной структуры, установленной в волноводе, необходимо Аополнительно учесть явление волноводной Аисперсии. В этом случае:

$\Lambda_{j}=\varepsilon_{j}^{\prime}-\left(\frac{\lambda}{\lambda_{c}}\right)^{2}$,

$\lambda_{c}$ - критическая Алина волны в волноводе Аля моды $H_{10}, \lambda_{c}=2 a, a-$ размер широкой стенки волновода, $\lambda$ - Алина волны в свободном пространстве.

Выражение Аля коэффициента отражения на границе межАу участком свободного волновода и участком с установленным Аиэлектрическим слоем запишется как:

$$
\begin{aligned}
& r=\frac{{ }^{1} Z_{\text {in }}-Z_{0}}{{ }^{1} Z_{\text {in }}+Z_{0}}, \\
& Z_{0}=\frac{1}{\sqrt{1-\frac{\lambda}{\lambda_{c}}}} .
\end{aligned}
$$

Величина ${ }^{1} Z_{\text {in }}$, входящая в выражение Аля коэффициента отражения, которая может быть рассчитана с помощью следующего рекуррентного соотношения:

${ }^{1} Z_{\text {in }}=\frac{{ }^{0} Z_{\text {in }}+Z_{1} \operatorname{th}\left(\gamma_{1} d\right)}{Z_{1}+{ }^{0} Z_{\text {in }} \operatorname{th}\left(\gamma_{1} d\right)} Z_{1}$. 
В рассматриваемом случае Аля уединенного слоя, установленного в регулярном волноводе: ${ }^{0} Z_{\text {in }}=Z_{0}$.

Оценим влияние потерь в уединенном Аиэлектрическом полуволновом слое на спектр нестационарного отражения амплитудно-модулированного

сигнала.

Мнимая часть относительной Аиэлектрической проницаемости є", отвечающая за потери, входит как в выражения Аля импеданса слоя $(10,11)$ так и в выражение Аля постоянной распространения $(8,9)$. А^я упрощения залачи примем во внимание, что подавляющее большинство материалов, используемых А^я синтеза многослойных структур, обладают низкими потерями $\varepsilon^{\prime \prime} / \varepsilon^{\prime}<<1$. Считая потери в пластинке небольшими, введем малую величину $\xi_{1}=\frac{\varepsilon_{1}^{\prime \prime}}{\Lambda_{1}} \ll 1$. Тогда после нес $\Lambda$ жных преобразований Аля входного импеданса и постоянной распространения, с точностью АО величин первого порядка малости, получим следующие выражения:

$$
\begin{aligned}
& Z_{1} \approx \frac{1}{\sqrt{\Lambda_{1}}}+i \frac{\xi_{1}}{2 \sqrt{\Lambda_{1}}} ; \\
& \gamma_{1} \approx \frac{2 \pi}{\lambda} \sqrt{\Lambda_{1}}\left(\frac{\xi_{1}}{2}+i\right) .
\end{aligned}
$$

Аля коэффициента отражения от Аиэлектрической пластинки после подстановки (17) и (18) в (15), а затем в (13) будем иметь:

$$
r \approx \xi_{1} \frac{\pi}{\sqrt{\Lambda_{1}}} \frac{\left(1-Z_{0}^{2} \Lambda_{1}\right)}{4 Z_{0}}
$$

Из соотношения (19) виАно, что в случае малых потерь коэффициент отражения по

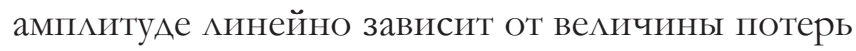
в слое. Кроме того, коэффициент отражения является чисто Аействительной величиной и, следовательно, малые потери в слое не будут влиять на фазовые соотношения межАу переотраженными волнами, т.е. фазовая картина отраженного сигнаца будет формироваться так же, как и в случае отсутствия потерь.

Проведен численный расчет зависимости коэффициента отражения от полуволнового

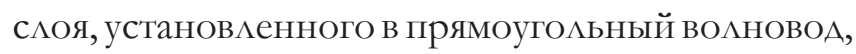
при условии $\nu_{0} / \nu_{c} \approx 1.3$, где $\nu_{c}-$ критическая частота. Учет волноводной Аисперсии приводит к тому, что на одинаковой отстройке от центральной частоты $\nu_{0}$ коэффициент отражения имеет разные значения. Расчет показац, что минимум коэффициента отражения остается на одной и той же частоте А^я разАичных значений мнимой части относительной Аиэлектрической проницаемости слоя $(\varepsilon=2+0.0 i, \varepsilon=2+0.01 i$ и $\varepsilon=2+0.05 i)$, что свидетельствует о постоянстве фазового баланса интерферирующих в слое волн. Отрицательная величина $r$ в выражении (19) показывает, что отражение от слоя происходит в противофазе по отношению к падающей волне, а фаза коэффициента отражения $\varphi_{\mathrm{r}}=\pi$. Таким образом, в случае наличия малых потерь в полуволновом слое происходит нарушение только амплитудного баланса интерферирующих волн, что, в свою очередь, приводит к появлению отраженного сигнала.

Процесс формирования отраженного сигнала при падении амплитудно-модулированного сигнала на полуволновой слой с потерями. рассмотрен на примере симметричного трапецеилального импульса с иинейными фронтами. Пусть волна падает на полуволновой слой с относительной Аиэлектрической проницаемостью $\varepsilon=2+0.05 i$. Будем считать, что Алительность трапецеилального импульса $\tau$ много больше времени прохода волной уАвоенной толщины слоя. При этом в результате нестационарного отражения будет сформирован электромагнитный импульс, распространяющийся навстречу паАающей волне. ЗаАаАим толщину слоя равной $d=30$ мм, а частоту несущей выберем так, что слой будет явцяться полуволновым. На рис. 4 представ $е н$ результат расчета методом конечных разностей во временной области (Finite Difference Time Domain, FDTD, или Yee algorithm) [33, 34] напряженности поля отраженного импульса $E_{\mathrm{r}}(t)$. Аля наглядности амплитуда отраженного сигнала увеличена в 10 раз.

Отметим, что, как при расчете методом конечных разностей во временной области, так и при проведении реального эксперимента, отсутствует возможность фиксировать отраженный сигнац непосредственно на границе Аиэлектрического слоя. От момента генерации сигнала до момента фиксации отраженного импульса АОАжно пройти некоторое время. ВсегАа существует, пусть и небольшое, расстояние 

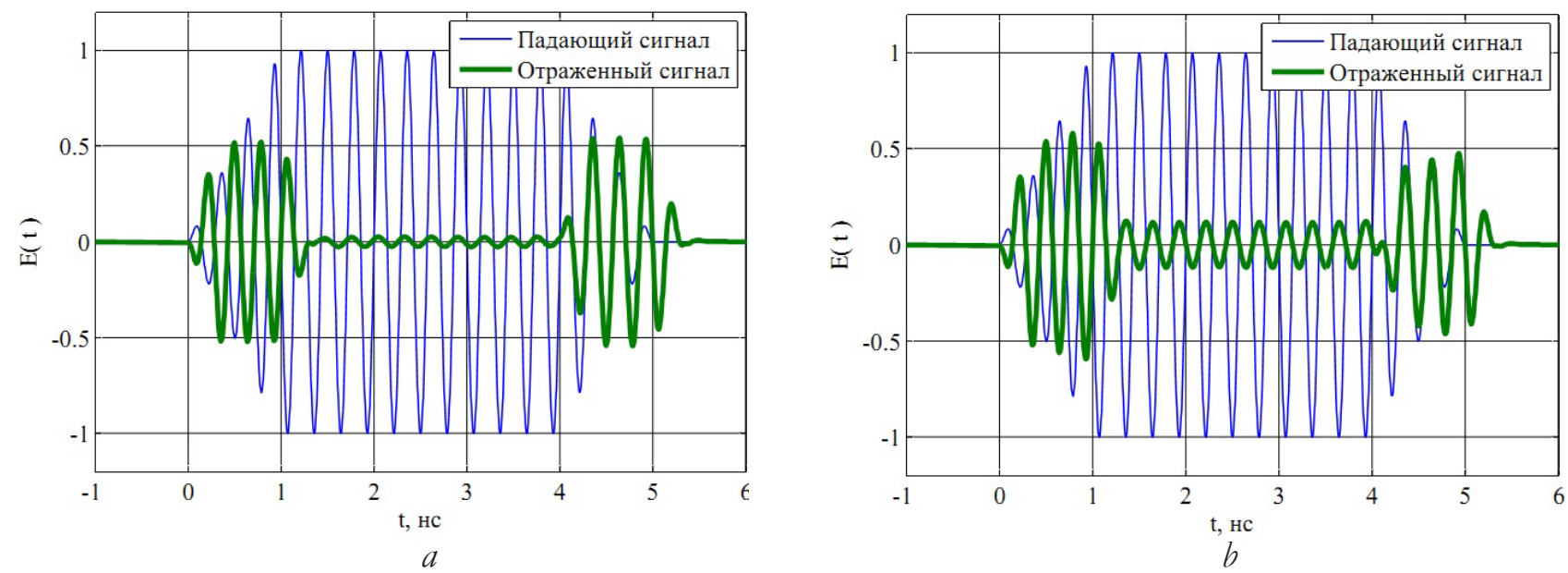

Рис. 4. Отраженные и падаточие сигналь, рассчитанньге методом конечных разностей во временной области, для случаев:

а) отутствия потерв в полуволновом слое, $(\varepsilon=2+0.0 i)$; b) наличия потерв в полуволновом слое, $(\varepsilon=2+0.05 i)$.

свободного пространства между генератором и слоем Аиэлектрика, которое Аолжна преодолеть волна, прежде чем отразиться. В случае метода конечных разностей это - расстояние межАу плоскостью, на которой заданы начальные значения поля $E(t)$, и Аиэлектрическим слоем. Как правило, оно составцяет не менее 10 пространственных ячеек сетки, на которой производится расчет. Наличие описанного участка свободного пространства приводит к возникновению дополнительного набега фаз, межАу отраженным и падающим сигнацами. Этот сАвиг фаз затрудняет анализ получаемых результатов, поэтому Аля наглядности на рис. 4 он скомпенсирован таким образом, что начало отраженного сигнала совмещено с началом падающего импульса.

Аля анализа влияния потерь на процесс нестационарного отражения расчет поля $E_{\mathrm{r}}(t)$ был проведен как с учетом потерь в полуволновом слое, так и без учета этих потерь. Во втором случае полагалось, что $\varepsilon "=0$. При отсутствии потерь (рис. 4a), согласно соотношению (19), слой явАяется неотражающей структурой. Поэтому в области постоянной амплитуды падающего импульса отраженный сигнал пренебрежимо мал. При этом импульсы, отраженные в области фронтов падающего сигнаца, имеют прямоугольную огибающую (рис. $4 a$ ).

Наличие Ааже небольших потерь в слое приводит к нарушению амплитудного баланса интерферирующих волн, в результате чего наблюдается появление отраженного сигнала в области постоянной ампАитуды падающего импульса, что видно на рис. 4b. При учете потерь, импульсы, сформированные в процессе нестационарного отражения в области фронтов падающего сигнала, изменяют свою форму по сравнению с импульсами Аля случая отсутствия потерь (рис. 4b). Импульс, сформированный в области переднего фронта, отличен от импульса в области заднего фронта, что не наблюдается на рис. 4a. Отраженный сигнал, как в случае наличия потерь в слое, так и в случае Аиэлектрического слоя без потерь, состоит из Авух импульсов, которые находятся в противофазе.

Обратим внимание на особенность в области заднего фронта падающего сигнала на рис. $4 b$. Несмотря на наличие потерь в момент отражения заднего фронта, существует момент времени, когда амплитуда отраженного сигнала стремится к нулю, а фаза отраженного сигнаца

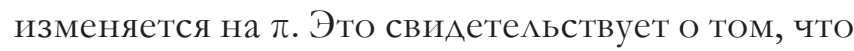
в Аанный момент выполняется условие баланса амплитуд интерферирующих в структуре волн.

Импульс с трапецеилальной огибающей явАяется удобной математической моделью Аля анализа процесса нестационарного отражения, но на практике такие сигналы применяются крайне редко. Это вызвано тем, что получение минейного фронта у сверхкороткого импульса явАяется достаточно сложной задачей. C Аругой стороны трапецеилальный импульс явАяется кусочнонепрерывной функцией, что накцадывает Аополнительные ограничения при попытке его экспериментацьной реацизации. 
Аیя практического применения намного чаще используются импульсы с гауссовой или супергауссовой огибающей. Поэтому наравне с трапецеилальными импульсами приведем результаты численного моделирования Аля гауссовых импульсов.

При моделировании амплитуда падающего сигнала $E_{i}(t)$ задавалась согласно следующей формуле:

$$
E_{i}(t)=e^{-\left(\frac{t_{0}-t}{\tau_{1}}\right)^{2 p}} \cdot \sin (\omega t),
$$

здесь $p$ - натуральное число, $\tau_{1}-$ масштабный множитель, определяющий Алительность импульса, $t_{0}$ - задает положение центра импульса на временной шкале, $\omega$ - нормированная круговая частота. На рис. 5 представцены результаты численного моделирования процесса нестационарного отражения от Аиэлектрического слоя с потерями Аля импульса с супергауссовой огибающей. Результаты были получены Аля значений $p=1$ (гауссов импульс)
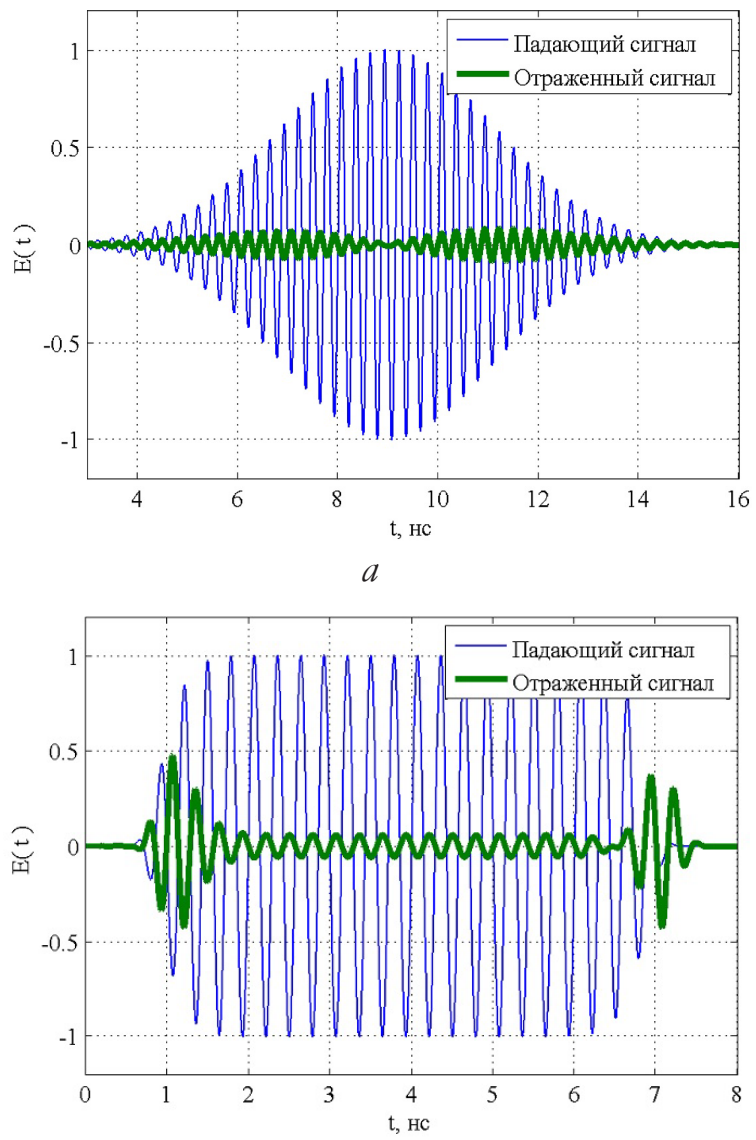

$c$ и $p=6$ (супергауссов импульс); $t_{0}=6.5, \tau_{1}=5$. Амплитуда отраженного сигнала на всех графиках увеличена в пять раз.

Из рис. 5 виАно, что все особенности формирования отраженного сигнала при наличии потерь в слое наблюдаются Аля импульсов с гауссовой и супергауссовой огибающей. Численный расчет методом конечных разностей во временной области позволиА получить зависимость амплитуды от времени Аля импульса, сформировавшегося в процессе нестационарного отражения от Аиэлектрической пластинки с потерями. Проведенный анализ результатов численного эксперимента позволил выявить ряА новых особенностей в формировании отраженного импульса, которые не наблюдались в случае отсутствия потерь.

Аля более Аетального анализа процесса нестационарного отражения в случае наличия потерь, получим аналитическое выражение Аля
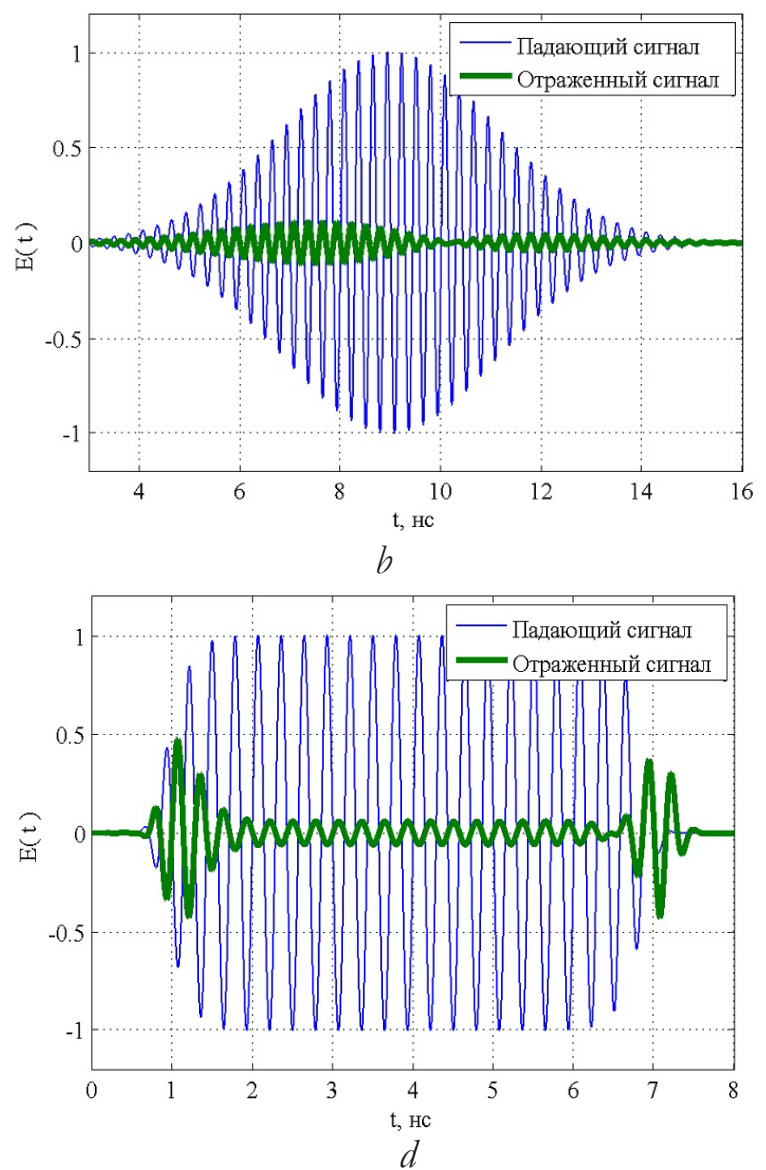

Рис. 5. Отраженные и паданочие сигнальг, расситанные методом конечных разностей для случая: а) отсутствия потерь в полуволновом слое $\varepsilon=2$, гауссовой формьг импульс; b) наличия потерь в полуволновом слое $\varepsilon=2+0.05 i$, импульс гауссовой формыг; с) опсутствия потерь в полуволновом слое $\varepsilon=2$, импульс супергауссовой формыг; d) наличия потерь в полуволновом слое $\varepsilon=2+0.05 i$, импульс супергауссовой формыл. 
отраженного

амплитуАно-модулированного сигнаца.

Аля удобства Аальнейших вычислений перейлем к безразмерным еАиницам. Введем безразмерное время:

$$
t=t^{\prime} / \tau_{0}
$$

здесь $\tau_{0}-$ задает масштаб временной шкалы, $t^{\prime}-$ время в секундах. Аля ампиитуды отраженного сигнала, без учета возможных потерь, в работах [35, 36] было предложено аналитическое решение виАа:

$$
U(t)=\frac{r_{0}}{1-r_{0}^{2}}[A(t)-A(t-\Delta t)] e^{i \omega t},
$$

зАесь $\omega-$ круговая частота сигнала в безразмерных единицах, $r_{0}$ - френелевский коэффициент отражения, через $A(t)$ - обозначена зависимость нормированной амплитуды паАающего сигнала от времени, $\Delta t-$ удвоенное время прохожАения волной пАенки.

Аанный результат был получен Аля амплитудно-модулированного сигнала, отраженного от просветляющей четвертьволновой пленки, без учета возможных потерь в ней. Выражение (22) также справедливо Аля пленок кратной толщины. При выводе использовался метоА прямого суммирования интерферирующих в пленке волн и приближение меАленно меняющихся амплитуА. Из формулы (22) виАно, что отраженный сигнал яв яется суммой Авух противофазных сигналов. Такое представление очень удобно Аля анациза процесса формирования отраженного сигнала.

Учет малых потерь, как было показано выше, приводит к изменению только амплитудных характеристик интерферирующих в слое волн. Применяя тот же подхоА, что и в работе [17], после несложных вычислений, можно получить Аля полуволнового слоя с потерями решение слеАующего виАа:

$$
U(t)=\frac{r_{0}}{1-r_{0}^{2}}[A(t)-A(t-\Delta t) K] e^{i \omega t},
$$

зАесь коэффициент $K$ характеризует потери энергии при распространении волны внутри слоя.

$$
K=\mathrm{e}^{-2 \alpha d} \text {. }
$$

Напомним, что $\alpha-$ действительная часть постоянной распространения (9), $d$ - толщина пластинки.
Проанализируем процесс формирования отраженного сигнала с помощью полученного выражения (22) на примере сигнала с трапецеилальной огибающей. Пусть трапецеилальный сигнац имеет Алительность $\tau$, а тангенс угла наклона его фронтов равен по модулю числу $k=1 / s, s-$ Алительность фронтов (рис. 6). Пусть Алительность сигнала $\tau$ и Алительность фронтов $s$ много больше периода несущей частоты. Обозначим амплитуду огибающей сигнала как:

$$
A(t)=\left\{\begin{array}{ll}
k t, & t_{1} \leq t<t_{3} \\
1, & t_{3} \leq t<t_{5} \\
k(\tau-t), & t_{5} \leq t<t_{8}
\end{array} .\right.
$$

В Аальнейшем изложении амплитуду огибающей будем просто называть амплитудой, опуская слово "огибающая"Аля краткости.

Учитывая, что время $\Delta t$ мало относительно Алительности сигнала $\tau$, разложим второе слагаемое в формуле (23) в рял:

$A(t-\Delta t)=A(t)-\frac{d A}{d t} \Delta t$.

Огибающая отраженного сигнаца примет слеАующий виА:

$U(t)=\frac{r_{0}}{1-r_{0}^{2}}\left[A(t)-A(t) K+\frac{d A}{d t} \Delta t\right]$.

Аля удобства анализа условно разделим Алительность падающего сигнала на несколько интервалов. На рис. 6 представлены $A(t)$ и $A(t-\Delta t)$ и их разность. На интерваце времени

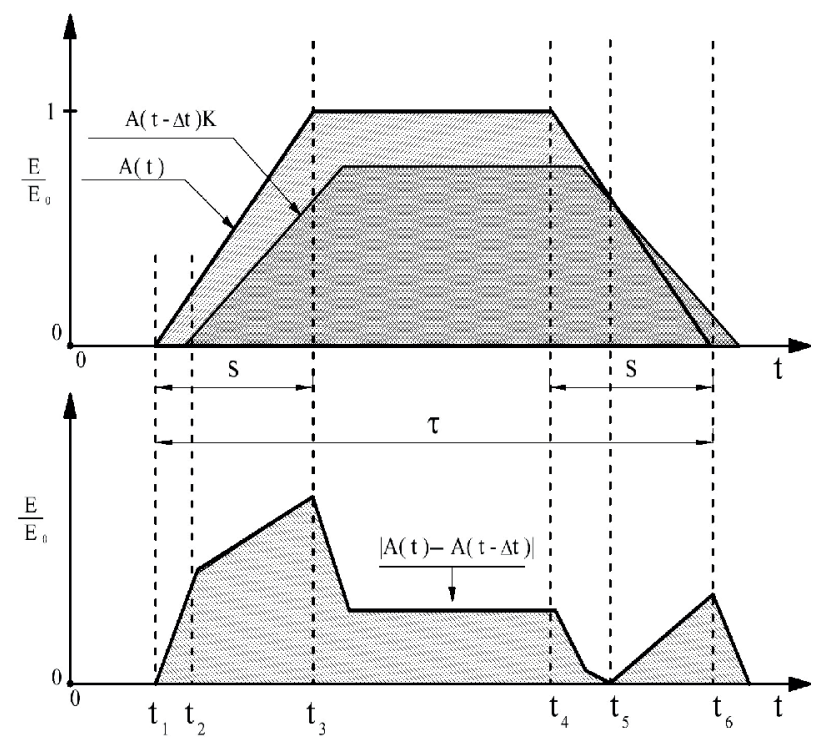

Рис. 6. Обозначения для расчета амплитудьг отраженного сигнала. 
от $t_{1}$ Ао $t_{2}$ происходит френелевское отражение сигнала. Интервац времени от $t_{1}$ Ао $t_{2}$ равен удвоенному времени прохожАения сигнала в Аиэлектрическом слое:

$\left|t_{1}-t_{2}\right|=\frac{2 d \sqrt{\Lambda_{1}}}{c}$.

На интервале времени от $t_{2}$ АO $t_{3}$ А^я огибающей отраженного сигнаца получаем:

$$
U(t)=\frac{r_{0}}{1-r_{0}^{2}}[k t(1-K)+k K \Delta t] .
$$

Тогда Аля тангенса угла наклона огибающей отраженного сигнала - k', на рассматриваемом интервале, получим:

$$
k^{\prime}=\frac{r_{0}}{1-r_{0}^{2}}(1-K) k \text {. }
$$

Заметим, что тангенс угла наклона фронтов отраженного сигнала не зависит от Алительности фронта падающего сигнала. На интервале времени от $t_{3}$ Ао $t_{4}$ имеем: $d A / d t=0$, следовательно:

$$
U(t)=\frac{r_{0}}{1-r_{0}^{2}}[A(t)(1-K)],
$$

учитывая, что $A(t)=E_{0}$, получаем:

$$
U(t)=\frac{r_{0}}{1-r_{0}^{2}}(1-K) E_{0} .
$$

В частном случае, отсутствия потерь в слое, выражение (32) дает известный результат: $U(t)=0$.

На интервале времени от $t_{4}$ Ао $t_{6}$ выполняется условие:

$$
d A / d t<0 \text {. }
$$

Из рис. 6 виАно, что всегАа существует момент времени $t_{\text {min, }}$, когАа,

$A\left(t_{\text {min }}\right)=A\left(t_{\text {min }}-\Delta t\right)$,

a амплитуда отраженного сигнала (23) имеет цокальный минимум. Важно отметить, что функция $A(t)$ не является непрерывной, и зависимости от времени $A(t)$ и $A(t-\Delta t)$ могут не совпадать. Например, на рассматриваемом интервале времени от $t_{4}$ Ао $t_{6}$ возможны Ава варианта:

$$
\begin{aligned}
& A(t)=\frac{\tau-t}{s}, A(t-\Delta t)=1 ; \\
& A(t)=\frac{\tau-t}{s}, A(t-\Delta t)=\frac{\tau-t+\Delta t}{s} ;
\end{aligned}
$$

второй вариант изображен на рис. 6 .

Выясним, при каком значении времени $t_{\min }$ Аостигается минимум отражения ААя этих Авух случаев. Напомним, что Аанный минимум амплитуды отраженного сигнала наблюдался нами при численном моделировании методом конечных разностей (см. рис. 4). В первом случае имеем:

$$
\frac{\tau-t_{\min }}{s}-K=0, t_{\min }=\tau-K s .
$$

Полученное соотношение верно только ААя времени $\tau-s<\mathrm{t}_{5}<\tau-K s$. А^я второго случая, подстав яяя в явном виде выражения Аля амплитуды заАнего фронта падающего сигнаАа в (36), получим:

$$
A(t)=\frac{\tau-t}{s}, \frac{d A}{d t}=-k \text {. }
$$

Тогаа:

$$
t_{\min }=\tau-\frac{s K k \Delta t}{1-K} .
$$

Из проведенного анализа вилно, что полученное аналитическое выражение (23) позволяет с высокой точностью рассчитать амплитуду отраженного сигнала, не обращаясь к численным методам. Также проведенный анализ показывает на возможность определения Аиэлектрических характеристик слоя путем измерения параметров отраженного импульса.

\section{2. ОТРАЖЕНИЕ ОТ САОЕВ $N \lambda / 2$}

Численное моделирование процесса нестационарного отражения амплитудномодулированного сигнала показало, что интенсивность отраженного сигнаца составцяет всего несколько процентов от интенсивности падающего. При практическом применении

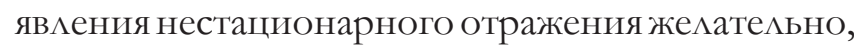
чтобы амплитуда сформировавшихся в результате нестационарного отражения импульсов была максимальной, при условии, что коэффициент отражения структуры на несущей частоте импульса остается близким к нулю.

В формулу (23) входят Ава параметра: коэффициент отражения $r_{0}$ и удвоенное время $\Delta t$ распространения волны через слой. Изменение каждого из этих параметров приводит к изменению амплитуды отраженного сигнала. Проанализируем возможность усиления явления нестационарного отражения за счет изменения этих параметров.

Из формулы (23) вилно, что увеличение $r_{0}$ приведет к усилению явления нестационарного отражения. Френелевский коэффициент отражения $r_{0}$ задается Аиэлектрическими 
свойствами вещества, из которого изготовлена пластинка. Отсюда следует, что применение Аиэлектриков с высокими значениями относительной Аиэлектрической проницаемости и низкими потерями ААя изготов ения полуволнового слоя позволяет усилить эффект нестационарного отражения. К сожалению, веществ с низкими потерями и большим показателем преломления крайне мало. ЗаАача усимения эффективного показателя на границе межАу полуволновой пластинкой и свободным пространством или волновеАущей минией может быть решена за счет установки пластинки межАу многослойными зеркалами [38].

Перейлем теперь к анализу возможности усиления явления нестационарного отражения за счет изменения времени распространения волны в Аиэлектрическом слое.

Из выражения (23) виАно, что амплитуду отраженного сигнала можно увеличить за счет увеличения времени распространения сигнаца в структуре. Аействительно, время прохожления волны через слой входит в выражение Аля огибающей, а амплитуда отраженных импульсов напрямую зависит от этого времени.

Если рассмотреть процесс нестационарного отражения от слоя толщиной кратной $\lambda / 2$, т.е. $d=N \lambda / 2$, например, при $N>3$, то вклаА, обусловленный временем прохожления может стать заметным. Это мегко объясняется тем, что разность $A(t)-A(t+\Delta t)$, входящая в формулу (23), возрастает.

Из (22) Аля минейно нарастающего фронта следует, что увеличение толщины пластинки в два раза приведет к такому же увеличению амплитуды отраженного сигнала. Аля пластинки толщиной $\lambda$ формула (23) примет виА:

$$
U(t)=\frac{2 r_{0}}{1-r_{0}^{2}}\left[A(t)-A(t-\Delta t) K_{2}\right] e^{i \omega t},
$$

зАесь множитель $K_{2}$ характеризует потери в слое.

Амплитуда отраженного импульса зависит от разности Авух сигналов. При увеличении времени залержки между волнами, отраженными от передней и задней граней пластинки, эта разность возрастает. Максимальная амплитуда импульса будет достигнута при времени задержки, равном Алительности фронта. Аальнейшее увеличение времени распространения не приведет к увеличению амплитуды отраженного сигнала, так как амплитуда первого слагаемого в выражении (23) не будет увеличиваться.

На рис. 7 представлены результаты численного модеАирования в иияния толщины Аиэлектрического слоя на амплитуду отраженного сигнаца. Аля наглядности амплитуда отраженных сигналов увеличена в 10 раз. Толщина слоя изменялась кратно $\lambda / 2$. Моделирование проводилось методом импедансных характеристик с последующим применением обратного преобразования Фурье. Результаты приведены ААя толщины Аиэлектрического слоя От $\lambda$ АО $6 \lambda$. В качестве материаца Аля слоя был взят Аиэлектрик с относительной Аиэлектрической проницаемостью равной $\varepsilon=2+0.01 i$. Расчет проводился без учета волноводной Аисперсии.

Исходные данные расчета были таковы, что на диэлектрическую пластинку паАал импульс с трапецеилальной огибающей. Несущая частота соответствова^а частоте минимального отражения. При увеличении толщины слоя в кратное число раз частота нулевого отражения не изменяется.

Как виАно из графиков рис. 7, при увеличении толщины слоя Алительность отраженных импульсов возрастает, как и было предсказано. При постоянной амплитуде падающего сигнала амплитуда отраженного сигнала Аолжна быть минимальна, в противном случае структура перестанет быть неотражающей. Как виАно из рис. 7, это

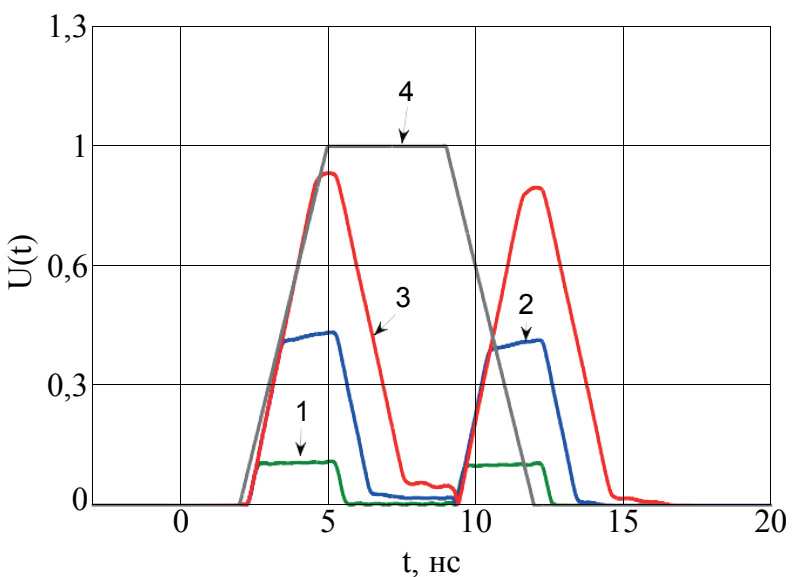

Рис. 7. Огибатошие отраженного сигнала ири разной оптической толщине диэлектрического слоя: 1 - толщина слоя $d=\lambda ; 2-$ толшина слоя $d=4 \lambda ; 3-$ толшина слоя $d=8 \lambda ; 4-$ паданоий сигнал. 
требование выполнено Аля слоев с толщиной от $\lambda / 2$ Ао $2 \lambda$ и частично Аля слоев $4 \lambda$ и $8 \lambda$. Аля слоя толщиной $8 \lambda$ амплитуда отраженного сигнаца успевает Аостигнуть своего максимума только в тот момент, когАа амплитуда падающего сигнала становится постоянной. В этом случае наблюдается изменение формы отраженного сигнала, а также его Алительности.

Проведенный анализ показац, что Аля увеличения интенсивности импульсов, сформированных в процессе нестационарного отражения АМ сигнала, есть несколько возможностей.

Во-первых, можно уменьшать Алительность фронта падающего на структуру импульса; во-вторых, увеличивать время прохождения импульса через слой. C Аругой стороны, важно помнить, что увеличение толщины слоя приводит К кратному увеличению потерь энергии в нем. Как было показано выше, увеличение потерь негативно сказывается на явцении нестационарного отражения за счет подав ения интерферирующих в слое волн.

\section{3. ВАИЯНИЕ ВОАНОВОАНОЙ АИСПЕРСИИ}

При экспериментальном исследовании процесса нестационарного отражения удобно использовать многослойные структуры, собранные в волноводном тракте. Такой подход позволяет зафиксировать слои многослойной структуры на требуемом расстоянии Аруг от Аруга с высокой точностью. При этом необходимо учитывать вАияние волноводной Аисперсии на процесс нестационарного отражения.

Проведем теоретический анализ вАияния волноводной Аисперсии на процесс нестационарного отражения амплитудномоАулированных сигналов. А^я этого рассмотрим полуволновой слой, установ енный в регулярном волноводе прямоугольного сечения. Пусть в волноводе возбуждена основная мода $H_{10}$. Запишем закон дисперсии через зависимость Алины волны в свободном волноводе от частоты. А^я моды $H_{10}$ получаем:

$$
\lambda=\frac{\frac{c}{v}}{\sqrt{1-\left(\frac{v_{c_{0}}}{v}\right)}}, \quad \text { при } \quad v \in\left(v_{c_{0}} ; v_{c_{1}}\right),
$$

здесь $c$ - скорость света в вакууме, $v$ - частота сигнала, $\nu_{c 0}-$ критическая частота Аля моды $H_{10}, \nu_{\text {c1 }}-$ критическая частота Аля моды $H_{01}$. Из соотношения виАно, что при $\nu \rightarrow \infty \lambda=c / \nu$ и вАиянием Аисперсии можно пренебречь. Как известно [38], в волноводе может одновременно сушествовать большое число моА, и при частоте $\nu>\nu_{\text {с2 }}$ произойдет возбуждение второй моды. ВозбужАение второй моды существенно повлияет на Аисперсионные характеристики волновода, усложнив анализ. Оптимальный интервац рабочих частот цежит примерно в Аиапазоне $1.25 \nu_{c}$ А $\nu_{c 1}$.

Аля анализа влияния Аисперсии нам необходима возможность изменять частоту несущего сигнала от области со слабой Аисперсией к области с сильной. А Аля этого необходимо, чтобы коэффициент отражения от слоя имел несколько минимумов в рассматриваемом диапазоне частот, так как несущая сигнала Аолжна совпадать с частотой минимального коэффициента отражения.

Рассмотрим процесс нестационарного отражения от с $А$ оя толщиной в $6 \lambda$ установ енного

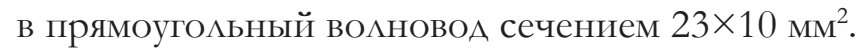
На рис. 8 представ ен коэффициент отражения от рассматриваемого слоя. Спектр был рассчитан методом импедансных характеристик.

Представленные на рис. 8 результаты говорят о том, что в области сильной Аисперсии коэффициент отражения возрастает. Также видно, что в рассматриваемом Аиапазоне существует несколько значений частот, при которых коэффициент отражения обращается в ноль.

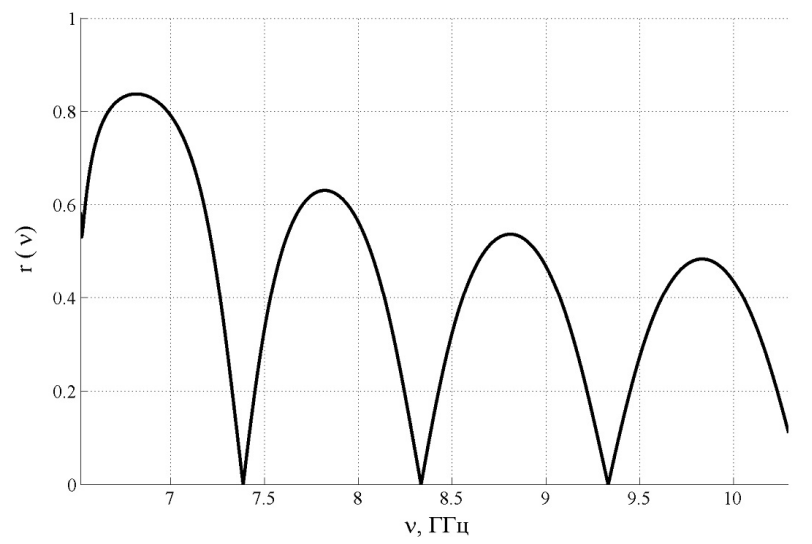

Рис. 8. Спектр отражения от диэлектрической пластинки толшиной $6 \lambda$ в волноводе. 
Аля частот, соответствующих нулевому отражению, произведем расчет огибающей отраженного сигнала. Пусть на слой паАает сигнал с трапецеилальной огибающей. Обозначим несущую частоту сигнала как $\nu_{0}$. Несущую частоту $\nu_{0}$ выразим в единицах относительно критической частоты $\nu_{c}$ ААя удобства анализа.

Из представленных результатов на рис. 9 виАно, что при наличии волноводной Аисперсии форма огибающего сигнала изменяется. При увеличении Аисперсии (при приближении к критической Алине волны) амплитуда отраженного сигнала возрастает, а его Алительность увеличивается. Также в области сильнойАисперсиипоявАяютсядополнительные осцилмяции амплитуды отраженного сигнала. Аегко заметить, что при частоте $\nu_{0}>1.25 v_{c}$ форма огибающей отраженного сигнала не изменяет своего характера. В отличие от рассмотренного в пункте 2.2 случая увеличения времени прохождения сигнаца через структуру, приближение к критической частоте не увеличивает потери в слое.

Подводя итог, можно сказать, что использование явления волноводной Аисперсии и увеличение кратности слоя позволяет увеличить амплитуду сигнала, сформированного в процессе нестационарного отражения. Увеличение толщины слоя приводит к увеличению потерь в многослойных структурах, что негативно сказывается на явлении нестационарного отражения. Использование волноводной Аисперсии

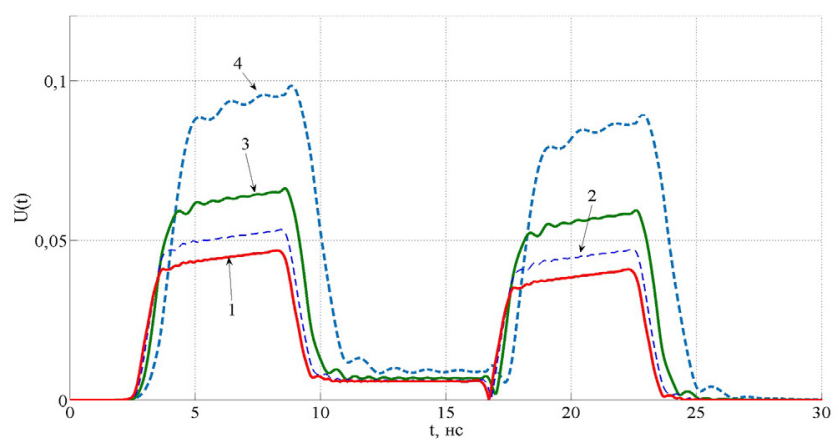

Рис. 9. Огибатошие отраженного сигналя при различныгх значениях несуших частот падатощего импульса, для случаев: 1) частота падатощего импульса $v_{0}=1.135 \mathrm{v}$; 2) частота падағощего импульса $v_{0}=1.128 \mathrm{v}$; 3) частота паданощего импульса $v_{0}=$ $1.143 v$; 4) yacmoma nадатощего импульса $v_{0}=1.159 \mathrm{v}$. позволяет более эффективно увеличивать амплитуду отраженного сигнала.

\section{4. ЭКСПЕРИМЕНТААЬНОЕ ИССАЕАОВАНИЕ ОТРАЖЕНИЯ СИГНААА ОТ ПОАУВОАНОВОГО ФИАьТРА}

Явление нестационарного отражения коротких электромагнитных импульсов от слоистых структур измерялось на стенде (рис. 10), который состоит из векторного анализатора цепей Rohde\&Schwarz ZVB-20 с подкАюченным к нему прямоугольным волноводом, в который помещалась слоистая структура, полностью заполняя его поперечное сечение. С одной стороны волновод возбужАался коаксиальноволноводным переходом (КВП) со штыревой антенной, с Аругой - подкАючалась согласованная волноводная нагрузка. Заявленный Аинамический Аиапазон Аля ZVB-20 составлял больше 125 АБ [39]. При калибровке его входного тракта использовались волноводные секции с нагружаемой нагрузкой. Паразитные переотражения, возникающие в волноведущей системе, были отфильтрованы во временной области стробированием с оконной функцией Ханна [40], используя обратное преобразование Фурье [41] калибровочного сигнала.

Предметом исследования являлся анализ огибающей отраженного от пластинки сигнала. Эксперимент проводился Аля пластинок, изготовленных из Аиэлектриков с разными значениями относительной Аиэлектрической проницаемости. В качестве материалов были выбраны: фторопласт-4, полиамил-6 (капролон), кварц марок КУ и КВ. Кварц и фторопласт-4 имеют низкие потери в микроволновом Аиапазоне Алин волн $\left(\operatorname{tg}(\delta)<10^{-3}\right)$. Капролон был выбран как материац, обладающий большими потерями, чем фторопласт-4 и кварц.

Измерялась зависимость комплексного коэффициента отражения от частоты $r(v)$.

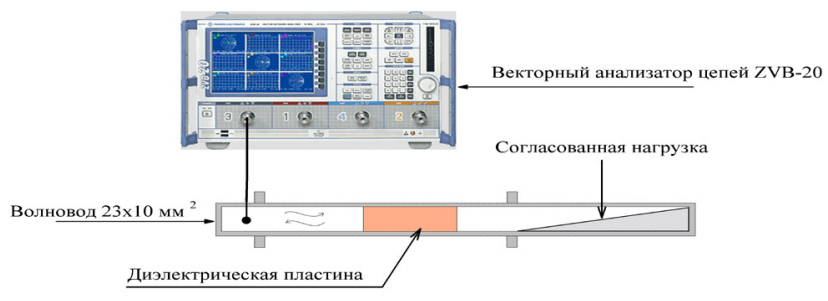

Рис. 10. Схема установки с однослойнвим фильтром. 
Измерения проводились в Аиапазоне частот от 6 ГГц Ао 14 ГГц, который перекрывает область частот существования моды $H_{10}$ Аля подКАюченного волновода сечением $23 \times 10$ мм $^{2}$.

Измеренный коэффициент отражения использовался при следующем расчете огибающей отраженного импульса малой Алительности. Пусть на многослойную структуру падает сигнал с трапецеилальной огибающей. Амплитуду сигнала можно записать в виде:

$E(t)=A(t) \cos (2 \pi \nu t)$,

где $\nu$ - несущая частота, а $A(t)$ задается соотношением

$$
A(t)= \begin{cases}\frac{t}{s}, & 0 \leq \mathrm{t}<\mathrm{s}, \\ 1, & \mathrm{~s} \leq \mathrm{t}<(\tau-\mathrm{s}), \\ \frac{\tau-t}{s}, & (\tau-\mathrm{s}) \leq \mathrm{t}<\tau,\end{cases}
$$

здесь $s-$ Алительность фронта импульса, $\tau-$ Алительность импульса по уровню -10АБ.

Если известен коэффициент отражения от исслеАуемой многослойной структуры $r(v)$, то Аля расчета спектра отраженного сигнаца можно воспользоваться соотношением:

$H_{g}(v)=r(v) F(v)$.

Применив обратное преобразование Фурье к $H_{\mathrm{g}} \mathrm{v}$ по области положительных частот, получим аналитический сигнал:

$$
h(t)=\frac{1}{\pi} \int_{0}^{\infty} H_{g}(v) e^{i 2 \pi v t} d(2 \pi v) .
$$

Модуль аналитического сигнала $|\mathrm{h}(\nu)|$ явцяется искомой огибающей отраженного импульса. Таким образом, измеряя коэффициент отражения $r(v)$ в области положительных частот, можем получить огибающую отраженного импульса, а варьируя параметры $\nu, \Delta t, s$ можно изменять центральную частоту и Алительность паАающего сигна^а и его фронтов.

\subsection{1. ВАИЯНИЕ ПОТЕРЬ В САОЕ НА НЕСТАЦИОНАРНОЕ ОТРАЖЕНИЕ}

При нестационарном отражении электромагнитных импульсов малой Алительности от многослойных структур неотражающего типа существенную роль играют потери в слоях структур. А^я экспериментального исследования вАияния потерь в слоях на процесс нестационарного отражения было выбрано несколько материалов. В качестве Аиэлектриков с малыми потерями был выбран достаточно часто используемые в микроволновой технике материал - фторопласт-4. А как материал с относительно высокими потерями был выбран полиамиА-6.

Аля проведения измерений полуволновой слой устанавливался в середину свободного

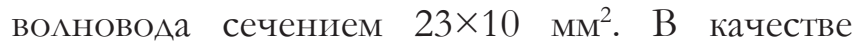
палающего сигнала использовался трапецеидальный электромагнитный импульс Алительностью 20 нс, Алительность переднего и заднего фронтов которого состав яла 7 нс. На рис. 11 пунктирными миниями преАставлены экспериментально полученные огибающие отраженного сигнала Аля полуволновых слоев, изготовленных из полиамида и фторопласта. А^я наглядности показана огибающая падающего импульса, уменьшенная в 10 раз.

Также на рис. 11 приведены результаты теоретического расчета. Теоретические кривые были получены методом импедансных характеристик с последующим применением обратного преобразования Фурье. При расчете использовались следующие значения Аиэлектрической проницаемости: полиамиА-6 $\varepsilon=2.98+0.037 i$, фторопласт-4 $\varepsilon=2.03+0.003 i$.

Как видно из рис. 11, результаты теоретического расчета хорошо согласуются с экспериментальными Аанными. Сравнивая результаты, полученные Аля фторопласта и

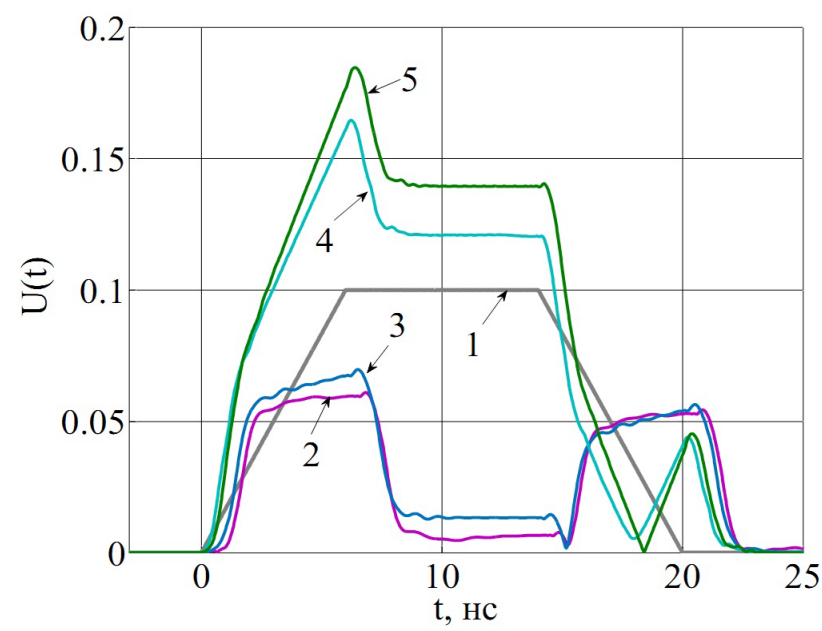

Рис. 11. Огибатошая отраженного сигнала: 1 - падаюошии сигнал; 2- экспериментальная кривая для слоя из фторопласта; 3 - теоретическая кривая для слоя из фторопласта; 4 - экспериментальная кривая для слоя из полиамида; 5 теоретическая кривая для слоя из полиамида. 
полиамиАа, видим, что огибающие отраженного сигнала в этих Авух случаях существенно отАичаются.

В случае материала с малыми потерями (фторопласт) виАно, что отраженный сигнац в области постоянной амплитуды падающего импульса практически отсутствует. Отраженный сигнал состоит из Авух уединенных импульсов. Наличие малых потерь приводит к тому, что амплитуда этих импульсов различна, а форма огибающих этих импульсов отАичается от прямоугольной. Аанный результат показывает, что, Ааже при наличии малых потерь в слоях структуры, необходимо их учитывать.

При увеличении потерь в материале, сильно возрастает амплитуда отраженного сигнала в области постоянной амплитуды падающего импульса. При увеличении мнимой части относительной Аиэлектрической проницаемости возрастает разАичие импульсов, сформированных при отражении от Аиэлектрического слоя переднего и заднего фронтов падающего сигнала. На рис. 11 хорошо виАно, что Ааже при наличии потерь в полуволновом слое существует момент времени, когда амплитуда отраженного сигнала близка к нулю.

\subsection{2. ВАИЯНИЕ ТОАЩИНЫ САОЯ НА НЕСТАЦИОНАРНОЕ ОТРАЖЕНИЕ}

На амплитуду отраженного от Аиэлектрического слоя с потерями сигнала влияет время установления стационарного процесса в слое. При возрастании этого времени происходит увеличение интенсивности отраженного сигнала. А^я экспериментального исследования вАияния оптической толщины Аиэлектрической пластинки на процесс нестационарного отражения амплитудно-модулированного сигнала использовались три образца, изготовленные из фторопласта. Толщина образцов составцяла 30 мм, 60 мм, 90 мм. Образцы устанавливались в прямоугольный волновод, полностью заполняя его поперечное сечение. Аля частоты $\nu=8.4$ ГГц в еАиницах Алины волны слои имели толщину $\lambda, 2 \lambda, 3 \lambda$, соответственно. В эксперименте на слой падал электромагнитный импульс с трапецеилальной огибающей Алительностью 10 нс. Алительность

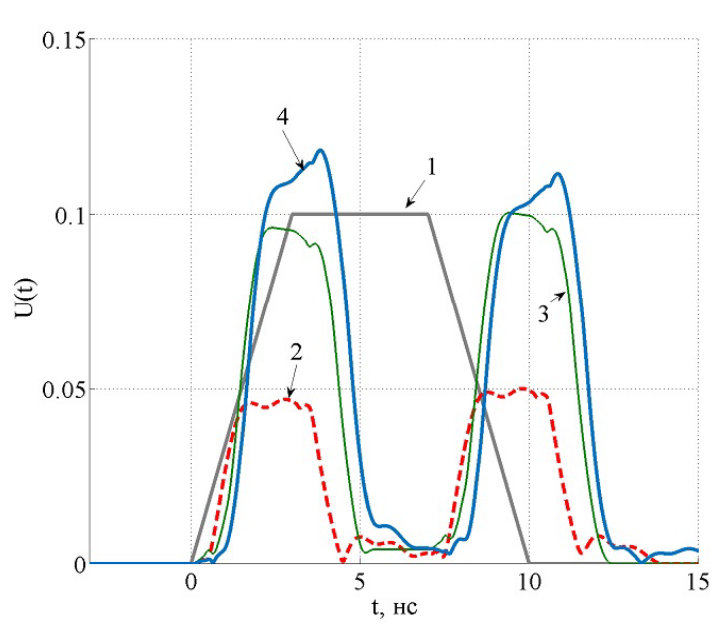

Рис. 12. Импульсьи, отраженнызе от слоев различной толщинь: 1 - падаюоиии сигнал, $2-$ толиина слоя $d=\lambda$; 3 - толиина слоя $d=2 \lambda ; 4-$ полиина слоя $d=3 \lambda$. фронтов импульса состав яла 3 нс. Центральная частота импульса $\nu=8.4$ ГГц. На рис. 12 представлены экспериментально полученные огибающие отраженного сигнаца.

Аля наглядности показана огибающая паАающего сигнала, уменьшенная в 10 раз. Из представленных результатов на рис. 12 виАно, что увеличение толщины слоя с $d=\lambda$ Ао $d=2 \lambda$ приводит к возрастанию амплитуды отраженного сигнала в Ава раза (40). С Аругой стороны, Аальнейшее увеличение толщины слоя от $2 \lambda$ Ао $3 \lambda$ не приводит к значительному увеличению амплитуды отраженного сигнала и искажает форму огибающей в области фронтов паАающего импульса. Это объясняется тем, что в этом случае Алительность фронта падающего сигнала становится уже сравнимой со временем прохожАения волной слоя.

\subsection{3. ВАИЯНИЕ ВОАНОВОАНОЙ АИСПЕРСИИ НА НЕСТАЦИОНАРНОЕ ОТРАЖЕНИЕ}

При экспериментальном исследовании процесса нестационарного отражения удобно использовать многослойные структуры, собранные в волноводном тракте. Такой подход позволяет зафиксировать слои многослойной структуры на требуемом расстоянии Аруг от Аруга с высокой точностью. При этом возникает необходимость учета вАияния волноводной Аисперсии на процесс нестационарного отражения. 
ОАним из способов анализа влияния Аисперсии на процесс нестационарного отражения, яв^яется изменение несущей частоты сигнаца от области со слабой Аисперсией к области с сильной дисперсией. Так как несущая частота сигнала Аолжна совпадать с частотой минимального коэффициента отражения МИС, необходимо, чтобы коэффициент отражения от слоя имел несколько минимумов в рассматриваемом диапазоне частот.

Рассмотрим процесс нестационарного

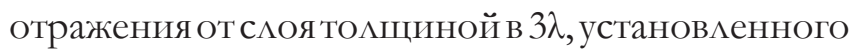
в прямоугольный волновод сечением $23 \times 10$ мм $^{2}$. Волновод указанного сечения имеет частоту отсечки $\nu_{\text {c }} \approx 6.5$ ГГц. В Аиапазоне частот от $\nu_{\text {с }}$ и АО частоты $\nu_{\text {с2 }} \approx 14.4$ ГГц в нем возбуждена только основная мода $H_{10}$. Волноводы такого сечения применяются, как правило, Аля Аиапазона частот от 8 до 12 ГГц. Это вызвано тем, что в областях 6.5-8 ГГц существенно влияние Аисперсии на процесс распространения электромагнитной волны в волноводе, а в области 12-14.5 ГГц возможно возбуждение АОПОАнитеАьной ВОАновОАной мОАЫ. Возбуждение высшей моды существенно влияет на Аисперсионные характеристики, приводя к сильным осцилцяциям коэффициента передачи волновода. Осцицияции коэффициента передачи вызывают дополнительные трудности при решении прикладных задач.

На рис. 13 представлены результаты экспериментально измеренного спектра отражения тефцонового слоя толщиной 90 мм, а также теоретический расчет. Расчет был выполнен методом импедансных характеристик А^я значения $\varepsilon=2.03+0.003 i$. На частоте 8.4 ГГц,

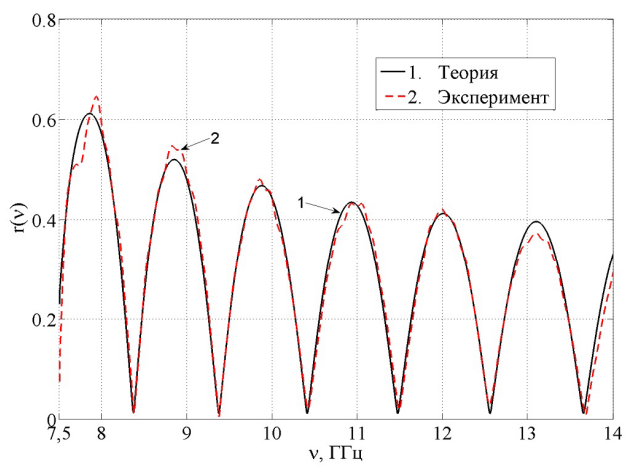

Рис. 13. Спектр отражения от тефлонового слоя: 1 - расчет методом импедансных характеристик; 2 - эксперимент. рассматриваемый Аиэлектрический слой имеет толщину $3 \lambda$.

На рис. 13 видно, что в начале и в конце частотного Аиапазона точность, предсказанная теорией, несколько ниже. Это вызвано тем, что согласованная нагрузка и коаксиальноволноводный переход предназначены Аля работы в Аиапазоне 8-12 ГГц. Вне этого Аиапазона частот качество согласования падает. Также видно, что в области симьной волноводной Аисперсии коэффициент отражения возрастает.

В рассматриваемом диапазоне существует несколько значений частоты, при которой коэффициент отражения обращается в ноль. Частоты минимума коэффициента отражения Аля рассматриваемого случая имели значения: 8.38 ГГц, 9.37 ГГц, 10.4 ГГц, 11.48 ГГц, 12.55 ГГц. Обратим внимание на то, что эти частоты не эквиАистантны. Аанный эффект объясняется наличием волноводной Аисперсии. Запишем закон Аисперсии через зависимость групповой скорости распространения электромагнитного импульса в волноводе от частоты. Аля моды $H_{10}$ получаем:

$V=\frac{c}{n} \sqrt{1-\left(\frac{v_{c}}{v}\right)^{2}}, \quad$ при $\quad v \in\left(v_{c}, v_{c 1}\right)$;

здесь $c$ - скорость света в вакууме, $v$ - частота сигнала, $\nu_{c}$ - критическая частота Аля моды $H_{10}$, $\nu_{c 1}$ - критическая частота Аля моды $H_{01}$, $n$ - показатель преломления вещества, заполняющего волновод. Из соотношения (46) виАно, что скорость распространения волны паАает при приближении $\nu$ к v с и слой становится как бы толще Аля падающей волны, что приводит к тому, что резонансы идут чаще, а ширина полосы пропускания сужается.

Аля частот, соответствующих нулевому отражению, произведем экспериментальное измерение огибающей отраженного сигнаца. Как и в случае исследования влияния толщины слоя на процесс нестационарного отражения, воспользуемся импульсом с трапецеилальной огибающей Алительностью 10 нс, с Алительностью фронтов 3 нс. Несущую частоту $\nu$ выразим в еАиницах относительно критической

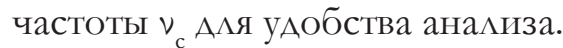




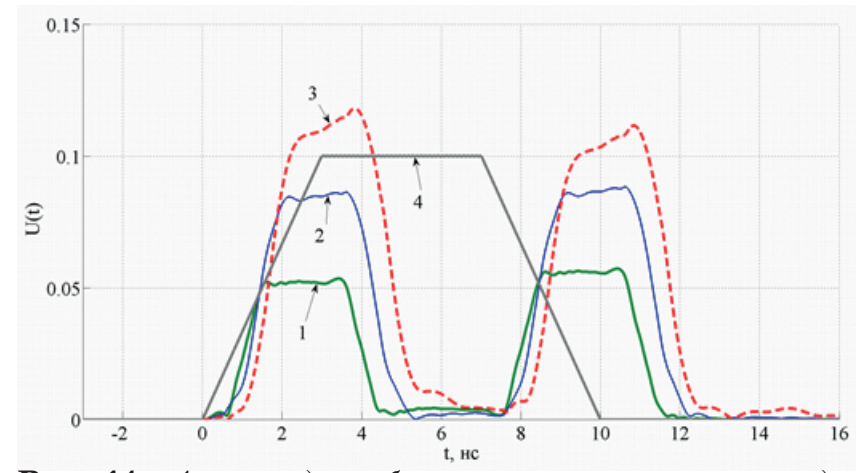

Рис. 14. Алплитуда огибатощей отраженныгх сигналов для разного значения несущей частотьг импульса: 1 - частота падапощего импульса $v=1.92 v_{c} ; 2$ - частота падаюмего импульса $v=1.44 v_{c} ; 3$ - частота паданощего импульса $v=1.29 v_{c} ; 4-$ паданоший импульс.

На рис. 14 показаны огибающие отраженных от фторопластовой пластинки сигналов, ААя разАичных значений несущей частоты. Аополнительно на графике рис. 14 показана огибающая падающего сигнала, уменьшенная в 10 раз. Из представленных результатов на рис. 14 виАно, что при наличии волноводной Аисперсии форма огибающей сигнала изменяет свой виА. При увеличении Аисперсии (при приближении к критической Алине волны $\nu \rightarrow v_{c}$ ) амплитуда отраженного сигнала возрастает, а его Алительность увеличивается. Также в области сицьной Аисперсии появАяются Аополнительные осциляяции амплитуды отраженного сигнаца. Аегко заметить, что при частоте $\nu>1.44 \nu_{\text {c }}$ форма огибающей отраженного сигнаца не изменяет своего характера. В отличие от рассмотренного выше случая увеличения времени прохождения сигнала через структуру, приближение к критической частоте не увеличивает потери в cлое.

\section{3. НЕСТАЦИОНАРНОЕ ОТРАЖЕНИЕ В УСАОВИЯХ СИАЬНОЙ ВОАНОВОАНОЙ АИСПЕРСИИ}

А^я усиления нестационарного отражения - увеличения Алительности импульса и его интенсивности, использовались Аисперсионные свойства волновеАущей Аинии при введении в волновоА высокоотражающей нагрузки из графита с согласующим слоем Аиэлектрика (тефцон) с малыми потерями (рис. 15). К волноводу сечением $23 \times 10$ мм $^{2}$ через плавный волноводный перехоА поАКАючался волновоА

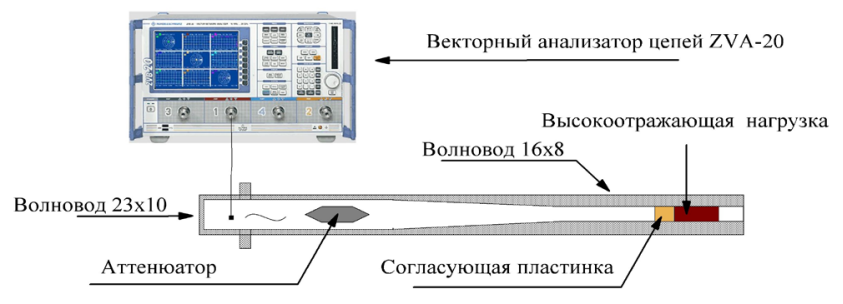

Рис. 15. Схема установки с въгокоотражсатощей нагрузкой. сечением $16 \times 8$ мм $^{2}$ Аля снижения вАияния эффектов, связанных с возбуждением волновода на частотах, близких к критическим. Рабочий Аиапазон частот используемого КВП состав $А$ К от 8.15 ГГц Ао 12.05 ГГц, а частоты, на которых проводились измерения - от 8.5 ГГц до 12 ГГц. Аля частичного подавления паразитных переотражений в волноводный тракт был введен аттенюатор с малым коэффициентом ослабления $k \approx 1.5$ АБ. Применение аттенюатора позволило существенно повысить точность получаемых значений амплитуды коэффициента отражения от согласованной высокоотражающей нагрузки, при этом затруднив измерение его фазы. Измерительный стенА позволял получать зависимость комплексного коэффициента отражения от частоты.

Эксперимент приводился в два этапа. На первом этапе измерялся коэффициент отражения от высокоотражающей нагрузки и рассчитывалась ее эффективная проводимость, a также измерялась критическая частота волновода. Полученные данные использовацись Аля расчета толщины согласующего слоя. На втором этапе, опираясь на результаты расчета, изготав иивалась серия Аиэлектрических слоев. Аалее проводились измерения коэффициента отражения от согласованной системы Аля слоев различной толщины. Таким образом, экспериментально подбиралась оптимальная толщина согласующего слоя.

Результаты, полученные на первом этапе показали, что эффективная проводимость нагрузки $\sigma \approx 130\left(\mathrm{OM}^{\cdot} \mathrm{M}\right)^{-1}$, критическая частота $\nu_{c}=9.339$ ГГц. Аля Аанной проводимости и известной критической частоты была рассчитана толщина согласующего слоя, которая составила $d=7.715$ мм. При измерении коэффициента отражения от системы с согласующим слоем минимальный коэффициент отражения был получен Аля частоты $\nu=9.383$ ГГц и 


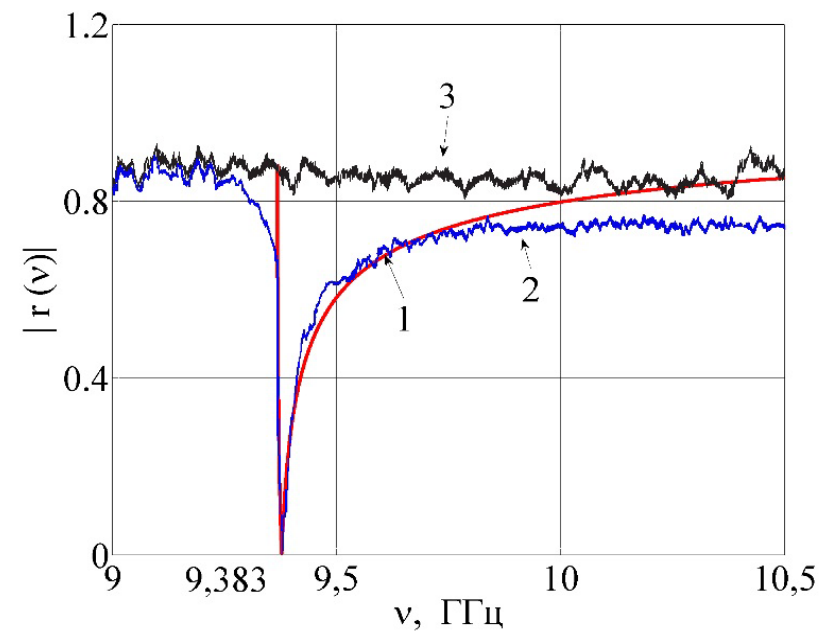

Рис. 16. Зависимость коэффичиента отражения от частотьг для согласованной нагрузки: 1 - расчет методом импедансньгх характеристик; 2-экспериментально измеренныгйкоэффичиент отражения от согласованной выгсокоотражаточей нагрузки; 3 экспериментально измеренный коэффичиент отражения от выгскоотражатошей нагрузки без согласуюшего слоя.

толщины слоя 8 мм, что хорошо согласуется с теоретически рассчитанными значениями.

На рис. 16 представлены результаты измерения зависимости коэффициента отражения от частоты Аля согласованной высокотражающей нагрузки и результат численного моделирования.

Как видно из рис. 16, результаты теоретического расчета хорошо согласуются с Аанными полученными в эксперименте. Рассмотренный метод согласования высокоотражающих нагрузок с волновеАущей Аинией представАяет собой простую, компактную и мегко реализуемую МИС. Предложенная согласующая структура имеет существенное

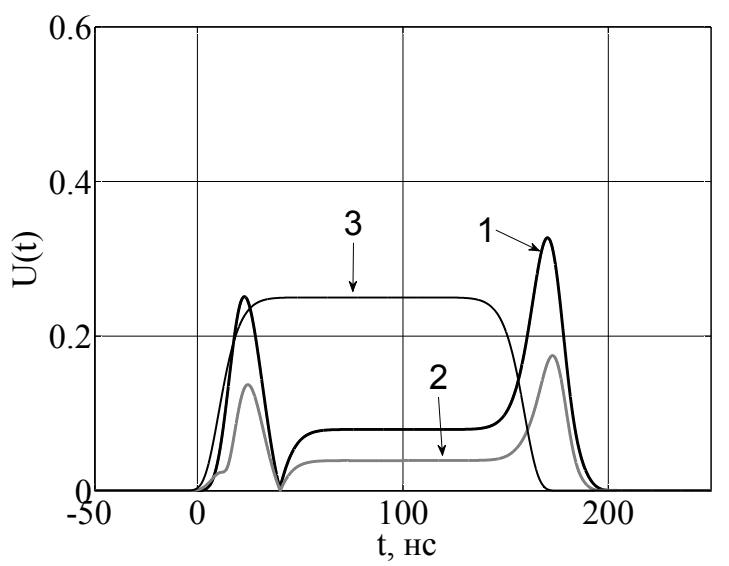

преимущество переА Аругими типами МИС: выбор материала Аля четвертьволнового Аиэлектрического слоя ограничивается практически мишь единственным требованием $\varepsilon_{l}<1 / Z_{\mathrm{s}}$. Конечно, при этом потери в слое, как и при Аюбом Аругом методе, Аолжны быть минимальны.

При исследования влияния сильной волноводной Аисперсии на процесс нестационарного отражения электромагнитного импульса от согласованной с волноводом высокоотражающей нагрузки аттенюатор, установленный межАу КВП и волноводной секцией с согласующей структурой, удалялся. В эксперименте измерялся комплексный коэффициент отражения от согласованной высокоотражающей нагрузки $r(v)$. В процессе эксперимента на слой падал электромагнитный импульс с супергауссовой огибающей. Алительность падающего импульса изменялась от 50 нс Ао 250 нс. Центральная частота импульса совпадаца с частотой оптимацьного согласования высокоотражающей нагрузки с волноводом $\nu=9.339$ ГГц. На рис. 17 представлены результаты теоретического моделирования и полученные в эксперименте огибающие отраженных импульсов, а также показана огибающая падающего сигнала, уменьшенная по оси $U$ в четыре раза Аля нагАяАности.

Как видно из рис. 17, результаты теоретического расчета хорошо согласуются с экспериментальными данными. Видно, что при уменьшении Алительности паАающего

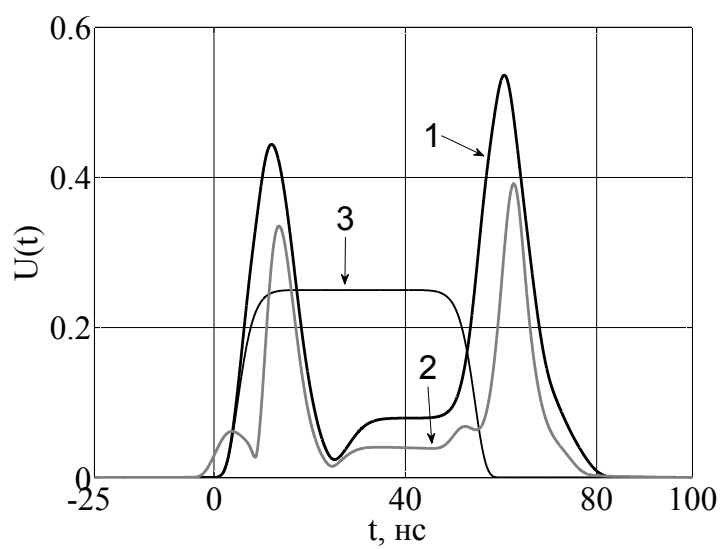

b

Рис. 17. Алплитудв огибатощих отраженныгх сигналов от согласованной всокоотражалощей нагрузки; а) длительность падатощего импульса 150 нс; б) длительность падаюоего импульса 50 нс.; 1 - теоретически рассчитанныгй отраженныгй сигнал; 2 - экспериментально измеренныцй отраженный сигнал; 3 - падаюочии импульс. 
импульса «искажение» отраженного импульса увеличивается, что можно объяснить вАиянием сильной волноводной Аисперсии. Как и в случае нестационарного отражения от систем без Аисперсии $[17,23,42]$, при отражении сигнала от рассмотренной структуры образуются Ава импульса в области переднего и заАнего фронтов. Сравнивая полученные экспериментальные результаты с результатами А^я системы без Аисперсии [17, 23, 42], видим, что Алительность этих импульсов существенно выросла. Существует момент времени, когда амплитуда отраженного сигнаца стремится к нулю, однако он наступает при отражении переднего фронта, а не залнего, как в случае отсутствия Аисперсии, рассмотренном в разделе 2. Еще одной важной особенностью по сравнению с системами без дисперсии явАяется высокая интенсивность отраженных сигнацов. Из рис. 17 вилно, что максимальная амплитуда импульсов, сформированных в процессе нестационарного отражения, Аостигает величины $50 \%$ от амплитуды падающего сигнала. Напомним, что максимальное значение амплитуды отраженного сигнала, полученное в разделе 2, не превышало 15\% от амплитуды падающего импульса. Большая интенсивность отраженного сигнаца указывает на перспективность использования сильной волноводной Аисперсии Аһя усиления яв Аения нестационарного отражения. Проведенные исследования продемонстрировали принципиальную возможность обеспечить практически полное поглощение волновой энергии в симьноотражающей нагрузке, используя интерференционные явления в слоистых структурах и Аисперсионные свойства волновеАущей Аинии. В областях изменяющейся амплитуды падающего сигнала (область фронтов) в откиике формируются короткие импульсы, Алительность которых соответствует Алительности фронтов. В отличие от случая систем без Аисперсии импульсы отраженного сигнала, сформированные в момент отражения фронтов палающего сигнала, имеют различную амплитуду Аля переднего и заднего фронтов. Амплитуда первого импульса всегда меньше амплитуды импульса, сформированного задним фронтом, и их огибающая имеет более сложную форму.

\section{4. НЕСТАЦИОНАРНОЕ ОТРАЖЕНИЕ В МНОГОС ОЙНЫХ ИНТЕРФЕРЕНЦИОННЫХ ФИАЬТРАХ}

Нестационарное отражение импульсного сигнала малой Алительности в многослойной структуре неотражающего класса в отличие от отражения сигнала от одного слоя характеризуется более сложными частотными зависимостями от падающего сигнала, а также существенной зависимостью от потерь в слоях отражающей структуры.

В нашей работе [43] было показано, что оптимальным условием нестационарного

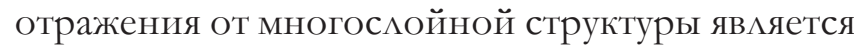
использование полосового фильтра второго порядка с максимально плоской амплитудночастотной характеристикой (АЧХ), хорошо известного в витературе, посвященной вопросам синтеза фильтров и просветляющих покрытий [44-46].

Простейшей реализацией многослойной структуры с максимацьно плоской АЧХ яв яется фильтр, состоящий из Авух резонаторов, межАу которыми реализована критическая связь $[45,47]$. Была использована структура, состоящая из двух полуволновых слоев Аиэлектрика без потерь, которые расположены в свободном пространстве Аруг за Аругом на расстоянии четверть Алины во нны (рис. 18).

При идеальной структуре фильтра отражение от слоистой структуры может быть рассчитано А^я сигнала, огибающая которого имеет симметричную трапецеилальную форму с минейными фронтами. Пусть полуволновые слои фильтра выполнены из Аиэлектрика с

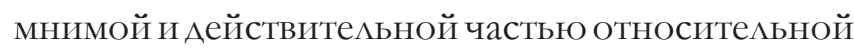
Аиэлектрической проницаемости, равными $\varepsilon^{\prime}=2, \varepsilon^{\prime \prime}=0.00$, соответственно. Будем

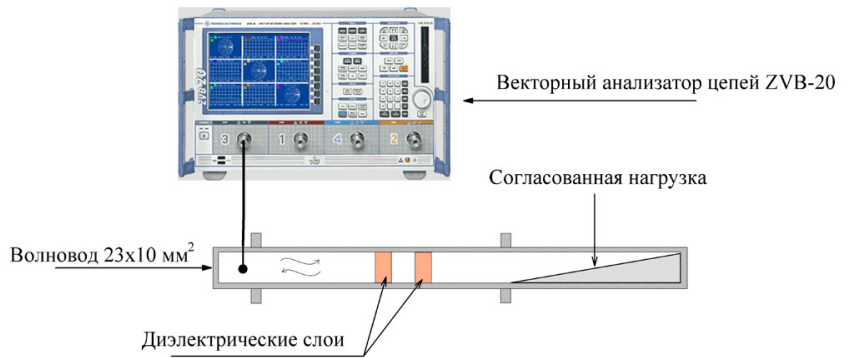

Рис. 18. Схема установки с многослойнылм фильтром. 
считать, что Алительность трапецеилального импульса $\tau$ много больше времени прохода волной уАвоенной толщины слоя. При этом в результате нестационарного отражения будет сформирован импульс, распространяющийся навстречу палающей волне. ЗаАаАим толщину полуволновых слоев равной $d=30$ мм, тогда толщина четвертьволнового слоя $d_{1}=21$ мм.

На рис. 19 представлен результат расчета поля $E_{\mathrm{r}}(t)$ отраженного импульса методом конечных разностей во временной области напряженности. Аля наглядности амплитуда отраженного сигнала увеличена в 20 раз.

ВиАно, что отраженный сигнац состоит из четырех коротких импульсов. Максимумы импульсов отраженного сигнала соответствуют моменту времени, когда огибающая падающего сигнала имеет максимум производной. Также виАно, что Ава центрацьных импульса имеют одинаковую фазу и находятся в противофазе с первым и последним импульсом.

При практической реализации многослойной структуры может возникнуть необходимость учета дополнительных физических явлений. Так, например, в условиях эксперимента в свободном пространстве может оказаться значительным явление Аифракции на краях пластинок и отклонение формы фронта палающей волны от плоской. Кроме того, появятся Аополнительные требования к точности позиционирования пластин и к их толщине. Не менее важным, как виАно из работы [42], является необходимость учета реальных потерь в слоях многослойной структуры.

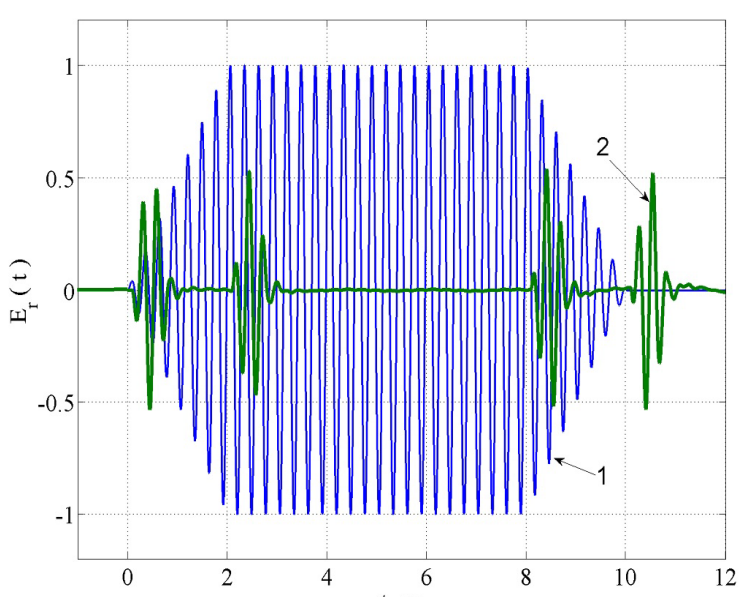

Рис. 19. Расчет поля $E_{r}(t)$ отранженного импульса, методом конечных разностей во временной области: 1 - падаюоий сигнал; 2 - отраженный сигнал.
Схема практической реализации рассмотренного фильтра сильно зависит от частотного Аиапазона, Аля которого он применяется. Так в оптическом диапазоне при синтезе многослойных фильтров используют подложку, на которую последовательно напыляют слои. В этом случае при синтезе фильтра необходимо учитывать не только потери в слоях структуры, но и Аисперсию материала, как слоев, так и подложки. В микроволновом Аиапазоне Алин волн подобного рода структуры могут быть реализованы в волноводе. В этом случае Аополнительно необходимо учитывать влияние Аисперсии волновода на коэффициент отражения. С Аругой стороны, решается проблема учета дифракции на краях пластинок и формы фронта падающей волны, так как пластинка полностью перекрывает сечение волновода.

В нашем случае изучалась модель волноводного фильтра, как наиболее удобная Аля экспериментального исследования. Рассмотрим Аанную модель подробнее и проведем ее численный анализ с учетом волноводной Аисперсии и потерь в слоях структуры.

Пусть слои, установлены в свободном прямоугольном волноводе, в котором возбуждена основная мода $H_{10}$. Будем считать, что слои изготовлены из диэлектрика с малыми потерями.

Тогда выражение Аля относительной Аиэлектрической проницаемости будет иметь виА $\varepsilon=\varepsilon^{\prime}-i \varepsilon^{\prime \prime}$ гле $\varepsilon^{\prime \prime}$ и $\varepsilon^{\prime}-$ мнимая и действительная части относительной Аиэлектрической проницаемости соответственно. Будем считать, что потери в слоях структуры малы $\varepsilon^{\prime \prime} / \varepsilon^{\prime}<1$.

В работе [42] было показано, что малые потери в образце не влияют на его оптическую толщину, в нашем случае - на резонансную частоту полуволнового слоя. Тогда дия расчета толщины слоев можно учитывать только Аисперсию волновода. В этом случае Аля расчета толщины слоев имеем:

$$
d=\operatorname{Re}(Z) \frac{c}{2 v},
$$

где $\operatorname{Re}(Z)$ - реальная часть импеданса слоя.

Анализ процесса нестационарного отражения требует перехода во временную область. Аیя этого воспользуемся обратным преобразованием Фурье. Как показало численное моделирование методом импедансных характеристик, наличие 
потерь в слоях структуры приводит к появцению отраженного сигнаца в области постоянной амплитуды падающего сигнала.

При измерении нестационарного отражения использовался полосовой фильтр, состоящий из Авух волновых пластинок из фоторопласта. Фторопласт имеет малые потери в микроволновом диапазоне частот [48, 49]. ПАастинки были установлены на расстоянии четверть Алины волны АруготАругапосерединепрямоугольноговолновода, чтобы максимально снизить влияние щелевых волн на измеряемый коэффициент отражения. Фильтр был настроен на частоту 8.4 ГГц и имел следующие геометрические размеры: толщина фторопластовых пластинок - 30.0 мм, толщина воздушного зазора межАу пластинками - 14.5 мм. Аиэлектрическая проницаемость фторопласта Аля Аанной частоты была предварительно измерена и составила $\varepsilon_{1}=2.05-0.015 i$.

В ходе эксперимента измерялся комплексный коэффициент отражения от структуры. А^я получения огибающей отраженного сигнаца использовалось обратное преобразование Фурье. На рис. 20 представлен результат теоретического моделирования и экспериментально измеренные огибающие импульса, отраженного от исследуемой структуры. Как видно, результаты теоретического расчета хорошо согласуются с экспериментальными Аанными. Экспериментальные результаты показали, что в процессе нестационарного отражения электромагнитного импульса от трехслойного фильтра с максимально плоской АЧХ формируются четыре коротких импульса. Положения импульсов совпадают с максимумами производной огибающей падающего сигнала.

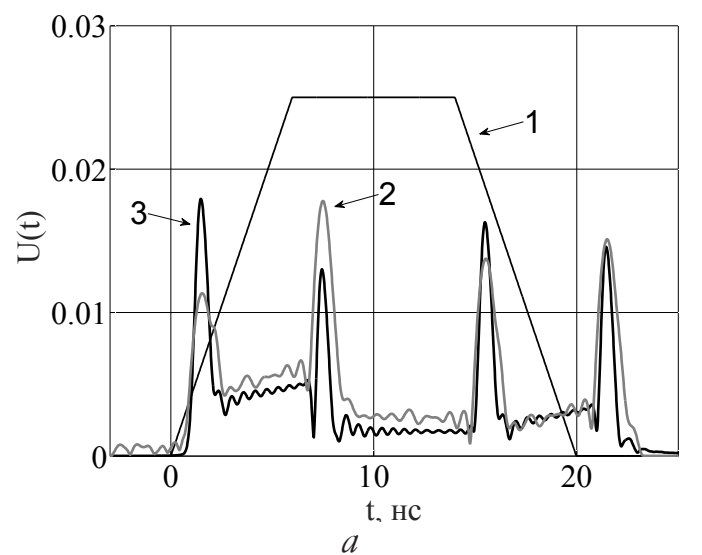

Сигнал, сформированный в процессе нестационарного отражения от рассмотренной структуры, принципиально отличается от сигнала, отраженного от однослойного фильтра.

Как и в случае полуволнового фильтра, потери в слоях структуры оказывают существенное вАияние на процесс нестационарного отражения. Также виАно, что существует момент времени, когАа амплитуда отраженного сигнала стремится к нуАю.

\section{5. ЗАКАЮЧЕНИЕ}

В настоящей работе преАставлен обзор основных результатов наших исследований последних мет явАения нестационарного отражения коротких и сверхкоротких (порядка 100 периодов колебаний поля) электромагнитных импульсов СВЧАиапазона от слоистых структур. Аанное явление особенно контрастно наблюдается в условиях сравнимости Алительности нестационарного переходного процесса интерференции волн в многослойной структуре с Алительностью падающего на нее импульса.

В ходе исследований была усовершенствована теория нестационарного отражения импульсных сигналов от многослойных интерференционных структур. Существующий теоретический аппарат Аополнен с учетом влияния на процесс нестационарного отражения потерь в слоях многослойной интерференционной структуры и сильной волноводной Аисперсии.

Разработаны экспериментальные методы изучения процесса нестационарного отражения сверхкоротких электромагнитных импульсов от многослойных интерференционных структур в СВЧ-Аиапазоне. Впервые получены результаты экспериментального наблюдения

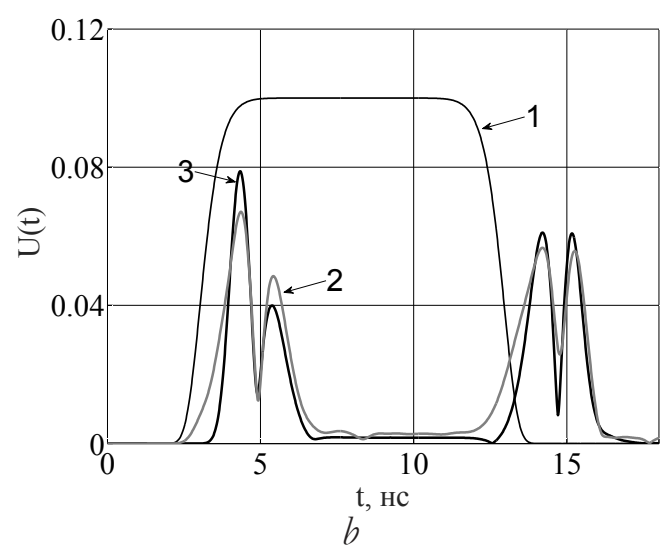

Рис. 20. Огибаючща отраженного сигнала для падатощего импульса с трапещеидальной огибаюощей (а) и с супергауссовой огибанощей (b) от трехслойного фильтра: 1 - огибатощая падаюощего сигнала; 2 - эксперимент; 3 - теория. 
яв $е$ ения

нестационарного

отражения

ампиитудно-модулированного

сигнала от

многослойной интерференционной структуры в СВЧ-диапазоне.

Было установ ено, что при отражении амплитудно-модулированного сигнала от полуво ннового слоя с потерями всегда существует момент времени, когда при ненулевой амплитуде падающего сигнала амплитуда отраженного сигнала стремится к нулю, а его фраза изменяется на $\pi$. При наличии малых потерь в слоях многослойной структуры амплитудный коэффициент отражения минейно зависит от величины потерь, в то время как формирование фазовой картины интерферирующих волн происходит в этом случае так же, как и в отсутствие потерь.

Решена задача согласования высокоотражающей нагрузки с волноводом за счет сильной волноводной Аисперсии. Показана

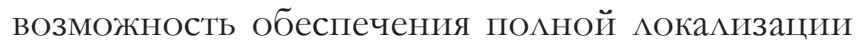
энергии падающей волны в нагрузке с практически Аюбым коэффициентом отражения с помощью согласующей структуры, состоящей всего из оАного слоя, толщина которого близка к четвертьво нновой.

Обнаружено наличие более сложного процесса нестационарного отражения в многослойных структурах неотражающего класса с максимально плоской амплитудночастотной характеристикой, по сравнению с многослойными структурами, имеющими Аругие функциональные зависимости амплитудночастотной характеристики.

Показано, что при малых потерях в слоях структуры с максимацьно плоской амплитудночастотной характеристикой огибающая отраженного сигнаца может быть приближенно описана $N$-ой производной от огибающей палающего сигнала.

\section{МИТЕРАТУРА}

1. Petrich JW, Fleming GR. Ultrafast processes in biology. Photochemistry and photobiology, 1984, 40(6):775-780.

2. Kling MF, Vrakkin MJ. Attosecond Electron Dynamics. Annual Review of Physical Chemistry, 2008, 59(1):463-492.
3. Rulliere C. Femtosecond Laser Pulses. New York, Springer, 2004, $218 \mathrm{p}$.

4. Szipocs R., et al. Chirped multilayer coatings for broadband dispersion control in femtosecond lasers. Photochemistry and photobiology, 1994, 19(3):201-203.

5. Kartner FX, Matuschek N, Schibli T, Keller U. Design and fabrication of double-chirped mirrors. Optics Letters, 1977, 22(11):831-833.

6. Matuschek N, Kartner FX, Keller U. Analytical design of double-chirped mirrors with customtailored dispersion characteristics. IEEE Journal of Quantum Electronics, 1999, 35(2):129-137.

7. Vernon SP, et. al. Chirped multilayer coatings for increased x-ray throughput. Optics Communications, 1993, 18:672-674.

8. Аадашадзе Н, Романов ОГ. Отражение оптических импульсов от многослойных Аиэлектрическихструктуримикрорезонаторов: численное решение уравнения Максвемла. Вестник БГУ, 2014,1(1):825-834.

9. Dennis WM, Liebig C. Simulation of High Intensity Ultrashort Pulse Interactions with Dielectric Filters. Proc. of SPIE, 2007:5989-23.

10. Liebig CM, Dennis WM. Simulation of interactions of high-intensity ultrashort pulses with dielectric filters. Optical Engineering, 2007, 46(2):023801.

11. Dunning Sarah. Optimizing Thin Film Filters for Ultrashort Pulse Shaping. Ph.D. thesis, The University of Georgia, 2003.

12. Michielssen E, Ranjithan S, Mittra R. Optimal multilayer filter design using real coded genetic algorithms. IEE Proceedings-J. Optoelectronics, 1992, 139(6):413-420.

13. Chen LR. Ultrashort optical pulse interaction with fibre gratings and device applications. Ph.D. thesis, University of Toronto, 1997.

14. Chen LR, Benjamin SD, et. al. Ultrashort pulse reflection from fiber gratings: a numerical investigation. Journal of Lightwave Technology, 1997, 15(8):1503-1512.

15. Быстров РП, Черепенин ВА. Теоретическое обоснование возможностей применения метода генерации мощных наносекундных импульсов электромагнитного излучения при создании радиолокационных систем электронной борьбы Аля поражения объектов. Журнал радиоэлектроники, 2010, 4. 
16. Schamiloglu E. High Power Microwave Sources and Technologies. New York, Wiley\&Sons, 2001.

17. Козарь АВ, Бобровников ЮА, Горохов ПН. Явление нестационарного отражения электромагнитных волн с изменяющейся амплитудой от слоистых структур. Известия РАН. Серия физическая, 2002, 12(1823):201-213.

18. Бобровников ЮА, Горохов ПН, Козарь АВ. Преобразование импульсов с помощью тонкослойных структур. Квантовая электроника, 2003, 53(11):1019.

19. Weiner MA. Ultrafast optical pulse shaping: A tutorial review. Optics Communications, 2011, 284:3669-3692.

20. Бушуев В.А. Временная компрессия импульсов рентгеновского мазера на свободных электронах в условиях брэгговской Аифракции. Радиоэлектроника. Наносистемы. Информачионнъе технологии (РЭНСИТ), 2014, 6(2):177-187.

21. Dunning FB. Atomic, Molecular, and Optical Physics: Electromagnetic Radiation. London, Academic Press, 1997, 406 p.

22. Бобровников ЮА, Козарь АВ, Горохов ПН. Нестационарное отражение электромагнитных импульсов от просветляющих тонкослойных структур. Трудыг VIII Всероссийской иколь-семинара "Волновыеляления в неоднородных средах", Москва, МГУ им. Аомоносова, 2002, 1(5):53-54.

23. Бобровников ЮА, Козарь АВ, Горохов ПН. Явление нестационарного отражения электромагнитных волн от просветляющих тонкослойных структур. Сб. докладов науиной конференчии "Домоносовские чтения". Секиия физики, подсекчия оптики и лазерной физики. Москва, МГУ им. Аомоносова, 2004, 1:31-33.

24. Козарь АВ. Интерференционные явления в слоистых структурах и их применение в задачах приема сигналов и диагностики неоднородных сред. Ph.D. thesis, Москва, МГУ им. МВ Аомоносова, 2004.

25. Борн М, Вольф Э. Основъ оптики, Москва, Наука, 1980.

26. Kozar AV. Spectral characteristics of thinlayer interference matching systems. Optics and Spectroscopy, 1988, 64(5):1130-1134.

27. Козарь АВ. Оптические и структурные свойства тонкослойных интерференционных согласователей. Оптика и спектроскопия, 1985, 59(5):1132-1136.

28. Ахманов СА, Выслоух ВА, Чиркин АС. Оптика фемтосекундных лазерных импульсов. Москва, Наука, 1988.

29. Виноградова МБ, Руденко ОВ, Сухоруков АП. Теория волн. Москва, Наука, 1990, 432 с.

30. Chipman RA. Transmission lines. New York, McGraw-Hill book company, 1968.

31. Peres PLD, de Souza CR, Bonatti IS. ABCD matrix: a unique tool for linear two-wire transmission line modelling. Intern. J. of Electrical Engineering Education, 2003, 40(3):220-229.

32. Матей $Г \Lambda$, Янг $\Lambda$, Ажонс ЕМТ. Фильтры СВЧ, согласуюшие уепи, уепи связи. Москва, Связь, 1971.

33. Yee K. Numerical solution of initial boundary value problems involving Maxwell's equations in isotropic media. Optical Engineering, 1966, 14(2):302-307.

34. Weiland T. A discretization method for the solution of Maxwell's equations for sixcomponent fields. Electronics and Communications AEU, 1977, 31(3):116-120.

35. Бреховских $\Lambda$ В. Волны в слоиствгх средах. Москва, Наука, 1973, 343 с.

36. Козарь АВ, Колесников ВС, Пирогов ЮА. О применении метода импедансных характеристик Аля анализа распространения волн в многослойных структурах с поглощением. Вестник Моск. ун-та, сер. Физика, астрономия, 1978, 19(2):76-83.

37. Tikhonravov AV, Trubetskov MK. Modern design tools and a new paradigm in optical coating design. Applied Optics, 2012, 51(30):7319-7332.

38. Вайнштейн $\Lambda$. Электромагнитные волны. Москва, Радио и связь, 1988.

39. Rohde and Schwarz. ZVT Vector Network Analyzers Operating Manual. Munich, Germany: Rohde\&Schwarz GmbH, KG, 2011.

40. Agilent Time Domain Analysis Using a Network Analyzer. Application Note 1287-12. Agilent Technologies, Inc, USA, 2007:1-48.

41. Айфичер Э, Ажервис Б. Цифровая обработка сигналов: практический подход. Москва, ИА "Вильямс", 2004, 992 с.

42. Козарь АВ, Трофимов АВ. Явление нестационарного отражения импульсных сигналов от слоистых структур с потерями. 
Вестник Моск. ун-та, сер. Физика, астрономия, 2013, 5:38-43.

43. Козарь АВ, Трофимов АВ, Потапов АA. Процесс нестационарного отражения коротких

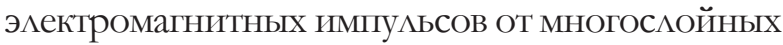
фильтров с максимально плоской амплитуАночастотной характеристикой. Журнал радиоэлектоники, 2016, 4:1-17.

44. Macleod HA. Thin-Film Optical Filters. London, Macmillan, 1986, 772 p.

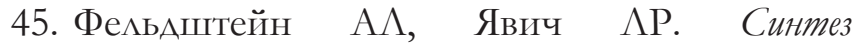
четырехполюсников и восьмиполюсников на СВЧ. Москва, Связь, 1971, 352 с.

46. Krepelka J. Maximally flat antireflection coatings. Jemná Mechanika A Optika, 1992, 37:53-56.

47. SchulzU, Schallenberg UB, Kaiser N. Symmetrical periods in antireflective coatings for plastic optics. Applied Optics, 2003, 42(7):1346-1351.
48. Кикоин ИК (реА.). Таблицьг физических величин. Справочник. Москва, Атомиздат, 1976, 1008 с.

49. Bur AJ. Dielectric properties of polymers at microwave frequencies: a review. Polymer, 1985, 26(7):963-977.

Трофимов Алексей Викторович к. Ф.-м.н.

МГУ им. М.В. Аомоносова, физический ф-т 1/2, Аенинские горы, Москва 119991, Россия av.trofimov@physics.msu.ru

Козарь Анатомий Викторович д.ф.-м.н., проф., действ. илен $\mathrm{PAEH}$ МГУ им. М.В. Аомоносова, физический ф-т 1/2, Менинские горы, Москва 119991, Россия avk@phys.msu.ru

\title{
NONSTATIONARY REFLECTION OF A SUPERSHORT ELECTROMAGNETIC PULSES FROM THE LAYERED STRUCTURES
}

\author{
Aleksey V. Trofimov, Anatoly V. Kozar' \\ Lomonosov Moscow State University, http://www.msu.ru \\ 1/2, Leninskie Gory, 119991 Moscow, Russian Federation \\ av.trofimov@physics.msu.ru,avk@phys.msu.ru
}

Abstract. Is carried out the theoretical and numerical study of non-stationary reflection of short and supershort electromagnetic pulses from a single-layer and multilayer interference structures, created test bench to measure of non-stationary reflection amplitude-modulated signal from the layered structure. It is shown that the envelope of the reflected signal substantially changes its appearance in the presence of even small losses in the non-reflection layers of the multilayer structure, the amplitude reflection coefficient depends linearly on the magnitude of the losses. At low loss in the layers of structure the envelope can be approximately described by the derivative of the $\mathrm{N}$-incident signal envelope. Obtained the exact and approximate formulas that allow to calculate the characteristics of the multilayer interference structure, highly reflective matching the load to the waveguide, the waveguide due to a strong dispersion. It is shown that in multilayer interference structures with strong waveguide dispersion there is a significant increase in the amplitude and duration of the pulses of non-stationary reflection.

Keywords: electromagnetic ultrashort pulses of microwave, layered structure with strong losses and waveguide dispersion, transient reflectivity, the envelope of the reflected signal, highly reflective and load matching structure, multilayer interference filters

UDC 544.77, 53.098 


\section{DIRAC MATERIAL GRAPHENE}

\section{Elena F. Sheka}

Russian Peoples' Friendship University of Russia, http://www.rudn.ru

117198 Moscow, Russin Federation

sheka@icp.ac.ru

Presented by Academician RANS S.P. Gubin

Abstract. The paper presents an overview on the spin-rooted properties of graphene, supported by numerous experimental and calculation evidence. Correlation of odd $p_{z}$ electrons of the honeycomb lattice meets a strict demand "different orbitals for different spins", which leads to spin polarization of electronic states, on the one hand, and generation of an impressive pool of local spins distributed over the lattice, on the other. These features characterize graphene as a peculiar semimetal with Dirac cone spectrum at particular points of the Brillouin zone. However, spin-orbit coupling (SOC), though small but available, supplemented by dynamic SOC caused by electron correlation, transforms graphene-semimetal into graphene-topological insulator (TI). The consequent topological non-triviality and local spins are proposed to discuss such peculiar properties of graphene as high temperature ferromagnetism and outstanding chemical behavior. The connection of these new findings with difficulties met at attempting to convert graphene-TI (usually taken as SM) into semiconductor one is discussed.

Keywords: graphene, Dirac fermions, quasi-relativistic description, hexagonal honeycomb structure, local spins, open-shell molecules, spin-orbital coupling, quantum spin Hall insulator, high temperature ferromagnetism, chemical activity

PACS: 51.05.ue

Bibliography - 79 references

Received 14.10.2016

RENSIT, 2016, 8(2):131-153

\section{CONTENTS}

1. INTRODUCTION (131)

2. Relativistic electrons of graphene (132)

3. Characteristics of THE Dirac CONE SPECTRA (133)

4. Dirac Fermions AND topological nONTRIVIALITY OF GRPHENE (135)

5. Molecular essence AND topological CHARACTER OF GRAPHENE MAGNETISM (136) 5.1. General Features of Experimental Observations (136)

5.2. Magnetic Behavior of Graphene Molecules (137)

5.3. High-Temperature Ferromagnetic Topological Insulating Phase of Graphene (139)

6. LOCAL SPINS IN GRAPHENE MOLECULE LANDSCAPE (142)

7. INTRODUCTION TO GRAPHENE COMPUTATIONAL SPIN CHEMISTRY (145)

8. Comments ON CONVERTING GRAPHENE FROM SEMIMETAL TO SEMICONDICTOR (146)
9. Conclusion (149)

References (150)

\section{INTRODUCTION}

The current paper concerns three main issues underlaying spin features of graphene: (1) a significant correlation of the $p_{z}$ odd electrons, exhibited in terms of spin peculiarities of the unrestricted Hartree-Fock (UHF) solutions, (2) disputable spin-orbital coupling (SOC) and (3) the crucial role of the $C=C$ bond length distribution over the body in exhibiting the spin-based features. Despite numerous and comprehensive studies of graphene performed during the last decade [1], the spin-rooted peculiarities, involved in the graphene physics and chemistry, still remain outside the mainstream. However, graphene is doubtlessly of a spin nature and the main goal of the paper is to clarify how deeply electronic states of graphene molecules and solids are spin-burdened. 


\section{RELATIVISTIC ELECTRONS OF GRAPHENE}

Implementing Löwdin's statement "different orbitals for different spins" [2], nonrelativistic correlation effects in electronic properties are well pronounced and form the ground for peculiarities of chemical $[3,4]$, magnetic [5], and mechano-chemical [6] behavior of graphene. In contrast, the relativistic SOC contribution related to graphene bodies consisting of light elements is expectedly small (see [7] and references therein). Despite this, the quasi-relativity theory has accompanied graphene crystal from the first consideration of its electronic structure $[8,9]$. The primitive cell of graphene is simple and contains two atoms. However, these cells are additionally hexagonally configured to fit the honeycomb lattice, on the one hand, and to provide the hexagonal and flat first Brillouin zone (BZ), on the other. The BZ contains two nonequivalent sets of three vertices $K$ and $K^{\prime}$ each while $\Gamma$ point is located at the hexagon centre. In the tightbinding approach it is typical to separate the Hamiltonian for the $\pi\left(\operatorname{odd} p_{z}\right)$ electrons from that for the $\sigma$ electrons, which is strictly valid only for a flat graphene sheet. Thus obtained [10], the total band structure of graphene crystal is of particular image, typical view

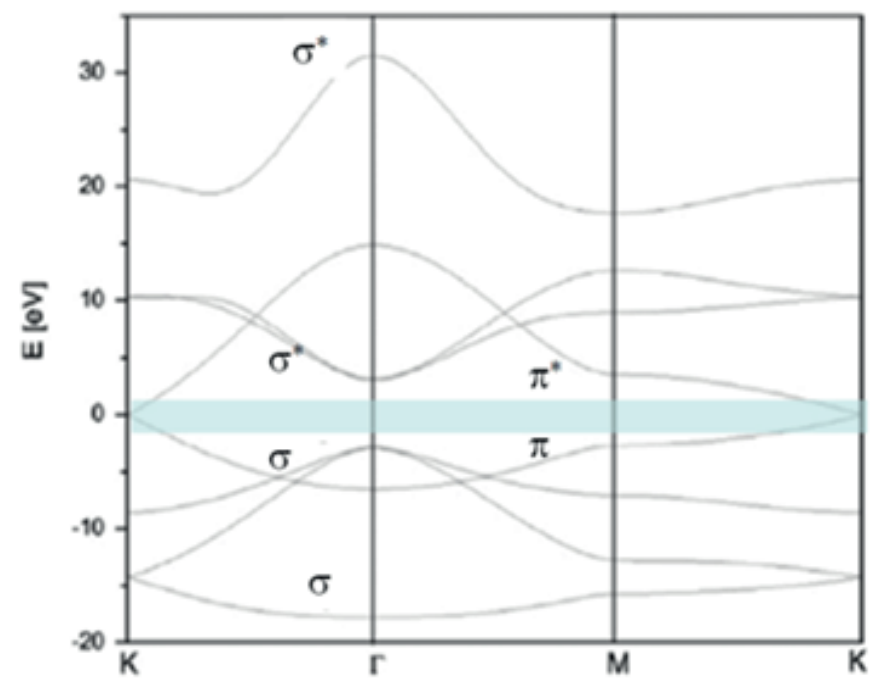

Fig. 1. (a) Widely presented view on the band structure of graphene. Fermi level is settled at zero. The bands below (above) the Fermi level

of which is presented in Figure $1 a$. Since referring relativistic analogy concerns $\pi$ bands, it is conventional to just consider the latter. The relevant low-energy quasiparticle states at the Fermi level, marked by a tinny band in the figure, form six pairs of touching cones with the tips at $K\left(K^{\prime}\right)$, two pairs of which are shown in Fig. 1b. The total lowenergy electronic spectrum of the graphene six pairs is described [11] as

$$
\begin{aligned}
& E_{1}\left(k_{0}+\kappa\right)=E^{0}-\left(\frac{\hbar p_{0}}{m}\right) \kappa, \\
& E_{2}\left(k_{0}+\kappa\right)=E^{0}+\left(\frac{\hbar p_{0}}{m}\right) \kappa .
\end{aligned}
$$

Here $E^{0}$ and $k_{0}$ are the Fermi energy and quasiparticle momentum at points $K\left(K^{\prime}\right)$ while the $E_{1}$ and $E_{2}$ spectra are related to the conducting and valence bands, respectively. A detailed description of parameter $\hbar p_{0} / m$ is given in Ref. [11]. Equations (1) are well similar to those related to Dirac's massless fermions due to which the low-energy quasiparticles in the vicinity of $K\left(K^{\prime}\right)$ points (Dirac points later) can formally be described by the Dirac-like Hamiltonian

$$
\widehat{H}=\hbar v_{F}\left(\begin{array}{ll}
0 & k_{x}-i k_{y} \\
k_{x}+i k_{y} & 0
\end{array}\right)=\hbar v_{F} \boldsymbol{\sigma} \cdot \boldsymbol{k}
$$
are related to the valence (conductive) zones. (b) Two pairs of valence/ conductive Dirac cones at K and $K$ ' points at the Fermi level. 
where $\mathbf{k}$ is the quasiparticle momentum, $\boldsymbol{\sigma}$ is the $2 D$ Pauli matrix for pseudospins and the $k$-independent velocity $\mathrm{v}_{\mathrm{F}}$ plays the role of the speed of light. The equation is a direct consequence of graphene's crystal symmetry that involves its honeycomb hexagonal lattice $[9,11]$. Owing to this specific electron band structure, graphene was attributed to a Dirac material and until now graphene has been considered as a 'solid-state toy' for relativistic quantum mechanics [12-14]. Since the graphene massless Dirac fermions move with the Fermi velocity $\mathrm{v}_{\mathrm{F}} \sim 10^{6} \mathrm{~ms}^{-1}$, it is possible to mimic and observe quantum relativistic phenomena, even those unobservable in high energy physics, on table-top experiments at much lower energies due to the small value of the $\mathrm{v}_{\mathrm{F}} / c$ ratio. Thus, a quite satisfactory consistency between theoretical predictions and experimental observations has even allowed one to speak about the observation of Dirac fermions in graphene. Taking them as physical reality, one has suggested a specific engineering of different Dirac fermions by modulating their Fermi velocity when attaching graphene to different substrates [15]. As seen in Figure 2, an impressive change of $\mathrm{v}_{\mathrm{F}}$ from $1.15 \cdot 10^{6} \mathrm{~ms}^{-1}$ to $2.46 \cdot 10^{6} \mathrm{~ms}^{-1}$ is observed when substituting the $\mathrm{SiC}(000 \overline{1})$ substrate by quartz.

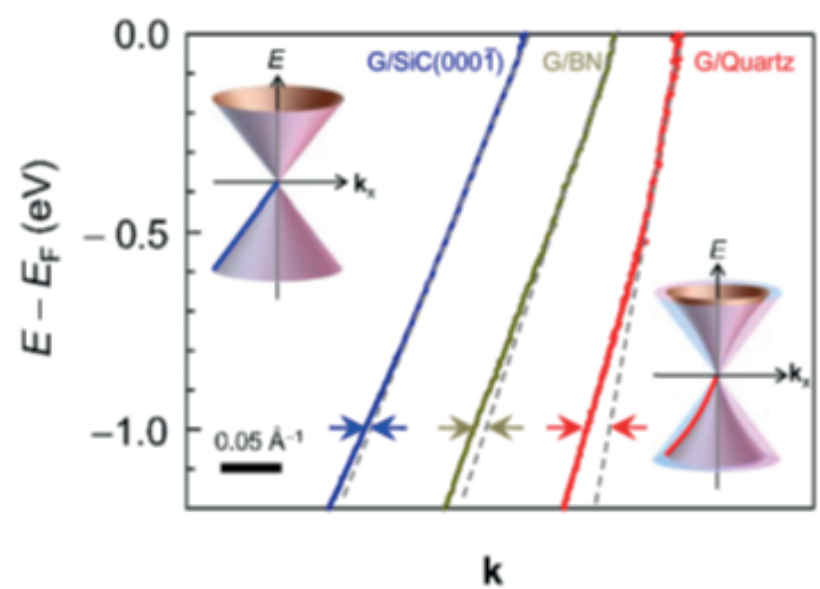

Fig. 2. Experimental $E_{2}\left(k_{0}+\kappa\right)$ dispersions for graphene on $\operatorname{SiC}(000 \overline{1}), B N$, and quart: Insets exbibit changing in the graphene Dirac cones when going from weak (left) to strong (right) interaction with substrate [15].

\section{CHARACTERISTICS OF THE DIRAC CONE SPECTRA}

Dirac cones are a specific crystal symmetry effect, that suits any flat (even quasiflat) hexagonal arrangement of atoms similar to the honeycomb lattice that supply hexagonal BZ. Actually, the Dirac-fermion-like behavior of electronic states was observed for monolayers of silicon atoms on a $\mathrm{Ag}(111)$ surface voluntarily attributed to 'silicene' species [16] (see detailed discussion of the reality and virtuality of silicene in Ref. [17]). Similar behavior was predicted for higher tetrels of group 14 elements - germanene and stanene [18]. Particular attention should be given to a new class of artificial 'molecular graphenes' that mimic a honeycomb lattice structure. One of such 'molecule' was synthesized using individually placed carbon monoxide molecules on a $\mathrm{Cu}(111)$ surface [19]. A completed 'flake' of the molecular graphene is shown in topographic form in Figure 3a, demonstrating a perfect internal honeycomb lattice and discernible edge effects at the termination boundaries. In spite of the finite size of the structure obtained, due to which it should be attributed rather to 'molecular graphene' than to 'graphene crystal', as seen in Fig. 3b, two energy cones are characteristic for the energy band structure near the Fermi level. Estimations showed that the crystal-like behavior is well conserved when the molecule size is of $20 \mathrm{~nm}$ or more.

The other quite peculiar ability to create artificial graphene-like structure utilizes an optical honeycomb lattice to trap ultracold potassium atoms [20]. A Dirac-cone-like band structure is reproduced in this system as well. This optical method of creating the honeycomb lattice suggests a large possibility to investigate factors influencing the Dirac cones structure. Thus, by tuning the anisotropy of the lattice, the locations of the Dirac points may be shifted. When the anisotropy reaches a certain limit, the Dirac points merge and annihilate, while the evidence supporting the existence of a theoretically predicted topological phase 

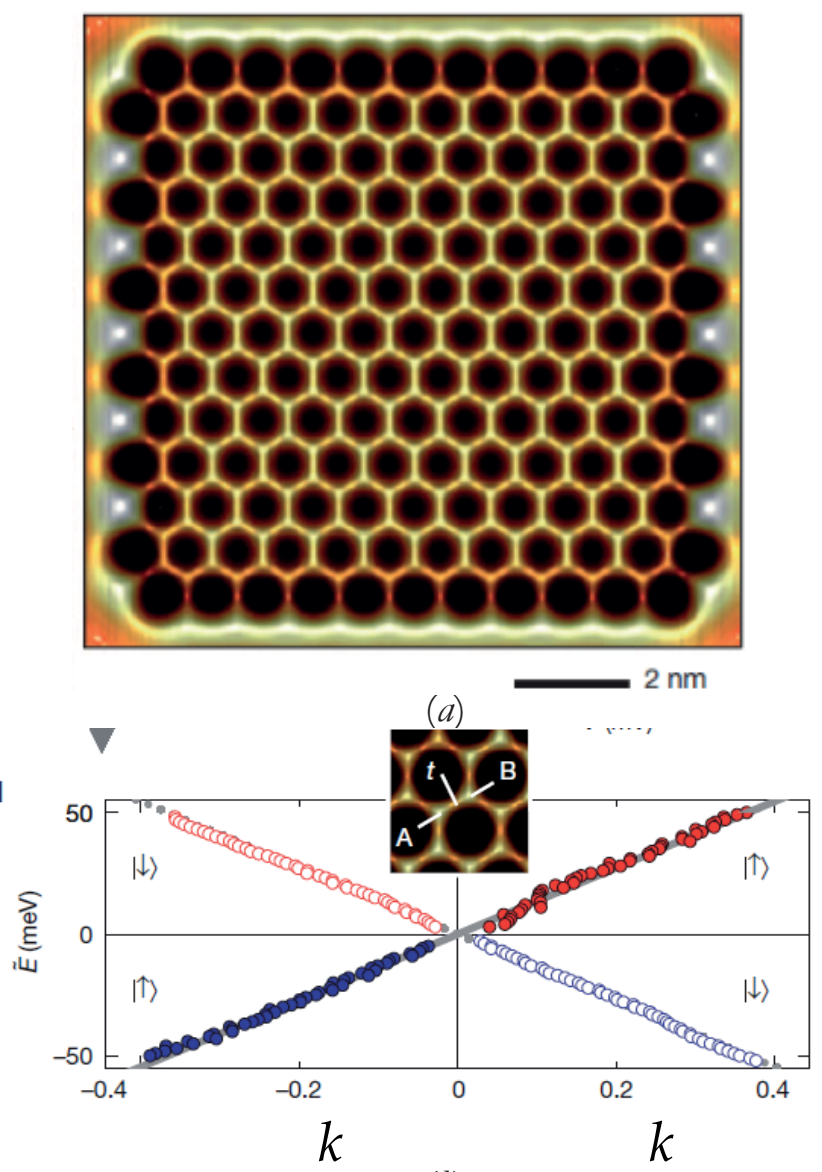

(b)

Fig. 3. (a) Constant current topograph of molecular graphenelike lattice composed of 1549 CO molecules (lattice constant, $d=8.8$ A). (b) Linearly dispersing quasi-particles revealed by the conductance spectra, plotted individually for sublattice $A$ (filled circles: psendospin $s_{2}=+1 / 2$ ) and sublattice $B$ (open circles: pseudospin $\left.s_{z}=-1 / 2\right)$, measured at locations $t$ illustrated in the inset. Adapted from Ref. [19].

transition was observed.

A number of theoretical suggestions on the Dirac-graphene-like structure is quite impressive. They cover virtual silicene, germanene, stannene (see review [21] and references therein), hydrogenated borophene [22] and arsenene [23]. All the Dirac species are described by hexagon packing of two-atom primitivecells. However, 'the primitive cell' may be considerably complicated as it takes place in the case of $s$-triazines with primitive cells composed of either $\mathrm{C}_{6} \mathrm{~N}_{6}$ or $\mathrm{C}_{12} \mathrm{~N}_{6}$, and $\mathrm{C}_{24} \mathrm{~N}_{6} \mathrm{H}_{12}$ molecular compositions [24], graphitic carbon nitride (GCN) with $\mathrm{C}_{14} \mathrm{~N}_{10}$ as a primitive cell [25], beautiful hexagon patterned lace of $\mathrm{NiC}_{8} \mathrm{~S}_{2} \mathrm{H}_{4}$ molecules [26], the $\mathrm{FeB}_{2}$ monolayer with graphene-like boron sheet [27], an impressive number of MXenes [28] (a new class of inorganic 2D compounds [29]), just appeared new compounds InSe [30] and so forth. The conservation of the hexagon packing of primitive cells mentioned above protects the presence of Dirac cones in the electronic spectra of all the species.

Virtually all the Dirac spectra discussed above were calculated not paying attention to if the studied system is open- or closed-shell one and exploiting closed-shell formalism. Only two calculations related to $\mathrm{GCN} \mathrm{C} \mathrm{C}_{14} \mathrm{~N}_{10}$ [25] and metal-organic framework with primitive cell $\mathrm{Ni}_{2} \mathrm{C}_{24} \mathrm{~S}_{6} \mathrm{H}_{12}[26]$ were obtained takinginto account that electrons with $\alpha$ and $\beta$ spins are correlated and separated in space. The open-shell approach immediately revealed the spin-polarization of the electronic spectra just doubling the band number and combining them in $\alpha$ and $\beta$ sets. Figure $4 a$ presents the spin-polarized band structure of GCN while Fig. 4b is related to metal-organic framework. The configurations of the relevant primitive cells are shown under the spectra. Both primitive cells contain an even number of valence electrons, $N^{\alpha}=N^{\beta}$ so that in neither case
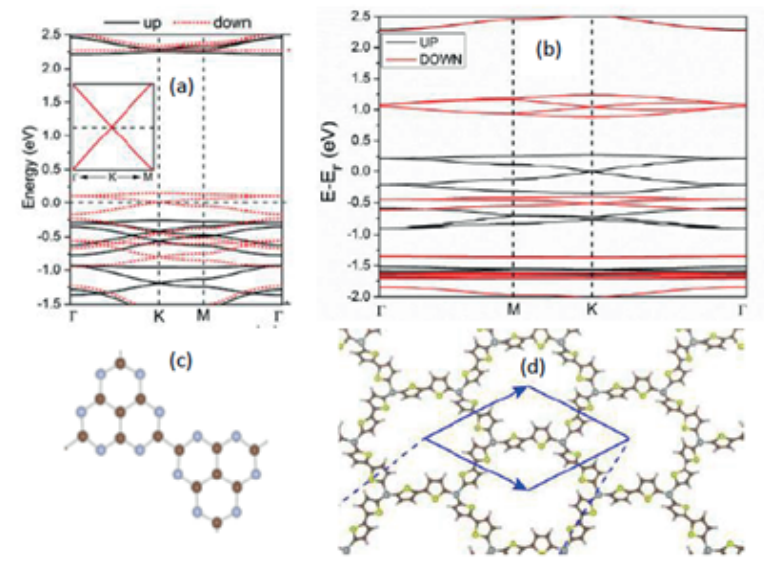

(e)

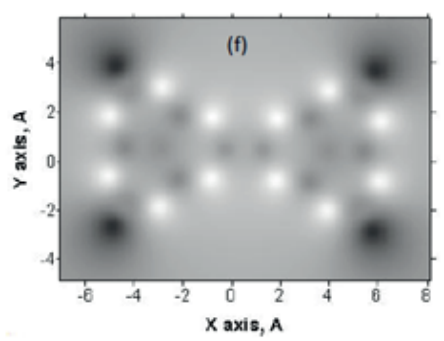

Fig. 4. Spin-polarized band structure and primitive cell of GCN $\mathrm{C}_{14} \mathrm{~N}_{10}(\mathrm{a})$ and (c) and $\mathrm{Ni}_{2} \mathrm{C}_{24} \mathrm{~S}_{6} \mathrm{H}_{12}($ b) and (d). Adapted from Refs. [25] and [26], respectively. Equilibrium structure (e) and the ACS $N_{D A}$ image map of local spin distribution (f) of the $\mathrm{C}_{14} \mathrm{~N}_{10} \mathrm{H}_{4}$ molecule; UHF AM1 calculations. 
are there unpairing free spins, since the total spin density is zero. In the case of GCN, the authors [25] explain the observed spin polarization from a chemical bonding analysis and attribute it to reducing the anti-bonding characteristics and density of states at Fermi level.

However, it is quite reasonable to suggest an alternative explanation and connect the obtained spin polarization caused by $p_{z}$ electron correlation with the open-shell character of the electronic system of both cells [7]. In fact, as shown in Fig. 4e, in view of the UHF formalism the molecule $\mathrm{C}_{14} \mathrm{~N}_{10} \mathrm{H}_{4}$, that perfectly mimics the GCN primitive cell, is open-shell one with the total number of effectively unpaired electrons $N_{D}$ $=5.34 \mathrm{e}$ that are distributed as 'local spins' over nitrogen and carbon atoms with an average $N_{D A}$ fractions of $0.285 \pm 0.001 \mathrm{e}$ and $0.145 \pm 0.003 \mathrm{e}$, respectively (see Fig. 4f). Therefore, the band spin polarization becomes the manifestation of the electron correlation in $2 D$ open-shell solids. As seen in Fig. 4, the spin polarization is well pronounced through over both BZs while at $K$ points the Dirac spectra still remain gapless. Apparently, the feature is still caused by the hexagon packing of the molecules. Opening the gap at Dirac points needs the participation of SOC that has been so far ignored.

The disclosed connection between the openshell character of the electronic system and spin polarization of the electronic band spectra brings us back to graphene. First, the character peculiarity was mentioned with relation to graphene magnetism and was illustrated by a convincing spin density map related to the rectangle graphene molecule $(5,5) \mathrm{NGr}$ with five benzenoid units along the armchair and zigzag edges, respectively [5]. Second, it concerned the dispersion of the $C=C$ bond length related to the body [31]. Now there is the third time when we have to realize the inevitability of spin polarization of the graphene electronic band structure. While the relevant results concerning the band structure of graphene are still in future, Figure 5 presents the energy splitting related

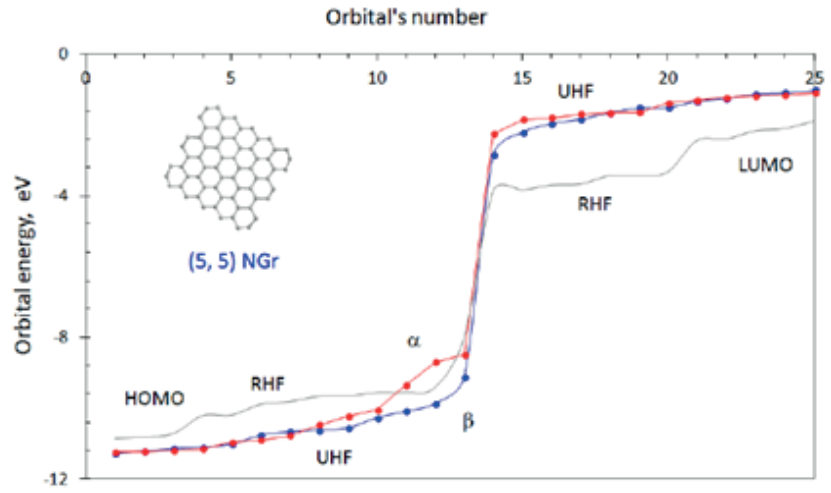

Fig. 5. Energies of 25 spinorbital in the vicinity of HOMOLUMO gap of $(5,5) \mathrm{NGr}$ molecule with bare edges; UHF AM1 calculations.

to a selected number of spinorbitals of the (5, 5) NGr molecule. A comparison of RHF and UHF results allows exhibiting correlation effects related to the studied open-shell molecule. The degeneracy of the RHF solution is caused by both high spatial $\left(D_{2 \mathrm{~h}}\right)$ and spin symmetry of the molecule. As seen in the figure, when going from RHF to UHF formalism the UHF orbitals become clearly split into two families related to $\alpha$ and $\beta$ spins. The splitting value is different for different orbitals ranging from $0.02 \mathrm{eV}$ to $1.12 \mathrm{eV}$. The orbitals splitting exhibits breaking spin symmetry that causes a remarkable distinguishing of orbitals related to different spins.

\section{DIRAC FERMIONS AND TOPOLOGICAL NON-TRIVIALITY OF GRAPHENE}

As shown above, spin polarization does not affect the cones touching in the Dirac spectrum shown in Fig. 1 (see insert in Fig.4a) that may be violated by SOC only. At the same time, the intrinsic SOC of graphene is quite negligible due to which the gap emergence in its Dirac spectrum should be hardly expected. However, the electron correlation, which is significant, generates a dynamical SOC (see Ref. [32] and references therein) due to which it might be possible to expect some relativistic features, observable at even negligible intrinsic SOC but at a significant electron correlation. The first potential effect concerns the splitting of the Dirac spectrum. To examine if the splitting 
can be observed for graphene experimentally, the team of Novoselov and Geim performed a particular investigation of how close one can approach the Dirac point [33]. It was shown that the approach value $\delta E$ depends on quality and homogeneity of samples, on the resolution of experimental equipment, on temperature, and so forth. The best value $\delta E$ related to free standing sample constitutes $\sim 1 \mathrm{meV}$ at $4 \mathrm{~K}$, thus establishing that there is no bandgap in graphene larger than $0.5 \mathrm{meV}$ and that a combined SOC effect is less this value. Nevertheless, the finding does not disprove the existence of SOC as such, which may be important in the case of other effects, more sensitive to weak SOC. One of such potential effects concerns the topological non-triviality of graphene.

Actually, electron correlation and SOC are crucial characteristics of the topological non-triviality of $2 \mathrm{D}$ bodies. This question has been clear since the very time of the Dirac topological insulator (TI) discovery [34]. In the case of graphene, negligible SOC and complete ignorance of electron correlation, caused by calculations performed in the restricted formalism, were major obstacles to a serious discussion of this issue. However, the topological non-triviality covers a large spectrum of different topological states and phases involving both ideal Dirac TIs (or quantum spin Hall insulators - QSHI) and other topological issues such as correlated topological band insulators, interactiondriven phase transitions, topological Mott insulators and fractional topological states [32] interrelation between which is determined by that one between SOC and correlation effects. Figure 6 presents a phase diagram of topological states characteristic for $2 D$ graphene-like honeycomb lattice (known as Kane-Mele model [9]) in relative coordinates of correlation energy $(U)$ and SOC $\left(\lambda_{\text {SO }}\right)$, which correspond to the Hubbard model. As seen in the figure, in the limit case $\lambda_{\text {SO }}=0$, the relevant $2 D$ structures should be attributed to either semimetal (SM) or quantum spin liquid (QSL) and antiferromagnetic Mott insulator (AFMI) with Heisenberg order ( $x y z$ ), depending on the correlation energy. The SOC increasing transforms SM solid and QSL into QSHI at a rather large scale of the correlation energy variation. When the value achieves the critical one shown by the straight line, the QSHI transforms into AFMI with easy plane order $(x y)$. In the limit case $U=0$, the solid should behave as QSHI at all $\lambda_{\text {SO }}$.

Concerning graphene, recent estimation of $U / t=1.6$ [35] allows placing graphene far below the border with the QSL and AFM phases and attributing it to the SM phase if $\lambda_{\text {so }}=0$. However, the doubtless presence of the correlation of graphene $p_{\mathrm{z}}$ electrons causes unavoidable breaking of Kramers pairs of spinors [36], which violates the time-reversal
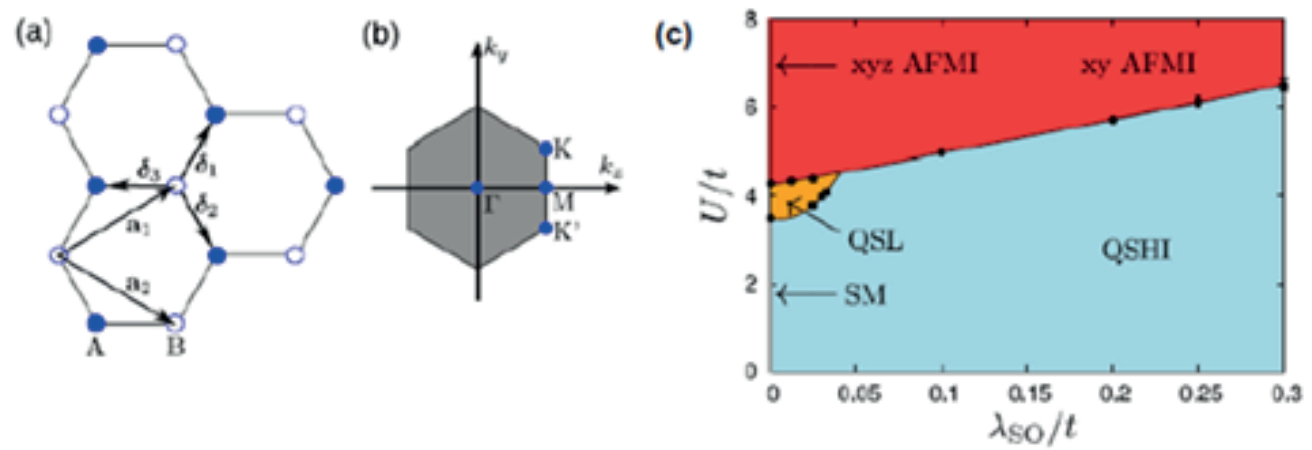

Fig. 6. (a) Kane-Mele model of the honeycomb lattice consisted of two sublattices $A, B$. (b) The hexagonal first Brillouin zone contains two nonequivalent Dirac points $K$ and $K^{\prime}$. (c) Phase diagram of the half-filled Kane-Mele-Hubbard model from quantum Monte Carlo simulations. Adapted from Ref. [32]. 
symmetry, on the one hand, and stimulates the origin of dynamic SOC, on the other [32]. The findings shift graphene along the $\lambda_{\mathrm{SO}} / t$ axis in the depth of the QSHI phase thus providing a vivid topological non-triviality of graphene that might be revealed by not only the SOCstimulated energy gap splitting. One of such topological effects has a direct bearing to peculiarities of graphene magnetism.

\section{MOLECULAR ESSENCE AND TOPOLOGICAL CHARACTER OF GRAPHENE MAGNETISM}

\subsection{General Features of Experimental Observations}

Repeatedly controlled extended graphene sheets are diamagnetic and magnetic response from large samples was empirically obtained only after either, say, heavy irradiation by proton beams or chemical modification (hydrogenation, oxidation and so forth) of graphite and/or graphene (see [37] and references therein). Thorough analysis, performed in each case, allowed excluding the impure origin of these features and attributing them to graphite/graphene itself, albeit induced by either micro- and/or nano-structuring of the samples or by defects of different topology created in due course of chemical modification (see some example [38-41]). It is important to mention that practically in all the cases a ferromagnetic response at room temperature was observed for graphene species with zero total spin density.

Another scenario concerns magnetic graphene of a paramagnetic behavior [40-42] recorded after either fluorination or bombarding graphene laminates consisting of $10-50 \mathrm{~nm}$ sheets by protons. The treatment provided the rupture of double $C=C$ bonds inducing 'spinhalf paramagnetism' in graphene. In both cases, the magnetization is weak and is characterized by one spin per approximately 1.000 carbon atoms. The ratio indicates that, in fact, the aftertreatment magnetic crystal structure differs from the pristine crystal structure and the difference concerns the unit cell that becomes $\sim 33 / 2$ times larger than the previous one. Besides, the unit cell contains one additional spin thus lifting the spin multiplicity to doublet. Therefore, introduced adatoms and point defects cause a magnetic nanostructuring of the pristine crystal but with non zero spin density.

A doubtless confirmation that the nanostructuring of graphene sheets plays a large role in magnetization was obtained in the course of specifically configured experiments $[43,44]$. Both cases concern meshed graphene or graphene in pores that were formed by either fully hydrogenated (oxidized) graphene discs in the first case or $\mathrm{MgO}$ nanoparticles in the second. A view on the sample and obtained results related to the first case can be obtained by looking at Figure 7. A large graphene sheet is put on porous alumina template (see Fig. 7a). The sample was subjected to either hydrogenation or oxidation through alumina pores thus leaving the graphene webs between the pores untouched. The web width $\mathrm{W}$ in a set of alumina templates differed by 10 to $50 \mathrm{~nm}$. The ferromagnetic response of the webs at room temperature is presented in Figs. $7 \mathrm{~b}$

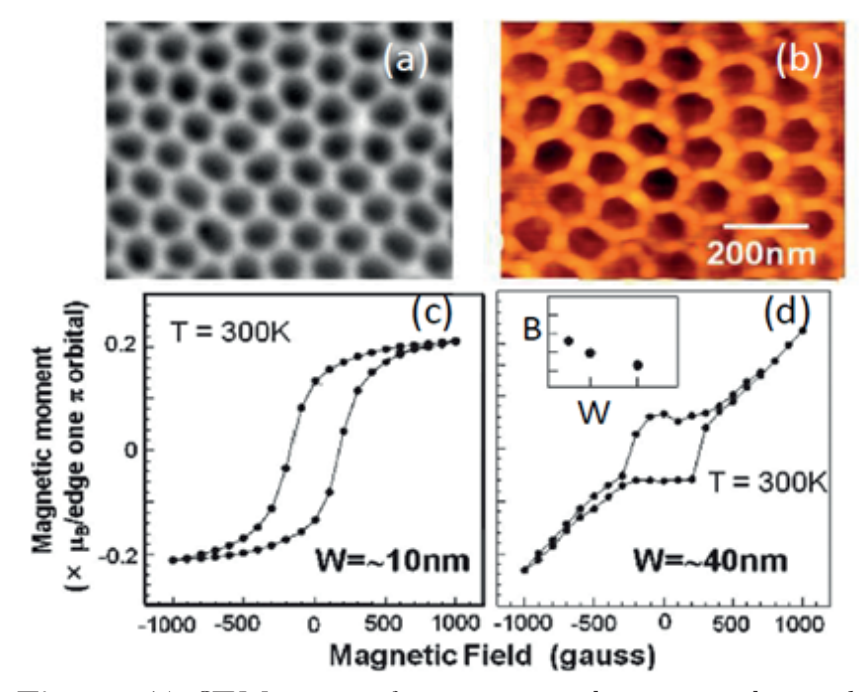

Fig. 7. (a) SEM image of nanoporous alumina template with mean pore diameter $\sim 80 \mathrm{~nm}$ and mean interpore spacing $W \sim 20$ nm. (b) AFM image of graphene nanopore array formed by using (a) as an etching mask for the sample one-side hydrogenation. (c) and (d) Magnetization of monolayer graphene nanopore arrays at $W \sim 10 \mathrm{~nm}$ and $40 \mathrm{~nm}$. Inset presents the dependence of the residual magnetization of graphene webs on their width W. Adapted from Ref. [43]. 
and $7 \mathrm{c}$ at different web widths and the inset in Fig. 7c reveals the width dependence more clearly. In the second case, chemically modified dark disks in Fig. 7a were substituted with $\mathrm{MgO}$ nanoparticles, a set of which was covered by CVD grown graphene tissue [44]. The web width between the particles constituted $\sim 10 \mathrm{~nm}$. The magnetic response from the sample is similar to that presented in Fig. $7 \mathrm{~b}$ while the signal from much larger pieces $\sim 100 \mathrm{~nm}$ of technical graphene (reduced graphene oxide) was a few times less.

Therefore, nanosize occurrence and sizedependence, on the one hand, and hightemperature ferromagnetic character, on the other, are two peculiar features of zero-spindensity graphene magnetism. Evidently, the former concerns the magnetization magnitude and is associated with the molecular essence of graphene while the latter is relevant to the magnetism grounds and applies to its physics thus revealing the molecular-crystalline dualism of graphene once more.

\subsection{Magnetic Behavior of Graphene Molecules}

Zero-spin-density graphene implies the absence of free spins, since graphene belongs to a species for which $N^{\alpha}=N^{\beta}$. Usually such magnetic species were attributed to 'singlet magnets' (in terms of closed-shell approximation) and their magnetization was associated with the effect of the second order of perturbation theory (PT) implying the mixture of the ground singlet state with higher laying states of higher spin multiplicity. If the mixture is caused by the application of magnetic field, the effect is known as van Fleck magnetization [45]. However, graphene is an open-shell species due to which its singlet ground state has already been spin mixed due to odd $p_{z}$ electron correlation. Since the spin contamination is the PT second order effect as well [7], there is no need to apply to the van Fleck effect to explain this magnetism. The magnetization ability of graphene has been already ensured by its electronic system.
The observation of the PT second order contributions strongly depends on the energy denominator among other factors. For covalent species, triplet states are the main contributors due to which the energy denominator is $2|J|$, where $J$ is the exchange integral that determines the energetic dependence of pure spin states in terms of the Heisenberg Hamiltonian $\mathrm{H}_{\mathrm{ex}}=J S(S+1)$. The integral is usually referred to as the magnetic coupling constant [46]. A correct computation of the constant is quite complicated. Thankfully, about four decades ago Noodelman suggested a simple expression for the value determination for open-shell molecules in the framework of the broken spin symmetry approximation [46]

$$
J=\frac{E^{U}(0)-E^{U}\left(S_{\max }\right)}{S_{\max }^{2}} .
$$

Here, $E^{\mathrm{U}}(0)$ and $E^{\mathrm{U}}\left(S_{\max }\right)$ are energies of the UHF singlet and the highest-spin-multiplicity states, the latter corresponding to the $S_{\max }$-purespin state. Thus obtained value is widely used and attributing it to molecular magnetism showed [48] that the measurable magnetization response can be fixed if $|J| \leq\left|J_{\text {crit }}\right|$ where empirically estimated $J_{\text {crit }}$ is of $10^{-2}-10^{-3} \mathrm{kcal} / \mathrm{mol}$. Based on the molecular essence of graphene magnetism, let us look which $J$ values can be expected for graphene molecules.

Table 1 lists sets of three criterial quantities: $\Delta E^{\mathrm{RU}}, \Delta\langle S\rangle^{2}$ and $N_{D}$, which characterize any open-shell molecule [4]. The data were evaluated for a number of graphene

Table 1 Identifying parameters of the odd electron correlation in rectangulsr nanographenes

\begin{tabular}{|c|c|c|c|c|c|c|c|}
\hline $\begin{array}{c}\left(\mathrm{n}_{\mathrm{a}}, \mathrm{n}_{\mathrm{z}}\right) \\
\mathrm{NGrs}\end{array}$ & $\begin{array}{c}\text { Odd } \\
\text { electrons } \\
\mathrm{N}_{\text {odd }}\end{array}$ & $\begin{array}{c}\Delta \mathrm{E}^{\mathrm{RU} 1} \\
\mathrm{kcal} / \mathrm{mol}\end{array}$ & $\delta \mathrm{E}^{\mathrm{RU},}, \%^{2}$ & $\mathrm{~N}_{\mathrm{D}}, \mathrm{e}^{-}$ & $\delta \mathrm{N}_{\mathrm{D}}, \%^{2}$ & $\Delta \hat{S}_{U}^{2}$ & $\begin{array}{c}\mathrm{J} \\
\mathrm{kcal} / \mathrm{mol}\end{array}$ \\
\hline$(5,5)$ & 88 & 307 & 17 & 31 & 35 & 15.5 & -1.429 \\
\hline$(7,7)$ & 150 & 376 & 15 & 52.6 & 35 & 26.3 & -0.888 \\
\hline$(9,9)$ & 228 & 641 & 19 & 76.2 & 35 & 38.1 & -0.600 \\
\hline$(11,10)$ & 296 & 760 & 19 & 94.5 & 32 & 47.24 & -0.483 \\
\hline$(11,12)$ & 346 & 901 & 20 & 107.4 & 31 & 53.7 & -0.406 \\
\hline$(15,12)$ & 456 & 1038 & 19 & 139 & 31 & 69.5 & -0.324 \\
\hline
\end{tabular}

1AM1 version og UHF codes of CLUSTER-Z1 [49]. Presented energy values are rounded off to an integer.

${ }^{2}$ The percentage values are related to $\delta E^{R U}=\Delta E^{R U} / E^{R}(0)$ and $\delta N_{D}=N_{D} / N_{\text {odd }}$, respectively. 
molecules presented by rectangular $\left(n_{a}, n_{a}\right)$ fragments ( $n_{a}$ and $n_{z}$ count the benzenoid units along armchair and zigzag edges of the fragment, respectively). Consequently, the table as a whole presents the size dependence of the UHF peculiarities of the open-shell graphene molecules. As seen in the table, the parameters are certainly not zero, obviously greatly depending on the fragment size while their relative values are practically non sizedependent. Attention should be given to rather large $N_{D}$ values, both absolute and relative, that manifest the measure of the $p_{\mathrm{z}}$ odd electrons correlation. It should be added as well that the relation $N_{D}=2 \Delta \hat{\mathrm{S}}^{2}$, which is characteristic for spin contaminated solutions in the singlet state, is rigidly kept over all the molecules. The data are added by the magnetic constant $J$ determined following Eq. 3.

As seen in Table 1 , quantities $\Delta E^{\mathrm{RU}}, N_{D}$ and $\Delta\langle S\rangle^{2}$ gradually increase when the size grows due to increasing the number of atoms involved in the pristine structures. The relative parameters $\delta E^{\mathrm{RU}}$ and $\delta N_{D}$ only slightly depend on the NGr size just exhibiting a steady growth of the parameters. In contrast, $J$ values demonstrate quite different behavior. The values show a significant size-dependence, gradually decreasing by the absolute magnitude when the size grows. This dependence can be obviously interpreted as the indication of strengthening the electron correlation thus exhibiting the collective character of the event. The finding is expected to lay the foundation of peculiar size-effects for properties that are governed by these parameters, the first of which can be addressed to molecular ferrodiamagnetism. The diamagnetic behavior is provided by $\sigma$ electrons while the ferromagnetic contribution is relevant to odd $p_{\mathrm{z}}$ ones.

As mentioned earlier, the primitive cell of graphene crystal, which determines the magnetic properties of an ideal crystal, involves two atoms joined by one $C=C$ bond of a benzenoid unit. The estimation of the $|J|$ value for ethylene and benzene molecule with stretched $C=C$ bonds up to $1.42 \AA$ in length gives $|J|$ values of $13 \mathrm{kcal} / \mathrm{mol}$ and $16 \mathrm{kcal} / \mathrm{mol}$, respectively. Despite the fact that ethylene and benzene molecules do not reproduce this cell exactly, a similar $|J|$ constant of the cell is undoubted. Owing to this, the crystal should demonstrate the diamagnetic behaviour only. To provide a remarkable 'ferrodiamagnetism' means to drastically decrease the magnetic constant $|J|$. While this is impossible for a regular crystal, graphene molecules are more labile. Shown in Table 1, the smallest $|J|$ of $0.3 \mathrm{kcal} / \mathrm{mol}$ is still large enough to provide a recordable magnetization of $(15,12) \mathrm{NGr}$ molecular magnet, but the tendency is quite optimistic. Supposing the quantity to be inversely proportional to the number of odd electrons, it is possible to estimate the electron number which would satisfy $\left|J_{\text {crit }}\right|$ of $10^{-2}-10^{-3}$ $\mathrm{kcal} / \mathrm{mol}$ which gives us $N \sim 10^{5}$.

For rectangular NGrs $\mathrm{N}$ odd electrons are supplied by $\mathrm{N}$ carbon atoms that, according to [50], is determined as

$\mathrm{N}=2\left(n_{a} n_{z}+n_{a}+n_{z}\right)$.

To fit the needed $\mathrm{N}$ value, the indices $n_{a}$ and $n_{z}$ should be of hundreds, which leads to linear sizes of the NGrs from a few units to tens $\mathrm{nm}$. The estimation is rather approximate, but it, nevertheless, correlates well with the experimental observations of the ferromagnetism of activated carbon fibers consisting of nanographite domains of $\sim 2 \mathrm{~nm}$ in size [51] as well as with the data related to meshed graphene [43, 44] discussed earlier. The maximum effect was observed in [43] at the interpore distance of $20 \mathrm{~nm}$ after which the signal gradually decreased when the width increased. The behavior is similar to that obtained for fullerene oligomers [52], which led to the suggestion of a scaly mechanism of nanostructured solid state magnetism of the polymerized fullerene $C_{60}$ that was confirmed experimentally. 
The said above highlights another noteworthy aspect of the graphene magnetism attributing the phenomenon to size-dependent ones. The latter means that the graphene magnetization is observed for nanosize samples only, moreover, for samples whose linear dimensions fit a definite interval, while the phenomenon does not take place at either smaller or bigger samples size outside the critical region. Actually, an individual benzenoid unit (and benzene molecule) is only diamagnetic. When the units are joined to form a graphene-like benzenoid cluster, effectively unpaired electrons appear due to weakening the interaction between $p_{z}$ odd electrons followed by stretching $C=C$ bonds which causes the electrons correlation. The correlation accelerates when the cluster size increases, which is followed with the magnetic constant $|J|$ decreasing until the latter achieves a critical value that provides a noticeable fixation of the spin mixing of the cluster ground state. Until the enlargement of the cluster size violates a molecular (cluster-like) behavior of odd electrons, the sample magnetization will grow. However, as soon as the electron behavior becomes spatially quantized, the molecular character of the magnetization will be broken and will be substituted by one determined by the electron properties of the primitive cell. Critical size parameters, controlling quantization of molecular properties depends on the kind of quasiparticles being considered. Addressing graphene magnetization, evidently it is Dirac fermions that control the quantizing and their mean free path $l_{f m}$ determines the critical size parameter: when the cluster size exceeds $l_{f m}$ the spatial quantization quenches the cluster magnetization.

Happily, just recently experimental data were published related to the study of size dependence of both the linearity of the fermion low-energy band $E_{\mathrm{fm}}(k)$ within the Dirac cones in the vicinity of the Fermi level and the shape of the spectrum. Figure 8 presents a set of $E_{\mathrm{fm}}(k)$ spectra related to a

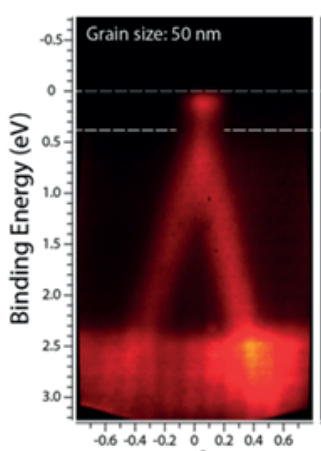

$\mathrm{k} \|\left(\AA^{-1}\right)$

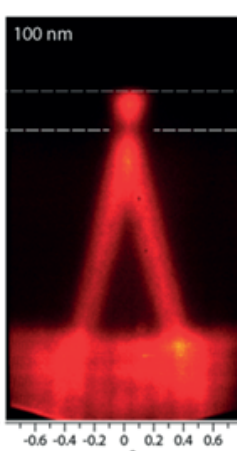

$\mathrm{k} \|^{-}\left(\AA^{-1}\right)$

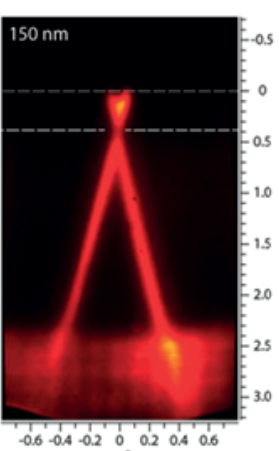

$\mathrm{k} \|\left(\AA^{-1}\right)$
Fig. 8. Dirac's cones of continuous graphene film with average grain sizes of 50,100, and $150 \mathrm{~nm}$ at the Kpoint of graphene Brillouin rone obtained by ARPES mapping. Fermi energy is settled to zero. Adapted from Ref. [54].

polycrystalline graphene sample consisting of grains of different sizes [53]. As seen in the figure, quantizing is well supported in grains of $150 \mathrm{~nm}$, starts to be distorted in grains of 100 $\mathrm{nm}$ and is remarkably violated for grains of 50 $\mathrm{nm}$. A considerable broadening of the spectrum in the last case allows putting the upper bound for $l_{\text {fm }}$ around $50 \mathrm{~nm}$. A comparable $l_{f m}$ value of $\sim 20 \mathrm{~nm}$ follows from the data related to COhexagon structure [19].

Obviously, the transition from localized to quantized state is not abrupt. Thus at the pore width $W=40 \mathrm{~nm}$ the residual magnetization only halves the maximum value at $20 \mathrm{~nm}$ (see inset in Fig. 7c) and continuous approaching zero may cover quite a large pore width. Actually, in the case of $\mathrm{MgO}$ pores [44], magnetization of rGO flakes with width $\sim 100$ nm constitutes $\sim 20 \%$ of the value at the pore width of $10 \mathrm{~nm}$. Nevertheless, the molecules linear size is evidently the governing factor for the magnitude of ferrodiamagnetism of pristine graphene.

\subsection{High-Temperature Ferromagnetic Topological Insulating Phase of Graphene} If the discussion in the previous section allows one to understand when the magnetic behavior of graphene becomes measurable, it, however, does not answer the question of why the behavior is ferromagnetic and still exists at and above room temperature. In fact, it is difficult to expect ferromagnetism from a species with 
zero total spin density in the ground state. Additionally, molecular magnetism is usually observed at quite low temperatures [48] and its fixation at room temperature seems highly unexpected. At the same time, there are physical objects for which high-temperature ferromagnetism is a characteristic mark. Thus, we come again to the peculiar Dirac materials known as TIs [34]. As shown in Section 4, quite considerable electron correlation and small, but available, intrinsic-dynamic SOC allow attributing graphene to weak QSHI. Evidently, the topological non-triviality is relevant to both crystalline and molecular graphene. Accepting this idea, let us see how it works with respect to the high-temperature ferromagnetism of graphene.

In view of electron correlation, graphene presents a honeycomb structure of carbon atoms with local spins distributed over them. The spin values are not integral and are determined by the relevant $N_{D A}$ values forming an image ACS map similar to the one presented in Fig. 4f. Evidently, the exchange interaction between these local spins is responsible for the magnetic behavior of graphene. To determine the type of the behavior, let us use the formalism suggested for describing the magnetic impurities on the surface of a topological insulator [54]. In the presence of magnetic impurity or local spins, the main Hamiltonian describing the TI band structure in the form of Eq. 2 is substituted by a new one

$$
H=h v_{F}(\boldsymbol{k} \times \hat{\boldsymbol{z}}) \cdot \boldsymbol{\sigma}-H_{e x},
$$

where $\mathrm{v}_{\mathrm{F}}$ is the Fermi velocity, $\hat{z}$ is the surface unit normal, $\sigma$ is the Dirac electron spin and

$$
H_{\mathrm{ex}}=\sum_{\gamma_{1}} J_{\mathrm{z}} s_{\mathrm{z}}(\mathbf{r}) S_{\mathrm{z}}(\mathbf{r})+J_{\mathrm{xy}}\left(s_{\mathrm{x}} S_{\mathrm{x}}+s_{\mathrm{y}} S_{\mathrm{y}}\right)
$$

Here $S_{i}(\mathbf{r})$ is the spin of a magnetic impurity located at $\mathbf{r}, s_{\mathrm{i}}(\mathbf{r})=\psi^{*}(\mathbf{r}) \sigma^{\mathrm{i}} \psi(\mathbf{r})$ is the spin of the surface electrons and $J_{z}$ and $J_{x y}$ are the coupling parameters. When the impurity spin is polarized in the $z$ direction the second term in Eq. 6 disappears. As every magnetic impurity opens a local gap in its vicinity, one may expect the system to be gapped everywhere, at least in the mean-field level. However, this is not necessarily true if the magnetization of magnetic impurities is non-uniform. Meeting the problem and comparing the formation of magnetic domain wall and ferromagnetic arrangement, the authors [54] came to the conclusion that the magnetic impurities must be ferromagnetically coupled.

Sharing this viewpoint, a similar Hamiltonian $H_{e x}$ was suggested to describe the Dirac-fermionmediated ferromagnetism in a topological insulator [55]. The Hamiltonian $H_{\mathrm{ex}}$ reads

$$
H_{e x}=J n_{s} \overline{S_{z}} \sigma_{z} \text {. }
$$

Here $\sigma_{z}$ is the z component of the electron spin and $n$ is the areal density of localized spins with an average $z$ component $\bar{S}_{z}$. J describes the exchange coupling between the $z$ components of the Dirac electron spin $\sigma$ and the local spin $\mathbf{S}$, locking $\sigma$ perpendicular to the momentum $\mathbf{k}$. Following the same conclusion that every local spin opens the gap and the system must be gapped everywhere, we have to accept the necessity of a ferromagnetic configuration for local spins. Apparently, it is the consequence that explains ferromagnetic behavior of pure graphene samples.

Highly convincing evidence, strongly supporting suggestion that graphene is a typical TI, was received in the most recent [56]. Figure 9 presents a molecular complex, presented by Er(trensal) single-ion magnets that was adsorbed on graphene/ $\mathrm{Ru}(0001)$, on graphene/ $\operatorname{Ir}(111)$ and on bare $\mathrm{Ru}(0001)$ substrates. On graphene, the molecules selfassemble into dense and well-ordered islands with their magnetic easy axes perpendicular to the surface. In contrast, on bare $\mathrm{Ru}(0001)$ the molecules are disordered exhibiting only weak directional preference of the easy magnetization axis. Accordingly, the ferromagnetic response is spin polarized in the two former cases while unpolarized in the case of the $\mathrm{Ru}(0001)$ substrate and additionally twice less by magnitude. Therefore, the 

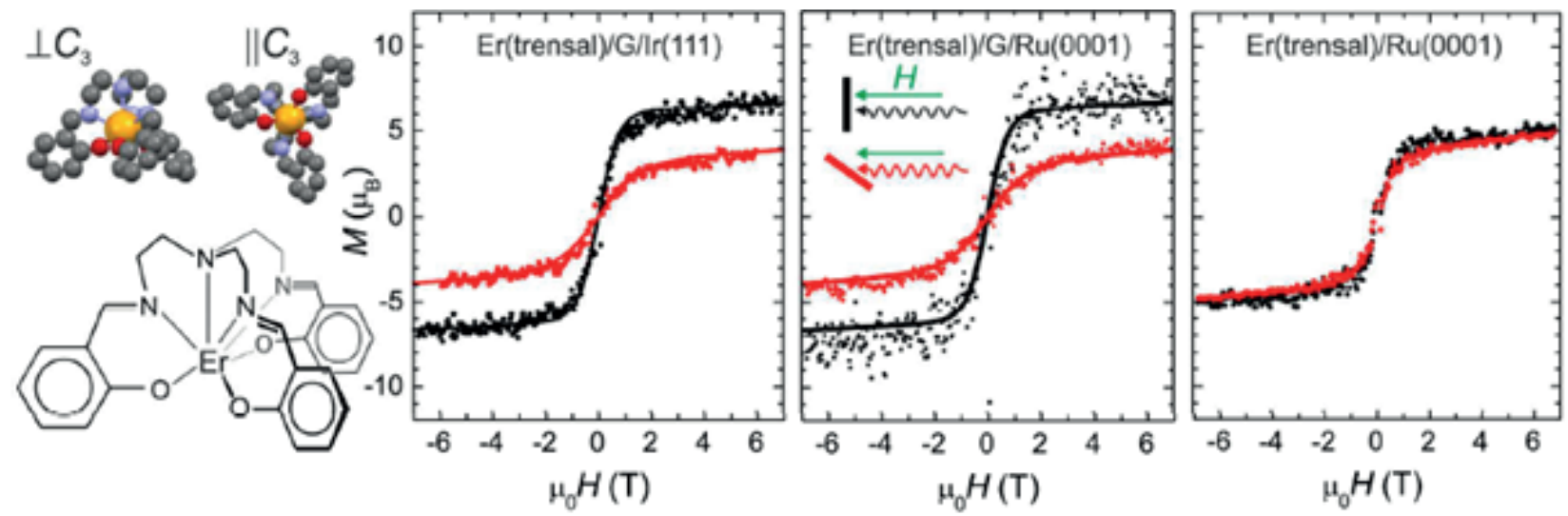

Fig. 9. Structural views and scheme of the molecular magnet Er(trensal). Coloring: orange: Er; blue: N; red: O; grey: C; $H$ atoms are omitted for clarity. From left to right: magnetization curves at normal (black) and grazing (red) orientation of magnetic field with respect to the substrate surface. Adapted from Ref. [56].

topologically trivial bare ruthenium surface has no effect on the molecular impurity ordering while the addition of a monolayer graphene covering leads to ferromagnetic ordering of the impurity characteristic for topologically non-trivial substrates, which were discussed above. Not only ordering but enhancement of ferromagnetic response evidences the TI nature of the graphene component of the hybrid substrates. In fact, the substitution of ruthenium by iridium has no additional effect so that all the observed peculiarities are caused by graphene layer. As for the response enhancement, $J_{z}\left\langle s_{z}\right\rangle$ in the right-hand part of Eq. 7 acts as an effective magnetic field to magnetize the magnetic impurities. At the same time, $J_{z}\left\langle s_{z}\right\rangle$ acts as the effective magnetic field to polarize the electron spin of TI. Obviously, such a double action of the exchange coupling leads to the enhancement of the magnetic response. When magnetic impurities form a continuous adlayer, additional enhancement should be expected due to the magnetic proximity effect (see the last publication [57] and references therein). Therefore, empirically confirmed graphene behaves as a typical TI, which leads to a severe reconsideration of its physical properties discussed mainly without taking into account this drastically important fact.

\section{LOCAL SPINS IN GRAPHENE MOLECULE LANDSCAPE}

The local spins of graphene, which are actively involved in the manifestation of its topological non-triviality discussed above, are associated with effectively unpaired $p_{z}$ electrons and are one of the most important consequences of the UHF formalism applied to the graphene molecule open-shell ground state [3]. As seen in Table 1, bare graphene molecules are characterized by rather large total numbers of such electrons $N_{D}$ that constitute more than one third of the total number of the odd $p_{z}$ electrons. It means that the molecules are strongly radicalized thus exhibiting high chemical activity. While the total number of effectively unpaired electrons is the quantitative measure of the activity of the whole molecule, or molecular chemical susceptibility (MCS) introduced in [58], their partitioning over molecule atoms describes the atomic chemical susceptibility (ACS) in terms of $N_{D A}$ due to which image maps of their distribution over atoms present a chemical portrait of the associated molecules [59]. Such maps of graphene molecules have a very particular, but therewith standard image which allows both disclosing the local spin distribution over atoms and considering chemical activity of the molecules at the quantitative level.

Figure 10 presents the $N_{D A}$ distribution (the ACS $N_{D A}$ image map below) over atoms of the $(11,11)$ NGr bare molecule. As seen in the 

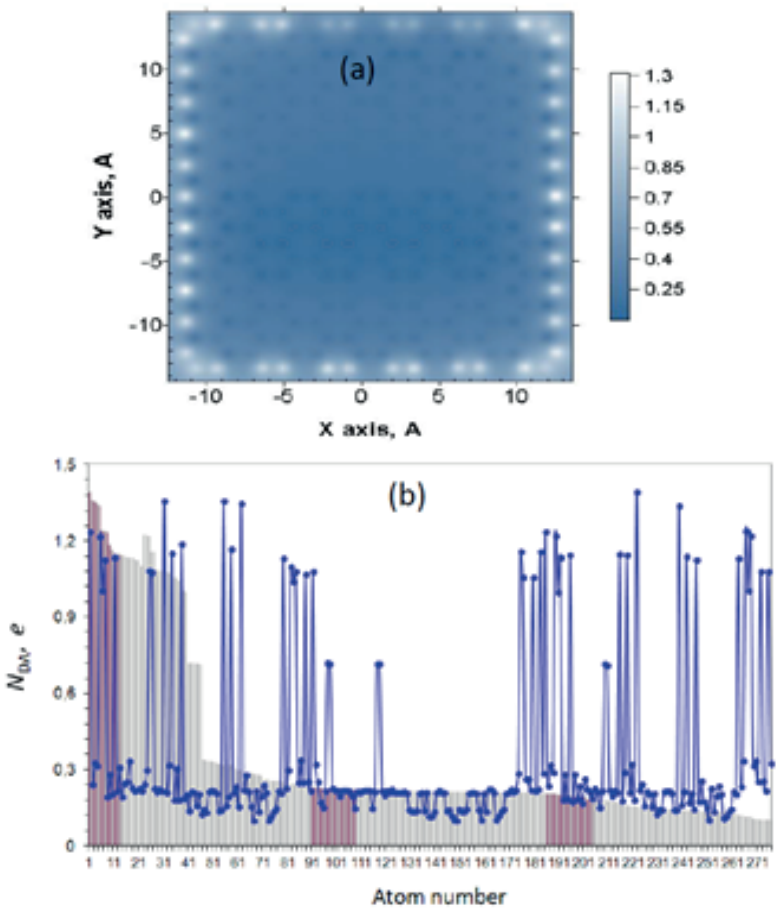

Fig. 10. (a) Equilibrium structure and $A C S N_{D A}$ image map of the $(11,11) N G r$ molecule with bare edges. Scale bar matches $N_{D A}$ values in e. (b) $N_{D A}$ plotting from output file (curve with dots) and max $\rightarrow$ min $N_{D A}$ distribution (bistogram). For the first 46 atoms: the histogram reveals first 22 zigzag edge atoms while next 24 bars (from 23 to 46) are related to armchair edge atoms. UHF AM1 calculations. figure, according to this parameter, the graphene molecule is definitely divided into two drastically different parts, namely, the circumference involving 46 edge atoms and internal honeycomb zone, or basal plane. Since the difference of the maximum $N_{D A}$ values in the two areas is six-fold, the basal plane is practically invisible in Fig. 10a, while keeping a considerable $N_{D A}$ of $\sim 0.2$ e in average. The value rising over the average occurs only for 40 atoms adjacent to the molecule perimeter of edge atoms, for which $N_{D A}$ varies from 0.34 e to $0.22 \mathrm{e}$. This atom fraction is clearly seen in the histogram in Fig. $10 b$ at atom numbers from 47 to 86 .

Presented in the figure is the chemical portrait of the bare $(11,11)$ NGr molecule. As seen from the histogram in Fig. 10b, the chemical activity of the graphene molecule atoms greatly varied within both the circumference and basal plane, more significantly within the first one. In the histogram the most intense 46 edge atoms belong to 22 and 24 atoms related to zigzag and armchair edges, respectively. For zigzag atoms $N_{D A}$ values fill the region $1.39-1.10 \mathrm{e}$, while the latter for armchair atoms is much wider and constitutes 1.22-0.71 e.

Qualitatively, the picture is typical for graphene sheets of any size. Modern fascinating experimental techniques allow confirming the above statement. Thus, as shown in [3, 7], the advanced atom-resolved AFM is able to fix local spins in a pentacene molecule when using a CO-terminated gold tip. Since this experiment provides monitoring of the molecule chemical activity, a close similarity of the AFM image and the relevant ACS $N_{D A}$ map occurred quite expected. Happily, such a justification is available now for $(n, 3)$ graphene nanoribbon as well [60]. As in the case of pentacene, the scanning transmission electron microscope (STEM) image of the nanoribbons (Figure 11a) is in good consent with the calculated $N_{D A}$ map of the (15, 3) NGr molecule (Fig. 11b) thus, in particular, evidently justifying a peculiar two-zone character of the graphene pool of effectively unpaired electrons.

The variety of electron densities of carbon atoms along and perpendicular to the edges of
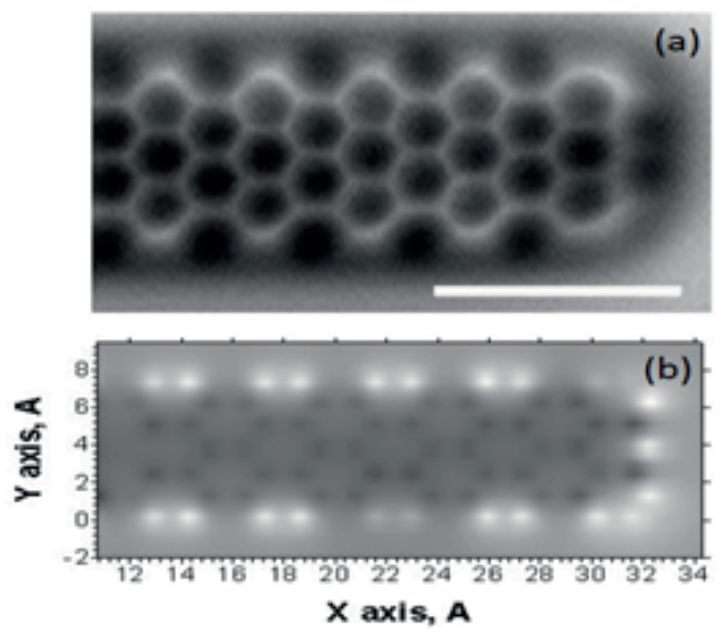

Fig. 11. (a) Constant-height high-resolution AFM image of the rigrag end of graphene nanoribbon obtained with COterminated tip. White scale bar: $1 \mathrm{~nm}$. Adapted from Ref. [64]. (b) $A C S N_{D A}$ image map of one of the rigzag ends of the $(15,3)$ NGr molecule with bare edges. UHF AM1 calculations. 
a graphene flake has been clearly demonstrated just recently by site-specific single-atom electron energy loss spectroscopy (EELS) using the annular dark field (ADF) mode of a low-voltage STEM [61]. Figure 12 discloses a highly informative picture related to the states of carbon atoms in the vicinity of zigzag and armchair edges. As seen in the figure, the site-dependent peculiarities are observed in the low-energy parts of the EELS spectra, which present $K$-edges of the carbon EELS signals. All the low-energy spectra involve a characteristic EELS peak $\mathrm{P}_{\mathrm{b}}$ at $285 \mathrm{eV}$ related to the excitation transformation of a core $s$-electron to an unoccupied $\sigma^{*}$ orbital. Additional peaks at $281 \mathrm{eV}\left(\mathrm{P}_{\mathrm{z}}\right)$ and $282.8 \mathrm{eV}\left(\mathrm{P}_{\mathrm{a}}\right)$ for the zigzag and armchair edge atoms, respectively, are caused by the s electron excitation to an unoccupied $p_{\mathrm{z}}^{*}$ orbital and the change to the profile of the EELS is related to variations in the local density of states. The peaks are well pronounced for edge atoms (spectrum 1), significantly decreasing in intensity for adjacent atoms (spectrum 2) and practically fully vanishing for carbon atoms on the
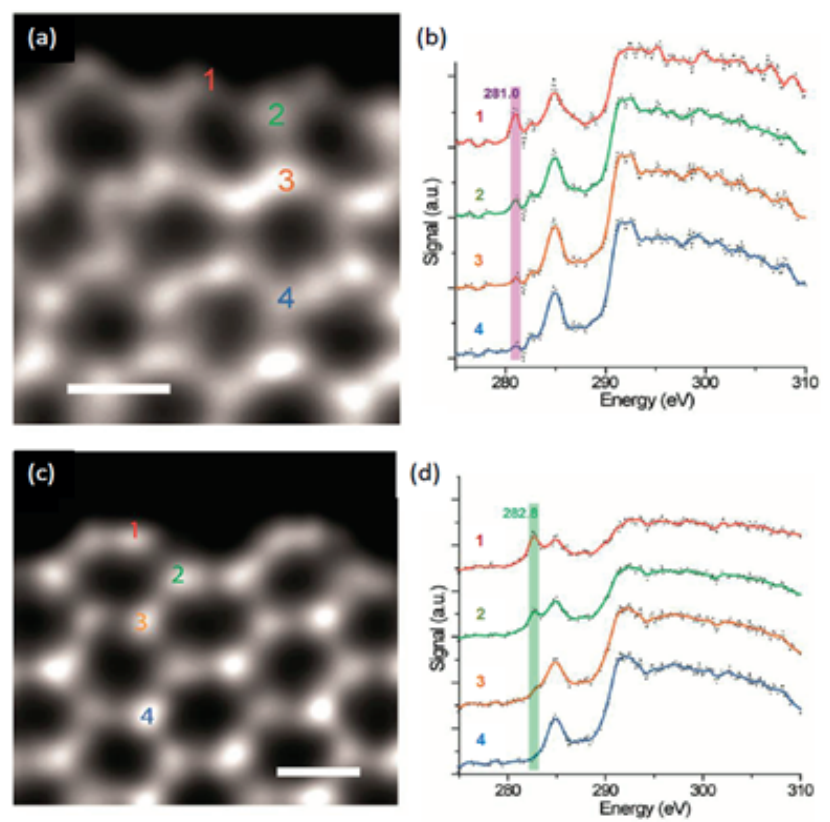

Fig. 12. STEM: EELS mapping of graphene edges. (a) ADFSTEM image and (b) EELS of rigrag edge from the regions numbered in (a). (c) ADF-STEM image and (d) EELS of armchair edge from the regions numbered in (d). White scale bar: 2 A. Numbers and their colors on ADF-STEM images and EELS spectra coincide. Adapted from Ref. [61]. flake basal plane (spectra 3 and 4). Additionally, EELS spectra across the edge vary markedly for both zigzag and armchair atoms. As seen in Figure 13a, the spectra of two neighboring zigzag atoms (8 and 10) differ so greatly that the peak $\mathrm{P}_{z}$ is substituted by the peak $\mathrm{P}$. The latter structure is conserved for the adjacent atom 9, albeit with changes in the intensity distribution between $\mathrm{P}_{a}$ and $\mathrm{P}_{\mathrm{b}}$ peaks. EELS spectra in Fig. $13 b$ exhibit the difference in the behavior of the neighboring armchair atoms expressed in changing the $\mathrm{P}_{\mathrm{a}} / \mathrm{P}_{\mathrm{b}}$ intensities ratio.

The discussed spectral features are well consistent with the conclusion obtained from the above analysis of the $N_{D A}$ distribution in Fig. 10b. Thus, first, the chemical bonding of zigzag and armchair edge atoms is different, bigger in the latter case, which is consistent with the lower chemical activity of the armchair edge atoms compared with the zigzag ones. Second, atoms of the adjacent-to-edge rows demonstrate a transient state between the edge and bulk one that correlates well with the activity of 40

(a)
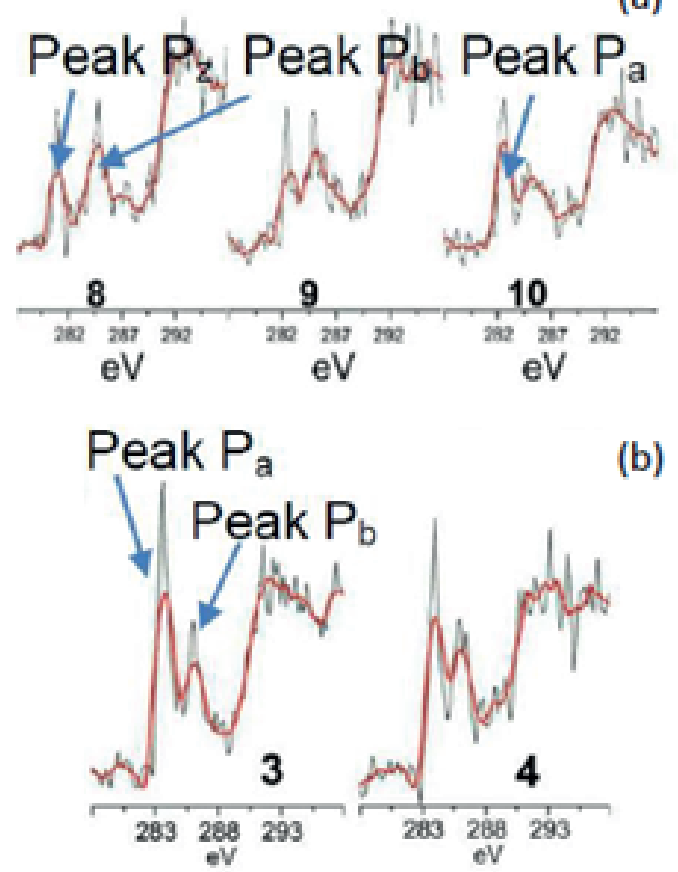

(b)

Fig. 13. EELS spectra at the edges of graphene flake. (a) Neighboring rigzag atoms (atoms 8 and 9) and adjacent atom between them (atom 9). (b) Neighboring armchair atoms (atoms 3 and 4). $P, P_{a}$ and $P_{b}$ match peaks at $281 \mathrm{eV}, 282.8 \mathrm{eV}$, and $285 \mathrm{eV}$, respectively. Adapted from Ref. [61]. 
adjacent atoms (from 47 to 86) in the histogram in Fig. 10b. Third, inside the region, the perimeter of which is formed by adjacent atoms, the carbon atoms can be attributed to the basalplane ones. Fourth, the electron density as well as ACS $N_{D A}$ of the edge, adjacent, and bulk atoms significantly varies thus demonstrating that the atom groups are not rigidly standardized and might be very sensitive to external actions due to which graphene molecules are very changeable.

The two-zone electron density image of bare graphene molecule is not new. This feature lays the foundation of a large number of theoreticalcomputational considerations concerning the particular role of edge atoms in graphene begun in 1996 [62] and lasting until today (see a collection of papers [63-66] and references therein). The graphene objects studied were mainly pencil-made with a regular honeycomb structure described by standard $C=C$ bonds of $1.42 \AA$ in length and identical zigzag and armchair edge atoms. The results obtained concern the two-zone electronic structure and the attribution of the edge atoms peculiarity to the expected particular magnetic behavior of graphene flakes and, particularly, nanoribbons. However, the latter expectations proved quite illusive and as shown experimentally, the magnetic behavior of graphene samples is not directly connected with peculiar features of their edge atoms. It is worthwhile to keep in mind a skeptical comment of Roald Hoffmann concerning his "Small but strong lessons from chemistry to nanoscience" [67]: "There is a special problem that theory has with unterminated structures - ribbons cut off on the sides, polymers lacking ends. If passivation is not chosen as a strategy, then the radical lobes of the unterminated carbon atoms, or undercoordinated transition metals, will generate states that are roughly in the middle energetically, above filled levels, below empty levels in a typical molecule that has a substantial gap between filled and unfilled levels. If such levels - states, the physicists call them - are not identified as "intruder" states, not really real, but arising from the artifact of termination, they may be mistaken for real states in the band gap, important electronically. And if electrons are placed in them, there is no end to the trouble one can get into. These band gap states are, of course, the origin of the reactivity of the terminated but not passivated point, line, or plane. But they have little to do with the fundamental electronic structure of the material".

\section{INTRODUCTION TO GRAPHENE COMPUTATIONAL SPIN CHEMISTRY}

Modern chemistry is heavily occupied with revealing reliable qualitative and better quantitative descriptors which can point to the consequences of chemical reactions. UHF formalism of open-shell molecules suggests unique quantitative descriptors MCS $N_{D}$ and ACS $N_{D A}$. For molecules with even number of electrons $N_{D A}$ is identical to the atom free valence [68]. Consequently, free valence of atom $A, V_{A}^{\text {free }}$, is defined as

$V_{A}^{\text {free }}=N_{A}^{v a l}-\Sigma_{B \neq A} K_{A B}$.

Here $N_{A}^{v a l}$ is the number of valence electrons of atom $\mathrm{A}$ and $\sum_{(\mathrm{B} \neq \mathrm{A})} K_{\mathrm{AB}}$ presents a sum over the generalized bond index

\section{$K_{\mathrm{AB}}=\left|P_{\mathrm{AB}}\right|^{2}+\left|D_{\mathrm{AB}}\right|^{2}$,}

where the first term is the Wiberg bond index while the second term is determined by taking into account the spin density matrix. The $V_{A}^{\text {free }}$ distribution (curve with dots) alongside with the $\operatorname{ACS} N_{D A}$ (histogram) for the $(5,5)$ NGr molecule is shown in Figure 14. As seen in the figure, the

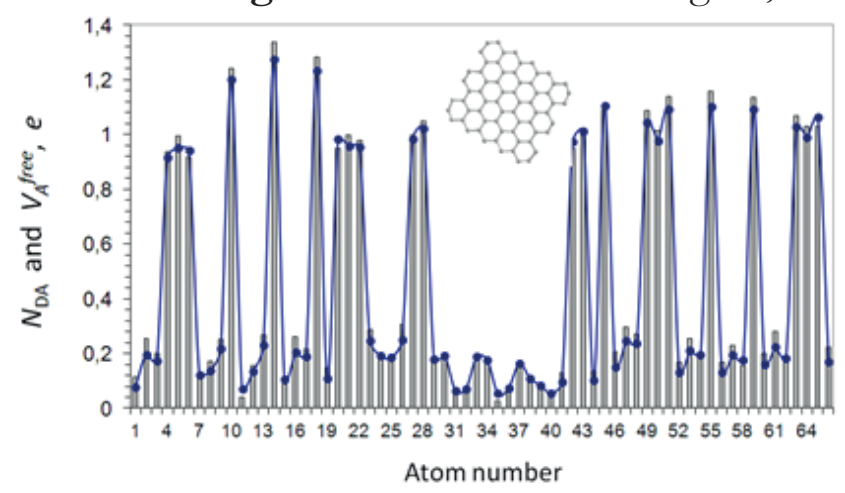

Fig. 14. ACS $N_{D A}$ (bistogram) and free valence $V_{A}^{\text {free }}$ (curve with dots) distributions over atoms of the $(5,5) \mathrm{NGr}$ molecule. Inset: equilibrium structure of the $(5,5) \mathrm{NGr}$ molecule. UHF AM1 calculations. 
first steps of any chemical reaction occur at the molecule periphery. Since this reactivity area is largely spread in space, the formation of the first monoderivative does not inhibit the molecule reactivity so that the reaction will continue until the reaction ability is satisfied. This means that any chemical modification of graphene starts as polyderivatization of the pristine molecule at its circumference.

The excellent agreement of $N_{D A}$ and $V_{A}^{\text {free }}$ values shows that the former is actually a quantitative ACS measure and can serve a quantitative descriptor of the molecule target atoms, for which atom-atom contacts are the most desirable in addition reactions. Thus, the values distribution over molecule atoms forms a unique $\operatorname{ACS} N_{D A}$ map, which opens a transparent methodology of a successive algorithmic computational synthesis of any graphene polyderivatives, just selecting the graphene core atom at each step by the largest $N_{D A}$ value. A successive use of this methodology was shown on examples of the hydrogenation [69] and oxidation [70] of the $(5,5)$ NGr molecule.

As it turns out, already the first addition of any reactant, or modifier, to the edge atom of graphene molecule, chosen by the highest ACS, causes a considerable change in the pristine ACS $N_{D A}$ image map thus allowing the exhibition of the second edge atom with the highest ACS to proceed with the chemical modification and so forth. This behavior is common to graphene molecules of any size and shape. In what follows, the behavior feature will be demonstrated on the example of the (5, 5) NGr molecule that was chosen to simplify the further presentation. Figure $\mathbf{1 5}$ presents a set of $(5,5) \mathrm{NGr}$ polyhydrides and polyoxides obtained in the course of the first stage of the relevant per step reactions that concern framing the bare molecule. Two important conclusions follow from the figure. First, in spite of the seemingly local change of the molecule structure caused by the addition, the second target carbon atoms does not correspond to the atom that

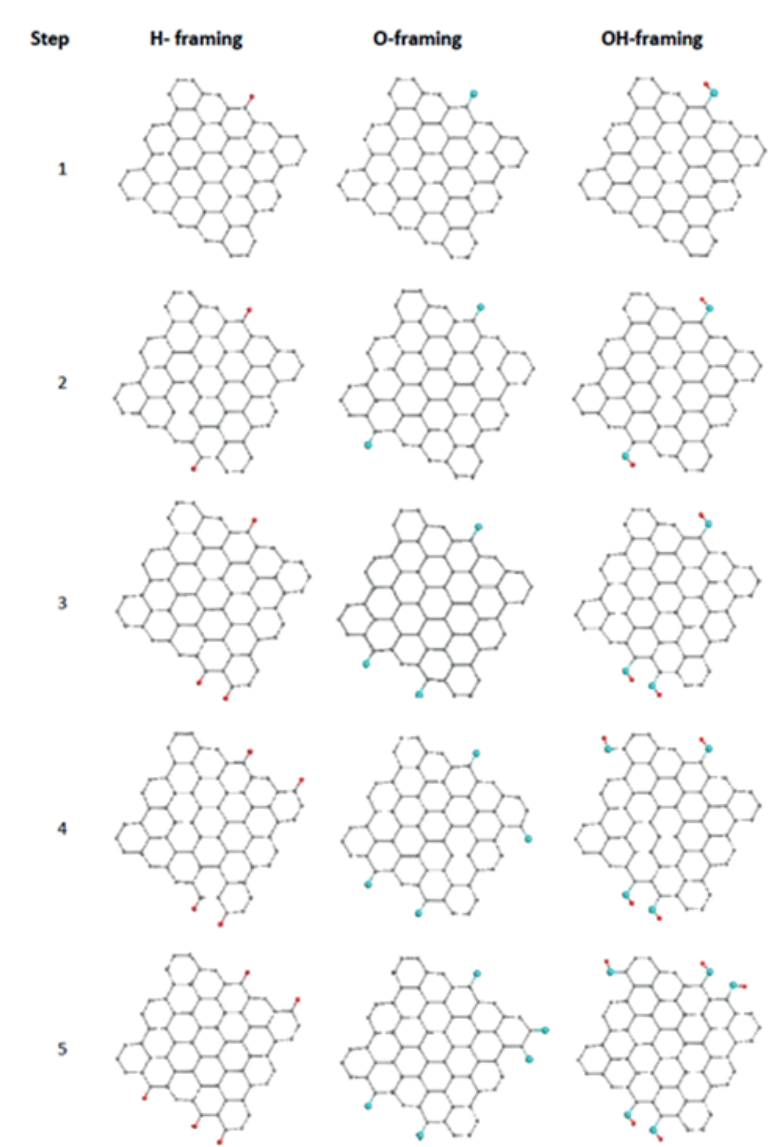

Fig. 15. Equilibrium structures of the (5,5) NGrpolybydrides and polyoxides related to $1 \mathrm{st}, 2 \mathrm{nd}, 3 \mathrm{rd}$, 4th, and 5 th steps obtained in the course of the relevant stepwise reactions. Gray, blue, and red balls mark carbon, oxygen, and bydrogen atoms, respectively. UHF AM1 calculations.

is the second one of the highest activity in the $N_{D A}$ list of the pristine molecule. Second, this atom position, as well as the sequence of steps, varies depending on the chemical nature of the addends. Both features are the result of the redistribution of $C=C$ bond lengths over the molecule, thus revealing the collective action of its unpaired electrons and/or local spins.

\section{COMMENTS ON CONVERTING GRAPHENE FROM SEMIMETAL TO SEMICONDUCTOR}

Despite its numerous extraordinary properties and huge potential for various applications, one of the greatest challenges in using graphene as an electronic material is the lack of a sizable bandgap. Accordingly, graphene is intrinsically a zero-gap QSHI, but a semimetal in the view of most. The gap absence significantly limits the use of graphene in many applications where 
semiconducting materials with a suitable bandgap are required. Researchers have been searching for effective ways to produce semiconducting graphene and have developed various methods to generate a bandgap in graphene. Despite extensive investigation in the laboratory, the production of semiconducting graphene still faces many challenges. A detailed description of problems on the way as well as suggestions for their resolving is given in review [71]. Let us look at the problems from the viewpoint of obvious 'underwater stones' provided by the common properties of the graphene chemistry.

When categorizing methods to produce semiconducting graphene, three groups were classified: (1) morphological patterning of graphene sheets into nanoribbons, nanomeshes, or quantum dots to induce quantum confinement and edge effects; (2) chemical modification, doping, or surface functionalization of graphene to intentionally interrupt the connectivity of the $\pi$ electron network; and (3) other methods, e.g., use of two graphene layers arranged in Bernal stacking (or $\mathrm{AB}$ stacking) to break the lattice symmetry, and applying mechanical deformation or strain to graphene.

Following the scheme proposed in [71] and shown in Figure 16, techniques of the first group meet problems concerning the basic edge property of the graphene molecule that is obviously a dangling-bond effect. Actually, cutting graphene sheets into nanoribbons increases the number of dangling bonds and, consequently, the number of unpaired

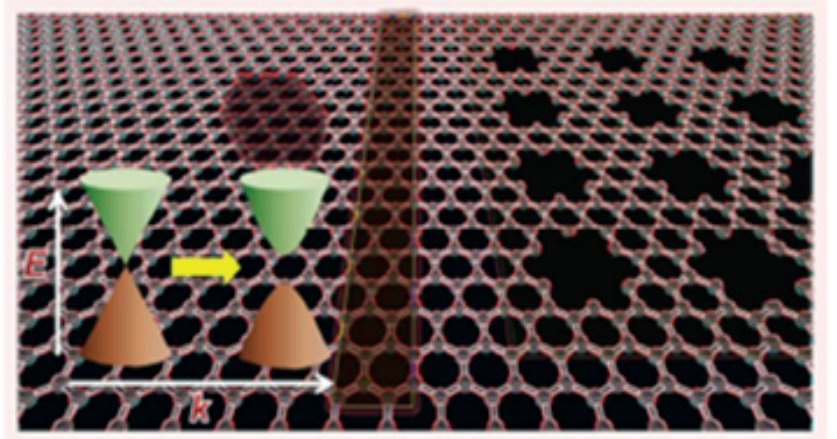

Fig. 16. A schematic view of morphological patterning of a graphene sheet. Adapted from Ref. [71]. electrons $N_{D}$ thus enhancing the ribbon's radical properties. In its turn, the extra radicalization greatly promotes various chemical reactions in the ribbon's circumference leading to a significant and sometimes even drastic reconstruction of the pristine graphene structure. Inserting nanomeshes results in the same effect due to the highly active periphery of the formed holes. Deposition of nanosize quantum dots highly disturbs the graphene substrate, changing the $C=C$ bond length distribution, and thus causing the $N_{D}$ growth if even not contributing by their own unpaired electrons. Therefore, cutting and drilling create a big 'edges problem' and do not seem to be proper technologies for the desired transformation of the graphene electronic system.

The chemical modification of graphene is not only a subject of interesting chemistry but has been repeatedly suggested as an efficient tool for the semimetal-semiconductor transferring needed for high-performance electronics [71]. It should be noted that these suggestions are based on results of computational studies that concern pencil-drawn pictures of graphene fragments including those or other chemical modifiers artificially spread over graphene sheets (see, for example, Refs. [72] and [73]). These and many other virtual structures, regularly distributed in space by applying periodic boundary conditions, exhibit electronic properties that are so badly needed for the application. However, the empirical reality is much less promising since so far none of regularly chemically modified graphene structure has been obtained. And the collective behavior of graphene unpaired electrons, protesting against any response localization, is the main reason for the failure.

The desired regular structures of chemically modified graphene are related to the graphene polyderivatives that are formed with the participation of carbon atoms on the basal plane. However, as was shown earlier, reactions at the circumference precede those at the basal plane. Moreover, the latter cannot begin until 
the former are completed. In the predominant majority of the studied cases, the completion of the circumference reactions means the completion of framing of the studied molecules. A thorough study of the circumference reactions has disclosed a very exciting feature: the framing of graphene molecules promotes the molecule cracking. Figure 17 presents a set of ACS $N_{D A}$ maps related to mono-hydrogen terminated $\left(H_{1}-\right.$ terminated below) NGr molecules of different sizes. The ACS maps of all the pristine molecules are of an identical pattern characteristic for the $(11,11)$ NGr molecule shown in Fig. 10 just scaled according to the molecule size. As seen in the figure, the ACS maps of $H_{1}$-terminated polyderivatives show a peculiar two-part division related to $(15,12)\left(3.275 \times 2.957 \mathrm{~nm}^{2}\right)$ and $(11,11)$ $\left(2.698 \times 2.404 \mathrm{~nm}^{2}\right) \mathrm{NGr}$ molecules in contrast to the maps of $(9,9)\left(1.994 \times 2.214 \mathrm{~nm}^{2}\right),(7,7)$
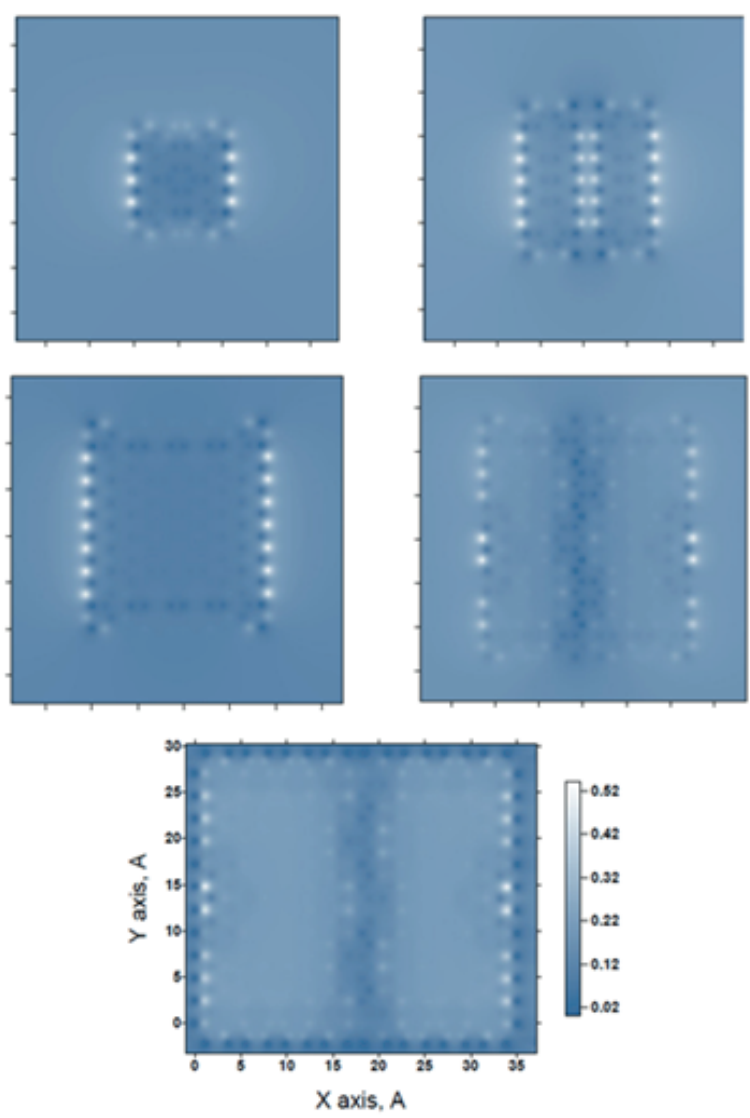

Fig. 17. ACS $N_{D A}$ image maps over atoms of the (5, 5), (7, 7), (9, 9), (11, 11), and $(15,12) \mathrm{NGr}$ molecules with $H_{1}$ terminated edges. All the images are given in the same space and $N_{D A}$ scales shown on the bottom. UHF AM1 calculations. $\left(1.574 \times 1.721 \mathrm{~nm}^{2}\right)$, and $(5,5)\left(1.121 \times 1.219 \mathrm{~nm}^{2}\right)$ NGr molecules. Apparently, the finding demonstrates the ability of graphene molecules to be divided when their linear size exceeds 1-2 nm. The cracking of pristine graphene sheets in the course of chemical reaction, particularly during oxidation, was repeatedly observed. A peculiar size effect was studied for graphene oxidation in [74] and fluorination in [75]. During $900 \mathrm{sec}$ of continuous oxidation, micrometer graphene sheets were transformed into $\sim 1 \mathrm{~nm}$ pieces of graphene oxide. Obviously, the tempo of cracking should depend on particular reaction conditions, including principal and service reactants, solvents, temperature, and so forth (see $[76,77])$. Probably, in some cases, cracking can be avoided. Apparently, this may depend on particular conditions of the inhibition of the edge atoms reactivity. However, its ability caused by the inner essence of the electron correlation is an imminent threat to the stability and integrity of the final product.

In some cases, the cracking is not observed when graphene samples present membranes fixed over their perimeter on solid substrates. Therewith, the reactivity of circumference atoms is inhibited and the basal plane is the main battlefield for the chemical modification. Still, as in the case of circumference reactions considered earlier, the highest ACS retains its role as a pointer of the target carbon atoms for the subsequent reaction steps. However, the situation is much more complicated from the structural aspect viewpoint. The addition of any modifier to the carbon atom on the basal plane is accompanied by the $s p^{2} \rightarrow s p^{3}$ transformation of the valence electrons hybridization so that for regularly packed chemical derivatives, the benzenoid skeleton of pristine graphene should be substituted with the cyclohexanoid one related to the formed polyderivatives. When benzene molecules and, subsequently, benzenoid units are monomorphic, cyclohexanes, and thus cyclohexanoid units, are highly heteromorphic. Not very big difference in the conformers free 
energy allows coexisting cyclohexanoids of different structures thus making the formation of a regular structure a rare event. Actually, the regular crystalline-like structure of a graphene polyhydride, known as graphane, was obtained experimentally under particular conditions only when hydrogenating fixed graphene membranes accessible to hydrogen atoms from both sides [78]. In the same experiment, fixed membranes accessible to hydrogen atoms from one side showed an irregular amorphous-like structure. The empirical findings were supported by computations based on the consideration of stepwise hydrogenation of fixed and free standing membranes accessible to hydrogen atom from either two or one sides [69].

As shown above, it is possible to proceed with the chemical modification of graphene within the basal plane only after a complete inhibition of high chemical activity of atoms at the circumference. Despite the fact that the $N_{D A}$ values within the area are much less than at a bare circumference, as seen in Fig. 10b, they still constitute $\sim 0.3-0.1$ e that is quite enough to maintain active chemical modification. However, the reality drastically differs from the desired chemical pattering of graphene sheets whose virtual image presents the final product of the pattering as regular carpets similar to the flowerbeds of French parks. The reality is more severe and closer to designs characteristic of English parks. The matter is that the collective of unpaired electrons, which strictly controls the chemical process at each step, has no means by which to predict the modifier deposition sites many steps forward. And it is clear why. Each event of the modifier deposition causes an unavoidable structure deformation due to local $s p^{2} \rightarrow s p^{3}$ transformation in the place of its contact with graphene. The relaxation of the deformation, as was seen in Fig. 15, extends over a large area, which, in turn, is accompanied by the redistribution of $C=C$ bond lengths. Trying to construct a pattering, it is impossible, while not making calculations, to guess exactly at which carbon atom the maximum reactivity will concentrate, highlighting the latter as a target atom to the next deposition. Therefore, even two simultaneous depositions cannot be predicted, not to mention such complex as quantum dots or nanoribbons. That is why a desired regular chemical pattering of graphene basal plane exists only virtually. The real situation was studied in detail in the case of graphene hydrogenation [79], exhibiting the gradual filling of the basal plane with hydrogen at random. Final products of the addition reactions on basal planes of graphene strongly depend on the addends being used. None of the regular motives were observed in any of the cases in the course of stepwise reactions.

As for use of graphene bi- and multilayers and applying mechanical deformation or strain to graphene, each of the techniques has its own limitations since again any structural changing affects the pool of effectively unpaired electrons (local spins) whose reaction is complex and nonlocal as well as practically unpredictable.

\section{CONCLUSION}

Graphene is a deeply spin-rooted species, starting with the quasi-relativistic description of the electronic state of graphene's hexagonal honeycomb structure and finishing with topological non-triviality of graphene crystals and molecules. The latter is convincingly supported by the magnetic behavior of graphene molecules and is the consequence of local spin emergence over carbon atoms subordinated to zero spin density of the species. Local spins form the groundwork for a computational spin chemistry of graphene and free from the illusions associated with the tuned morphological and chemical modification of graphene towards its converting from gapless QSHI to semiconductor.

\section{ACKNOWLEDGEMENTS}

The author takes the opportunity to express her deep gratitude to I.S. Burmistrov and Yu.E. Lozovik for fruitful and stimulating discussions. 


\section{REFERENCES}

1. Graphene Science Handbook: 6-volume set. Eds. Aliofkhazraei M, Ali N, Miln WI, Ozkan CS, Mitura S, Gervasoni J. CRC Press, Taylor and Francis Group, Boca Raton, 2016.

2. Löwdin P-O. Correlation problem in manyelectron quantum mechanics. 1. Review of different approaches and discussion of some current ideas. Adv. Chem. Phys., 1958, 2:209-322.

3. Sheka EF. The uniqueness of physical and chemical natures of graphene: Their coherence and conflicts. Int. J. Quant. Chem., 2014, 114:1079-1095.

4. Sheka EF. Computational strategy for graphene: Insight from odd electrons correlation. Int. J. Quant. Chem., 2012, 112:3076-3090.

5. Sheka EF, Chernozatonskii LA. Chemical reactivity and magnetism of graphene. Int. J. Quant. Chem., 2010, 110:1938-1946.

6. Sheka EF, Popova NA, Popova VA, Nikitina EA, Shaymardanova LKh. Structure-sensitive mechanism of nanographene failure. J. Exp. Theor. Phys., 2011, 112:602-611.

7. Sheka EF. Spin effects of $s p^{2}$ nanocarbons in light of unrestricted Hartree-Fock approach and spinorbit coupling theory. In: Advances in Quantum Methods and Applications in Chemistry, Physics, and Biology (Tadjer, A., Brändas, E.J., Maruani, J., Delgado-Barrio, G., ed.). Progress in Theoretical Chemistry and Physics 31, Springer, Switzerland, 2016:xxx-yyy.

8. Wallace PR. The band theory of graphite. Phys. Rev., 1947, 71:622-634.

9. Kane CL, Mele EJ. Quantum spin Hall effect in graphene. Phys. Rev. Lett., 2005, 95:226801.

10. Guzmàn-Verri GG. Electronic Properties of Silicon-Based Nanostructures. MS thesis, Wright State University, Dayton, 2006.

11. Slonczewski JC, Weiss PR. Band structure of graphite. Phys. Rev., 1957, 109:272-279.

12. Katsnelson MI. Graphene: carbon in two dimensions. Materials Today, 2007, 10:20-27.

13. Geim AK, Novoselov KS. The rise of graphene. Nat. Mat., 2007, 6:183-191.

14. Kim P. Graphene and relativistic quantum physics. Matiere de Dirac, Seminaire Poincare XVIII, 2014:1-21.

15. Hwang C, Siegel DA, Mo S-K, Regan W, Ismach A, Zhang Y, Zettl A, Lanzara A. Fermi velocity engineering in graphene by substrate modification. Sci. Rep., 2012, 2:590.

16. Kara A, Enriquez H, Seitsonen AP, Lew Yan Voon LC, Vizzini S, Aufray B, Oughaddou H. A review on silicene - new candidate for electronics. Surf Sci. Rep., 2012, 67:1-18.

17. Sheka EF. Silicene is a material phantom. Nanosyst. Phys. Chem. Math., 2016, 7:983-1001.

18. Zhang R-W, Ji W-X, Zhang C-W, Li P, Wang P-J. Prediction of flatness-driven quantum spin Hall effect in functionalized germanene and stanene. Phys. Chem. Chem. Phys., 2016, 18:28134-28139.

19. Gomes KK, Mar W, Ko W, Guinea F, Manoharan HC. Designer Dirac fermions and topological phases in molecular graphene. Nature, 2012, 483:307-311.

20. Tarruell L, Greif D, Uehlinger T, Jotzu G, Esslinger T. (2012). Creating, moving and merging Dirac points with a Fermi gas in a tunable honeycomb lattice. Nature, 2012, 483:302-306.

21. Bhimanapati GR, Lin Z, Meunier V, Jung Y, Cha J, Das S, Xiao D, Son Y, Strano MS, Cooper VR, Liang L, Louie SG, Ringe E, Zhou W, Sumpter BG, Terrones H, Xia F, Wang Y, Zhu J, Akinwande D, Alem N, Schuller JA, Schaak RE, Terrones M, Robinson JA. (2015). Recent advances in two-dimensional materials beyond graphene, ACS Nano, 2015, 9:11509-11539.

22. Xu L-C, Du A, Kou L. Hydrogenated borophene as a stable two-dimensional Dirac material with an ultrahigh Fermi velocity. Phys. Chem. Chem. Phys., 2016, 18:27284-27289.

23. Wang C, Xia Q, Nie Y, Rahman M, Guo G. Strain engineering band gap, effective mass and anisotropic Dirac-like cone in monolayer arsenene. AIP Advances, 2016, 6:035204.

24. Wang A, Zhang X, Zhao M. Topological insulator states in a honeycomb lattice of s-triazines. Nanoscale, 2014, 6:11157-11162.

25. Zhang X, Wang A, Zhao M. Spin-gapless semiconducting graphitic carbon nitrides: A theoretical design from first principles. Carbon, 2015, 84:1-8.

26. Wei L, Zhang X, Zhao M. Spin-polarized Dirac cones and topological nontriviality in a metalorganic framework $\mathrm{Ni}_{2} \mathrm{C}_{24} \mathrm{~S}_{6} \mathrm{H}_{12}$. Phys. Chem. Chem. Phys., 2016, 18:8059-8064. 
27. Zhang H, Li Y, Hou J, Du A, Chen Z. Dirac state in the $\mathrm{FeB}_{2}$ monolayer with graphene-like boron sheet. Nano Lett., 2016, 16:6124-6129.

28. Si C, Jin K-H, Zhou J, Sun Z, Liu F. Large-gap quantum spin hall state in MXenes: d-Band topological order in a triangular lattice. Nano Lett., 2016, DOI: 10.1021/acs.nanolett.6b03118.

29. Naguib M, Mochalin VN, Barsoum MW, Gogotsi Y. 25th Anniversary Article: MXenes: A new family of two-dimensional materials. Adv. Mat., 2014, 26:992-1005.

30. Bandurin DA, Tyurnina AV, Yu GL, Mishchenko A, Zólyomi V, Morozov SV, Kumar RK, Gorbachev RV, Kudrynskyi ZR, Pezzini S, Kovalyuk ZD, Zeitler U, Novoselov KS, Patanè A, Eaves L, Grigorieva IV, Fal'ko VI, Geim AK, Cao Y. High electron mobility, quantum Hall effect and anomalous optical response in atomically thin InSe. Nat. Nanotech., 2016, DOI: 10.1038/ NNANO.2016.242.

31. Sheka EF. Stretching and breaking of chemical nonds, correlation of electrons, and radical properties of covalent species, Adv. Quant. Chem., 2015, 70:111-161.

32. Hohenadler M, Assaad FF. Correlation effects in two-dimensional topological insulators, J. Phys.: Condens. Matter, 2013, 25:143201 (31pp).

33. Mayorov AS, Elias DC, Mukhin IS, Morozov SV, Ponomarenko LA, Novoselov KS, Geim AK, Gorbachev RV. How close can one approach the Dirac point in graphene experimentally? Nano Letters, 2012, 12:4629-4634.

34. Topological Insulators: Fundamentals and Perspective. Eds. Ortmann F, Roche S, Valenzuela SO, Molenkamp LW. Wiley: Chichester, 2015.

35. Schüler M, Rösner M, Wehling TO, Lichtenstein AI, Katsnelson MI. Optimal Hubbard models for materials with nonlocal Coulomb interactions: graphene, silicene and benzene. Phys. Rev. Lett., 2013, 111:036601.

36. Bučinský L, Malček M, Biskupič S, Jayatilaka D, Büchel GE, Arion VB. Spin contamination analogy, Kramers pairs symmetry and spin density representations at the 2-component unrestricted Hartree-Fock level of theory. Comp. Theor. Chem., 2015, 1065:27-41.
37. Yazyev OV. Emergence of magnetism in graphene materials and nanostructures. Rep. Prog. Phys., 2010, 73:05650130.

38. Esquinazi P, Spemann D, Hohne R, Setzer A, Han KH, Butz T. Induced magnetic ordering by proton irradiation in graphite. Phys. Rev. Lett., 2003, 91:227201.

39. Sepioni M, Nair RR, Rablen S, Narayanan J, Tuna F, Winpenny R, Geim AK, Grigorieva IV. Limits on intrinsic magnetism in graphene, Phys. Rev. Lett., 2010, 105:207205.

40. Nair RR, Sepioni M, Tsai I-L, Lehtinen O, Keinonen J, Krasheninnikov AV, Thomson T, Geim AK, Grigorieva IV. Spin-half paramagnetism in graphene induced by point defects. Nat. Phys., 2012, 8:199-202.

41. Eng AYS, Poh HL, Sanek F, Marysko M, Matejkova S, Sofer Z. Pumera M. Searching for magnetism in hydrogenated graphene: Using highly hydrogenated graphene prepared via birch reduction of graphite oxides. ACS Nano, 2013, 7:5930-5939.

42. Nair RR, Tsai I-L, Sepioni M, Lehtinen O, Keinonen J, Krasheninnikov AV, Castro Neto AH, Katsnelson MI, Geim AK, Grigorieva IV. Dual origin of defect magnetism in graphene and its reversible switching by molecular doping. Nat. Commn., 2013, 4:2010.

43. Tada K, Haruyama J, Yang HX, Chshiev M, Matsui T, Fukuyama H. Ferromagnetism in hydrogenated graphene nanopore arrays.Phys. Rev. Lett., 2011, 107:217203.

44. Ning G, Xu C, Hao L, Kazakova O, Fan Z, Wang H, Wang K, Gao J, Qian W, Wei F. Ferromagnetism in nanomesh graphene. Carbon, 2013, 51:390-396.

45. Van Fleck JH. The Theory of Electric and Magnetic Susceptibilities. Oxford, 1932.

46. Adamo C, Barone V, Bencini A, Broer R, Filatov M, Harrison NM, Illas F, Malrieu JP, Moreira I.de PR. Comment on "About the calculation of exchange coupling constants using densityfunctional theory: The role of the self-interaction error". [J. Chem. Phys., 2005, 123:164110]. Journ. Chem. Phys., 2006, 124:107101.

47. Noodleman L. Valence bond description of antiferromagnetic coupling in transition metal dimmers. J. Chem. Phys., 1981, 74:5737-5742. 
48. Kahn O. Molecular Magnetism. VCH, New York, 1993.

49. Zayets VA. CLUSTER-Z1: Quantum-Chemical Software for Calculations in the s,p-Basis. Kiev, Institute of Surface Chemistry Nat Ac Sci of Ukraine, 1990.

50. Gao X, Zhou Z, Zhao Y, Nagase S, Zhang SB, Chen ZJ. Comparative study of carbon and BN nanographenes: Ground electronic states and energy gap engineering. Phys. Chem. A, 2008, 112:12677.

51. Enoki T, Kobayashi Y. Magnetic nanographite: an approach to molecular magnetism. J. Mat. Chem., 2005, 15:3999.

52. Sheka EF, Zayets VA, Ginzburg IYa. Nanostructural magnetism of polymeric fullerene crystals. J. Exp. Theor. Phys., 2006, 103:728-739.

53. Nai CT, Xu H, Tan SJR, Loh KP. Analyzing Dirac cone and phonon dispersion in highly oriented nanocrystalline graphene. ACS Nano, 2016, 10:1681-1689.

54. Liu Q, Liu C-X, Xu C, Qi X-L, Zhang S-C. Magnetic impurities on the surface of a topological insulator. Phys. Rev. Lett., 2009, 102:156603.

55. Checkelsky JG, Ye J, Onose Y, Iwasa Y, Tokura Y. Dirac-fermion-mediated ferromagnetism in a topological insulator. Nature Phys., 2012, 8:729-733.

56. Dreiser J, Pacchioni GE, Donati F, Gragnaniello L, Cavallin A, Pedersen KS, Bendix J, Delley B, Pivetta M, Rusponi S, Brune H. Out-of-plane alignment of $\mathrm{Er}$ (trensal) easy magnetization axes using graphene. ACS Nano, 2016, 10:2887-2892.

57. Katmis F, Lauter V, Nogueira FS, Assaf BA, Jamer ME, Wei P, Satpati B, Freeland JW, Eremin I, Heiman D, Jarillo-Herrero P, Moodera JS. A high-temperature ferromagnetic topological insulating phase by proximity coupling. Nature, 2016, 533:513-516.

58. Sheka EF. Chemical susceptibility of fullerenes in view of Hartree-Fock approach. Int. J. Quant. Chem., 2007, 107:2803-2816.

59. Sheka EF. Chemical portrait of fullerenes. J. Struct. Chem., 2006, 47:593-599.

60. van der Lit J, Boneschanscher MP, Vanmaekelbergh D, Ijäs M, Uppstu A, Ervasti M, Harju A, Liljeroth P, Swart I. Suppression of electron-vibron coupling in graphene nanoribbons contacted via a single atom. Nat. Commn., 2013, 4:2023.

61. Warner JH, Lin Y-C, He K, Koshino M, Suenaga K. Atomic level spatial variations of energy states along graphene edges. Nano Lett., 2014, 14:6155-6159.

62. Nakada K, Fujita M. Edge state in graphene ribbons: Nanometer size effect and edge shape dependence. Phys. Rev. B, 1996, 54:17954-17961.

63. Barnard AS, Snook IK. Modelling the role of size, edge structure and terminations on the electronic properties of graphene nano-flakes. Modelling Simul. Mater. Sci. Eng., 2011, 19:054001.

64. Acik M, Chabal YJ. Nature of graphene edges: A review. Jpn. J. Appl. Phys., 2011, 50:070101.

65. Mishra PC, Yadav A. Polycyclic aromatic hydrocarbons as finite size models of graphene and graphene nanoribbons: Enhanced electron density edge effect. Chem. Phys., 2012, 402:56-68.

66. Ang LS, Sulaiman S, Mohamed-Ibrahim MI. Effects of size on the structure and the electronic properties of graphene nanoribbons. Monatsh. Chem., 2013, 144:1271-1280.

67. Hoffmann R. Small but strong lessons from chemistry for nanoscience. Ang. Chem. Int. Ed., 2013, 52:93-103.

68. Mayer I. On bond orders and valences in the ab initio quantum chemical theory. Int. J. Quant. Chem., 1986, 29:73-84.

69. Sheka EF, Popova NA. Odd-electron molecular theory of the graphene hydrogenation. J. Mol. Model., 2012, 18:3751-3768.

70. Sheka E, Popova N. Molecular theory of graphene oxide. Phys. Chem. Chem. Phys., 2013, 15:13304-13332.

71. Lu G, Yu K, Wen Z, Chen J. Semiconducting graphene: converting graphene from semimetal to semiconductor. Nanoscale, 2013, 5:1353-1367.

72. Chernozatonski LA, Sorokin PB, Belova EE, Brüning J. Superlattices consisting of 'lines' of adsorbed hydrogen atom pairs on graphene, JEPT Lett., 2007, 85:77-81.

73. Lu N, Huang Y, Li H-b, Li Z, Yang J. First principles nuclear magnetic resonance signatures of graphene oxide. J. Chem. Phys., 2010, 133:034502. 
74. Pan S, Aksay IA. Factors controlling the size of graphene oxide sheets produced via the graphite oxide route. ACS Nano, 2011, 5:4073-4083.

75. Nebogatikova NA, Antonova IV, Prinz VYa, Kurkina II, Vdovin VI, Aleksandrov GN, Timofeev VB, Smagulova SA, Zakirova ER, Kesler VG. Fluorinated graphene dielectric films obtained from functionalized graphene suspension: preparation and properties. Phys. Chem. Chem. Phys., 2015, 17:13257-13266.

76. Wang X, Bai H, Shi G. Size fractionation of graphene oxide sheets by $\mathrm{pH}$-assisted selective sedimentation. J. Am. Chem. Soc., 2011, 133:6338-6342.

77. Kang JH, Kim T, Choi J, Park J, Kim YS, Chang MS, Jung H, Park K, Yang SJ, Park CR. The hidden second oxidation step of Hummers method. Chem. Mat., 2016, 28:756-764.
78. Elias DC, Nair RR, Mohiuddin TMG, Morozov SV, Blake P, Halsall MP, Ferrari AC, Boukhvalov DW, Katsnelson MI, Geim AK, Novoselov KS. Control of graphene's properties by reversible hydrogenation: evidence of graphane. Science, 2009, 323:610-613.

79. Balog R, Jorgensen B, Nilsson L, Andersen M, Rienks E, Bianchi M, Fanetti M, Lægsgaard E, Baraldi A, Lizzit S, Sljivancanin Z, Besenbacher F, Hammer B, Pedersen TG, Hofmann P, Hornekær L. Bandgap opening in graphene induced by patterned hydrogen adsorption. Nature Mat., 2010, 9:315-319.

\section{ГРАФЕН - АИРАКОВСКИЙ МАТЕРИАА}

\section{Шека Е.Ф.}

Российский университет Аружбы народов, http:/ /www.rudn.ru

117198 Москва, Российская Федерация

Поступила в редакиию 04.10.2016

Представлена действительнылм иленом РАЕН С.П. Губиныцм

В статье представлен взгляд автора на глубокие спиновые свойства графена, подАерживаемые многочисленными экспериментальными и расчетными доказательствами. Аираковские фермионы кристамлического графена и мокальные спины графеновых молекул предмагается подчинить строгому требованию "разАичные орбитали ААя разАичных спинов", что приводит к большому спектру эффектов, обусловленных спиновой поляризацией эмектронных состояний. Как слеАствие - топологическая нетривиальность, Аелающая графен топологическим изолятором, и мокальные спины, обеспечивающие химическую активность графена, позволяют обсудить такие специфические свойства графена, как высокотемпературный ферромагнетизм и незаурядное химическое поведение. ОбсужАается связь этих новых результатов с трудностями попытки преобразовать полуметамический графен в полупроводник.

Ключевъге слова: графен, фермионы Аирака, квази-ремятивистское описание, гексагонамьная сотовая структура, мокальные спины, молекулы открытой оболочки, спин-орбитальное взаимодействие, спиновый изомятор, высокотемпературный ферромагнетизм, химическая реактивность

PACS: 51.05.ue 


\section{АВУХСАОЙНЫЙ ГРАФЕН КАК МЕМБРАНОМИМЕТИК: МОАЕАИРОВАНИЕ ИОННЫХ КАНААОВ}

${ }^{1}$ Градов О.В., ${ }^{1,2}$ Градова М.А.

${ }^{1}$ Институт энергетических проблем химической физики им. В.А. Тальрозе РАН, http:/ /www.inepcp.ru 117829 Москва, Российская Федерация

${ }^{2}$ Институт химической физики им. Н.Н. Семенова РАН, http:/ /www.chph.ras.ru

119991 Москва, Российская Федерация

Поступила в редакиило 14.11.2016

Представлена действительнымм иленом Р АЕН С.П. Губиньмм

Перспективы использования графена мембраномиметических материалов, Ао определенных пределов имитирующих функции биологических мембран, анализируются в преАставленном цикле работ. В настоящей работе рассматривается возможность моделирования функций ионных каналов на базе графена и ряда его производных. ОбсужАаются физические механизмы избирательной проницаемости Аля различных мембраномиметиков, а также границы адекватного моделирования транспортных, каталитических, сенсорных и эмектрогенных свойств ионных каналов на основе Авухслойных графеновых структур.

Ключевъге слова: ионные каналы, графен, миметики каналов, нанопоры, капимяярная химия, EDLC, ионоселективные и химические полевые транзисторы

PACS: 81.05.ue

\section{СодЕРЖАНИЕ}

1. ВВЕАЕНИЕ (154)

2. ПОАУПРОНИЦАЕМОСТЬ И ИОННЫЕ КАНААЫ (154)

3. НААИЧИЕ ПОР И ИОННЫХ КАНААОВ В ГРАФЕНОВЫХ НАНОСТРУКУРАХ (158)

4. ЗАКАЮЧЕНИЕ (161)

АИтература (161)

\section{1. ВВЕАЕНИЕ}

В работе [1] представлен обзор мембранных моделей - полусинтетических, синтетических, биогенных, полупроводниковых, сверхпроводящих, ферроэлектрических - и соответствующих мембраномиметиков от фосфолипидных бислоев и менгмюровских пленок АО многослойных нанопленок и ферромагнитных структур, наряду с рассмотрением проблем неоднозначности моделей, полноты мембраномиметического моделирования, функциональной и суб̆стратной эквивалентности мембраномиметиков. Применение аналогичных функциональных критериев подобия Аля анализа возможности рассмотрения графена, в частности, Авуслойного графена как мембраномиметика - предмет настоящей работы, с акцентом на анализ ключевого его свойства
- свойства проницаемости Аля ионов, воАЫ и иной органики.

\section{2. ПОАУПРОНИЦАЕМОСТЬ И}

\section{ИОННЫЕ КАНААЫ}

Общеизвестным явАяется наличие гибко регулируемой полупроницаемости по отношению к разАичным агентам графеноксидных мембран в органических растворителях, причем размер наноканалов, обеспечивающих пропускание/блокирование отдельных агентов, может быть сужен путем термического отжига, Аибо расширен за счет сольватации, изменяя тем самым границу размерной селективности пропускания носителей [2]. Это соответствует известным моделям “size/solubility"-регуляции натриевых ионныхканалов [3]иадекватнымаппроксимациям кинетики, зависящей от радиуса иона [4]. Являясь частным случаем применимости принципа количественных отношений структуры и биологической активности (QSAR) [5], принципы анализа регулируемости функции ионных каналов по параметрам стоков, которыми явАяются соответствующие мембранные поры, и размерам тех частиц, 
которые проникают сквозь эти поры, в случае графеновых пленок дают сбой, так как объект анализа выполняет «биологическую» функцию при том, что химическая структура его вовсе не является биоорганической и, более того, не входит и не может входить в базы данных ионных каналов [6], которые могли бы быть использованы Аля получения Аанных QSAR.

Следует напомнить, что ранее анацогичные сбои подходы QSAR Аавали при анализе поведения мипидных нанопор, работавших как ионные каналы клеточных мембран, не содержащие классических элементов каналов [7], в силу размерных характеристик, адекватных размерам соответствующих ионов (обычно Ааже в случае признания зависимости входа той или иной группы каналов от размера ионов используются сложные биохимические и кристалмографические модели вПлоть АО гомогексамерной [8], то есть - совместимые с принципами QSAR на базе анализа конформации или стерической доступности биомакромолекул канацома).

В связи с Аанным противоречием было бы целесообразно указать на известные Аанные по ионной проницаемости синтетических фильтров, не анализировавшиеся методами QSAR в силу эквивацентных причин: было показано, что ионы, проходящие через синтетические фильтры из полиэтилентерефталата) механизмами, мембраномиметическую отбираются обеспечивающими (биомиметическую) кинетику, Аемонстрирующую, эквивалентно клеточным ионным каналам, Аискретные быстрые переходы уровней проводимости, параметрическую селективность ионных потоков, атакже ингибирование Авухвалентными катионами $[9,10]$.

Всвязисэтимцелесообразносформулировать критерий верификации биомиметического характера мембраномиметических моделей, в основе которого Аежало бы не стандартное Аля классической детерминистской модели генерации электрофизиологического потенциала утверждение о Аискретном переходе состояний возбудимости («все или ничего» - «all-or-none law» [11, 12]), а утверждение оградациях эффективностиионных каналов по проводимости и генерируемому биоэлектрическому откиику.

Это Аогично, так как показано, что состояния ионных канацов (яв^яющихся прототипами Аанных мембраномиметических, а по существу - «каналомиметических» (channel mimetics) [1315] моделей) с низкой ионной проводимостью не являются «закрытыми», а меняются с определенными градациями, обеспечивающими различимые и качественно («ионоселективно»), и количественно (по проницаемости) типы мембранно-электрофизического или электрофизиологического отклика, являясь причиной специфических шумов каналома на патч-кламп-регистрограммах [16] (мембранные шумы графена, являющиеся критерием электрофизической мембраномиметики, будут рассмотрены ниже). Это не говорит о подобии структур и возможности реАукции молекулярной машинерии каналома до уровня обычных пор (ни в коем случае), однако говорит об общих принципах работы малоспецифических физических механизмов на наномасштабах, на которых размерные эффекты обусловливаются физикой, а не химией, т.е. инвариантны к химизму среды и к макромолекулярной морфологии (био)полимеров (в стандартном смысле этого термина, придававшемся ему П.Аж. ФАори (P.J. Flory) [17, 18], Нобелевским мауреатом, которому, в частности, принадлежит авторство уравнения ФАори-Хаггинса, которое, в формальном аспекте, явцяется анацогом уравнения Ван-дер-Ваальса и, как следствие этого, может быть применено на тех масштабах и при той физике явлений, которую мы обзорно рассматриваем в данной работе).

По вышеприведенным причинам, биомиметическая интерпретация и присваивание специфических свойств биологических мембран графену и Аругим (адекватным к размерам ионов) пленочным мембраномиметикам, хотя и не противоречит фактам, явцяется цогической ошибкой инверсии, смешением АеАуктивного и индуктивного предиката: графен и мембрана кАетки, имеющие поры идентичного размера, благоприятствующие входу в клетку или поА пленку ионов с определенными параметрами, очевидно, подчиняются еАиным физикохимическим принципам (что проявАяется, 
в частности, в подобии сольватационной регуляции и электрофизического отклика), следовательно, «в Аанном аспекте графен мембраномиметик в той же мере, как и мембрана (в том же аспекте) - графеномиметик».

Это говорит о том, что задача подобия (в том числе - указанного выше QSAR) Аля структур Аанного рода, если решать её сквозь призму молекулярной биологии, а не биофизической (и биоколцоиАной) химии, некорректна. По принципам классической

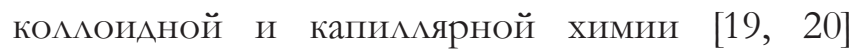
можно определить границы эффективности сорбционных процессов в каналах и порах той или иной величины, что применимо и ААя цитофизиологии [21] (изотерма аАсорбции ФрейнАлиха [22], как известно, носит имя Герберта ФрейнАлиха - основателя капимлярной химии и инициатора капимлярно-химического направления в физиологии). Таким образом, рациональнее ставить проблему каналомики графен-оксидных мембраномиметиков как вопрос о размерных эффектах, присущих первым в аспекте аАсорбции и абсорбции, фильтрации и размерной сепарации частиц, но не как вопрос о специализированных структурах,

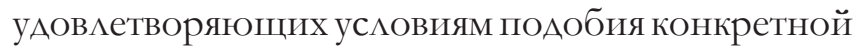
цитофизиологической форме прояв $е$ ения физико-химических механизмов сепарации («подобия общего частному его проявлению»).

Эффекты зависящего от размера частиц пропускания агентов сквозь пленки графена хорошо известны в нанохимии [23, 24]. Реактивность по отношению к газам [25] и электрохимические свойства наноэлектродных слоев графена [26] также зависят от размера пор. Это направление - т.н. "size-dependent electrochemistry" концептуально явцяется продолжением "kapillarchemie" ФрейнАлиха. Аанный подход широко применим не только в химии углеродных структур, но и в наноструктурном материацовеАении в целом.

Если говорить об углеродных структурах, родственных графену, то наноэлектрохимия, основанная на размерных эффектах, применялась в исследованиях многослойных слоистых углеродных нанотрубок [27], а также

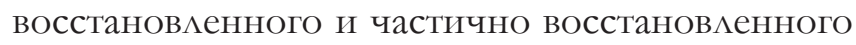
оксила графита [28], являющегося электродным материалом при создании Авухслойных конденсаторов [29], часто рассматриваемых в модальностях миметиков и моделей бислойных биомембран [30-34], также как и слоистые суперконденсаторы EDLC-типа ("electric double-layer capacitor”), имеющие выраженные зависимости между размерами ионов и пор [35], аналогично биологическим мембранам и мембранным биомиметикам, рассмотрение которых было проведено выше. К слову сказать, восстановленный оксил графита используется в подобных суперконденсаторах как электродный материал [36], что позволяет воспроизводить на EDLC-моделях мембран на его основе не только функции запасания энергии, но и биохимические рецепторные функции типа детектирования специфических медиаторов/нейротрансмиттеров/нейрогормонов (например - Аофамина [37-39]), выполняя его на электрохимических принципах без опосредования этого процесса специфическими высокомолекулярными агентами [40-42] (в частности - в силу толщинно-зависимых гилрофобных свойств графена, формально подобных размерно-зависимым свойствам «трансграфенного переноса» различно заряженных биомолекулярных агентов через поры в его гидрофобной поверхности [43, 44], что ставит проблему инжиниринга рецептирующих графеновых биомиметиков в разрял решаемых физикой, эквивалентной методам Аизайна миметиков рецепторов (receptor mimetic peptides) [45] на базе моделирования гилрофобных взаимодействий).

$\mathrm{Ha}$ Аанный момент все искАючения из Аанного реАукционистского правила, в сущности, только подтвержАают правило, так как диапазон зарядов, масс и других физикохимических характеристик используемых в композитных техниках веществ, равно как и их биохимические (ими иммунохимические в случаях, когда можно так охарактеризовать принципы Аетектирования) аффинности различаются на порялки: аптамеры/нуклеиновые кислоты [46-47]; проводящие полимеры, такие, как полипиррол (и на графене, и на пиролитическом графите) [48-51]; порфирины и их производные, качественно отАичающиеся по физико-химическим свойствам и аспектам 
поведения в растворах [52-53]; аминосахара производные минейных полисахаридов - такие, как хитозан $[55,56]$, использующийся в качестве среды Аля иммобилизации; полимерные электролитические мембраны, в частности, на основе фторсодержащих сополимеров - фторуглеродных виниловых эфиров, вкАючающих сульфогруппы (общеизвестный пример - нафион), в том чис $е$ - с композитной импрегнацией неорганическими частицами и структурно-модифицирующими агентами [57-59]; собственно, сами неорганические частицы и кластеры - наночастицы золота, меди, никеля и оксида цинка [61-68]; Аопирующие графен элементы, в частности - азот [69, 70]. Хотя это неполный список, но на нем Аостаточно полно представлены границы различных массовых и зарядовых характеристик Аля молекул, встречающихся в рецептирующих мембраномиметических структурах на базе графена и его производных. Хотя в некоторых случаях электрофизический отклик и не регистрировался напрямую (только по вторичным индикаторам - типа редоксзависимой фмуоресценции), приведенной информации может быть Аостаточно Аля заключения «От противного» о корректности модели редукционистского типа, не вкАючающей потребность в биоорганических или высокомолекулярных агентах Аля реализации рецепторных функций Аанными мембраномиметиками.

Надо сказать, что графеновые наноструктуры часто предназначаются одновременно ААя создания n-слойных суперконденсаторов и сенсоров к различным агентам, срабатывающих без участия ферментов [71]. В этих сенсорах

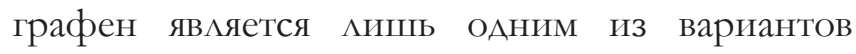
суперконденсатора-существуютбиосенсоры [72], сенсоры газов [73] и вцажности [74] (эти сенсоры могут одновременно запасать электроэнергию) на базе мембран суперконденсаторных покрытий отличного от графена состава. При этом, с точки зрения канацомики Аанных мембраномиметиков, надо отметить, что сенсорные мембраны суперконденсаторов могут сепарировать ионы, синтетические и биогенные молекулы (см. напр., [75]) и участвовать в Аиссоциации солей, вырабатывая при этом энергию [76] на принципах создания ионного градиента (эквивалентно хемиосмотической модели Митчелма, цитировавшейся ранее). То есть, сенсорные и энергообеспечивающие свойства мембраномиметиков на базе графена и подобных структур, в частности, используемых в суперконденсаторах и датчиках параметров сред, буаучи подобными по феноменологии ряау фунааментальных отАичительных свойств биомембран, обеспечиваются электрофизическими механизмами (полярность) неполярность молекул; их гиАрофильность/ гилрофобность Аибо миофильность/ миофобность; ряА свойств, имеющих отношение к координации по нескомпенсированному зарялу). Нет смысла останавливаться на биосенсорных характеристиках графеновых мембраномиметиков в Аанном разделе, так как они будут рассматриваться отАельно, равно как и хемосенсорные, но рассмотрение сенсорных свойств мембраномиметиков на основе суперконденсаторов было здесь рационально в контексте экстраполяции критериев канало-/ мембраномиметического моделирования и «сведения к единому знаменателю» сенсорных, сепаративных и электрофизических характеристик моделирующей физической системы.

В связи с означенными корреляциями электрических и транспортных (ионоселективных, химических и Ар.) свойств необходимо указать на тип их взаимодействия, при которых такое взаимодействие кооперативно. На Аанный момент хорошо теоретически изучены ISFET (ионоселективные полевые транзисторы) на основе графена, чувствительные к Аинамике $p H$ (редокспотенциала), то есть - концентрации протонов [77], что явно коррелирует с хемиосмотической моделью мембранного электрогенеза Митчелца и, одновременно, с моделями биомембраны как транзисторной структуры, распространенными с 1960-х гг. [78]. Перенос ионов, сенсинг и изменение электрических параметров сенсора в них синхронизированы и взаимообусловлены. Надо сказать, что Аля ионоселективных полевых транзисторов (ISFET), равно как и Аля химическиселективных полевых транзисторов вообще (ChemFET, частным режимом или случаем 
работы которых является ионоселективное распознавание [79, 80], т.е. ISFET), в принципе не существует отличия межАу «мембранной селективностью» и «специфичностью электрооткиика сенсора» [81]. В последнее время в качестве ионных сенсоров Аля микрофлюидных и нанофлюилных систем хемометрического назначения (Аабораторий на чипе) используют ионные транзисторы, принципы работы которых основаны на ионно-градиентной поляризации ионообменных мембран [82], способных выполнять задачи электрогенного ионообмена и сенсинга, характеризующегося откАиком в электрической модальности, одновременно. Аналогичные возможности, в принципе, имеются у графеновых или графен-оксилных ионообменников, а также композитных ионообменных материалов на их основе [8385], в силу чего принципы синхронизации различных аспектов их активности как мультифункциональных мембраномиметиков реализуемы и в случае графена и его аналогов/ продуктов/производных, применимых как FET. Следует отметить, что Аля выполнения большинства подобных функций графенсодержащие конструкции Аолжны обладать свойствами FET, а не целостного ChemFET: хорошо известны сенсоры на основе графеновых и графен-содержащих FЕТ-структур, не позиционирующихся напрямую в роли ChemFET, но используемых Аля редокс-сенсинга [86], аптасенсинга [87], электрохимического биосенсинга [88], сенсинга ионов метациов [89], а также как компоненты биоэлектрохимического биоэлектронного «носа» [90]. Это связано с качественной зависимостью отклика графеновых FEТотокружающейжиАкостнойилипарофазной среды [91], сопряженной, в частности, с увеличением подвижности носителей заряда (Аырок), уменьшением остаточной концентрации носителей и изменениями в трафике молекул, индуцированными заряженными дефектами (т.н. «перфорацией») вблизи поверхностей активных слоев. В свою очередь, перечисленные эффекты можно связать с зарядовым транспортом, а также ориентацией молекул, индуцируемой зарядом вблизи поверхности FET [92], однако это требует наличия вакантных пор и зарядовых дефектов в мембраномиметической поверхности (аналогичных структурно-электрофизическим особенностям биомембран, в которых электрогенные особенности, ионный транспорт и пространственная ориентация молекул в управ яющем им электрическом по е сопряжены и взаимно-однозначно колокализованы [93]).

\section{3. НААИЧИЕ ПОР И ИОННЫХ КАНААОВ В ГРАФЕНОВЫХ НАНОСТРУКУРАХ}

Рассмотрим вопрос о наличии пор и аналогов ионных каналов (Аибо возможности их реализации) в графене и продуктах его переработки или прекурсорах и родственных им соединениях. Известны газотранспортные [94] и ионно-транспортные [95] каналы в маминарном оксиде графена и в графеновых наноструктурах электрофизического (электротехнического -

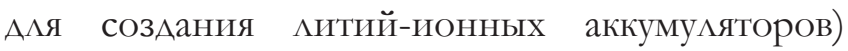
назначения. Все феномены селективного ионопроникновения сквозь графеновые структуры имеют в основе работу Аанных каналов. В митературе можно найти аналоги всех основных ионных канацов, реализованные на базе графеновых нанопор/каналов [96, 97]: Аля щелочных металцов [98], включая биомиметические (биоинспирированные) анацоги натриевых и калиевых каналов [99] (иные щелочные металАы - митий, рубидий и цезий, как показывает практика [100-102] и следует из термодинамических расчетов Аця одновацентных катионов [103] и квантово-химических моделей Аля ряда ионов щелочных метац ов [104], также способны работать в каналоме, но их кларк весьма низок и не позволяет выполнять какиемибоо функции в макромасштабах на уровне организма и биосферы), Аля ионов хлора [105] (аналоги известных хлорных канацов [106, 107]) и т.А. Мы здесь специально не рассматриваем имеющие прецеденты в графеновой отрасли, но не релевантные, хотя и существующие в ролях биологических агентов, каналы и поры (такие как срабатывающие на рубилий, галолиний и Ар. редкоземельные металлы, мантаноиды, актиноиды [108, 109]), чтобы не отходить от биомиметической функционацьной анацогии.

При синтезе биомиметических ISFET на базе графена важен аспект «совместимости с каналомом», так как ISFET на базе 
углеродных наноструктур используются Аля электрофизических исследований в нейроцитологии [110], т.е. образуют контакты с нейроном, которые явцяются ионообменными структурами межАу канацомом и FET, реагирующими на внеклеточную среду и опосредованную ей стимуляцию или ингибирование ионно-транспортной активности каналов [111].

$\begin{array}{ccr}\text { Факты, накопившиеся } & \text { за последнее } \\ \text { время } & \text { относительно } & \text { возможности }\end{array}$
имитации работы ионных канацов, а также возможности их встраивания в графеновые капсулы или мембраноподобные структуры, к 2015 г. Аали возможность перехода к рассмотрению графеновых капсул с ионоселективными каналами как протоклеток или же «эмбриональных» (т.е. не развитых Ао зрелого Аефинитивного состояния воспроизведения полной функциональности живой клетки) модельных протоклеток [12, 113]. Эта интерпретация может вызывать вопросы, однако, учитывая, что ранние модели протоклеток представляли собой мембранные фосфолипидные структуры [114-116], мембраномиметический смысл Аанной абстракции не вызывает сомнений (хотя и не является прорывом на фоне множества безлипидных [117], безмембранных [118] и переключаемых Авойным слоем/ электростатически в отсутствие мембраны [119], неорганических [120, 121] и минеральных [122, 123] протоклеток), то есть налицо замещение мембраны её функциональной альтернативой.

ОАнако очевилно, что альтернатива действует не так, как оригинац, хотя и обеспечивает химический сенсинг в окрестности графеновых поверхностей [124]: проведение частиц сквозь графеновые пленки может производиться не только по критерию массы или заряда [125], но и по критерию спина [126], что в корне отличается от общепринятой физики биомембранпрототипов (хотя спиновые методы и спиновые метки нередко используются в биофизике и цитофизиологии, при исследовании свойств ионных каналов и мембранной проницаемости [127-131]). Таким образом, речь илёт о проведении физических агентов, а не химических (ионных) носителей QSPR/QSAR-сопряженных характеристик и химико-физиологических свойств. В таком случае модель может считаться объективной только если онаадекватна оригиналу эмерджентно, по механизмам формирования; функционально отличающиеся качественно модели порожлаются разными принципами, и в силу этого не воспроизводят свойства оригинала ровно в той мере, что задается разАичием их механизмов формирования или, точнее, именно отличием их механизма формирования от формирования оригинала Аля случая, если он формировался бы на той же вещественной (субстратной - в биологической терминологии) базе.

Известны работы по формированию графеновых каналов методами индуцированного скручивания графеновых поверхностей в трубку [132]. В биологии это имеет анацогию в виде сборки модельных каналов на базе самоорганизующихся

(фолАингом) пептидных нанотрубок [133], формирующихся непосредственно в процессе взаимодействия их с лигандом [134] (как наАмолекулярный [135] отклик на это взаимодействие). Анацогичным путем самоорганизуются модельные сети ионных каналов на базе жилкокристаллических биконтинуальных кубических фаз [136] или колончатых фаз на базе краун-эфиров в билипидных слоях [137] (немного иначе происходит сборка ионных каналов на базе Аенаримеров ввиду их разветвленной структуры [138], но этот специальный случай не является характеристичным и не может быть воспроизведен на базе планарных графеновых мембраномиметических носителей, поэтому детально не рассматривается). Иной механизм самосборки мембраны и, слеловательно, мембранных каналов характерен Аля условий темплатирования, моделью которого является формирование графеновых поверхностей на каталитическиактивных и ультрамикроструктурированных подложках (например - Аля получения FET и ионосе лективных структур [139, 140]).

Каталитическая

структуризация подповерхностного слоя [141] яв $\Lambda$ яется неизбежным условием синтеза на поверхности каталитически активированных структур. 
Темплатирование каталитических

на неорганических необходимым поверхностях

яв $А$ ясся неорганических $\triangle \wedge я$

синтеза

множества

каталитически-активных (до определенных пределов самосборки автокатацитически)

редокс-поверхностей [142]; анацогичные требования работают в синтезе слоев с каналами, опосредованном метац ическими темплатирующими поверхностями [143]. В таких синтезах вакансии, срабатывающие затем в роли затравок формирования каналов, также участвуют в определении и направлении форм структуризации поверхности при фазовых переходах [144]. Аналогичную, но качественно обратную роль имеют ионы металлов: темплатирование молекулами поверхностноактивных веществ на солевых поверхностях с металмическими аАлуктами формирует метац отропные жиАкокристациические фазы [145]. Учитывая применимость методов каталитического темплатирования Аля синтеза оксил-графеновых наноструктур [146], возможно создание на их основе биомиметических/ мембраномиметических поверхностей, роль миметиков каналов в которых будут выполнять структуры, формируемые по темплатным и смежным с ними механизмам. Это будет адекватно как темплатно-ассоциированному синтезу пептидных систем, формирующих ионные каналы [147], так и формированию синтетических неорганических трансмембранных трубок и каналов при мипидном темплатировании [148], то есть будет субстратно независимым как от класса биомолекулярных и супрамолекулярных носителей, так и от органического/неорганического химизма носителя функциональных свойств каналов или их прекурсоров вообще, что и требуется А^я агентного моделирования их миметиков.

Рассматривая более глубоко проблему катализа в самоорганизации миметиков ионных каналов, в том числе - графеновых миметиков, надо указать на каталитическую функцию канацов-прототипов. Каталитически активны как катионные (например - кальциевые [149], характеризующиеся сопряжением каталитических и канальных функций при АТФ-опосредованном транспорте $\left.\mathrm{Ca}^{2+}\right)$, так и анионные [150] каналы и ионные насосы клеточной мембраны. У многих специфических регуляторов ионного переноса/ионной проводимости (таких, в частности, как CFTR cystic fibrosis transmembrane conductance regulator [151, 152]) функции катализа и регуляции открытия/закрытия каналов сопряжены. АТФчувствительные калиевые каналы (иногда записывающиеся как KATP/KATP или, в зависимости от места мокализации, sarcKATP Аля сарколеммы, mitoKATP Аля хондриома и nucKАТР Аля ядерной мокализации) также обладают каталитической функцией [153, 154]. Аналогично обстоит дело и с редоксрегуляторами и медиаторами метаболизма железа - ионными каналами на базе ферритина [155], а также их синтетическими производными мибо аналогами, формируемыми с включением наноструктур [156].

В принципе, речь иАёт о том, что синтетические каталитические поры [157] способны, в случае адекватности биологическим прототипампо ионной се ективности, выполнять функции ионных каналов с аналогичной (био) каталитической функцией. Возможность реализации этого в контексте агентных моделей определяется тем, что, во-первых, и Аля калиевых [158], и А^я натриевых [159] канацов (как наиболее известных и противоположных по значению - в состоянии покоя открыты калиевые каналы и закрыты натриевые, так как параметрика потенциала покоя близка к равновесному потенциалу Нернста Аля ионов калия) в разАичном аспекте существенен катализ; во-вторых, как было указано выше, это работает и

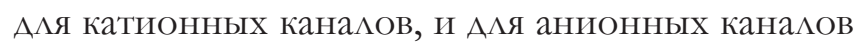
(название хлоридных каналов в данном случае не в полной мере отвечает действительности, так как они же проводят ионы $\mathrm{HCO}_{3}{ }^{-}, \mathrm{I}^{-}, \mathrm{SCN}^{-}$и $\mathrm{NO}_{3}{ }^{-}$), а в-третьих, взаимозаместимостью одновалентных катионов во многих модельных ионоселективных системах [160]. С Аругой стороны, каталитические функции и распознавание мигандов возможны и в отсутствие ионных канацов - путем пикатионных взаимодействий [161]; в то же время, сопряжение фаз генерации потенциала и ката^иза в мембране может осуществцяться АипиАным путем, например, фосфолипидом типа $\mathrm{PI}(4,5)$ P2 (phosphatidylinositol 4,5-bisphosphate, 
фосфатилилинозитол

4,5-бисфосфат)

[162] (комментарий к [163]). Таким образом, характер агента и его структура не явАяются существенными Аля имитации его функции, но адекватность функции является критерием подобия модели оригиналу.

В качестве характеристичного примера в каталитическом аспекте следует привести водные каналы, функция которых ассоциируется с активными в каталитическом аспекте сайтами [164]: их воспроизведение в графеновой пленке или графитовой поверхности в форме водопроницаемых каналов $[165$, 166] может быть реализовано (при наличии Авижущего градиента) вне рамок структурного моделирования и синтеза/Аизайна миметиков каналов при использовании простой пассивной модели мембраны с проницаемостью, зависящей от размера ионов, и водопроницаемостью в тех же каналах или особенностях поверхности [167]. Это соответствует, в больше степени, модели мембранных пор и неселективных независимых ионных каналов, проницаемость которых определяется размерами ионов или молекул; однако естественные водные каналы - интегральные белки аквапорины - также, как виАно из названия, явАяются порами, которые, в зависимости от диаметра и формы, пропускают также глицерин, аммиак, мочевину и углекислый газ [168].

\section{4. ЗАКАЮЧЕНИЕ}

В общем случае, агентное функциональное воспроизведение ионных каналов на графеновых носителях не только возможно, но и сопряжимо с требованием колокализации ионоселективных и электрогенных функций, вытекающим из анализа функций биофизического прототипа - мембраны. Примером реализующей это структуры могут яв яться каналы в графене ISFET - ионоселективных полевых транзисторов [169, 170], рассмотренных выше. ОАнако, существуют Ава аспекта электрогенеза, которые не могут быть проигнорированы при анализе поведения каналов в графене ISFET. Речь идёт, во-первых, о Авойном электрическом слое, который явАяется абсолютным теоретическим пределом Аизайна наноэлектронных систем, а, во-вторых, о Авухслойности биологической мембраны как конденсатора (что требуется Аля моделирования её периодической разрядки в форме потенциалов Аействия и пробоя в зоне формирования мембранных пор), которой Аолжна быть сопоставлена Авухслойная структура графенового агентного мембраномиметика. Тогда «логическая производительность» и «скважность» работы графеновых каналов [171] в электрогенной среде - Авухслойном графене - будет иметь более высокую степень аналогии с биологическим прототипом. Прицельное рассмотрение Авойного слоя как Арайвера электрогенных процессов и мембраномиметической структуры, наряду с рассмотрением отличий Авухслойных и многослойных структур на основе графена от их однослойных аналогов в мембраномиметике, будет произведено в следующей части настоящего цикца статей.

\section{МИТЕРАТУРА}

1. Градов ОВ. Мембранные модели и анзац Авухслойного графена как мембраномиметика. Радиоэлектроника. Наносистемы. Информачионные технологиии (РЭНСИТ), 2016, 8(1):25-38; DOI: 10.17725/ rensit.2016.08.025.

2. Huang L, Li Y, Zhou Q, Yuan W, Shi G. Graphene Oxide Membranes with Tunable Semipermeability in Organic Solvents. $A d v$ Mater., 2015, 27(25):3797-3802.

3. Courtney KR. Sodium channel blockers: the size/ solubility hypothesis revisited. Mol. Pharmacol., 1990, 37(6):855-859.

4. Courtney KR. Size-dependent kinetics associated with drug block of sodium current. Biophys. J., 1984, 45(1):42-44.

5. Courtney KR. Quantitative structure/activity relations based on use-dependent block and repriming kinetics in myocardium. J. Mol. Cell Cardiol., 1987, 19(3):319-330.

6. Le Novère N, Changeux JP. The Ligand Gated Ion Channel database: an example of a sequence database in neuroscience. Philos. Trans. R. Soc. Lond. B: Biol Sci., 2001, 356(1412):1121-1130.

7. Pakhomov AG, Bowman AM, Ibey BL, Andre FM, Pakhomova ON, Schoenbach KH. Lipid nanopores can form a stable, ion channel-like conduction pathway in cell membrane. Biochem. Biophys. Res. Commun., 2009, 385(2):181-186. 
8. Cruickshank CC, Minchin RF, Le Dain AC, Martinac B. Estimation of the pore size of the large-conductance mechanosensitive ion channel of Escherichia coli. Biophys. J., 1997, 73(4):1925-1931.

9. Lev AA, Korchev YE, Rostovtseva TK, Bashford CL, Edmonds DT, Pasternak CA. Rapid switching of ion current in narrow pores: implications for biological ion channels. Proc. Biol. Sci., 1993, 252(1335):187-192.

10. Korchev YE, Bashford CL, Alder GM, Apel PY, Edmonds DT, Lev AA, Nandi K, Zima AV, Pasternak CA. A novel explanation for fluctuations of ion current through narrow pores. FASEB J., 1997, 11(7):600-608.

11. Osterhout WJ. Nature of the action current in nitella: V. Partial response and the all-or-none law. J. Gen. Physiol., 1943, 27(1):61-68.

12. Osterhout WJ. Apparent violations of the allor-none law in relation to potassium in the protoplasm. J. Gen. Physiol., 1954, 37(6):813-824.

13. Steinle ED, Mitchell DT, Wirtz M, Lee SB, Young VY, Martin CR. Ion channel mimetic micropore and nanotube membrane sensors. Anal. Chem., 2002, 74(10):2416-2422.

14. Guo W1, Tian Y, Jiang L. Asymmetric ion transport through ion-channel-mimetic solid-state nanopores. Acc. Chem. Res., 2013, 46(12):2834-2846.

15. Wirtz M, Martin CR. Nanotube Membrane Sensors: Resistive Sensing and Ion Channel Mimetics. Sens. Upd., 2002, 11(1):35-64.

16. Korchev YE, Bashford CL, Alder GM, Kasianowicz JJ, Pasternak CA. Low conductance states of a single ion channel are not 'closed'. J. Membr. Biol., 1995, 147(3):233-239.

17. Flory PJ. Molecular morphology in amorphous and glass polymers. Journ. Non-Crystal. Sol., 1980, 42(1-3):117.

18. Flory PJ, De Yeung Y. Molecular morphology in semicrystalline polymers. Nature, 1978, 272:226-229.

19. Freundlich H. Kapillarchemie; eine Darstellung der Chemie der kolloide und verwandter Gebiete, Band 1. Leipzig, Akademische Verlagsgesellschaft, 1930, $566 \mathrm{p}$.

20. Freundlich H. Colloid \& capillary chemistry. New York, E.P. Dutton \& Company, 1922, 883 p.
21. Freundlich H. Kapillarchemie und Physiologie. Dresden, Theodor Stienkopff, 1914, 48 p.

22. Freundlich H. Die Adsorption in Lösungen. $Z$. Phys. Chem., 1906, 57(A):385-470.

23. Plant SR, Cao L, Yin F, Wang ZW, Palmer RE. Size-dependent propagation of $\mathrm{Au}$ nanoclusters through few-layer graphene. Nanoscale, 2014, 6(3):1258-1263.

24. Jeon KJ, Lee Z. Size-dependent interaction of $\mathrm{Au}$ nanoparticles and graphene sheet. Chem. Commun., 2011, 47(12):3610-3612.

25. Si C, Zhou G. Size-dependent chemical reactivity of porous graphene for purification of exhaust gases. J. Chem. Phys., 2012, 137(18):184309-1 -184309-6.

26. Zhang B, Fan L, Zhong H, Liu Y, Chen S. Graphene nanoelectrodes: fabrication and sizedependent electrochemistry. J. Am. Chem. Soc., 2013, 135(27):10073-10080.

27. Cardoso RM, Montes RH, Lima AP, Dornellas RM, Nossol E, Richter EM, Munoz RA. Multiwalled carbon nanotubes: Size-dependent electrochemistry of phenolic compounds. Electrochim. Acta, 2015, 176:36-43.

28. Tran MH, Yang CS, Yang S, Kim IJ, Jeong HK. Size dependent electrochemical properties of reduced graphite oxide. Chem. Phys. Lett., 2014, 608:207-212.

29. Hantel MM, Kaspar T, Nesper R, Wokaun A, Kötz R. Partially reduced graphite oxide as an electrode material for electrochemical double-layer capacitors. Chemistry, 2012, 18(29):9125-9136.

30. Rao S, Lu S, Guo Z, Li Y, Chen D, Xiang Y. A light-powered bio-capacitor with nanochannel modulation. Adv. Mater., 2014, 26(33):5846-5850.

31. Lamport DT, Varnai P, Seal CE. Back to the future with the AGP-Ca ${ }^{2+}$ flux capacitor. Ann. Bot., 2014, 114(6):1069-1085.

32. Kim I, Warshel A. A Microscopic Capacitor Model of Voltage Coupling in Membrane Proteins: Gating Charge Fluctuations in Ci-VSD. J. Phys. Chem. B., 2016, 120(3):418-432.

33. Ray S, Kassan A, Busija AR, Rangamani P, Patel HH. The plasma membrane as a capacitor for energy and metabolism. Am. J. Physiol. Cell Physiol., 2016, 310(3):C181-C192.

34. Gimsa J, Wachner D. A unified resistor-capacitor model for impedance, dielectrophoresis, 
electrorotation, and induced transmembrane potential. Biophys. J., 1998, 75(2):1107-1116.

35. Largeot C, Portet C, Chmiola J, Taberna PL, Gogotsi Y, Simon P. Relation between the ion size and pore size for an electric doublelayer capacitor. J. Am. Chem. Soc., 2008, 130(9):2730-2731.

36. Lobato B, Vretenár V, Kotrusz P, Hulman M, Centeno TA. Reduced graphite oxide in supercapacitor electrodes. J. Coll. Interf. Sci., 2015, 446:203-207.

37. Kannan PK, Moshkalev SA, Rout CS. Highly sensitive and selective electrochemical dopamine sensing properties of multilayer graphenenanobelts. Nanotechn., 2016, 27(7):075504-1 - 075504-9.

38. Qian T, Yu C, Wu S, Shen J. Gold nanoparticles coated polystyrene/reduced graphite oxide microspheres with improved dispersibility and electrical conductivity for dopamine detection. Coll. Surf. B: Biointerfaces, 2013, 112:310-314.

39. Qian T, Wu S, Shen J. Facilely prepared polypyrrole-reduced graphite oxide coreshell microspheres with high dispersibility for electrochemical detection of dopamine. Chem. Commun., 2013, 49(41):4610-4612.

40. Feng X, Zhang Y, Zhou J, Li Y, Chen S, Zhang L, Ma Y, Wang L, Yan X. Three-dimensional nitrogen-doped graphene as an ultrasensitive electrochemical sensor for the detection of dopamine. Nanoscale, 2015, 7(6):2427-2432.

41. Bagherzadeh M, Heydari M. Electrochemical detection of dopamine based on preconcentration by graphene nanosheets. Analyst, 2013, 138(20):6044-6051.

42. Cheemalapati S, Palanisamy S, Mani V, Chen SM. Simultaneous electrochemical determination of dopamine and paracetamol on multiwalled carbon nanotubes/graphene oxide nanocompositemodified glassy carbon electrode. Talanta, 2013, 117:297-304.

43. Munz M, Giusca CE, Myers-Ward RL, Gaskill DK, Kazakova O. Thickness-Dependent Hydrophobicity of Epitaxial Graphene. ACS Nano., 2015, 9(8):8401-8411.

44. Schneider GF, Xu Q, Hage S, Luik S, Spoor JN, Malladi S, Zandbergen H, Dekker C. Tailoring the hydrophobicity of graphene for its use as nanopores for DNA translocation. Nat. Commun., 2013, 4:2619.

45. Martin-Moe SA, Lehr R, Cauley MD, Moe GR. Hydrophobic interactions and the design of receptor mimetic peptides. Pept. Res., 1995, $8(2): 70-76$.

46. Wang X, You Z, Sha H, Cheng Y, Zhu H, Sun W. Sensitive electrochemical detection of dopamine with a DNA/graphene bi-layer modified carbon ionic liquid electrode. Talanta, 2014, 128:373-378.

47. Liu S, Xing X, Yu J, Lian W, Li J, Cui M, Huang J. A novel label-free electrochemical aptasensor based on graphene-polyaniline composite film fordopamine determination. Biosens. Bioelectron., 2012, 36(1):186-191.

48. Qian T, Yu C, Wu S, Shen J. In situ polymerization of highly dispersed polypyrrole on reduced graphite oxide for dopaminedetection. Biosens. Bioelectron., 2013, 50:157-160.

49. Qian T, Wu S, Shen J.Facilely prepared polypyrrole-reduced graphite oxide coreshell microspheres with high dispersibility for electrochemical detection of dopamine. Chem. Commun., 2013, 49(41):4610-4612.

50. Si P, Chen H, Kannan P, Kim DH. Selective and sensitive determination of dopamine by composites of polypyrrole and graphenemodified electrodes. Analyst, 2011, 136(24):5134-5138.

51. Mao H, Liang J, Ji C, Zhang H, Pei Q, Zhang Y, Zhang Y, Hisaeda Y, Song XM. Poly(zwitterionic liquids) functionalized polypyrrole/graphene oxide nanosheets for electrochemically detecting dopamine at low concentration. Mater. Sci. Eng. C: Mater. Biol. Appl., 2016, 65:143-150.

52. Wu L, Feng L, Ren J, Qu X. Electrochemical detection of dopamine using porphyrinfunctionalized graphene. Biosens. Bioelectron., 2012, 34(1):57-62.

53. Sakthinathan S, Lee HF, Chen SM, Tamizhdurai P. Electrocatalytic oxidation of dopamine based on non-covalent functionalization of manganese tetraphenylporphyrin/reduced graphene oxide nanocomposite. J. Coll. Interf. Sci., 2016, 468:120-127.

54. Yan X, Gu Y,LiC, Tang L, Zheng B, Li Y, Zhang Z, Yang M. Synergetic catalysis based on the proline tailed metalloporphyrin with graphene sheet as efficient mimetic enzyme for ultrasensitive 
electrochemical detection of dopamine. Biosens. Bioelectron., 2016, 77:1032-1038.

55. Niu X, Yang W, Guo H, Ren J, Yang F, Gao J. A novel and simple strategy for simultaneous determination of dopamine, uric acid and ascorbic acid based on the stacked graphene platelet nanofibers/ionic liquids/chitosan modified electrode. Talanta, 2012, 99:984-988.

56. Weng X, Cao Q, Liang L, Chen J, You C, Ruan Y, Lin H, Wu L. Simultaneous determination of dopamine and uric acid using layer-by-layer graphene and chitosan assembled multilayer films. Talanta, 2013, 117:359-365.

57. Ku S, Palanisamy S, Chen SM. Highly selective dopamine electrochemical sensor based on electrochemically pretreated graphite and nafion composite modified screen printed carbon electrode. J. Coll. Interf. Sci., 2013, 411:182-186.

58. Zhang W, Zheng J, Shi J, Lin Z, Huang Q, Zhang H, Wei C, Chen J, Hu S, Hao A. Nafion covered core-shell structured $\mathrm{Fe}_{3} \mathrm{O}_{4} @$ graphene nanospheres modified electrode for highly selective detection of dopamine. Anal. Chim. Acta., 2015, 853:285-290.

59. Liu CY, Liu ZY, Peng R, Zhong ZC. Quasireversible Process of Dopamine on Copper-Nickel Hydroxide Composite/Nitrogen Doped Graphene/Nafion Modified GCE and Its Electrochemical Application. J. Anal. Meth. Chem., 2014, 2014:724538.

60. Ly SY, Park, Won D. Diagnosis of Dopamine in Brain Neuro Cell Using a Nafion-immobilized Carbon Electrode. Med. Chem., 2012, Sep 10. [Preprint].

61. Yang L, Huang N, Lu Q, Liu M, Li H, Zhang Y, Yao S. A quadruplet electrochemical platform for ultrasensitive and simultaneous detection of ascorbic acid,dopamine, uric acid and acetaminophen based on a ferrocene derivative functional $\mathrm{Au}$ NPs/carbon dots nanocomposite and graphene. Anal. Chim. Acta., 2016, 903:69-80.

62. Wang P, Xia M, Liang O, Sun K, Cipriano AF, Schroeder T, Liu H, Xie YH. Label-Free SERS Selective Detection of Dopamine and Serotonin Using Graphene-Au Nanopyramid Heterostructure. Anal. Chem., 2015, 87(20):10255-10261.

63. Li C, Zhao J, Yan X, Gu Y, Liu W, Tang L, Zheng B, Li Y, Chen R, Zhang Z. Tremella-like
graphene-Au composites used for amperometric determination of dopamine. Analyst, 2015, 140(6):1913-1920.

64. Yan Y, Liu Q, Wang K, Jiang L, Yang X, Qian J, Dong X, Qiu B. Enhanced peroxydisulfate electrochemiluminescence for dopamine biosensing based on Au nanoparticle decorated reduced graphene oxide. Analyst, 2013, 138(23):7101-7106.

65. Chen X, Zhang G, Shi L, Pan S, Liu W, Pan H. $\mathrm{Au} / \mathrm{ZnO}$ hybrid nanocatalysts impregnated in $\mathrm{N}$-doped graphene for simultaneous determination of ascorbic acid, acetaminophen and dopamine. Mater. Sci. Eng. C: Mater. Biol. Appl., 2016, 65:80-89.

66. He P, Wang W, Du L, Dong F, Deng Y, Zhang T. Zeolite A functionalized with copper nanoparticles and graphene oxide for simultaneous electrochemical determination of dopamine and ascorbic acid. Anal. Chim. Acta., 2012, 739:25-30.

67. Liu B, Ouyang X, Ding Y, Luo L, Xu D, Ning Y. Electrochemical preparation of nickel and copper oxides-decorated graphene composite for simultaneous determination of dopamine, acetaminophen and tryptophan. Talanta, 2016, 146:114-121.

68. Liu CY, Liu ZY, Peng R, Zhong ZC. Quasireversible Process of Dopamine on Copper-Nickel Hydroxide Composite/Nitrogen DopedGraphene/Nafion Modified GCE and Its Electrochemical Application. J. Anal. Meth. Chem., 2014, 2014:724538.

69. Sheng ZH, Zheng XQ, Xu JY, Bao WJ, Wang $\mathrm{FB}$, Xia XH. Electrochemical sensor based on nitrogen doped graphene: simultaneous determination of ascorbic acid, dopamine and uric acid. Biosens. Bioelectron., 2012, 34(1):125-131.

70. Thanh TD, Balamurugan J, Lee SH, Kim NH, Lee JH. Effective seed-assisted synthesis of gold nanoparticles anchored nitrogen-doped graphene for electrochemical detection of glucose and dopamine. Biosens. Bioelectron., 2016, 81:259-267.

71. Madhu R, Veeramani V, Chen SM, Manikandan A, Lo AY, Chueh YL. Honeycomb-like Porous Carbon-Cobalt Oxide Nanocomposite for HighPerformance Enzymeless Glucose Sensor and 
Supercapacitor Applications. ACS Appl. Mat. Interf., 2015, 7(29):15812-15820.

72. Mousty C, Leroux F. LDHs as electrode materials for electrochemical detection and energy storage: supercapacitor, battery and (bio)-sensor. Rec. Pat. Nanotech., 2012, 6(3):174-192.

73. Liu Y, Jiao Y, Zhang Z, Qu F, Umar A, Wu X. Hierarchical $\mathrm{SnO}_{2}$ nanostructures made of intermingled ultrathin nanosheets for environmental remediation, smart gas sensor, and supercapacitor applications. ACS Appl. Mat. Interf., 2014, 6(3):2174-2184.

74. Must I, Johanson U, Kaasik F, Põldsalu I, Punning A, Aabloo A. Charging a supercapacitor-like laminate with ambient moisture: from a humidity sensor to an energy harvester. Phys. Chem. Chem. Phys., 2013, 15(24):9605-9614.

75. Meng JP, Gong Y, Lin Q, Zhang MM, Zhang P, Shi HF, Lin JH. Metal-organic frameworks based on rigid ligands as separator membranes in supercapacitor. Dalton Trans., 2015, 44(12):5407-5416.

76. Sales BB, Saakes M, Post JW, Buisman CJ, Biesheuvel PM, Hamelers HV. Direct power production from a water salinity difference in a membrane-modified supercapacitor flow cell. Envir. Sci. Technol., 2010, 44(14):5661-5665.

77. Kiani MJ, Ahmadi MT, Karimi Feiz Abadi H, Rahmani M, Hashim A, Che Harun FK. Analytical modelling of monolayer graphenebased ion-sensitive FET to $\mathrm{pH}$ changes. Nanoscale Res. Lett., 2013, 8(1):173-1-173-9.

78. Johnson RN, Hanna GR. Membrane model: a single transistor analog of excitable membrane. J. Theor. Biol., 1969, 22(3):401-411.

79. Sibbald A, Covington AK, Carter RF. Simultaneous on-line measurement of blood $\mathrm{K}^{+}, \mathrm{Ca}^{2+}, \mathrm{Na}^{+}$, and $\mathrm{pH}$ with a four-function ChemFET integrated-circuit sensor. Clin. Chem., 1984, 30(1):135-137.

80. Sibbald A, Covington AK, Carter RF. Online patient-monitoring system for the simultaneous analysis of blood $\mathrm{K}^{+}, \mathrm{Ca}^{2+}, \mathrm{Na}^{+}$and $\mathrm{pH}$ using a quadruple-function ChemFET integrated-circuit sensor.Med.Biol.Eng. Comput., 1985,23(4):329-338.

81. Costa J, Fernandes M, Vieira M, Lavareda G, Karmali A. Membrane selectivity versus sensor response in hydrogenated amorphous silicon
ChemFETs using a semi-empirical model. J. Nanosci. Nanotechnol., 2011, 11(10):8844-8847.

82. Sun G, Senapati S, Chang HC. High-flux ionic diodes, ionic transistors and ionic amplifiers based on external ion concentration polarization by an ion exchange membrane: a new scalable ionic circuit platform. Lab Chip., 2016, 16(7):1171-1177.

83. Mo Y, Wan Y, Chau A, Huang F. Graphene/ Ionic liquid composite films and ion exchange. Sci. Rep., 2014, 4:5466-1-5466-8.

84. Chen G, Zhai S, Zhai Y, Zhang K, Yue Q, Wang L, Zhao J, Wang H, Liu J, Jia J. Preparation of sulfonic-functionalized graphene oxide as ion-exchange material and its application into electrochemiluminescence analysis. Biosens. Bioelectron., 2011, 26(7):3136-3141.

85. Zhang S, Shao Y, Liu J, Aksay IA, Lin Y. Graphenepolypyrrole nanocomposite as a highly efficient and low cost electrically switched ion exchanger for removing $\mathrm{ClO}_{4}^{-}$from wastewater. ACS Appl. Mat. Interf., 2011, 3(9):3633-3637.

86. Park JW, Park SJ, Kwon OS, Lee C, Jang J. Polypyrrole nanotube embedded reduced graphene oxide transducer for field-effect transistor-type $\mathrm{H}_{2} \mathrm{O}_{2}$ biosensor. Anal. Chem., 2014, 86(3):1822-1828.

87. Kwon OS, Park SJ, Hong JY, Han AR, Lee JS, Lee JS, Oh JH, Jang J. Flexible FET-type VEGF aptasensor based on nitrogen-doped graphene converted from conducting polymer. ACS Nano, 2012, 6(2):1486-1493.

88. Farid S, Meshik X, Choi M, Mukherjee S, Lan Y, Parikh D, Poduri S, Baterdene U, Huang CE, Wang YY, Burke P, Dutta M, Stroscio MA. Detection of Interferon gamma using graphene and aptamer based FET-like electrochemical biosensor. Biosens. Bioelectron., 2015, 71:294-299.

89. Park JW, Park SJ, Kwon OS, Lee C, Jang J. Highperformance $\mathrm{Hg}^{2+}$ FET-type sensors based on reduced graphene oxide-polyfuran nanohybrids. Analyst, 2014, 139(16):3852-3855.

90. Park SJ, Kwon OS, Lee SH, Song HS, Park TH, Jang J. Ultrasensitive flexible graphene based field-effect transistor (FET)-type bioelectronic nose. Nano Lett., 2012, 12(10):5082-5090.

91. Worley BC, Kim S, Park S, Rossky PJ, Akinwande D, Dodabalapur A. Dramatic vapor-phase modulation of the characteristics of graphene 
field-effect transistors. Phys. Chem. Chem. Phys, 2015, 17(28):18426-18430.

92. Min M, Seo S, Lee J, Lee SM, Hwang E, Lee H. Changes in major charge transport by molecular spatial orientation in graphene channel field effect transistors. Chem. Commun., 2013, 49(56):6289-6291.

93. Strejčková A, Staničová J, Jancura D, Miškovský P, Bánó G. Spatial orientation and electricfield-driven transport of hypericin inside of bilayer lipid membranes. J. Phys. Chem. B., 2013, 117(5):1280-1286.

94. Shen J, Liu G, Huang K, Jin W, Lee KR, Xu N. Membranes with fast and selective gas-transport channels of laminar graphene oxide for efficient $\mathrm{CO}_{2}$ capture. Angew. Chem. Int. Ed. Engl., 2015, 54(2):578-582.

95. Chen XC, Wei W, Lv W, Su FY, He YB, Li B, Kang F, Yang QH. A graphene-based nanostructure with expanded ion transport channels for high rate Li-ion batteries. Chem. Commun., 2012, 48(47):5904-5906.

96. Sun P, Zhu M, Wang K, Zhong M, Wei J, Wu $\mathrm{D}, \mathrm{Xu} \mathrm{Z}, \mathrm{Zhu} \mathrm{H}$. Selective ion penetration of graphene oxide membranes. ACS Nano, 2013, 7(1):428-437.

97. Sint K, Wang B, Král P. Selective ion passage through functionalized graphene nanopores. J. Am. Chem. Soc., 2008, 130(49):16448-16449.

98. Boukhvalov DW, Virojanadara C. Penetration of alkali atoms throughout a graphene membrane: theoretical modeling. Nanoscale, 2012, 4(5):1749-1753.

99. He Z, Zhou J, Lu X, Corry B. Bioinspired graphene nanopores with voltage-tunable ion selectivity for $\mathrm{Na}^{+}$and $\mathrm{K}^{+}$. ACS Nano, 2013, 7(11):10148-10157.

100. Grahame-Smith DG, Wang H. Comparison of the actions of lithium, rubidium, and caesium on rat brain 5-HT function: pharmacological implications of ion channel function. Clin. Neuropharmacol., 1992, 15(Suppl. 1):614A-615A.

101. Boccaccio A, Conti F, Olivera BM, Terlau $\mathrm{H}$. Binding of kappa-conotoxin PVIIA to Shaker $\mathrm{K}^{+}$channels reveals different $\mathrm{K}^{+}$and $\mathrm{Rb}^{+}$ occupancies within the ion channel pore. J. Gen. Physiol., 2004, 124(1):71-81.

102. Mao G, Winokur MJ, Karasz FE. Dual alkali-metal-ion channel structures in poly(p-phenylenevinylene). Phys. Rev. B: Cond. Matt., 1996, 53(2):R463-R467.

103. Miller C, Stahl N, Barrol M. A thermodynamic analysis of monovalent cation permeation through a $\mathrm{K}^{+}$-selective ion channel. Neuron, 1988, 1(2):159-164.

104. Billes F, Mohammed-Ziegler I, Mikosch H. Transportation behavior of alkali ions through a cell membrane ion channel. A quantum chemical description of a simplified isolated model. J. Mol. Model., 2012, 18(8):3627-3637.

105. Hilder TA, Gordon D, Chung SH. Synthetic chloride-selective carbon nanotubes examined by using molecular and stochastic dynamics. Biophys. J., 2010, 99(6):1734-1742.

106. Middleton RE, Pheasant DJ, Miller C. Homodimeric architecture of a ClC-type chloride ion channel. Nature, 1996, 383(6598):337-340.

107. Li Y, Yeo GF, Milne RK, Madsen BW, Edeson RO. Burst properties of a supergated double-barrelled chloride ion channel. Math. Biosci., 2000, 166(1):23-44.

108. Franco A, Winegar BD, Lansman JB. Open channel block by gadolinium ion of the stretchinactivated ion channel in $\mathrm{mdx}$ myotubes. Biophys. J., 1991, 59(6):1164-1170.

109. Wang K, McIlvain B, Tseng E, Kowal D, Jow F, Shen R, Zhang H, Shan QJ, He L, Chen D, Lu Q, Dunlop J. Validation of an atomic absorption rubidium ion efflux assay for $\mathrm{KCNQ} / \mathrm{M}$ channels using the ion Channel Reader 8000. Assay Drug Dev. Technol., 2004, 2(5):525-534.

110. Massobrio G, Massobrio P, Martinoia S. Modeling the neuron-carbon nanotube-ISFET junction to investigate the electrophysiological neuronal activity. Nano Lett., 2008, 8(12):4433-4440.

111. Martinoia S, Massobrio P. ISFET-neuron junction: circuit models and extracellular signal simulations. Biosens. Bioelectron., 2004, 19(11):1487-1496.

112. Li Z, Wang C, Tian L, Bai J, Yao H, Zhao Y, Zhang X, Cao S, Qi W, Wang S, Shi K, Xu Y, Mingliang Z, Liu B, Qiu H, Liu J, Wu W, Wang X, Wenzhen A. An embryo of protocells: The capsule of graphene with selective ion channels. Sci. Rep., 2015, 5:10258-1-10258-14.

113. Li Z, Wang C, Tian L, Bai J, Yao H, Zhao Y, Zhang X, Cao S, Qi W, Wang S, Shi K, Xu 
Y, Mingliang Z, Liu B, Qiu H, Liu J, Wu W, Wang X, Wenzhen A. Corrigendum: An embryo of protocells: The capsule of graphene with selective ion channels. Sci. Rep., 2015, 5:12386.

114. Stillwell W. Facilitated diffusion as a method for selective accumulation of materials from the primordial oceans by a lipid-vesicle protocell. Orig. Life., 1980, 10(3):277-292.

115. Liu J, Stace-Naughton A, Jiang X, Brinker CJ. Porous nanoparticle supported lipid bilayers (protocells) as delivery vehicles. J. Am. Chem. Soc., 2009, 131(4):1354-1355.

116. Walde P. Building artificial cells and protocell models: experimental approaches with lipid vesicles. Bioessays, 2010, 32(4):296-303.

117. Li M, Huang X, Tang TY, Mann S. Synthetic cellularity based on non-lipid microcompartments and protocell models. Curr. Opin. Chem. Biol., 2014, 22:1-11.

118. Koga S, Williams DS, Perriman AW, Mann S. Peptide-nucleotide microdroplets as a step towards a membrane-free protocell model. Nat. Chem., 2011, 3(9):720-724.

119. Li M, Harbron RL, Weaver JV, Binks BP, Mann S. Electrostatically gated membrane permeability in inorganic protocells. Nat. Chem., 2013, 5(6):529-536.

120. Cooper GJ, Kitson PJ, Winter R, Zagnoni M, Long DL, Cronin L. Modular redox-active inorganic chemical cells: iCHELLs. Angew. Chem. Int. Ed. Engl., 2011, 50(44):10373-10376.

121. Kumar RK, Li M, Olof SN, Patil AJ, Mann S. Artificial cytoskeletal structures within enzymatically active bio-inorganic protocells. Small, 2013, 9(3):357-362.

122. Gupta VK. Emergence of photoautotrophic minimal protocell-like supramolecular assemblies, "Jeewanu" synthesied photo chemically in an irradiated sterilised aqueous mixture of some inorganic and organic substances. Orig. Life Evol. Biosph., 2014, 44(4):351-355.

123. Kaur G, Rath G, Heer H, Goyal AK. Optimization of protocell of silica nanoparticles using $3^{2}$ factorial designs. AAPS PharmSciTech., 2012, 13(1):167-173.

124. Yasaei P, Kumar B, Hantehzadeh R, Kayyalha M, Baskin A, Repnin N, Wang C, Klie RF, Chen YP, Král P, Salehi-Khojin A. Chemical sensing with switchable transport channels in grapheme grain boundaries. Nat. Commun., 2014, 5:4911.

125. Rickhaus P, Liu MH, Makk P, Maurand R, Hess S, Zihlmann S, Weiss M, Richter K, Schönenberger C. Guiding of Electrons in a Few-Mode Ballistic Graphene Channel. Nano Lett., 2015, 15(9):5819-5825.

126. Cantele G, Lee YS, Ninno D, Marzari N. Spin channels in functionalized graphene nanoribbons. Nano Lett., 2009, 9(10):3425-3429.

127. Archer SJ, Ellena JF, Cafiso DS. Dynamics and aggregation of the peptide ion channel alamethicin. Measurements using spin-labeled peptides. Biophys. J., 1991, 60(2):389-398.

128. Perozo E, Cuello LG, Cortes DM, Liu YS, Sompornpisut P. EPR approaches to ion channel structure and function. Novartis Found Symp., 2002, 245:146-168.

129. Holt SA, Le Brun AP, Majkrzak CF, McGillivray DJ, Heinrich F, Lösche M, Lakey JH. An ion-channel-containing model membrane: structural determination by magnetic contrast neutron reflectometry. Soft Matter, 2009, 5(13):2576-2586.

130. Endeward B, Butterwick JA, MacKinnon R, Prisner TF. Pulsed electron-electron doubleresonance determination of spin-label distances and orientations on the tetrameric potassium ion channel KcsA. J. Am. Chem. Soc., 2009, 131(42):15246-15250.

131. Dellisanti CD, Ghosh B, Hanson SM, Raspanti JM, Grant VA, Diarra GM, Schuh AM, Satyshur K, Klug CS, Czajkowski C. Sitedirected spin labeling reveals pentameric ligandgated ion channel gating motions. PLOS Biol., 2013, 11(11):e1001714, 1-14.

132. Mirsaidov U, Mokkapati VR, Bhattacharya D, Andersen H, Bosman M, Özyilmaz B, Matsudaira P. Scrolling graphene into nanofluidic channels. Lab Chip, 2013, 13(15):2874-2878.

133. Montenegro J, Ghadiri MR, Granja JR. Ion channel models based on self-assembling cyclic peptide nanotubes. Acc. Chem. Res., 2013, 46(12):2955-2965.

134. Mayer M, Semetey V, Gitlin I, Yang J, Whitesides GM. Using ion channel-forming peptides to quantify protein-ligand interactions. J. Am. Chem. Soc., 2008, 130(4):1453-1465. 
135. Sánchez-Quesada J, Isler MP, Ghadiri MR. Modulating ion channel properties of transmembrane peptide nanotubes through heteromeric supramolecular assemblies. J. Am. Chem. Soc., 2002, 124(34):10004-10005.

136. Ichikawa T, Yoshio M, Hamasaki A, Mukai T, Ohno H, Kato T. Self-organization of roomtemperature ionic liquids exhibiting liquidcrystalline bicontinuous cubic phases: formation of nano-ion channel networks. J. Am. Chem. Soc., 2007, 129(35):10662-10663.

137. Cazacu A, Tong C, van der Lee A, Fyles TM, Barboiu M. Columnar self-assembled ureido crown ethers: an example of ion-channel organization in lipid bilayers. J. Am. Chem. Soc., 2006, 128(29):9541-9548.

138. Nyitrai G, Keszthelyi T, Bóta A, Simon A, Tőke O, Horváth G, Pál I, Kardos J, Héja L. Sodium selective ion channel formation in living cell membranes by polyamidoamine dendrimer. Biochim. Biophys. Acta., 2013, 1828(8):1873-1880.

139. Abhilash TS, De Alba R, Zhelev N, Craighead HG, Parpia JM. Transfer printing of CVD graphene FETs on patterned substrates. Nanoscale, 2015, 7(33):14109-14113.

140. Ping J, Wang Y, Ying Y, Wu J. Application of electrochemically reduced graphene oxide on screen-printed ion-selective electrode. Anal. Chem., 2012, 84(7):3473-3479.

141. Lukas M, Meded V, Vijayaraghavan A, Song L, Ajayan PM, Fink K, Wenzel W, Krupke R. Catalytic subsurface etching of nanoscale channels in graphite. Nat. Commun., 2013; 4:1379.

142. Choi BS, Kim SM, Gong J, Lee YW, Kang SW, Lee HS, Park JY, Han SW. One-pot selftemplating synthesis of Pt hollow nanostructures and their catalytic properties for CO oxidation. Chemistry, 2014, 20(37):11669-11674.

143. Yang F, Zhou S, Wang H, Long S, Liu X, Kong Y. A metal-assisted templating route $\left(\mathrm{S}^{0} \mathrm{M}^{+} \mathrm{I}^{-}\right)$for fabricating thin-layer $\mathrm{CoO}$ covered on the channel of nanospherical-HMS with improved catalytic properties. Dalton Trans., 2016, 45(15):6371-6382.

144. Li Y, Guijarro N, Zhang X, Prévot MS, Jeanbourquin XA, Sivula K, Chen $H$, Li Y. Templating Sol-Gel Hematite Films with Sacrificial Copper Oxide: Enhancing Photoanode Performance with Nanostructure and Oxygen Vacancies. ACS Appl. Mat. Interf., 2015, 7(31):16999-17007.

145. Martin JD, Keary CL, Thornton TA, Novotnak MP, Knutson JW, Folmer JC. Metallotropic liquid crystals formed by surfactant templating of molten metal halides. Nat. Mater., 2006, 5(4):271-275.

146. Moon GH, Shin Y, Choi D, Arey BW, Exarhos GJ, Wang C, Choi W, Liu J. Catalytic templating approaches for three-dimensional hollow carbon/graphene oxide nano-architectures. Nanoscale, 2013, 5(14):6291-6296.

147. Chaloin L, Méry J, Van Mau N, Divita G, Heitz F. Synthesis of a template-associated peptide designed as a transmembrane ion channel former. J. Pept. Sci., 1999, 5(9):381-391.

148. Wang Y, Ma S, Su Y, Han X. Palladium nanotubes formed by lipid tubule templating and their application in ethanol electrocatalysis. Chemistry, 2015, 21(16):6084-6089.

149. Inesi G, Kirtley ME. Coupling of catalytic and channel function in the $\mathrm{Ca}^{2+}$ transport ATPase. J. Membr. Biol., 1990, 116(1):1-8.

150. Hsu CM, Rosen BP. Characterization of the catalytic subunit of an anion pump. J. Biol. Chem., 1989, 264(29):17349-17354.

151. Ramjeesingh M, Li C, Garami E, Huan LJ, Galley K, Wang Y, Bear CE. Walker mutations reveal loose relationship between catalytic and channel-gating activities of purified CFTR (cystic fibrosis transmembrane conductance regulator). Biochemistry, 1999, 38(5):1463-1468.

152. Csanády L, Vergani P, Gadsby DC. Strict coupling between CFTR's catalytic cycle and gating of its $\mathrm{Cl}$ - ion pore revealed by distributions of open channel burst durations. Proc. Nat. Acad. Sci. USA, 2010, 107(3):1241-1246.

153. Bienengraeber M, Alekseev AE, Abraham MR, Carrasco AJ, Moreau C, Vivaudou M, Dzeja PP, Terzic A. ATPase activity of the sulfonylurea receptor: a catalytic function for the KATP channel complex. FASEB J., 2000, 14(13):1943-1952.

154. Park S, Lim BB, Perez-Terzic C, Mer G, Terzic A. Interaction of asymmetric ABCC9-encoded nucleotide binding domains determines KATP channel SUR2A catalytic activity. J. Proteome Res., 2008, 7(4):1721-1728. 
155. Behera RK, Theil EC. Moving $\mathrm{Fe}^{2+}$ from ferritin ion channels to catalytic $\mathrm{OH}$ centers depends on conserved protein cage carboxylates. Proc. Nat. Acad. Sci. USA, 2014, 111(22):7925-7930.

156. Theil EC. Ferritin protein nanocages use ion channels, catalytic sites, and nucleation channels to manage iron/oxygen chemistry. Curr. Opin. Chem. Biol., 2011, 15(2):304-311.

157. Sakai N, Sordé N, Matile S. Synthetic catalytic pores. J. Am. Chem. Soc., 2003, 125(26):7776-7777.

158. Sharma V, Wikström M. The role of the $\mathrm{K}$-channel and the active-site tyrosine in the catalytic mechanism of cytochrome c oxidase. Biochim. Biophys. Acta., 2016, 1857(8):1111-1115.

159. Chakrabarti N, Ing C, Payandeh J, Zheng $\mathrm{N}$, Catterall WA, Pomès R. Catalysis of $\mathrm{Na}^{+}$ permeation in the bacterial sodium channel $\mathrm{Na}(\mathrm{V})$ Ab. Proc. Nat. Acad. Sci. USA, 2013, 110(28):11331-11336.

160. Lim C, Dudev T. Potassium Versus Sodium Selectivity in Monovalent Ion Channel Selectivity Filters. Met. Ions Life Sci., 2016, 16:325-347.

161. Zacharias N, Dougherty DA. Cation-pi interactions in ligand recognition and catalysis. Trends Pharmacol Sci., 2002, 23(6):281-287.

162. Okamura Y. Lipids: PI couples voltage to catalysis. Nat. Chem. Biol., 2010, 6(5):315-316.

163. Kohout SC, Bell SC, Liu L, Xu Q, Minor DL, Isacoff EY. Electrochemical coupling in the voltage-dependent phosphatase Ci-VSP. Nat. Chem. Biol., 2010, 6(5):369-375.

164. Dhindwal S, Priyadarshini P, Patil DN, Tapas S, Kumar P, Tomar S, Kumar P. Ligand-bound structures of 3-deoxy-D-manno-octulosonate 8-phosphate phosphatase from Moraxella catarrhalis reveal a water channel connecting to the active site for the second step of catalysis. Acta Crystallogr. D: Biol. Crystallogr., 2015, 71(2):239-255.

165. Marti J, Nagy G, Gordillo MC, Guàrdia E. Molecular simulation of liquid water confined inside graphite channels: thermodynamics and structural properties. J. Chem. Phys., 2006, 124(9):94703-1-94703-7.

166. Thekkethala JF, Sathian SP. Thermal transpiration through single walled carbon nanotubes and graphene channels. J. Chem. Phys., 2013, 139(17):174712-1-174712-9.
167. Leung SS, Sindhikara D, Jacobson MP. Simple Predictive Models of Passive Membrane Permeability Incorporating Size-Dependent Membrane-Water Partition. J. Chem. Inf. Model., 2016, 56(5):924-929.

168. Kreida S, Törnroth-Horsefield S. Structural insights into aquaporin selectivity and regulation. Curr. Opin. Struct. Biol., 2015, 33:126-134.

169. Jang M, Trung TQ, Jung JH, Kim BY, Lee NE. Improved performance and stability of field-effect transistors with polymeric residuefree graphene channel transferred by gold layer. Phys. Chem. Chem. Phys., 2014, 16(9):4098-4105.

170. Ramesh P, Itkis ME, Bekyarova E, Wang F, Niyogi S, Chi X, Berger C, de Heer W, Haddon RC. Electro-oxidized epitaxial graphene channel field-effect transistors with single-walled carbon nanotube thin film gate electrode. J. Am. Chem. Soc., 2010, 132(41):14429-14436.

171. Li SL, Miyazaki H, Hiura H, Liu C, Tsukagoshi K. Enhanced logic performance with semiconducting bilayer graphene channels. ACS Nano, 2011, 5(1):500-506.

\section{Градов Олег Валерьевич}

к.ф.-м.н., с.н.с.

Институт энергетических проблем химической физики им. В.А.Тальрозе РАН

38/2, Аенинский просп., Москва 117829, Россия gradov@chph.ras.ru

Градова Маргарита Алексеевна

א.X.H., c.H.C.

Институг химической физики им. Н.Н. Семенова РАН 4, ум. Косыгина, Москва 119991, Россия gradova@chph.ras.ru 


\section{CAN GRAPHENE BILAYERS BE THE MEMBRANE MIMETIC} MATERIALS? ION CHANNELS IN GRAPHENE-BASED NANOSTRUCTURES

\section{Oleg V. Gradov}

Institute of Energy Problems of Chemical Physics, Russian Academy of Sciences, http://www.inepcp.ru 117829 Moscow, Russian Federation

gradov@chph.ras.ru

\section{Margaret A. Gradova}

Semenov Institute of Chemical Physics, Russian Academy of Sciences, http://www.chph.ras.ru 119991 Moscow, Russian Federation

Institute of Energy Problems of Chemical Physics, Russian Academy of Sciences, http://www.inepcp.ru 117829 Moscow, Russian Federation gradova@chph.ras.ru

Abstract. The prospects of application of graphene and related structures as the membrane mimetic materials, capable of reproducing several biomembrane functions up to the certain limit, are analyzed in the series of our papers. This paper considers the possibility of the ion channel function modeling using graphene and its derivatives. The physical mechanisms providing selective permeability for different membrane mimetic materials, as well as the limits of the adequate simulation of the transport, catalytic, sensing and electrogenic properties of the cell membrane ion channels using bilayered graphene-based structures are discussed.

Keywords: ion channels, graphene, channel mimetics, nanopores, kapillarchemie, size-dependent electrochemistry, electric double-layer capacitor, ISFET \& ChemFET

PACS: 81.05.ue

Bibliography - 171 references 


\section{АИСПЕРСИИ НАНОЧАСТИЦ В ВОАНО-ОРГАНИЧЕСКИХ РАСТВОРИТЕАЯХ КАК ОСНОВА СЕРЕБРЯНЫХ НАНОЧЕРНИА

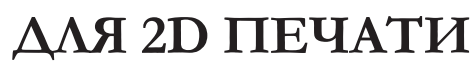

\author{
1,2Ткачев С.В., ${ }^{1}$ Ким В.П., ${ }^{1}$ Кушнир А.Е., ${ }^{1}$ Корнимов А.Ю., ${ }^{1,2}$ Губин С.П. \\ ${ }^{1} \mathrm{OOO} \mathrm{"АкКо} \mathrm{\Lambda аб",} \mathrm{http:/} \mathrm{/} \mathrm{www.akkolab.ru}$ \\ 129110 Москва, Российская Федерация \\ ${ }^{2}$ Институт общей и неорганической химии им. Н.С. Курнакова Российской академии наук, http:/ / www.igic.ras.ru \\ 117991 Москва, Российская Федерация \\ Поступила 05.12.2016
}

Работа направлена на решение задачи создания функциональных серебряных наночерним, используемых в технологии струйной печати микроэлектронных устройств гибкой эмектроники, а также на демонстрацию результатов печати и их обсуждение. Создание печатающих функциональных составов - это принципиально новых подход к производству устройств гибкой эмектроники ААя оборонной и гражАанской промышленности. В рамках проводимой работы удемяется особое внимание получению водных и органических Аисперсий серебряных наночастиц, изучению размичных факторов, вАияющих на размер и характеристики получаемых наночастиц, методам концентрирования стандартных Аисперсий А^я получения наночерния, печати токопроводящих структур синтезированными наночернияами и исследованию свойств напечатанных элементов. Полученные результаты работы позволяют создать серебряные наночернила и аАаптировать их Аля печати специализированными принтерами на различных подможках, в том числе, и гибких полимерных.

Ключевые слова: серебряные наночернила, водные дисперсии, струйная печать, токопроводящие структуры, полимерные подможки, гибкая эмектроника Амя печати

\section{УАК 546.57, 621.3.049.7}

\section{СОДЕРЖАНИЕ}

1. ВВеАЕНИЕ (171)

2. ЭКСПЕРИМЕНТААЬНАЯ ЧАСТЬ (173)

2.1. Получение разбавленных водных Аисперсий наночастиц серебра (173)

2.2. Получение серебряных наночернил (174)

3. РезУаьтаты и обСУжАЕние (174)

3.1. Струйная печать серебряными наночерниками (176)

3.2. Обработка подАожек в плазме (176)

3.3. Термообработка (177)

3.4. Печать серебряными наночерниками токопроводящих миний на поверхности ITO (178)

3.5. Печать серебряными наночернимами токопроводящих миний на поверхности кремния (179)

3.6. Печать нагревательных элементов на полимерной пменке (180)

3.7. Печать токопроводящих плат сложной геометрии на разАичных подАожках (180)

3.8. Печать серебряными наночернилами на текстильных изделиях (182)

4. ЗАКАЮЧЕНИЕ (182)

АИТЕРАТУРА (182)

\section{1. ВВЕАЕНИЕ \\ Гибкая печатная электроника - это новое перспективное направление по созданию микроэлектронных гибких устройств печатными аААИТИвНЫМИ ТеХНОАОГИяМИ слеАУЮщеГО поколения, в том числе, струйной печатью [1]. Созданием и разработкой гибких электронных устройств методом прецизионной аАдитивной печати с помощью специализированных принтеров в настоящее время занимаются крупные иностранные корпорации,} заинтересованные коммерческие организации и отдельные научные группы.

Интенсивное развитие обсуждаемого направления в микроэлектронике обусловлено резким увеличением количества научных публикаций, ежемесячно посвященных созАанию печатных микроэлектронных устройств.

Актуальность использования методов аАдитивной печати обусловлена рядом преимушеств: расширение технологических 
возможностей применения гибких электронных устройств; упрощение технологического цикла проектирования и изготовления электронных плат; сокращение количества технологических операций; снижение энергозатрат; существенное повышение экологичности технологического процесса.

На сегодняшний Аень значительная работа ученых и конструкторов в области печатной и гибкой электроники направлена на разработку новых функциональных материалов - наночерниц, которые позволили бы превзойти по ряду критических параметров соответствующие твердотельные электронные аналоги, произведенные традиционными методами. Так, в зависимости от типа использования разрабатываются наночернила специального назначения - проводящие, на основе металлических наночастиц (преимущественно, на основе наночастиц серебра), полупроводниковые, магнитные и углеродные на основе графена и его родственных нанобъектов и нанотрубок $[2,3]$. Следует отметить, что в большинстве задач принтерной электроники требуются серебряные наночерника.

Так, в Аанной работе представлены результаты компании ООО «АкКо Ааб̈ по разработке серебряных наночернил, аАаптированных Аля печати на имеющемся высокотехнологичном оборудовании Dimatix Materials Printer 2831, а также результаты печати различных структур на подложках разной природы и их обсуждение.

С точки зрения химии, серебряные наночернила - это высококонцентрированные Аисперсии серебряных наночастиц. Как правило, массовое содержание наночастиц серебра в таких системах составцяет более 5-10 масс. \%. Получение разбавленных Аисперсий серебряных наночастиц в настоящее время Аостаточно хорошо разработано, существует большое количество различных методик и вариантов их получения. ОАнако, есть трудности с получением высококонцентрированных Аисперсий наночастиц серебра, пригодных, в частности, А^я печати токопроводящей разводки методом струйной печати. Кроме того, например, Аля использования наночернил в картриджах струйных принтеров Dimatix предъяв яяется ряд требований, согласно которым используемые наночернила Аолжны иметь вязкость 10-20 сП, поверхностное натяжение 28-33 Аин/см и значение $\mathrm{pH}$ 4-9, размер частиц, предпочтительно, менее 50 нм, обуславливающих успешное пропускание чернил через Аюзы размером около 17 мкм, а также отсутствие в составе наночернил вредных и ядовитых веществ.

Также необходимо отметить, что использование в печати наночернил на основе различных нанообъектов обосновано прецизионной микропечатью и уникальными свойствами наноматериалов по сравнению с их аналогичными компактными веществами. Стоит отметить, что на сегодняшний день на мировом рынке присутствуют только некоторые, наиболее простые по составу наночернила, преимущественно серебряные [4]. Основными трудностями при синтезе наночернил, аАаптированных Аля струйной печати, как правило, явцяются: стабилизация отАельных наночастиц при повышении их концентрации в Аисперсии (вплоть до нескольких Аесятков массовых процентов вещества), Аостижение необходимого поверхностного натяжения, вязкости наночернил. Решаются эти трудности не только подбором условий проведения синтеза (продолжительность, температура, концентрации компонентов), но и выбором и использованием разАичных типов поверхностно-активных веществ, растворителей. В целом, многиеметоды являются оригинальными, поскольку наночернила явАяются сложными многокомпонентными растворами.

Новизна работы состоит в разработке новых оригинальных по составу высококонцентрированных Аисперсий функциональных серебряных наночастиц, позволяющих создавать методом принтерной печати элементы гибких электронных устройств.

На сегодняшний день такие крупные компании как «Fujifilm», «Novacentrix»,

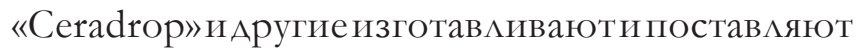
принтеры, способные производить печать наночернилами произвольных по геометрии 
рисунков. Причем заправка соответствующего картриджа возможна Аюбыми наночернилами, уАовлетворяющими требованиям печати, и выбор подложек ничем не ограничен. На Аанный момент точность печати таких принтеров не превышает нескольких микрон, а минимальные размеры отАельной капли больше 15 мкм. Это связано с размерами дюз (сопел) картриджа, поверхностным натяжением и вязкостью наночерниц, аАгезионными свойствами поАложки и точностью шаговых Авигателей принтера. В настоящее время, используя подобные печатные установки и наночернила, специализирующиеся компании и отдельные научные колмективы осуществляют печать большей части элементной базы микроэлектроники: конденсаторы, аккумуляторы, токопроводящие разводки, светодиоды и прочее [5-7]. Наряду с этим в митературе описаны эксперименты по печати светодиодов, транзисторов на гибких прозрачных полимерных носителях. Масштабное производство с применением печатных аАдитивных технологий возможно при использовании roll-to-roll технологии, гАе в качестве подложки используется рулон необходимого материала. Аанная технология способна производить печать и Аальнейшую температурную (термическую, световую и пр.) обработку электронных устройств со скоростью Подачи ПоАлОжки в несколько метров в минуту.

Совмещение

функциональных наночернил (со свойствами проводников, полупроводников и Аиэлектриков) с современными печатными установками может существенно снизить стоимость электронной продукции, увеличить эффективность их производства, позволит производить устройства гибкой электроники.

Технология струйной печати отличается от традиционных технологий электронной промышленности (фотолитографии и пр.) низкой стоимостью производства, возможностью работы с Аюбым типом подложек, причем подложки в Аанной технологии не претерпевают значительных воздействий. Таким образом, технология позволяет создавать гибкие, прозрачные электронные устройства с относительно низкой стоимостью. Конечным продуктом в технологии струйной печати явАяются батареи, аккумуляторы, конденсаторы, тонкопленочные транзисторы, Аисплеи, сенсоры, антенны, солнечные батареи, соединительные элементы в микросхемах и т.А. [8].

Постановка задачи в рамках данной работы заключается в необходимости создать массовое производство серебряных наночернил, устойчивых при хранении и транспортировке, пригодных Аля струйной печати проводящих структур на различных (в том числе - гибких) подложках современными 2D принтерами.

В статье показано, как с использованием ПОАХОАОВ и меТОАОВ КОААОИАНОЙ Химии можно подойти к решению поставленной задачи, продемонстрированы результаты печати некоторых элементов и измерены их характеристики.

\section{2. ЭКСПЕРИМЕНТААЬНАЯ ЧАСТЬ}

Прекурсорами Аля получения серебряных наночернил явцялись нитрат серебра (х.ч., ОА «Бертуз»), ацетат серебра ( $\geq 99.0 \%$, CAS-No.: 563-63-3, Sigma Aldrich), Авухводный цитрат натрия (99,0\%, CAS-No.: 6132-04-3, Panreac), борогиариа натрия (96\%, CAS-No.: 16940-662, Panreac), этиленгликоль (ч.А.а., CAS-No.: 107-21-1, 3АО «Экос 1») и Аеионизированная BOAa.

\section{1. ПОАУЧЕНИЕ РАЗБАВАЕННЫХ ВОАНЫХ АИСПЕРСИЙ НАНОЧАСТИЦ СЕРЕБРА}

В типичном эксперименте В плоскодонной колбе растворяли 4 г порошка цитрата натрия в Аеионизованной воде при постоянном перемешивании. Затем готовили раствор, содержащий 0.5 г нитрата серебра и ацетата серебра в деионизованной воде, и небольшими порциями Аобавляли в раствор цитрата натрия при постоянном перемешивании. Аополнительно готовили $0.2 \mathrm{M}$ водный раствор боргилрила натрия. Аалее, в раствор цитрата натрия, нитрата и ацетата серебра покапельно Аобавляли свежеприготовленный раствор борогидрида натрия. При этом Аисперсия образующихся наночастиц серебра приобретала интенсивный темно-коричневый цвет. В итоге получали стандартные водные Аисперсии 
серебряных наночастиц с содержанием серебряных наночастиц 0.03 масс. \%.

\section{2 ПОАУЧЕНИЕ СЕРЕБРЯНЫХ НАНОЧЕРНИА}

Аля получения серебряных наночернил центрифугировали стандартную Аисперсию серебряных наночастиц в течение 20 мин при 15000 об/мин. Аамее супернатант Аекантировали и собирали образовавшуюся высококонцентрированную жидкость, состоящую из серебряных наночастиц. Затем, снова повторяли операцию центрифугирования. В полученный концентрат серебряных наночастиц АобавАяли ПАВ, в том числе, этиленгликоль, необходимый Аля стабилизации полученных серебряных наночастиц. Затем полученную высококонцентрированную Аисперсию наночастиц в этиленгликоле пропускали через фильтр с размером пор 0.22 мкм и получали готовые серебряные наночернила.

Морфологию и состав получаемых в работе нанообъектов исследоваци методами сканирующей эмектронной микроскопии (сканирующий зондовый микроскоп Carl Zeiss Supra 40-30-87, Германия), атомно-силовой микроскоп Solver P47, OOO NT-MDT, Россия) и просвечивающей эмектронной микроскопии (просвечивающий эмектронный микроскоп JEOL 2000FX, Германия), рентгенофазового анализа (Аифрактометр Bruker Advanced 8, CuK $\lambda$ измучение, $\lambda=1.5418 \AA$ ), спектрофотометрии (спектрофотометр Leki SS2107UV, 3AO «АОИП», Россия)

\section{3. РЕЗУАЬТАТЫ И ОБСУЖАЕНИЕ}

Необходимо заметить, что структура и спектральные свойства наночастиц Аостаточно сильно зависят не только от состава и свойств среды, в которой они Аиспергированы, но и от условий синтеза, использования тех или иных стабилизаторов, растворителей, концентрации исходных реагентов и т.А. В связи с тем, что образование наночастиц протекает по известным стандартным методикам, остается открытым вопрос о том, возможно $\Lambda$ сохранение состава, структуры и специфических оптикофизических характеристик исходных наночастиц при переходе в конечный продукт
- высококонцентрированные Аисперсии этих наночастиц - наночернила. Усилия авторов направлены на то, чтобы в настоящей работе зафиксировать возможность получения серебряных наночернил с сохранением их основных свойств из стандартных серебряных Аисперсий в водной среде, а также продемонстрировать и обсудить результаты печати синтезированными наночернилами на принтере Dimatix Materials Printer 2831 токопроводящих структур.

На рис. 1 представлены типичные спектры поглощения от Алины волны Аля разбавленных образцов стандартной Аисперсии серебряных наночастиц и наночернил, полученных из Аанной Аисперсии. Максимум поглощения приходится на Алину волны в 388 нм, что, согласно митературным данным, соответствует среднему размеру наночастиц 10 нм.

Из анализа спектров видно, что операции центрифугирования и концентрирования стандартной Аисперсии серебряных наночастиц приводят не только к увеАичению концентрации целевых наночастиц в наночернилах, но и к более выраженной монодисперсности продукта по сравнению с исходной Аисперсией.

Согласно Аанным рентгенофазового анализа рефлексы кристаллической структуры серебряных наночастиц, вылеленных как из стандартной Аисперсии серебряных наночастиц, так и из серебряных наночернил и далее выдержанных при температуре $100^{\circ} \mathrm{C}$, полностью соответствуют фазе массивного

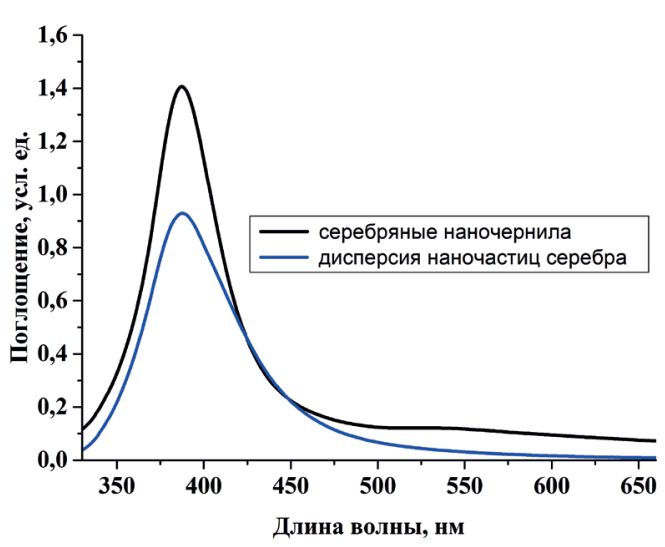

Рис. 1. Типичные спектры поглочения разбавленных дисперсий серебряных наночастич и наночернил. 


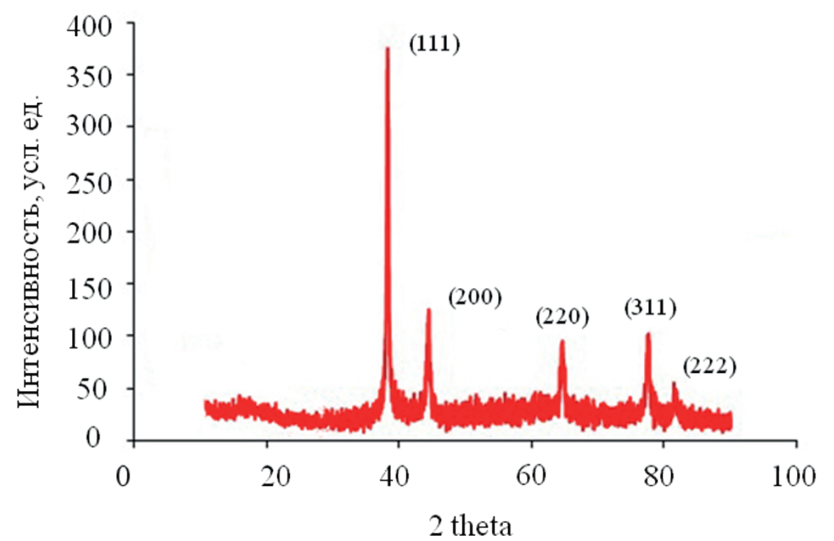

Рис. 2. Аифрактограмма серебряных наночастии, полученныхх термической обработкой аликвоть серебряных наночернил при $\mathrm{T}=100^{\circ} \mathrm{C}$ в течение 30 мин.

серебра (карточка PDF\#030921, база Аанных International Centre for Diffraction Data). Ha рис. 2 приведена Аифрактограмма серебряных наночастиц, полученных термической обработкой аликвоты серебряных наночернил при температуре $100^{\circ} \mathrm{C}$.

Исследование образцов серебряных наночастиц методом просвечивающей электронной микроскопии показало, что Аисперсии серебряных наночастиц и наночернил состоят из изотропных наночастиц (рис. 3). Причем, форма частиц Аостаточно однородна и близка к сферической. Согласно результатам электронограмм, полученных методом ПЭМ, наночастицы серебра имеют кристалиическую природу. Так, имеющиеся кольцевидные

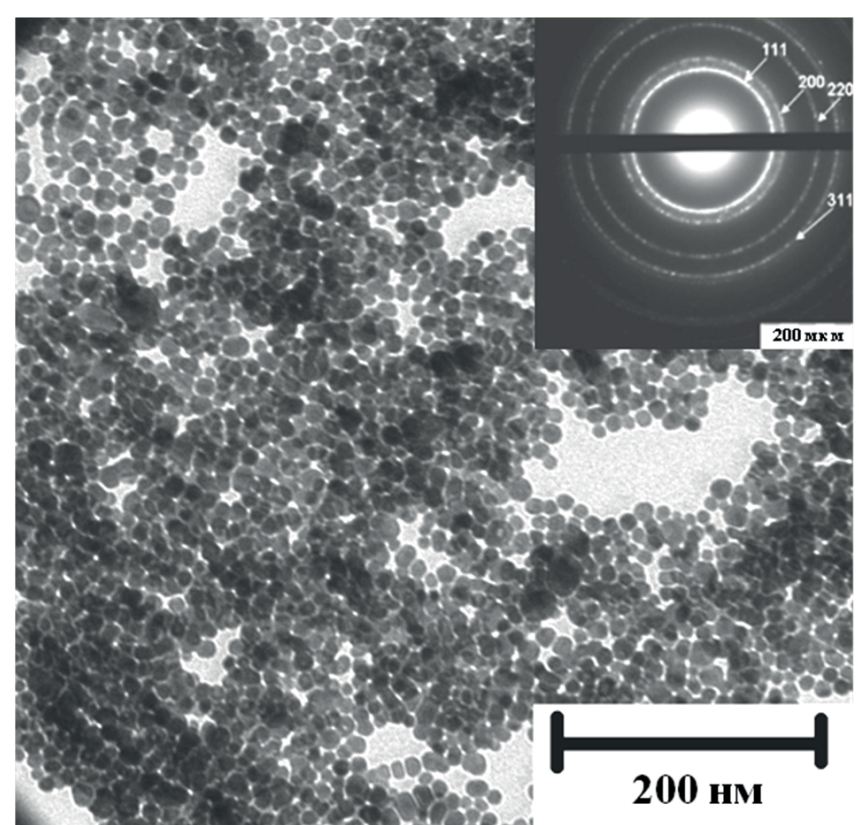

Рис. 3. ПЭМ-изображение и электронная дифракиия наночастии серебра из серебряных наночернил.

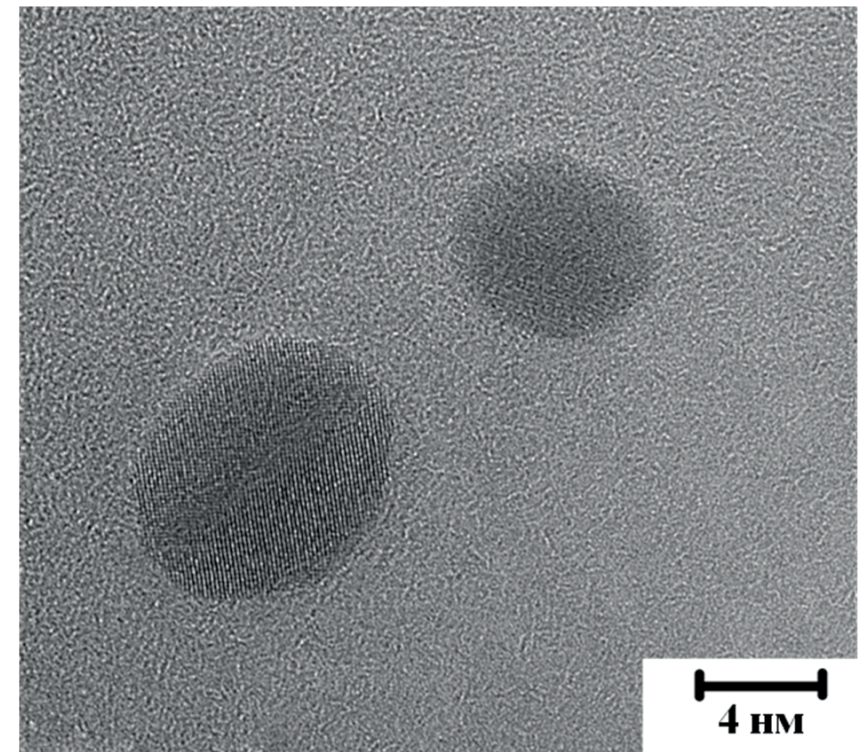

Рис. 4. ПЭМ-изображение высокого разрешения наночастич серебра из серебряных наночастич.

рефлексы на электронограмме илентифицируют фазу компактного серебра и однофазность образца.

Было показано, что результаты, полученные методом ПЭМ, согласуются с результатами спектрофотометрии.

На рис. 4 представлена просвечивающая электронная микроскопия высокого разрешения Аля Авух наночастиц серебра. На изображении отчетливо видна структура и форма серебряных наночастиц.

Построение и анализ гистограммы (рис. 5) распределения серебряных наночастиц по размерам позволил установить, что средний размер частиц серебра составцяет $10 \pm 2$ нм,

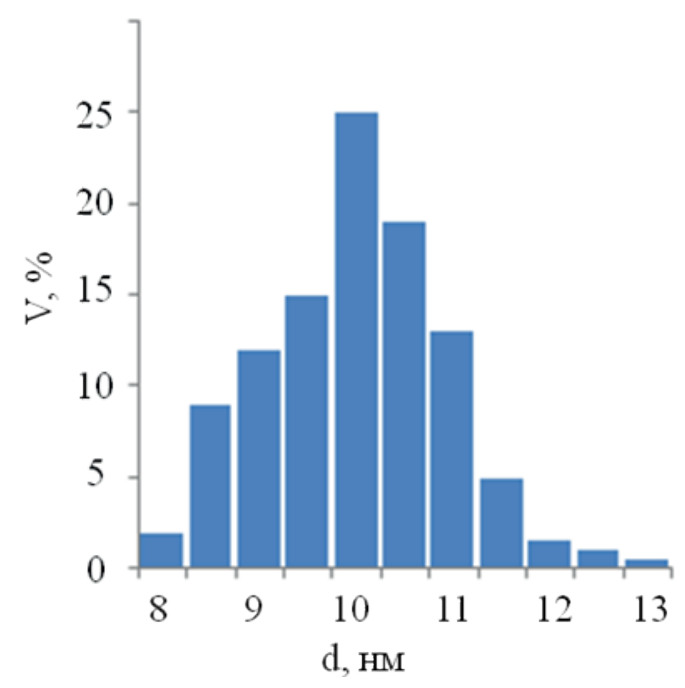

Рис. 5. Гистограмма распределения серебряных наночастич по размерам. 
распределение наночастиц по размерам яв яется Аостаточно узким.

Были изучены некоторые физические характеристики полученных наночернил. Так, вязкость синтезированных серебряных наночернил составила 17-20 сП, а поверхностное натяжение 28-30 мН/м.

Таким образом, были изучены и охарактеризованы стандартные дисперсии серебряных наночастиц и серебряные наночернила. Было уставлено, что разработанные серебряные наночернила полностью удовцетворяют требованиям Аля 2D струйной печати.

\section{1. Струйная печать серебряными наночернимами}

Струйная печать синтезированными наночернилами проводилась с использованием принтера (Fujifilm Dimatix Inc) Dimatix DMP2831, оснащенного картриджем с 16 соплами и кремниевой MEMS печатающей головкой и номинальным объемом капли кажАого до 10 пкл (рис. 6).

ОАними из основных параметров печати является объем капли чернил, формирующейся в Аюзе картриджа принтера и расстояние межАу Авумя соседними напечатанными каплями на подложке. Используемый объем капли Ао 10 пкц явцяется оптимальным, вследствие использования серебряных наночастиц с размером, преимущественно, до 12 нм. При Аанном объеме капли матеральный размер капли на поверхности подложке не превышает 20 мкм, что и определяет разрешение печати Аанным методом.

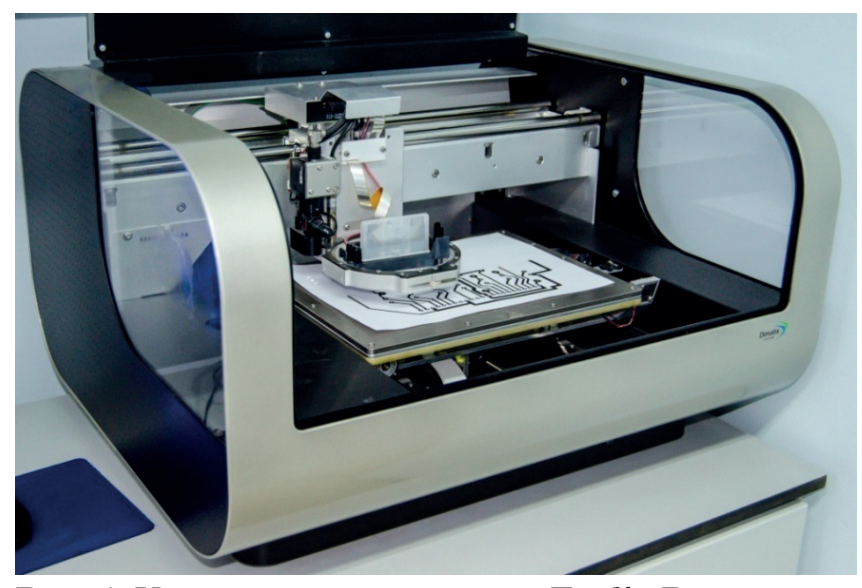

Рис. 6. Установка струйной печати - Füїіlm Dimatix-2831.

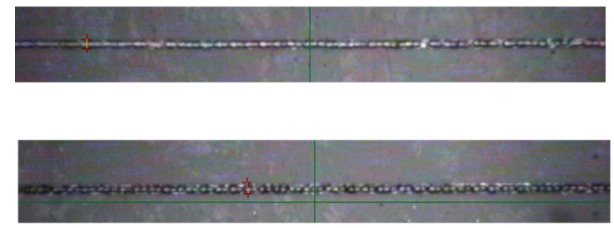
3 прохода (25 мкм)

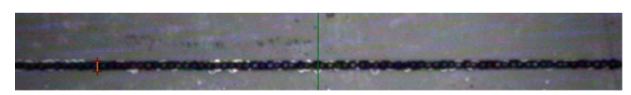

10 проходов (25 мкм)

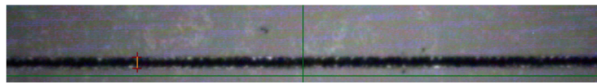

20 проходов (31 мкм)

Рис. 7. Изображение линий с различнылм количеством слоев, напечатанных серебрянныли наночернилами на полимерной пленке; изображение получено с оптического микроскопа (в скобках указана ширина минии).

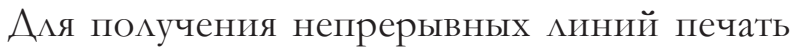
может проводиться в несколько проходов. На рис. 7 изображены минии, напечатанные серебряными наночернилами с различным количеством слоев, печать проводилась 3, 5, 10 и 20 раз. При этом ширина напечатанной Аинии увеличивалась незначительно: от 25 мкм до 31 мкм. На рис. 8 показана фотография напечатанных дорожек на гибкой полимерной пленке. Ширина самой узкой доррожки - 30 мкм.

\section{2. Обработка подможек в плазме}

Поскольку используемая печатная технология основана на струйном принципе, то одним из условий печати явцяются подходящие поверхностные свойства подложек, в частности, контактный угол смачивания (или краевой угол смачивания) поверхности подиожки. В случае гидрофобной поверхности подложки возможно стягивание напечатанной структуры в отдельные капли, что явАяется причиной нарушения целостности напечатанных структур. А^я решения задачи гидрофимизации подложек широко используется обработка подложки в плазме.

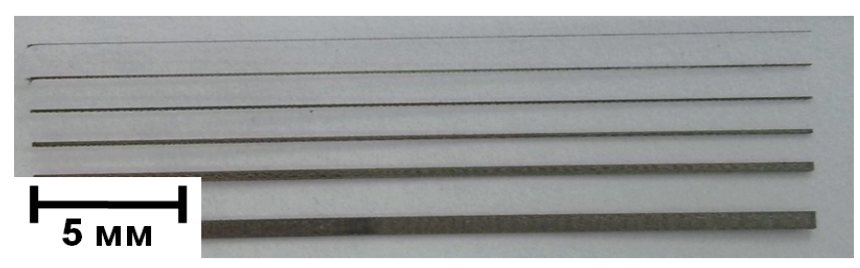

Рис. 8. Фотография напечатанных серебряных дорожек на гибкой полимерной пленке. ШІирина самой узкой дорожки - 30 мкм. 


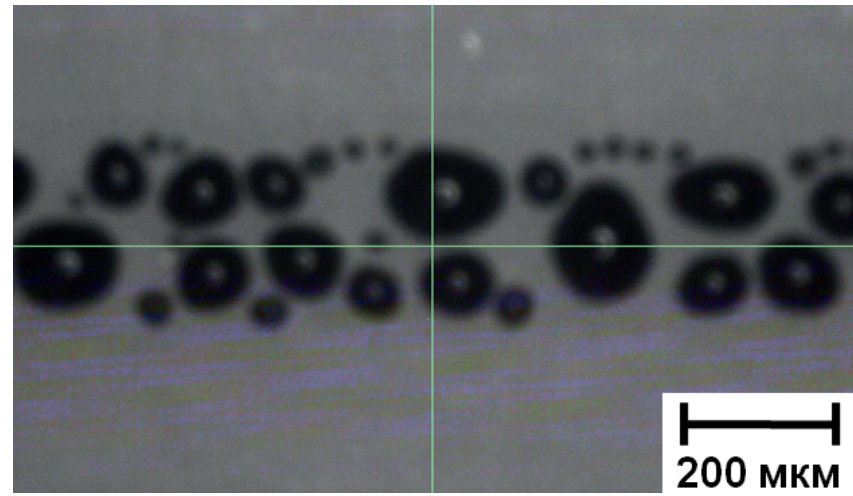

Рис. 9. Изображение напечатанной серебряными наночернилами на полиимидной пленке минии шириной 200 мкм; изображение получено методом оптический микроскопии.

Так на установке «Tantec VacuLAB» были проведены эксперименты по воздействию плазмы на поверхностные свойства керамических и полиимидных подложек. Ао возАействия плазмы на подложки, чернила на поверхности формировали изолированные Аруг от Аруга капли (рис. 9).

В случае воздействия плазмы на керамические и полиимиАные подлОжки контактный уго смачивания послеАних увеличивался, поверхностные свойства приобретали гилрофильный характер. На рис. 10 изображены напечатанные Аинии на подиожках, обработанных плазмой.

Таким образом, данная технология гидрофилизации поверхностей увеличивает Аиапазон типов подиожек, используемых в технологии струйной печати электронных компонент.

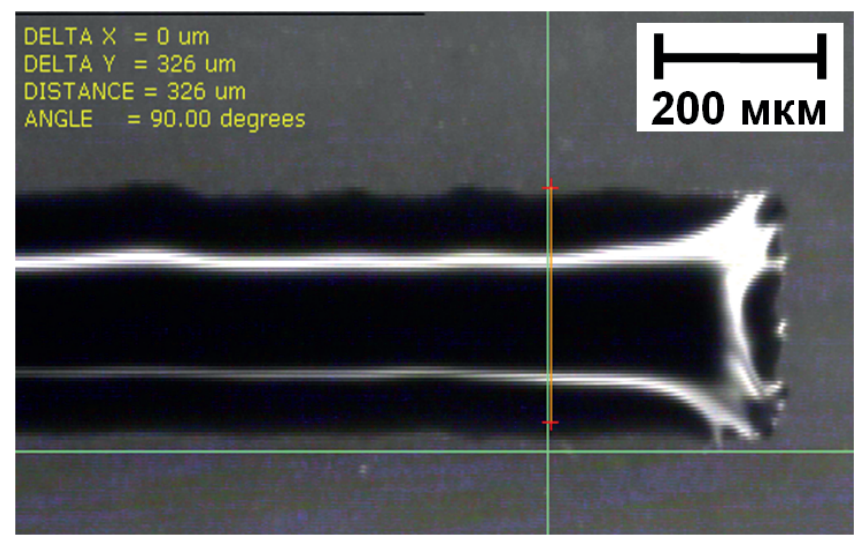

Рис. 10. Изображение напечатанной серебрянылми наночернилами на полиимидной пленке линии шириной 200 мкм; изображение получено методом оптический микроскопии.

\section{3. Термообработка}

Аля связывания отдельных серебряных наночастиц и, Аалее, формирования цельной металиической структуры необходимо проведение нагрева частиц посредством термического воздействия или оптическими импульсами высокой энергии.

На рис. 11 представлены изображения сканирующей электронной микроскопии напечатанных $\quad$ иний серебряными наночернилами при различных температурах отжига.
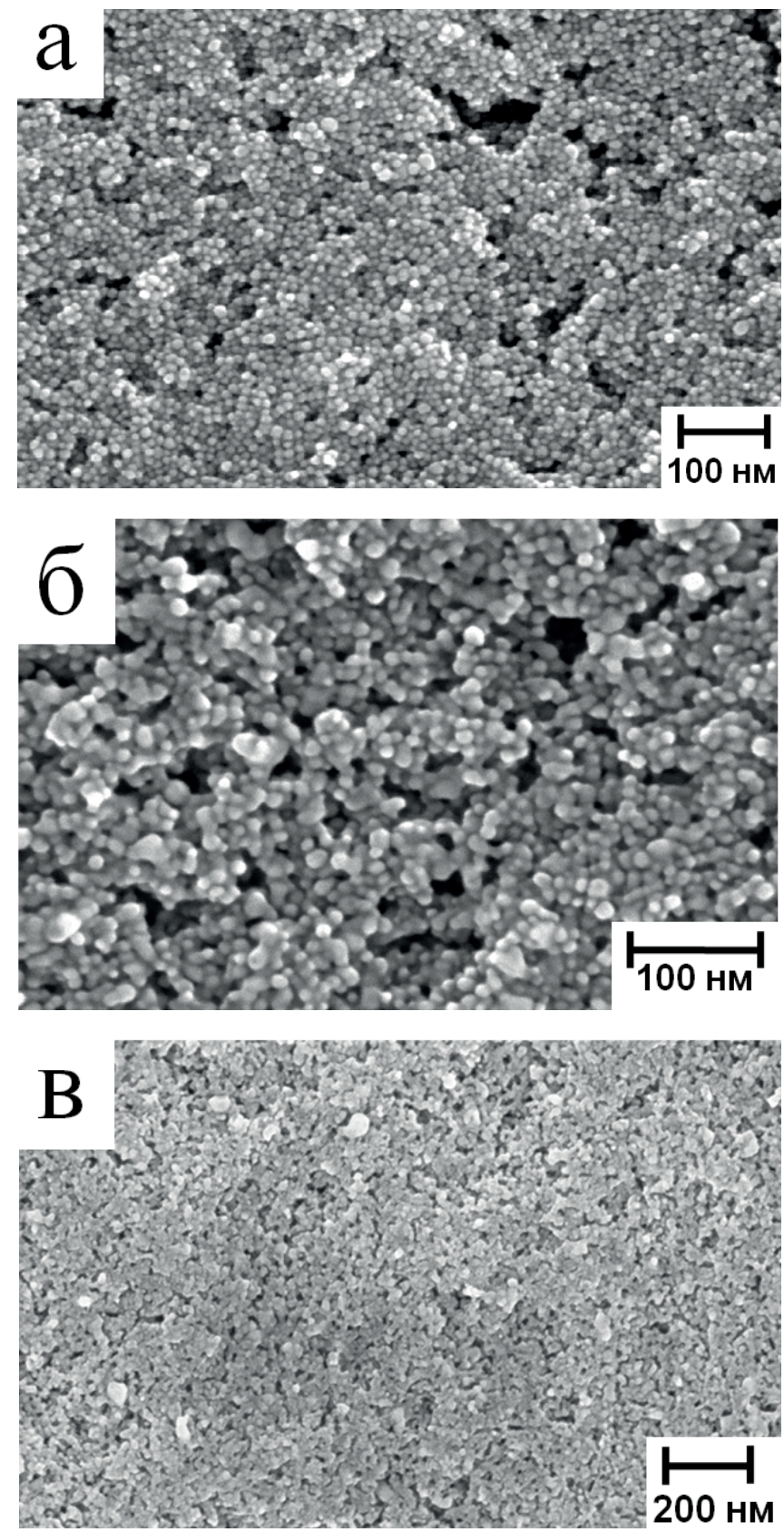

Рис. 11. СЭМ-изображения серебряных наночастич: а без термообработки; б - термообработка при 90 $\mathrm{C}$; в термообработка при $150^{\circ} \mathrm{C}$. 
Стоит упомянуть, что температура плавления массивного серебра составцяет $962^{\circ} \mathrm{C}$. Из приведенных рисунков видно, что уже при $90^{\circ} \mathrm{C}$ серебряные наночастицы начинают спекаться межАу собой, это объясняется повышенной поверхностной энергией наночастиц. Учитывая, что подобный нагрев (около $90^{\circ} \mathrm{C}$ ) не разрушает большинство полимерных пленок, Аанная технология может быть эффективно использована Аля создания металлических токопроводящих структур на гибких полимерных пленках.

Измерения удельного сопротивления напечатанных серебряными наночернилами структур производились при разАичных температурах отжига (рис. 12).

Результат: значение удельного сопротивления серебряных наночернил при температуре отжига $400^{\circ} \mathrm{C}$ состав яет $0.025 \mathrm{Oм}^{*} \mathrm{мm}^{2} / \mathrm{M}$, в то время как значение удельного сопротивления массивного серебра $0.015 \mathrm{Oм}^{*} \mathrm{mм}^{2} /$ м. Это свидетельствует о практически полном спекании массива наночастиц в единую структуру.

\section{4. Печать серебряными наночернимами токопроводящих миний на поверхности ITO}

На принтере Fujifilm Dimatix 2831 производилась печать серебряными наночернилами на кремниевой подложке, покрытой слоем ITO - оксида индия и олова, Indium Tin Oxide, соединения, содержащего 90 вес.\% $\operatorname{In}_{2} \mathrm{O}_{3}$ и 10 вес.\% $\mathrm{SnO}_{2}$, оптически прозрачного и электропроводного.

$\rho$,

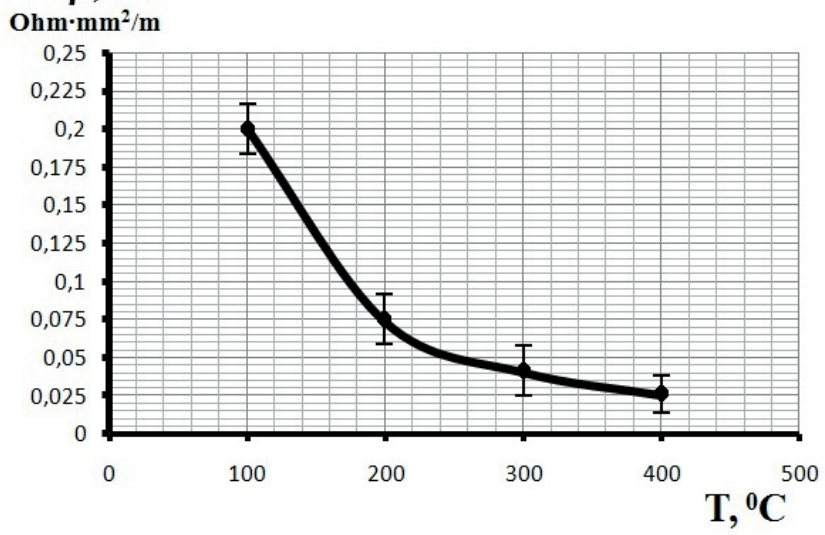

Рис. 12. График зависимости удельного сопротивления напечатанных серебрянызми наночернилами структур ири mемпературах отжига от $100^{\circ} \mathrm{C}$ до $400^{\circ} \mathrm{C}$.
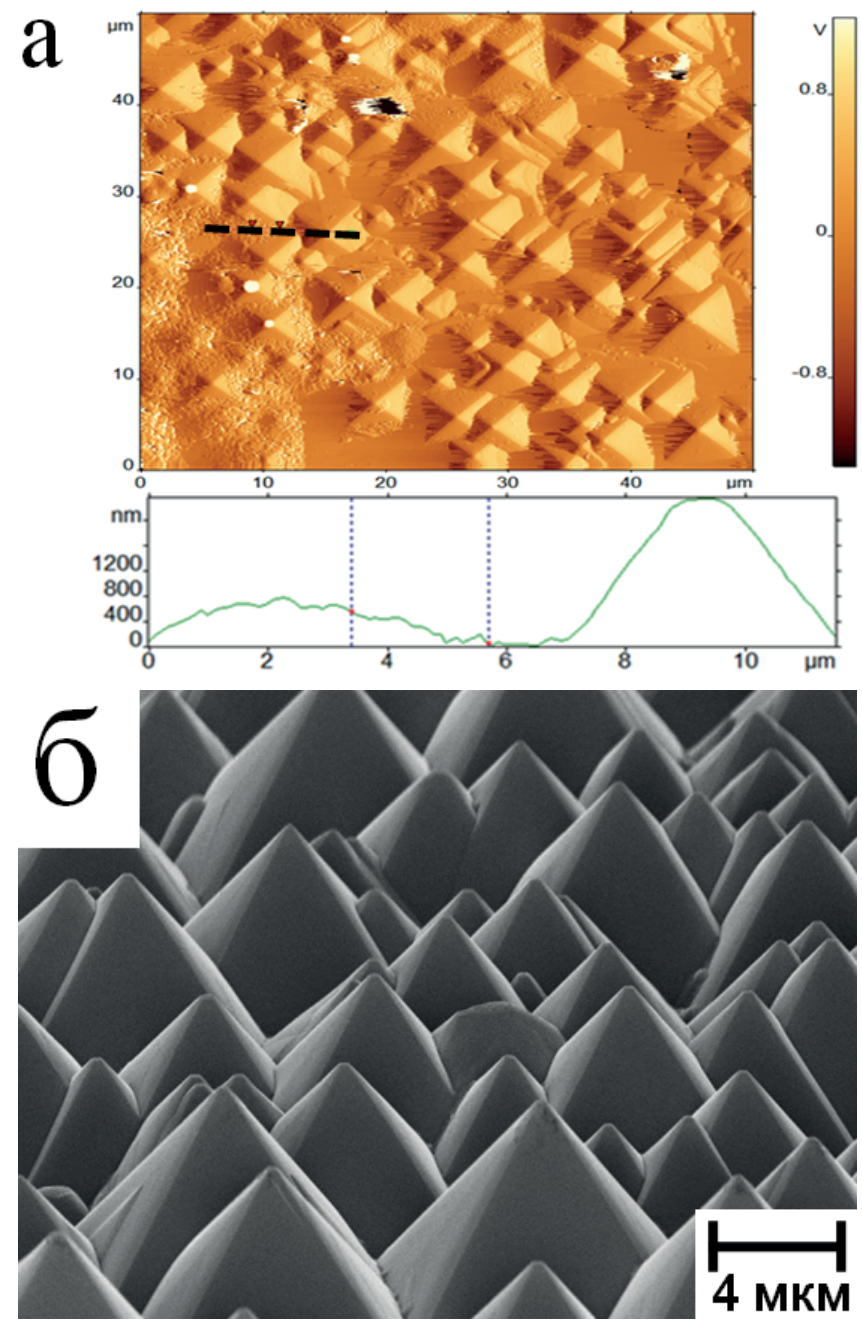

Рис. 13. Изображения поверхности ITO: а - вид сверху (получено методам $A C M$ ), б -вид сбоку (получено методам CЭM).

Исследования поверхности данных подложек, а также структуры напечатанных Аиний производилось методами сканирующей электронной микроскопии и атомно-силовой микроскопии (рис. 13 - 16).

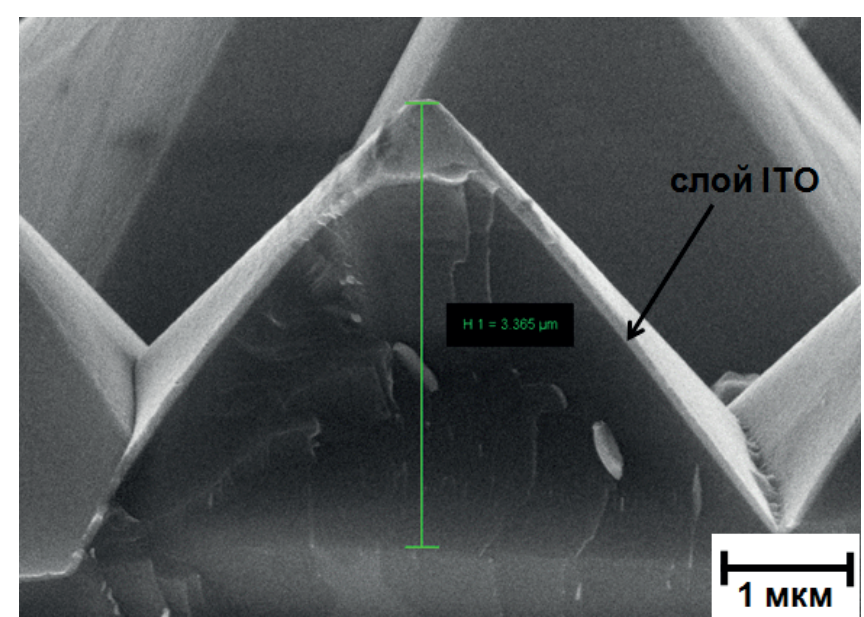

Рис. 14. СЭМ-изображение скола подложки. 

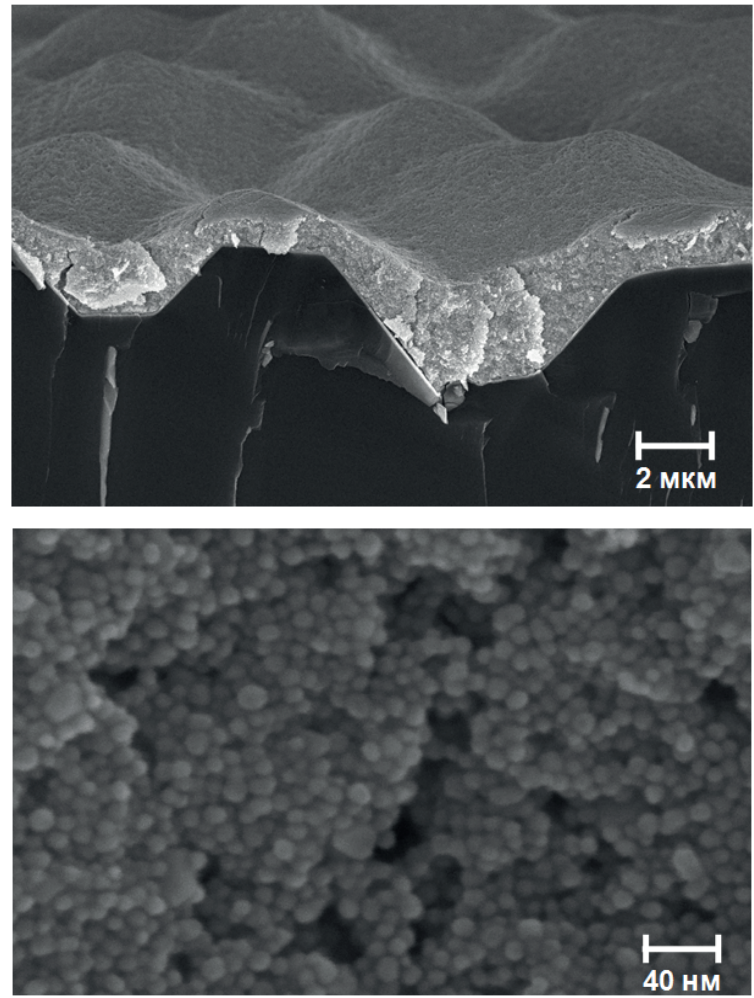

Рис. 15. Изображения напечатанных неотоженных токопроводящих элементов на поверхности IТО: сверху - вид сбоку, ниже - вид сверху, полученных методом СЭМ.

Серебряные токопроводящие Аинии были напечатаны шириной от 100 мкм до 2 мм, причем высота полученных структур не превышала 2
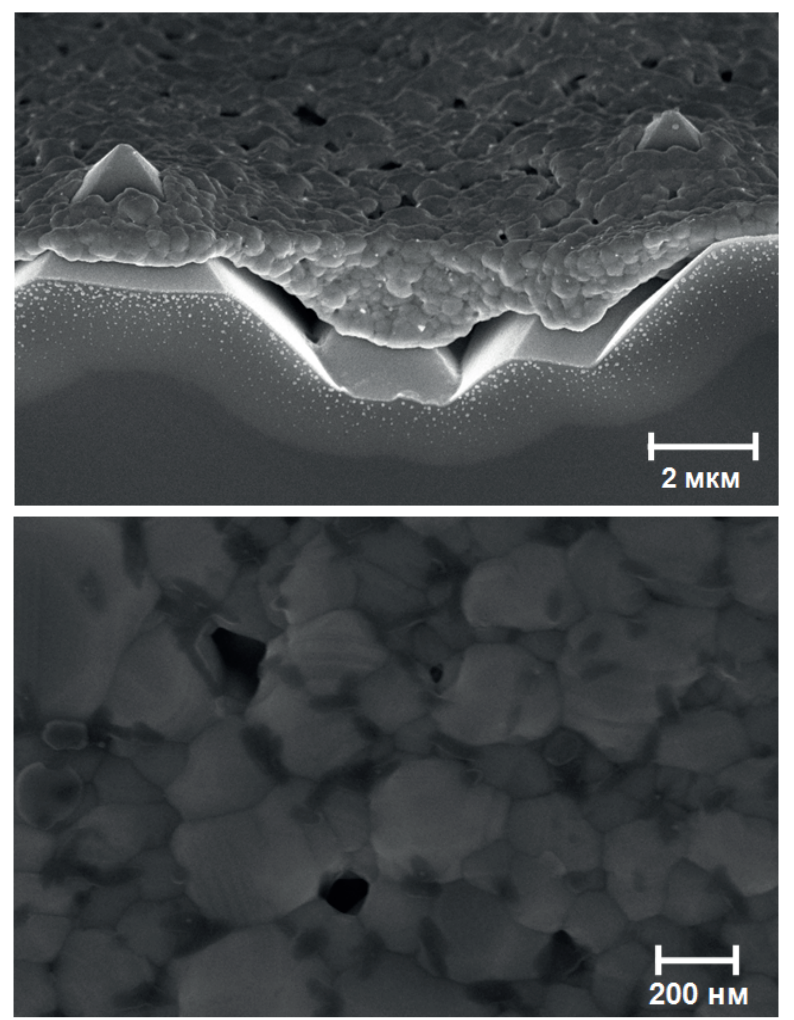

Рис. 16. Изображения напечатанных токопроводящих элементов на поверхности ITO, отоженных при температуре $120^{\circ} \mathrm{C}$ в течение 15 мин, полученных методом СЭМ: сверху - вид сбоку, ниже - вид сверху.

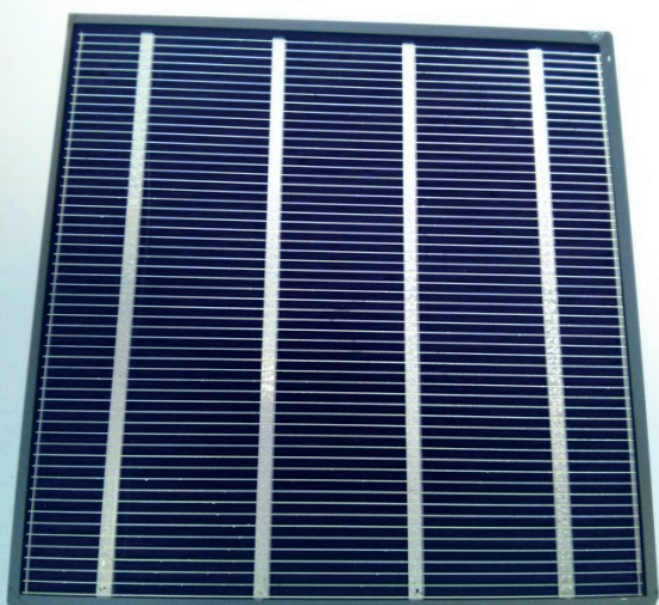

Рис. 17. Фотография напечатанных токопроводящих элементов на кремниевой подложке (размером $15 \mathrm{~cm} \times 20 \mathrm{~cm}$ ), покрытой слоем ITO.

мкм. Отжиг напечатанных миний проводился при температуре $120^{\circ} \mathrm{C}$ в течение 15 мин.

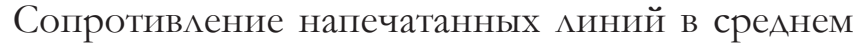
состав яяло 2 Ом/см.

Таким образом, было показано, что технология струйной печати наночернилами на основе токопроводящих наночастиц в перспективе может быть использована Аля создания Токопроводящей разводки на подложках, покрытых слоем ITO (рис. 17), в частности, на солнечных элементах.

\section{5. Печать серебряными наночернимами токопроводящих миний на поверхности кремния}

Поскольку на Аанный момент кремний широко используется в электронной промышленности, крайне важной задачей является апробация кремниевых подложек (рис. 18) в технологии

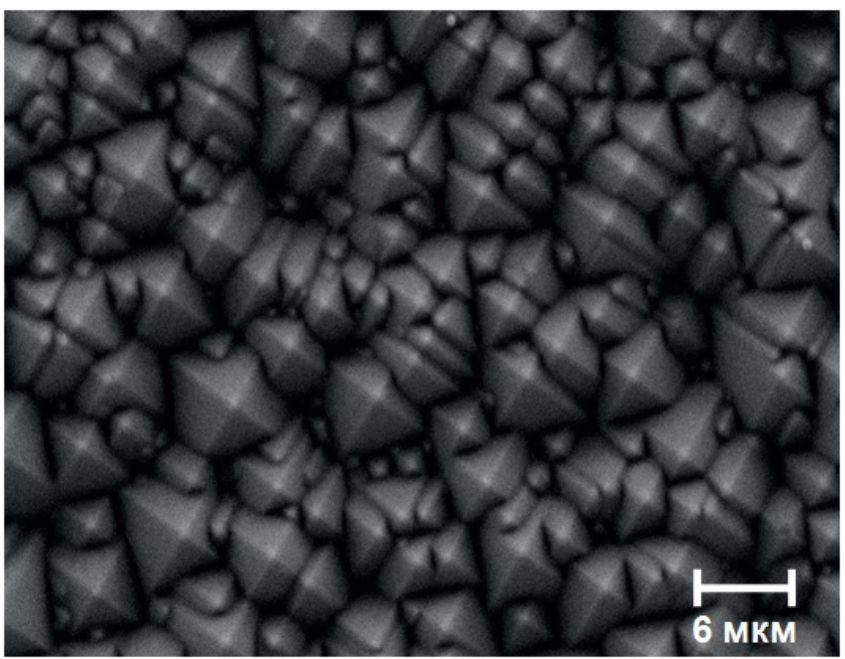

Рис. 18. СЭМ-изображение поверхности кремниевой подложки. 


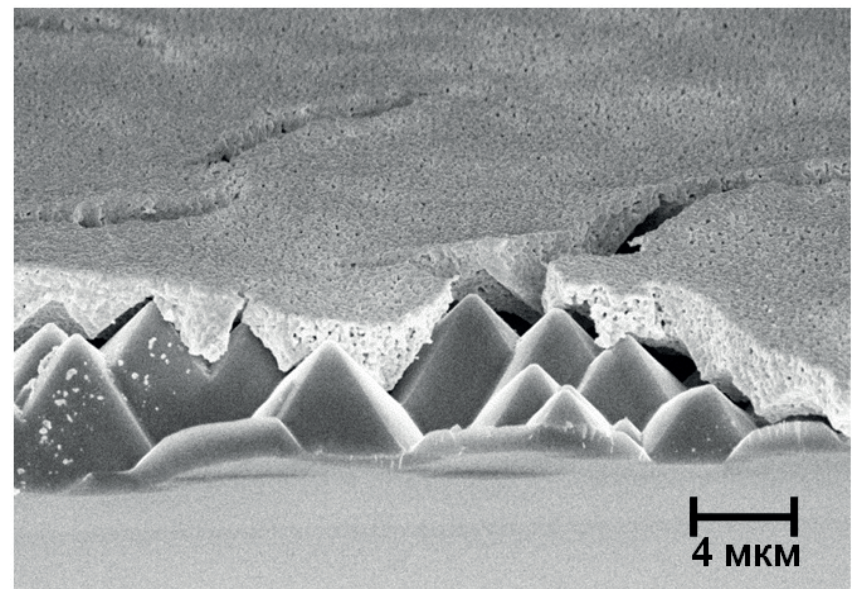

Рис. 19. СЭМ-изображение напечатанной серебряной линии на кремниевой подложке (температура отжига $195^{\circ} \mathrm{C}, 60$ мин).

струйной печати компонент электронных устройств.

Был проведен рял экспериментов по печати серебряными наночернилами с использованием установки Fujifilm Dimatix DMP - 2831 на поверхности кремниевых подиожек (рис. 19, 20).

На приведенных изображениях видно, что послетермоообработки серебряные наночастицы спекаются в еАиную электропроводящую структуру. Это подтверждает возможность применения Аанного подхода при создании электронных устройств на кремниевых поА ожках.
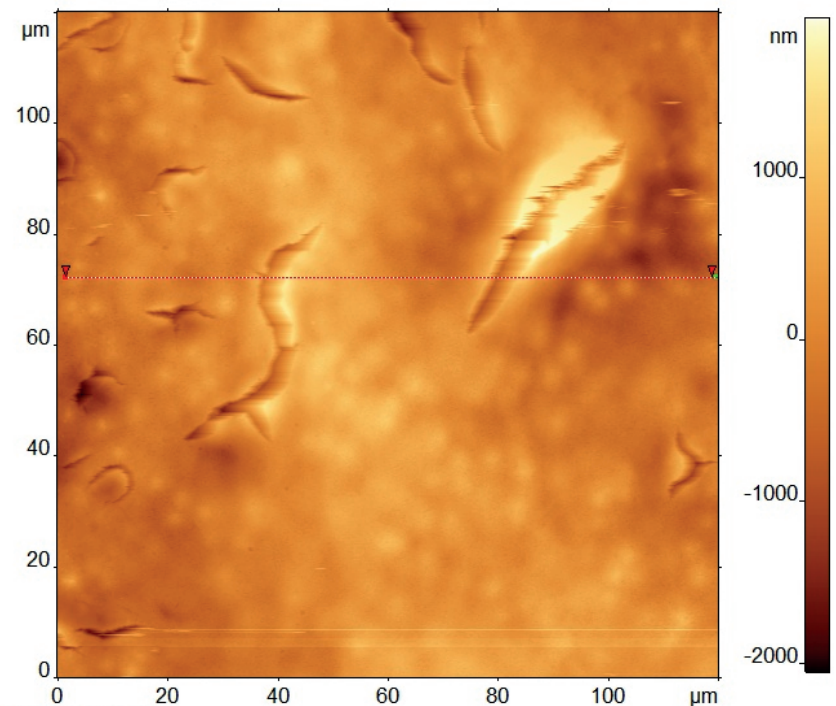

Рис. 20. АСМ-изображение топологии поверхности напечатанной серебряной минии на кремниевой подложке (отниг $195^{\circ} \mathrm{C}, 60$ мин).

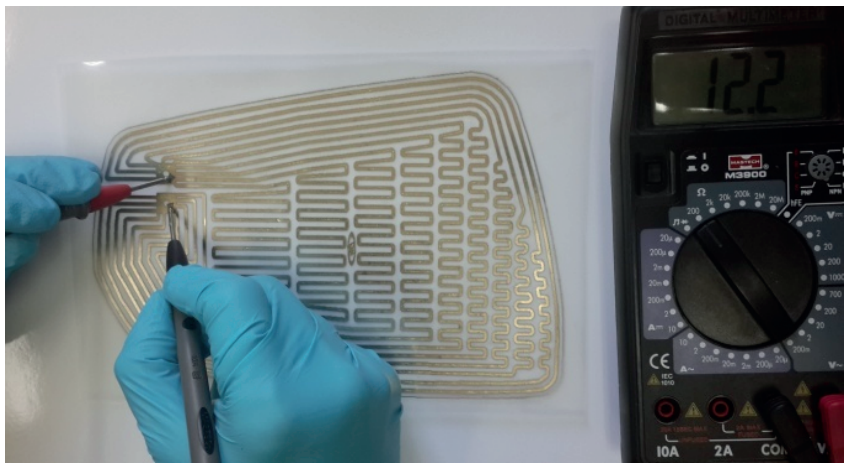

Рис. 21. Фотография образиа - нагревательного элемента, напечатанного на полимерной ленке серебряныли наночернилами.

\section{6. Печать нагревательных эмементов на полимерной пленке}

ОАним из применений струйной печати метац осодержащими наночерницами явцяется создание нагревательных элементов (рис. 21).

Проведенные эксперименты показали, что подобные элементы, напечатанные синтезированными серебряными наночернилами, имели сопротив ение - 30 Ом. С ледует отметить, что при напряжениях 12B и 18В максимальные температуры нагрева состав яли $50^{\circ} \mathrm{C}$ и $70^{\circ} \mathrm{C}$ соответственно.

\section{7. Печать токопроводящих пиатсложной} геометрии на разАичных подложках

С помощью специальноговысокопрецизионного струйного принтера Fujifilm Dimatix 2831 были напечатаны серебряные токопроводящие платы на полимерных пленках (рис. 22, 23), причем рисунок может быть мюбой геометрии с разрешением до 20 мкм. Проводимость, в свою очередь, определяется количеством нанесенного вещества и температурой отжига. Вследствие

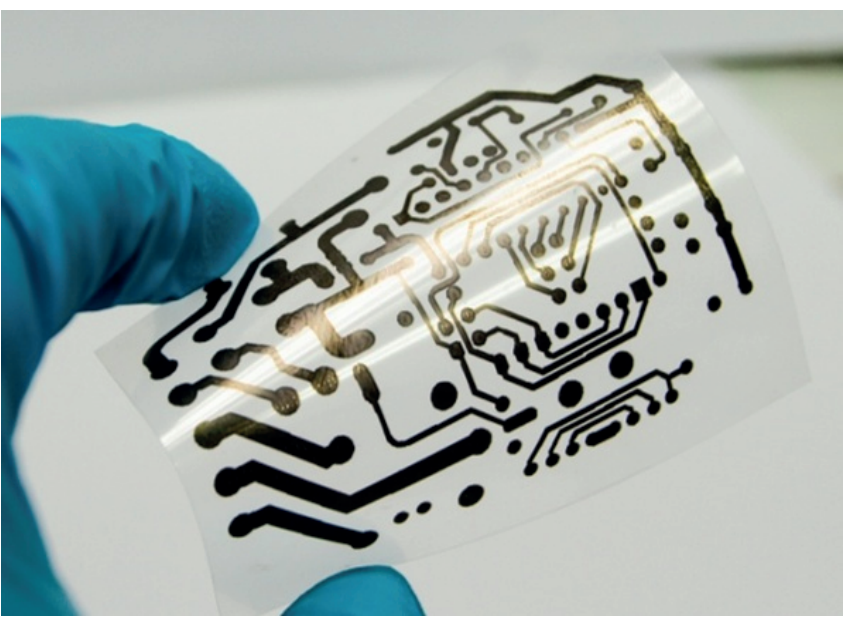

Рис. 22. Фотография токопроводящей платы, напечатанной серебряныли наночернилами на полимерной пленке. 


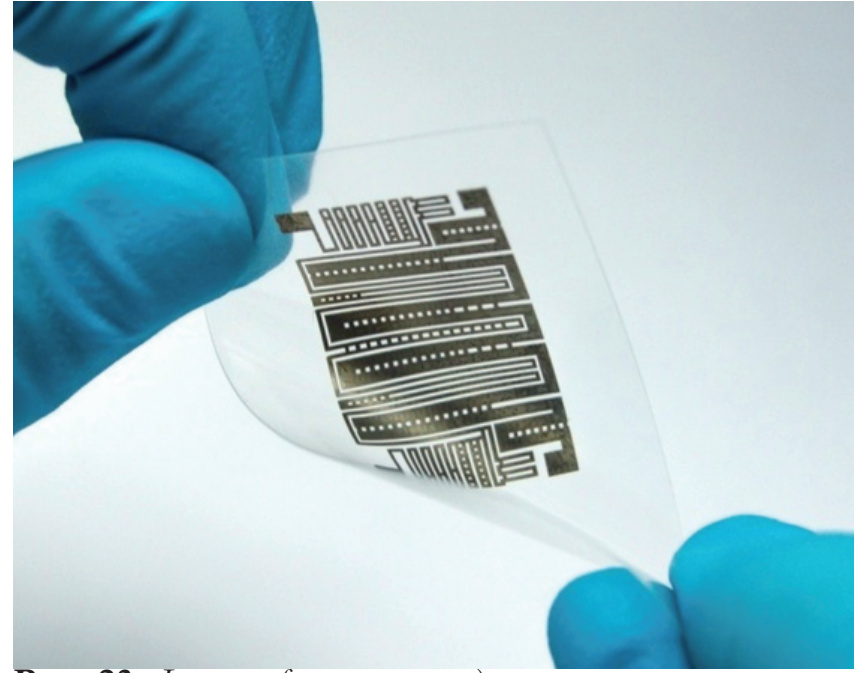

Рис. 23. Фотография токопроводящей платы напечатанной серебряными наночернилами на полимерной пленке.

плавления гибких полимерных пленок при температуре $200^{\circ} \mathrm{C}$, печать токопроводящих элементов на полимерных подложках возможна только токопроводящими наночастицами, поскольку температура плавления последних гораздо ниже массивных аналогов. Так температура плавления массивного серебра $962^{\circ} \mathrm{C}$, а серебряные наночастицы начинают сплавляться уже при $90^{\circ} \mathrm{C}$.

Также были напечатаны модельные образцы RFID-антенны (радиочастотная илентификация, Radio Frequency IDentification) и обклалок аккумулятора (рис. 24).

В качестве поАложки также использовались: полиимидная пленка (рис. 25, 26), керамика, глянцевая бумага, стекло.

Поверхность стекла и полиимидной пленки обрабатывались растворителями: изопропиловый спирт, ацетон, хлороформ и

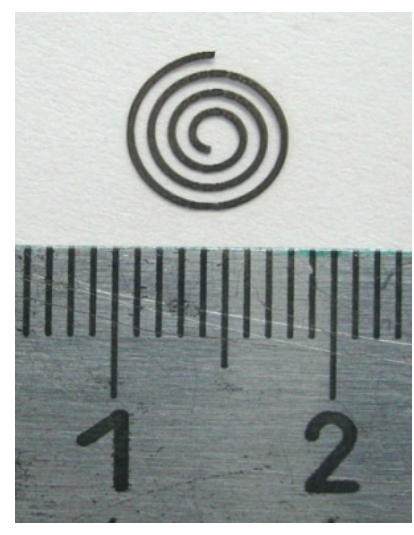

$a$

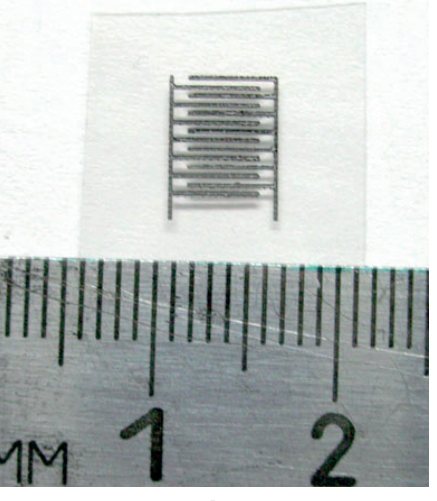

$b$
Рис. 24. Фотографии RFID антенныг (а) и токопроводямих обкладок аккумулятора (b), напечатанныле серебряными наночернилами на полимерной пленке.

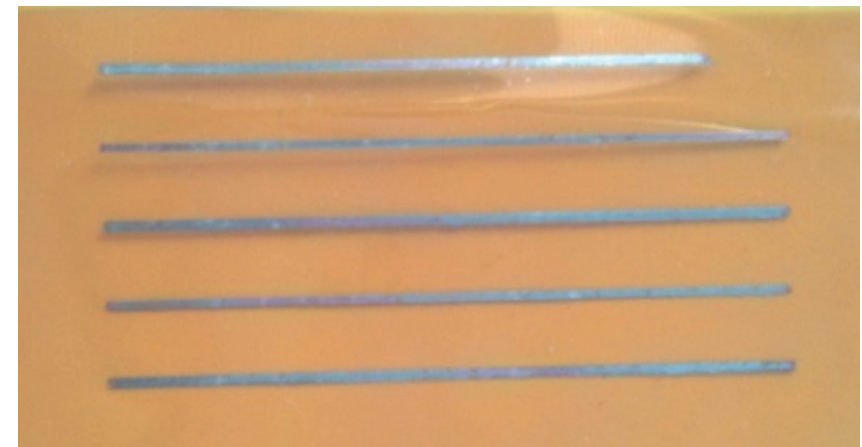

Рис. 25. Фотография токопроводящих дорожек, напечатанных серебряныли наночернилами на полиимидной пленке.

поверхностно-активными веществами. Таким образом, поверхность подложек обезжиривацась и принимала гилрофильные свойства.

В настоящее время керамика широко используется в электронной промышленности, в основном, в качестве жесткого носителя элементов электронных устройств. Этим был обоснован выбор керамической подложки. Поскольку керамика имеет пористую структуру, то близлежащие токопроводящие элементы закорачивались в структурных порах керамики. Аанная проблема была решена подачей необходимого Аһя сжигания подобных «мостиков» напряжения. К полученным образцам получилось припаяться, что свидетельствует о возможности практического внедрения в существующие технологические циклы по производству элементов электронных устройств на керамике.

ГАянцевая фотобумага на данный момент не используется в электронной промышленности, однако Аанная подцожка имеет одно несомненное преимущество: за счет своей пористой структуры и глянцевого слоя на поверхности, растворитель

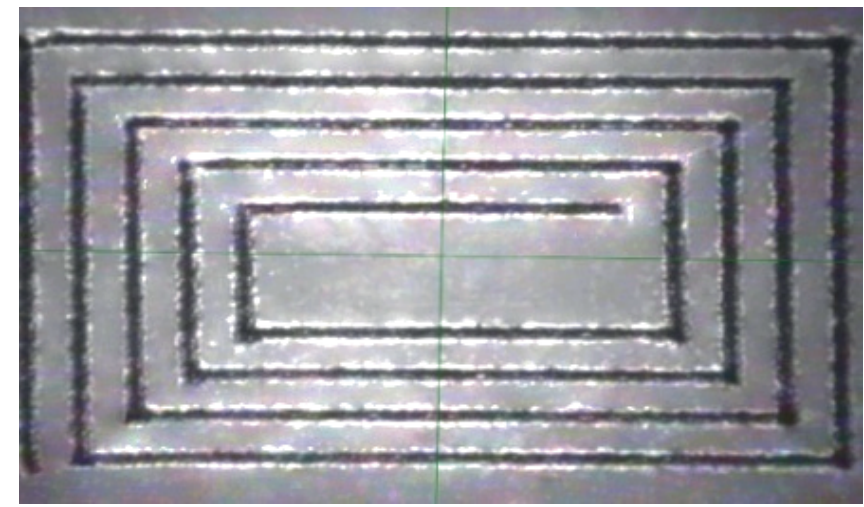

Рис. 26. Изображение, полученное методом оптический микроскопии, RFID антенны, напечатанной серебрянылми наночернилами на полиимидной пленке. 
серебряных наночернил моментально впитывается в структуру, а наночастицы серебра остаются на поверхности. Таким образом, появ яется возможность без Аополнительной постпечатной обработки рисовать и печатать токопроводящие элементы непосредственно на бумаге.

\section{8. Печать серебряными наночернимами на текстимьных издемиях}

Была произведена печать серебряными наночернилами на текстильных изделиях (рис. 27). Наличие электронной проводимости у конечных образцов было обусловлено

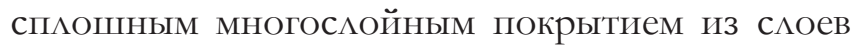
отожженных металиических наночастиц на поверхности ткани. Стабильность параметров образца к изгибу и к взаимодействию с водой - неудовлетворительная. Причина нарушение целостности слоя из отожженных серебряных наночастиц. Низкая степень алгезии, предположительно, связана с большим количеством слоев наночастиц.

\section{4. ЗАКАЮЧЕНИЕ}

Компанией ООО «АкКо Ааб» разработана методика получения серебряных наночернил. C точки зрения коциоиАной химии, разработанные наночернила представляют собой высококонцентрированные Аисперсии серебряных наночастиц. Согласно Аанным просвечивающей электронной микроскопии и сканирующей электронной микроскопии, наночастицы серебра в наночернилах имеют близкую к сферической форму. Кроме того, серебряные наночастицы характеризуются

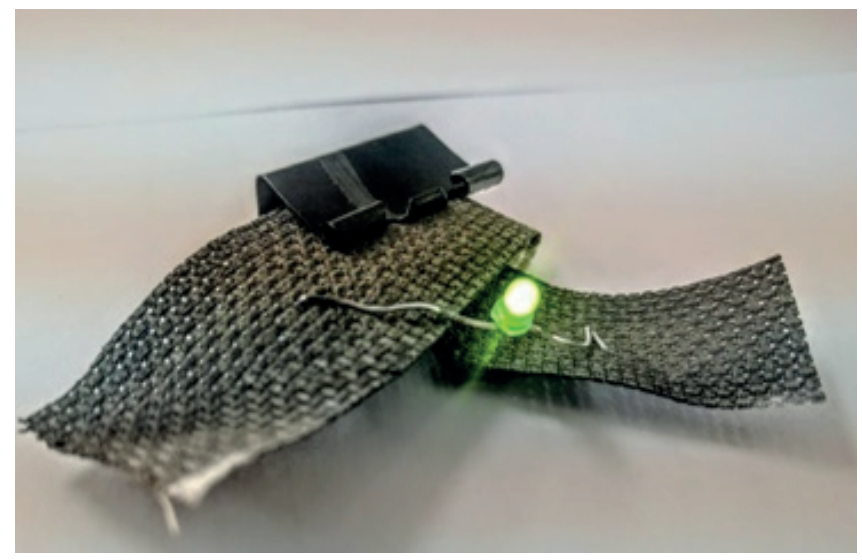

Рис. 27. Печать серебрянылминаночернилами натекстильныгх изделиях.
Аостаточно узким распределением частиц по размерам, от 8 до 12 нм.

Серебряные наночернила адаптированы Аля печати на высокотехнологичном принтере Dimatix Material Printer DMP-2831. Отработана печать разАичных токопроводящих структур на подложках различной природы: керамика, стекло, слой ITO, гибкие полимерные пленки, текстильные изАелия. Показано, что качество печати зависит от комплекса различных параметров: природы субстрата, аАгезии наночернил к поверхности подложки, температуры печати, количества проходов печати.

Следует отметить, что печать возможна практически на ОАнако Аля успешной печати предварительно необходимо обработать поверхность, на которой будет проводиться печать, физическим (в частности, обработкой в плазме) или химическим способом (обработка поверхностноактивными веществами, спиртами и т.А.) А^я того, чтобы поверхность слелать смачиваемой А^я наночерних и пригодной к печати.

Важной характеристикой разработанных наночернил является Аостаточно низкая температура спекания серебряных наночастиц. Так, температура начаца спекания серебряных наночастиц в проводящий слой значительно ниже температуры плавления своего компактного аналога и составцяет примерно $100^{\circ} \mathrm{C}$.

Серебряные наночернила, разработанные компанией ООО «АкКо Ааб» прошли тестовые испытания в компании Fujifilm Dimatix Inc. в Калифорнии (США), и получили высокие оценки. Серебряные наночернила являются коммерческим продуктом и постав яяются конечным заказчикам на территории России и за рубежом.

Полученные результаты показывают перспективу использования технологииструйной печати метал^осодержащими наночернилами Аля производства электронных устройств, в том числе и на гибких подцожках.

Работа бълла частично поддержана грантом У.М.Н.И.К. Фонда содействия инновачиям (договора №2173ГУ1 / 2014; № 7379 ГУ2/ 2015). 


\section{МИТЕРАТУРА}

1. Kamyshny A, Steinke J, Magdassi S. Metal-based Inkjet Inks for Printed Electronics. The Open Applied Physics Journal, 2011, 4:19-36.

2. Finn DJ, Lotya M, Coleman JN. Inkjet Printing of Silver Nanowire Networks. ACS Appl. Mater. Interfaces, 2015, 7(17):9254-9261.

3. Torrisi F, Hasan T, Wu W, Sun Z, Lombardo A, Kulmala TS, Hsieh G-W, Jung SJ, Bonaccorso F, Paul PJ, Chu DP, Ferrari AC. Ink-Jet Printed Graphene Electronics. ACS Nano, 2012, 6(4):2992-3006.

4. Tobjork D, Osterbacka R. Paper electronics. Advanced materials, 2011, 23:1935-1961.

5. Gaikwad AM, Whiting GL, Steingart DA, Arias AC. Highly Flexible, Printed Alkaline Batteries Based on Mesh-Embedded Electrodes. Advanced materials, 2011, 23:3251-3255.

6. Hildera M, Winther-Jensenb B, Clarka NB. Paper-based, printed zinc-air battery. Journal of Power Sources, 2009, 194:1135-1141.

7. Park J, Moon J, Shin H, Wang D, Park M. Directwrite fabrication of colloidal photonic crystal microarrays by ink-jet printing. Journal of Colloid and Interface Science, 2006, 298:713-719.

8. Jillek W, Yung WKC. Embedded components in printed circuit boards: a processing technology review. International Journal of Advanced Manufacturing Technology, 2005, 25:350-360.

\section{Ткачев Сергей Викторович}

א.X.H., C.H.C.

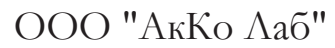

65/1, ум. Гицяровского, 129110 Москва, Россия

ИОНХ им. Н.С. Курнакова РАН

31, Аенинский пр., 119991 Москва, Россия tkachev_svmsu@mail.ru

\section{Ким Виталий ПавАович}

к.ф.-м.н., с.н.с.

ООО "АкКо Ааб"

65/1, ум. Гицяровского, 129110 Москва, Россия vp.kim@physics.msu.ru

Кушнир А^ексей Евгеньевич

научный сотрудник

ООО "АкКо Ааб"

65/1, ум. Гицяровского, 129110 Москва, Россия kushnir.a.e@gmail.com

Корнимов Аенис Юрьевич

א.m.H.

ООО "АкКо Ааб"

65/1, ум. Гицяровского, 129110 Москва, Россия kornilovdenis@rambler.ru

Губин Сергей Павмович

д.х.н., проф., действительный илен $\mathrm{PAEH}$

ООО "АкКо Ааб"

65/1, ум. Гицяровского, 129110 Москва, Россия ИОНХ им. Н.С. Курнакова РАН

31, Аенинский пр., 119991 Москва, Россия

gubin@igic.ras.ru 


\title{
THE DISPERSIONS OF NANOPARTICLES IN WATER-ORGANIC SOLVENTS AS THE BASIS FOR THE SILVER NANO-INK FOR INK- JET PRINTING
}

\author{
Sergey V. Tkachev, Sergey P. Gubin
}

"AkKo Lab" LLC, http://akkolab.ru.en

129110 Moscow, Russian Federation

Kurnakov Institute of General and Inorganic Chemistry, Russian Academy of Sciences, http:/ /www.igic.ras.ru 117991 Moscow, Russian Federation

tkachev_svmsu@mail.ru, gubin@igic.ras.ru

Vitalii P. Kim, Alexey E. Kushnir, Denis Yu. Kornilov

"AkKo Lab" LLC, http://akkolab.ru.en

vp.kim@physics.msu.ru, kushnir.a.e@gmail.com, kornilovdenis@rambler.ru

Abstract. The work is aimed to solve the problem of developing functional silver nano-ink applied in ink-jet technology in printed flexible electronics, as well as to demonstrate printing results and their discussion. The development of functional compounds for printing is a fundamentally new approach to the production of flexible electronic devices for the military and civil industry. As a part of the work special attention is paid to the preparation of aqueous and organic dispersions of silver nanoparticles, the study of the various factors which affect the size and characteristics of the nanoparticles, methods of concentrating the standard dispersions to obtain nano-ink, printing the conductive structures by synthesized nano-ink and research of the printed elements' properties. These results give an opportunity to develop silver nano-ink and adapt it for printing on various substrates (including flexible polymeric ones) by specialized equipment.

Keywords: silver nano-ink, aqueous dispersions, ink-jet printing, conductive structures, polymeric substrate, flexible printed electronics

UDC 546.57, 621.3.049.7

Bibliography - 8 references

Received 5.12.2016

RENSIT, 2016, 8(2):171-184

DOI: $10.17725 /$ rensit.2016.08.171 


\title{
ПРИМЕНЕНИЕ ТЕХНОАОГИЙ ПАРАААЕАЬНОГО ПРОГРАММИРОВАНИЯ ААЯ МОАЕАИРОВАНИЯ СЕЙСМИЧЕСКИХ ВОАН СЕТОЧНО-ХАРАКТЕРИСТИЧЕСКИМ METOAOM
}

\author{
${ }^{1}$ Иванов А.М., ${ }^{1}$ Хохмов Н.И., ${ }^{1,2}$ Петров И.Б. \\ ${ }^{1}$ Московский физико-технический институт, http:/ / mipt.ru \\ г. Аолгопрудный, 141701 Московская область, Российская Федерация \\ ${ }^{2}$ Научно-исследовательский институт системных исследований, Российская академия наук, https:/ / www.niisi.ru \\ 117218 Москва, Российская Федерация \\ Поступила в редакиию 25.11.2016
}

В работе рассматривается решение гиперболической системы уравнений сеточнохарактеристическим методом применительно к задаче моделирования распространения сейсмических волн в твердых деформируемых телах. Напримереэтой задачи Аемонстрируется применение технологий параммельного программирования Амя систем с общей памятью с использованием технологий OpenMP и POSIX Threads. Аیя достижения максимальной производительности использовались векторные инструкции SSE и AVX на центральных процессорах. Также было произведено распарамлеливание Аля графических процессоров при помощи технологий CUDA и OpenCL. На графических процессорах было рассмотрено распаралмеливание на нескольких GPU, в том числе и с использованием технологии NVIDIA GPUDirect, позвомяющей графическим процессорам осуществлять обмены данными напрямую без участия центрального процессора. Показаны достигнутое ускорение распаралмеливания и процент от теоретически возможной производительности. В работе описываются произведенные оптимизации, которые позволили достигнуть полученных результатов ускорения.

Ключевые слова: математическое моделирование, парамлельное программирование, сеточнохарактеристический метоА, общая память, сейсмика, векторизация, GPU, CUDA, OpenCL

УАК 519.633

\section{СОДЕРЖАНИЕ}

1. ВВЕАЕНИЕ (185)

2. МАТЕМАТИЧЕСКАЯ МОАЕАЬ (186)

3. ЧИСАЕННЫЙ МЕТОА (186)

4. ПоСТАНОВКА ЗАААЧИ (187)

5. УСАОВИЯ ТЕСТИРОВАНИЯ РАСПАРАААЕАИВАНИЯ (187)

6. ПРОЦЕСС ОПТИМИЗАЦИИ (188)

7. ПАРАААЕАЬНАЯ ВЕРСИЯ (189)

8. ОПТИМИЗАЦИЯ ААГОРИТМА НА ГРАФИЧЕСКИХ ПРОЦЕССОРАХ (189)

8.1. Перенос реализации с CPU на GPU cuda1 (190)

8.2. Структурамассивовипоследовательное обращение к памяти - cuda2 (191)

8.3. Параметры вызова kernel'a - cuda3 (191)

8.4. Размеры блоков - cuda4 (192)

8.5. Использование opencl1 (192)

9. НЕСКОАЬКО ГРАФИЧЕСКИХ ПРОЦЕССОРОВ (192)

10. ЗАКАЮЧЕНИЕ (193)

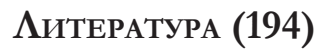

\section{1. ВВЕАЕНИЕ}

Задача распространения волн в Аинейноупругой среде представляет интерес в сейсмологии и в разведочной геофизике. С ростом производительности современных вычислительных систем и возможности параллельного выполнения программного кода, появилась возможность проводить компьютерное моделирование сейсмических волн с большой точностью. Возник вопрос, как эффективно использовать доступные вычислительные ресурсы.

ОАно из решений этого вопроса использование технологий параляельного программирования Аля систем с общей памятью. В статье [1] рассматривается задача распаралиеливания моделирования эффектов, происходящих в грунте в ходе землетрясения, с использованием технологии 
OpenMP. Применительно к Аругим задачам математического моделирования, с помощью технологии ОpenMP в работе [2] распаралмеливается конечноэлементный метоА на неструктурированных сетках.

Аругой подход - распаралмеливание на современных графических процессорах. Этому посвящено большое число работ. Например, в статье [3] рассматривается распаралмеливание конечно-разностного метода на GPU c использованием технологии CUDA [4]. Есть работы $[5,6]$ в которых решаются задачи обратной миграции на кластере из графических процессоров.

И, наконец, третий подход распаралмеливание в системах с распределенной памятью. В таких системах также могут использоваться как центральные процессоры, так и графические. В [7] распарамлелен конечно-разностный метоА моделирования вязко-упроугой среды с использованием технологии MPI [8], а в работе [9] - метоА спектральных элементов Аля моделирования распространения волн в астероиле. Кроме того, в работе [10] сравнивается эффективность распараляеливания на GPU с использоавнием CPU кластеров. Исследование [11] Аемонстрирует использование гибридной системы OpenMP + MPI Аля моделирования сейсмики конечноразностным методом.

Существуют также и Аругие подходы, подробное рассмотрение которых остается за рамками Аанной статьи. Например, использование FPGA [12] и ASIC [13].

В Аанной работе рассматривается решение гиперболической систем уравнений, которая описывает поведение во нн в твердых упругих телах. А^я нахождения решения этой системы применяется сеточно характеристический метод [14-16]. Вычисления производятся по явной схеме, поскольку в таком случае программная реализация хорошо подцается распаралмеливанию. Решение задачи распаралмелено в системах с общей памятью с помощью технологий OpenMP, POSIX Threads [17] и на графических процессорах с использованием CUDA, OpenCL [18].

\section{2. МАТЕМАТИЧЕСКАЯ МОАЕАЬ}

Аля описания поведения среды использовалась модель идеального изотропного Аинейноупругого материала. Приведённая ниже система Аифференциальных уравнений в частных производных описывает состояние элементарного объёма упругого материала в приближении малых Аеформаций Аля Авумерного случая:

$\rho \frac{\partial v_{x}}{\partial t}=\frac{\partial \sigma_{x x}}{\partial x}+\frac{\partial \sigma_{x y}}{\partial y}, \rho \frac{\partial v_{y}}{\partial t}=\frac{\partial \sigma_{x y}}{\partial x}+\frac{\partial \sigma_{y y}}{\partial y}$,

$\frac{\partial \sigma_{x x}}{\partial t}=(\lambda+2 \mu) \frac{\partial v_{x}}{\partial x}+\lambda \frac{\partial v_{y}}{\partial y}$,

$\frac{\partial \sigma_{y y}}{\partial t}=\lambda \frac{\partial v_{x}}{\partial x}+(\lambda+2 \mu) \frac{\partial v_{y}}{\partial y}$,

$\frac{\partial \sigma_{x y}}{\partial t}=\mu\left(\frac{\partial v_{x}}{\partial x}+\frac{\partial v_{y}}{\partial y}\right)$

гАе $\varrho-$ плотность среды, $\lambda, \mu$ - параметры

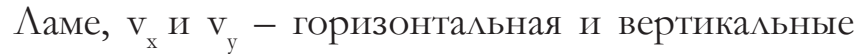
составляющие скорости частиц среды, $\sigma_{x x}, \sigma_{y y}, \sigma_{x y}$ - компоненты тензора напряжения.

Аанную систему можно переписать в матричной форме:

$\frac{\partial u_{p}}{\partial t}+A_{p q} \frac{\partial u_{q}}{\partial x}+B_{p q} \frac{\partial u_{q}}{\partial y}=0$,

гАе $\mathbf{u}$ - вектор из 5 независимых переменных $\mathbf{u}$ $=\left(\sigma_{\mathrm{xx}}, \sigma_{\mathrm{yy}}, \sigma_{\mathrm{xy}}, \mathrm{v}_{\mathrm{x}}, \mathrm{v}_{\mathrm{y}}\right)^{\mathrm{T}}$. Явный вид матриц $\mathrm{A}_{\mathrm{pq}}$ и $\mathrm{B}_{\mathrm{pq}}$ преАставлен в [19]. 3Аесь и Аалее подразумевается суммирование по повторяющимся индексам. Собственные значения матриц $\mathrm{A}_{\mathrm{pq}}$ и $\mathrm{B}_{\mathrm{pq}}$ таковы: $\mathrm{s}_{1}=-\mathrm{c}_{\mathrm{p}}, \mathrm{s}_{2}=-\mathrm{c}_{\mathrm{s}}, \mathrm{s}_{3}=0, \mathrm{~s}_{4}=\mathrm{c}_{\mathrm{s}}, \mathrm{s}_{5}=\mathrm{c}_{\mathrm{p}}$, гАe $\mathrm{c}_{\mathrm{p}}$ и $\mathrm{c}_{\mathrm{s}}$ - скорости распространения продольных и поперечных волн в среде.

\section{3. ЧИСАЕННЫЙ МЕТОА}

Применяя покоординатное расщепление, можно свести задачу построения разностной схемы А^я системы уравнений (1), к задаче построения разностной схемы Аля системы виАа:

$\frac{\partial u_{p}}{\partial t}+A_{p q} \frac{\partial u_{q}}{\partial x}=0$

$\Lambda \wedge я$ гиперболической системы уравнений (2) матрицу $\mathbf{A}$ можно представить в виде $\mathbf{A}=\mathbf{R} \mathbf{\Lambda} \mathbf{R}^{-1}$, гАе $\boldsymbol{\Lambda}$ - Аиагональная матрица, элементы которой - собственные значения матрицы $\mathbf{A}$, а $\mathbf{R}$ - матрица, состоящая из правых собственных 
векторов матрицы А. Введём новые переменные: $\mathbf{w}=\mathbf{R}^{-1} \mathbf{u}$ (так называемые инварианты Римана). Тогда система уравнений (2) сведётся к системе из 5 независимых скацярных уравнений переноса.

Приведем схему третьего порядка точности Аля численного решения одномерного Аинейного уравнения переноса $u_{\mathrm{t}}+a u_{\mathrm{x}}=0, a>0, \sigma=a \tau / h$, $\tau$ - шаг по времени, $h-$ шаг по координате:

$$
\begin{aligned}
& u_{m}^{n+1}=u_{m}^{n}+\sigma\left(\Delta_{0}+\Delta_{2}\right) / 2+\sigma^{2}\left(\Delta_{0}-\Delta_{2}\right) / 2+ \\
& +\frac{\sigma\left(\sigma^{2}-1\right)}{6}\left(\Delta_{1}-2 \Delta_{0}+\Delta_{2}\right), \\
& \Delta_{0}=u_{m-1}^{n}-u_{m}^{n}, \\
& \Delta_{1}=u_{m-2}^{n}-u_{m-1}^{n}, \\
& \Delta_{2}=u_{m}^{n}-u_{m+1}^{n} .
\end{aligned}
$$

Схема (3) устойчива Аля чисел Куранта, не превышающих единицу. Используется сеточнохарактеристический критерий монотонности, опирающийся на характеристическое свойство точного решения:

$$
\min \left(u_{m-1}^{n}, u_{m}^{n}\right) \leq u_{m}^{n+1} \leq \max \left(u_{m-1}^{n}, u_{m}^{n}\right) .
$$

В местах выполнения данного критерия порядок схемы падает до второго.

После того как значения инвариантов Римана на следующем шаге по времени найдены, востанав $\Lambda$ ивается решение: $\mathbf{u}^{\mathrm{n}+1}=\mathbf{R} \mathbf{w}^{\mathrm{n}+1}$.

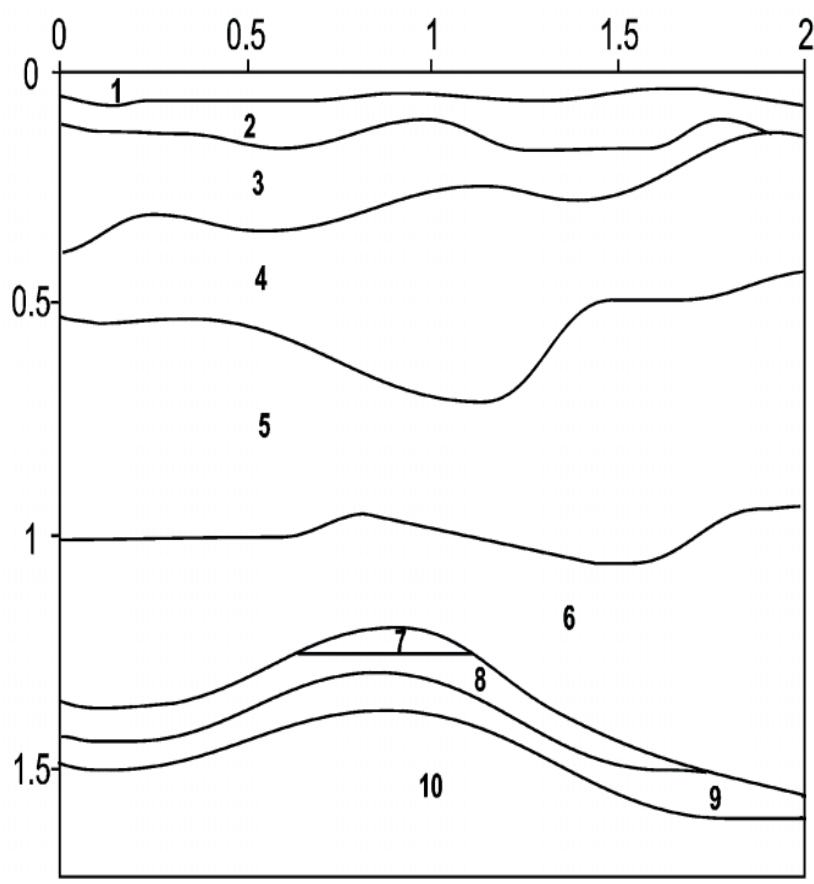

Рис. 1. Геологическая модель антиклинальной ловуики [20]

\section{4. ПОСТАНОВКА ЗАААЧИ}

Тестовая модель изображена на рис. 1. Размеры области даны в километрах. На нижней и боковых границах устанавливалось неотражающее граничное условие, на верхней - свободная граница. В качестве источника возмущения использовалась вертикальная сила, приложенная к площадке с 925.7 м по 974.1 м на Аневной поверхности, амплитуда которой описывалась импульсом Рикера частоты 40 Гц. Результаты расчета представлены на рис. 2.

\section{5. УСАОВИЯ ТЕСТИРОВАНИЯ РАСПАРАААЕАИВАНИЯ}

Bсе тесты на центральном процессоре производились на одной и той же тестовой задаче. При этом использовалась Авумерная сетка размерами $4000 \times 4000$ узлов. Выполнялось 100 шагов по времени. ОтАельно были измерены результаты Аля вычислений с одинарной и с Авойной точностью. На графиках в Аанной работе преАставлены резульаты Аля Авойной точности расчетов. Каждый узел содержал по 5 переменных, поэтому в случае вычислений с одинарной точностью вся сетка занимала в памяти 305 Мбайт, а в случае Авойной точности - 610 Мбайт.

Использовались следующие флаги компиляции: -fno-tree-vectorize, чтобы запретить векторизацию там, где мы ее не хотим использовать, -fopenmp и -pthread Аля

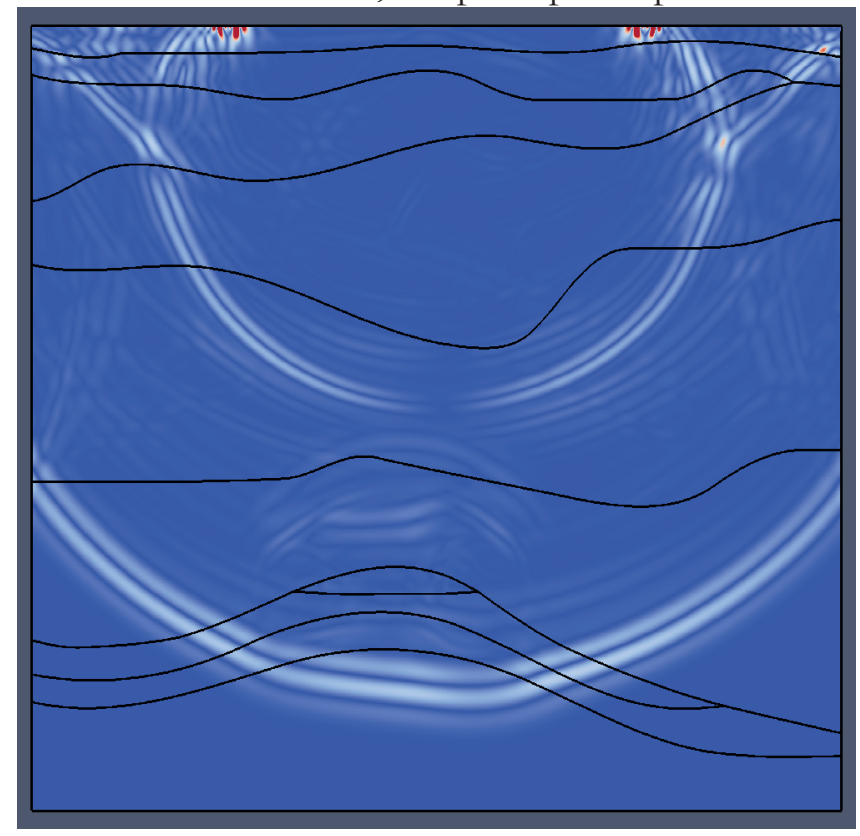

Рис. 2. Результат расиета - волновая картина в момент времени $t=0.38 \mathrm{c}$. 
Таблица 1 Центральные процессоры, на которых производилось распараллеливание

\begin{tabular}{|l|c|c|c|c|c|}
\hline $\begin{array}{c}\text { Название } \\
\text { (обозначение } \\
\text { на графиках) }\end{array}$ & $\begin{array}{c}\text { Частота, } \\
\text { ГГц }\end{array}$ & $\begin{array}{c}\text { Кеш, } \\
\text { Кбайт }\end{array}$ & $\begin{array}{c}\text { Процессоры } \\
\text { и ядра }\end{array}$ & $\begin{array}{c}\text { Компи- } \\
\text { ляторы }\end{array}$ & $\begin{array}{c}\text { Производи- } \\
\text { тельность, } \\
\text { Грлопс }\end{array}$ \\
\hline $\begin{array}{l}\text { AMD Opteron } \\
6272 \text { (a64) }\end{array}$ & 2.1 & 2048 & $\begin{array}{c}8 \text { процессоров } \\
\text { по 8 ядер }\end{array}$ & gcc4.4.6 & 1075.2 \\
\hline $\begin{array}{l}\text { Intel Xeon } \\
\text { E5-2697 (i24) }\end{array}$ & 2.7 & 30720 & $\begin{array}{c}2 \text { процессора } \\
\text { по 12 ядер }\end{array}$ & $\begin{array}{l}\text { gcc4.4.7, } \\
\text { ісс15.0.0 }\end{array}$ & 518.4 \\
\hline $\begin{array}{l}\text { AMD Opteron } \\
8431 \text { (a48) }\end{array}$ & 2.4 & 512 & $\begin{array}{c}\text { 8 процессора } \\
\text { по 6 ядер }\end{array}$ & gсc4.4.7 & 921.6 \\
\hline
\end{tabular}

задействования той или иной техологии, -О2 А^я использования стандартных оптимизаций, -msse, -mavx, чтобы явно указать какой набор инструкций мы хотим использовать при автовекторизации.

Измерения были произведены на процессорах, указанных в Табл. 1. В Аальнейшем обозначения используемых компиляторов на графиках - gсc и ісс. Обозначения Аля используемого набора векторных инструкций процессора - sse или avx.

Аля тестов на GPU рассматривалась задача с Аругими параметрами. Это была Авумерная задача с количеством узлов 4096×4096. Осуществлялось 6500 шагов по времени. В каждом узле сетки хранилось по 5 переменных с плавающей точкой. Все вычисления производицись как с одинарной (SP), так и с Авойной (DP) точностью. Размер сетки в памяти - 320 Мбайт Аля вычислений с одинарной точностью и 640 Мбайт Аля вычислений с Авойной точностью. В Табл. 2 представлены характеристики графических процессоров, на которых производились тестовые расчеты.

Таблица 2 Характеристики используемых графических карт

\begin{tabular}{|l|c|c|c|c|c|}
\hline \multicolumn{1}{|c|}{$\begin{array}{c}\text { Графический } \\
\text { процессор }\end{array}$} & $\begin{array}{c}\text { Потоковые } \\
\text { процессоры }\end{array}$ & $\begin{array}{c}\text { Тактовая } \\
\text { частота, МГц }\end{array}$ & $\begin{array}{c}\text { ГФлопс } \\
\text { (SP) }\end{array}$ & SP:DP & $\begin{array}{c}\text { ГФлопс } \\
\text { (DP) }\end{array}$ \\
\hline GeForce GT 640 & 384 & 900 & 691 & 24 & 29 \\
\hline GeForce GTX 480 & 480 & 1401 & 1345 & 8 & 168 \\
\hline GeForce GTX 680 & 1536 & 1006 & 3090 & 24 & 129 \\
\hline GeForce GTX 760 & 1152 & 980 & 2258 & 24 & 94 \\
\hline GeForce GTX 780 & 2304 & 863 & 3977 & 24 & 166 \\
\hline GeForce GTX 780 Ti & 2880 & 876 & 5046 & 24 & 210 \\
\hline GeForce GTX 980 & 2048 & 1126 & 4612 & 32 & 144 \\
\hline Tesla M2070 & 448 & 1150 & 1030 & 2 & 515 \\
\hline Tesla K40m & 2880 & 745 & 4291 & 3 & 1430 \\
\hline Tesla K80 & 2496 & 562 & 2806 & 1.5 & 1870 \\
\hline Radeon HD 7950 & 1792 & 800 & 2867 & 4 & 717 \\
\hline Radeon R9 290 & 2560 & 947 & 4849 & 8 & 606 \\
\hline
\end{tabular}

\section{6. ПРОЦЕСС ОПТИМИЗАЦИИ}

В первую очередь была написана последовательная версия алгоритма. Пересчет узАов производицся в Ава шага: по оси $X$ (обход сетки в начале по столбцам, потом по строкам) и по оси $Y$ (обход сетки в начале по строкам, потом по столбцам). Было измеренно количество арифметических операций в коде программы и из этого было полученно теоретическое значение флопс - 262, требуемое Аля пересчета одного узца. На графиках эта версия обозначается simple.

Аалее была предпринята попытка оптимизировать шаг по $Y$. На этом шаге бы изменен порядок обращения к узлам так, что он совпац с обращением в шаге по $X$. Таким образом, обращение к памяти стало последовательным, что привело к более эффективному использованию кеш-памяти. Кроме того, путем замены арифметических операций на эквивалентные, было уменьшено требуемое количество флопс Аля пересчета узла до 190. Обозначение этой версии на графиках $-\mathrm{cf}$.

После этого были векторизованы циклы, в которых обрабатывались узлы сетки. Это было саелано с помощью Аиректив (\#pragma omp simd) технологии OpenMP, появившихся в стандарте 4.0. Явно было указано какой набор инструкций Аолжен использоваться: SSE или AVX. Измерения производились только на процессоре Intel Xeon E5-2697.

Исходя из частоты ялра каждого конкретного процессора была определена его пиковая производительность. Таким образом был вычислен процент от пиковой производительности послеАовательной версии Аля каждого теста (рис. 3).

a48, gcc, cf a48, gcc, simple a64, gcc, cf a64, gcc, simple i24, gcc, cf i24, icc, of i24, gcc, simple i24, icc, simple i24, icc, cf, sse i24, icc, cf, avx

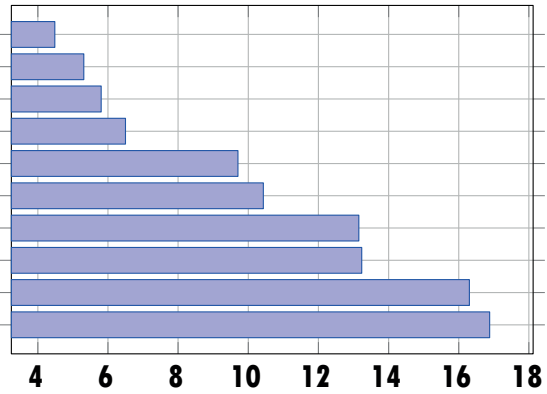

Рис. 3. Проуент от пиковой производительности. 


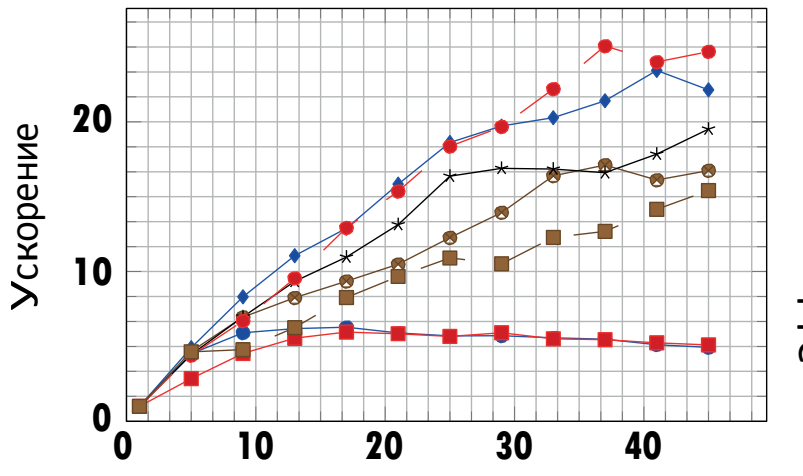

Число потоков

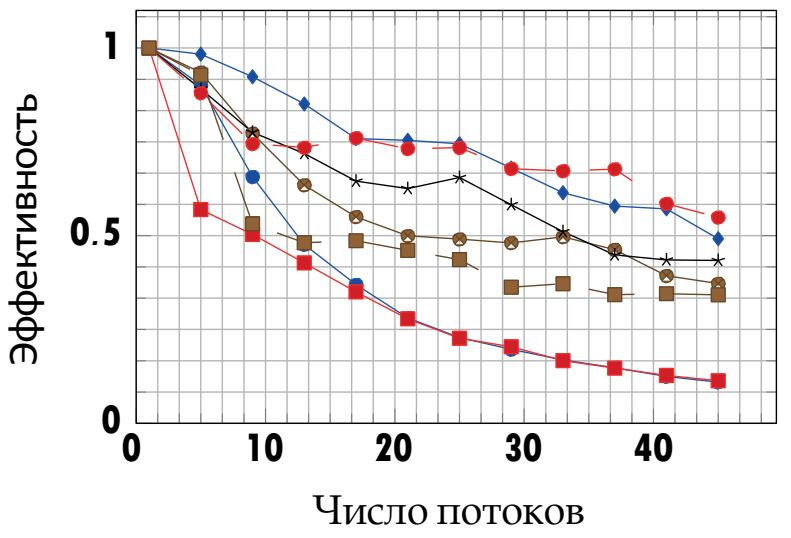

$\bullet$ simple,gcc,aff $\rightarrow$ simple,gcc $\rightarrow$ cf,gcc,aff $\multimap$ cf,gcc

- spl-gr,gcc $\ldots$ spl-gr.gcc.aff $\rightarrow$ pthread,gcc

Рис. 4. Результаты распараллеливания на AMD Opteron 8431.

\section{7. ПАРАААЕАЬНАЯ ВЕРСИЯ}

Алгоритм был распаралцелен с использованием технологий OpenMP и POSIX Threads. При этом отдельно была распараллелена каждая из версий, чтобы была возможность пронаблюдать последствия оптимизации последовательного кода на эффективность его распаралмеливания.

Быласлелана оптимизация уже паралмельного кода. В ней каждый поток выделяет память, необходимую только Аля пересчета узлов, отданных в распоряжение именно этого потока. На графиках эта версия обозначается spl-gr. Теоретически это АОАжно привести к росту производительности в NUMA системах, так как память, выделенная конкретным потоком, согласно стандарту ОреnMP выделяется в Аокальной памяти потока, обращение к которой занимает наименьшее количество времени.

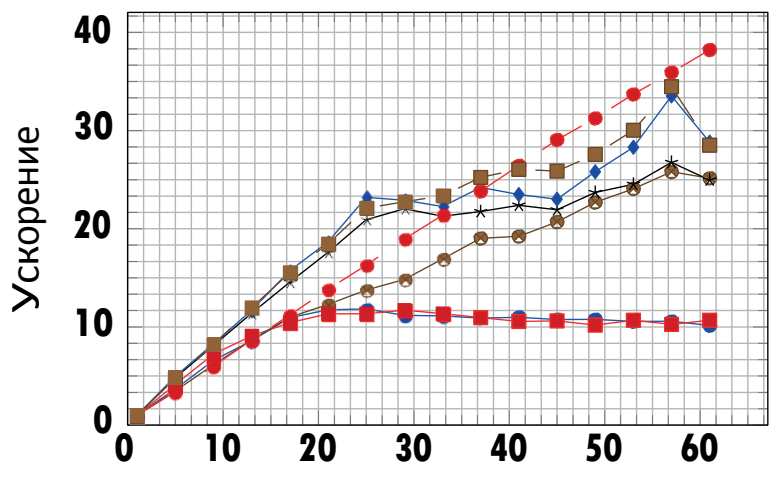

Число потоков
ОтАельно были произведены измерения, в которых потокам было запрещено перемещаться между ялрами процессора, т.е. была осуществлена "привязка" потоков к определенным ялрам процессора. Это слелано ААя уменьшения временных затрат. Без этого оптимизация, связанная с разделением сетки на отдельные части Аля различных процессов перестает иметь смысл. Результаты тестов

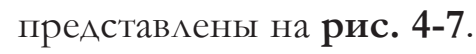

Аалее OpenMP версия кода с разделением сетки межАу потоками была изменена таким образом, чтобы использовать POSIX Threads в качестве технологии распаралмеливания.

\section{8. ОПТИМИЗАЦИЯ ААГОРИТМА НА ГРАФИЧЕСКИХ ПРОЦЕССОРАХ}

3а основу Аля реализации алгоритма на графических процессорах была взята оптимизированная Аля выполнения на

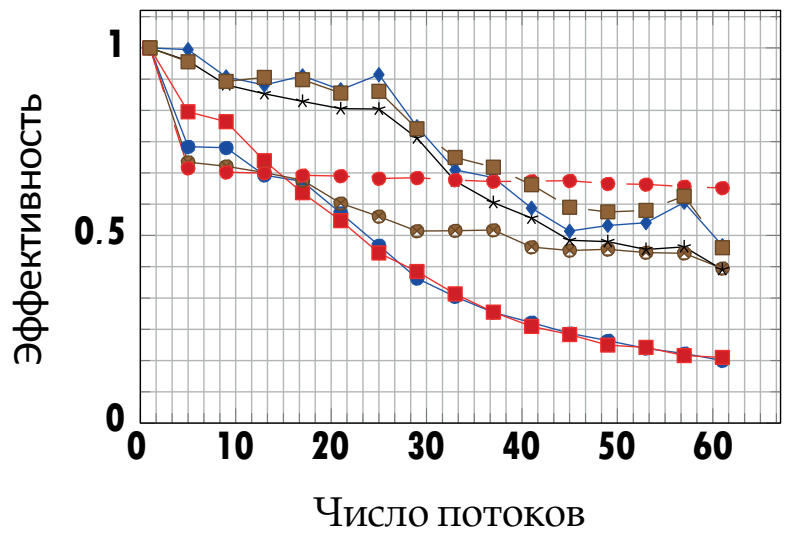

- simple,gcc,aff - simple,gcc $\rightarrow$ cf,gcc,aff
$-\quad$ spl-gr,gcc $\ldots$ spl-gr,gcc,aff $\rightarrow$ pthread,gcc

Рис. 5. Результаты распараллеливания на AMD Opteron 6272. 

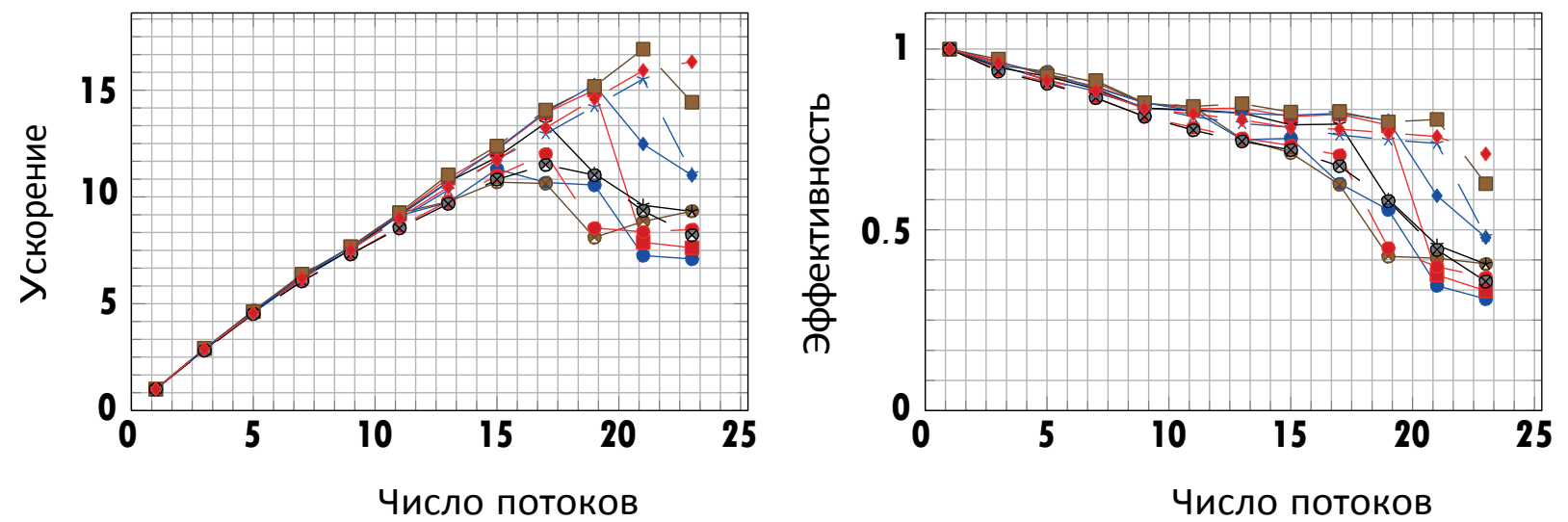

- simple,gcc - cf,gcc $\rightarrow$ simple,icc $*$ cf,icc $\rightarrow$ spl-gr,icc

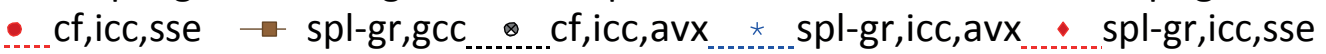

Рис. 6. Результаты распараллеливания на Intel Xeоn E5-2697 (без привязки).

центральном процессоре версия Аанной программы. Оптимизациям была подвергнута наиболеезатратнаяв вычислительномплане часть алгоритма. Так как использовалось расщепление по пространственной координате, А^я пересчета всей сетки требовалось два шага: по оси $X$ и по оси Y. При этом было вычислено количество арифметических операций с плавающей точкой, требуемое Аля пересчета оАного узма сетки за Ава шага - 190 ФАопс. Таким образом, зная количество узлов сетки, количество шагов по времени, можно было определить теоретически потребляемое алгоритмом количество ГФцопс. Аалее, зная количество потоковых процессоров в графическом процессоре, их тактовую частоту и число FMA (fused multiply-add) процессоров в одном процессоре, была вычислена пиковая производительность Аля каждого GPU. Реальные тесты алгоритма на графических процессорах показали меньшие значения производительности. На рис. 8 приведен результат тестирования. Процент от пиковой производительности алгоритмов измерялся как соотношение межАу этими Авумя значениями - теоретически требуемым количеством ФАопс А^я пересчета сетки и реально потребленным

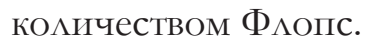

\section{1. Перенос реализации с CPU на GPU - cuda1}

В первоначальном варианте алгоритм был перенесен на выполнение на графических процессорах с использованием технологии CUDA, но не оптимизирован Аля выполнения на GPU. B ней на графическом процессоре выделялось в 2 раза больше памяти, чем требовалось Аля хранения расчетной сетки. Это стандартная практика при работе с технологиями написания алгоритмов Аля графических процессоров. В результате происходит

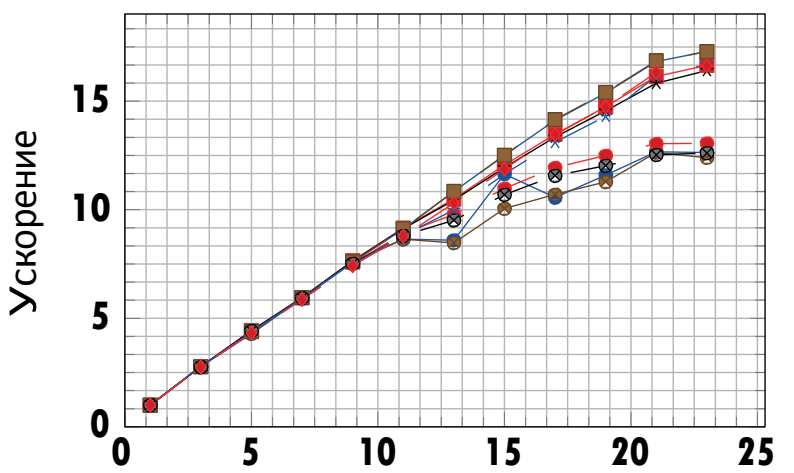

Число потоков

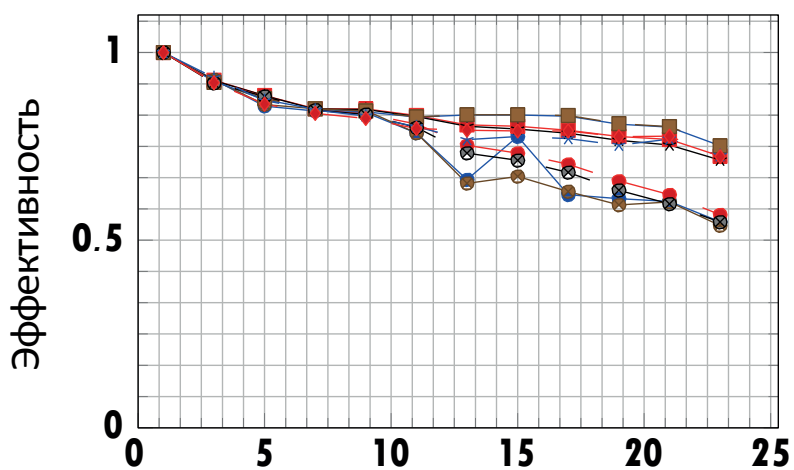

Число потоков $\rightarrow$ simple,gcc $\rightarrow \mathrm{cf}, \mathrm{gcc} \rightarrow$ simple,icc $* \mathrm{cf}, \mathrm{icc} \rightarrow \mathrm{spl}-\mathrm{gr}, \mathrm{icc}$

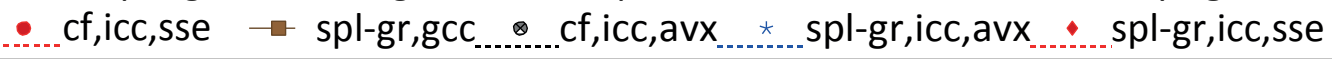

Рис. 7. Результаты распараллеливания на Intel Xeon E5-2697 (с привязкой). 


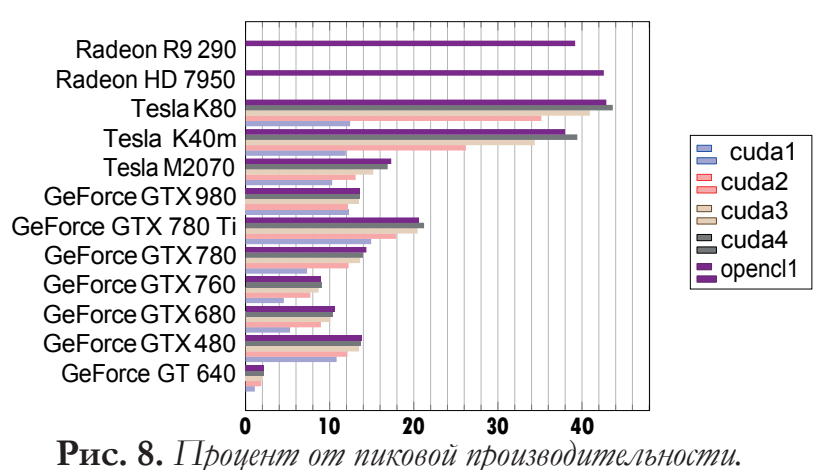

Рис. 8. Прочент от пиковой проивводительности. синхронизация только межАу вызовами функций, исполняющихся на графическом процессоре (CUDA kernels). Это было слелано по причине того, что гАобальная синхронизация всего графического процессора создает большие временные задержки, поэтому эти задержки были вставлены между вызовами kernel'ей. Таким образом, удацось уменьшить количество глобальных синхронизаций Ао Авух раз на один шаг по времени. Архитектура потоковых процессоров CUDA такова, что в оАном CUDA блоке потоки, исполняющие оАин и тот же коА наА разными областями памяти, выполняются одновременно, если нет ветвлений в коде программы. Поэтому ситуации, когда все потоки жАут завершения выполнения одного, случаются, только если этот оАин поток выполняет какие-то отличные от остальных операции.

Все операции по вылелению памяти на GPU и вызовам функций, исполняющихся на графическом процессоре, производятся хостом - CPU. Операции копирования сетки из памяти хоста и обратно требуют много времени, поэтому сетка копируется один раз из памяти хоста в память графического процессора, перед началом основных вычислений, и один раз в конце из памяти GPU в память хоста. Количество шагов по времени и размер расчетной сетки были таковы, что время, требуемое Аля расчетов, намного превосходило время, требуемое на это копирование.

Аанные в сетке можно хранить Авумя способами: в виде массива структур и в виде структуры массивов. Под структурой в Аанном случае подразумевается вектор u, состоящий из 5 компонент. В первоначацьной версии, в расчетной сетке Аанные были организованы в виде массива структур, то есть данные определенного узла лежат в памяти последовательно.
Аля задания граничных условий залачи требовацось отАичное от остальных потоков поведение на границе расчетной сетки. Аля обработки границ сетки, в коде kernel'a помещен участок кода с пятью условными блоками if-else.

А^я этой версии было перебрано несколько вариантов размера блока. Был найлен оптимаАьный размер $16 \times 16$, при котором время работы данной версии было минимально.

\section{2. Структура массивов и последовательное обращение к памяти - cuda2}

Следующая оптимизация состояла в использовании общей памяти (shared memory) блока CUDA. Это делается по причине того, что задержка (latency) при взаимодействии с этой памятью меньше, чем при взаимодействии с глобальной памятью. Оптимизация заключается в том, что чтение из глобальной памяти происходит только один раз на каждом шаге по $X$ и по $Y$ в начале вызова функции, выполняющейся на GPU, при этом данные копируются в общую память. Сразу же после этого осуществцяется синхронизация всех потоков в блоке, после чего все вычисления производятся наА Аанными в общей памяти блока. В конце kernel'a результат записывается на вторую копию расчетной сетки в глобальной памяти.

Аругая оптимизация заключалась в выборе Аругого способа хранения расчетной сетки в памяти графического процессора - структуры массивов. После этого обращения к глобальной памяти стали последовательными (coalesced), что привело к повышению производительности.

Указанные выше оптимизации позволили уменьшить количество блоков if-else при обработке границ сетки до Авух.

\section{3. Параметры вызова kernel'a - cuda3}

Ао этого Аополнительные Аанные, такие как размер сетки, материал, значения переменных, полученных в результате промежуточных вычислений, справеАливых на протяжении всех шагов по времени, передавались в качестве указате я на структуру в глобальной памяти графического процессора. Все потоки постоянно обращались к одному и тому же участку памяти. В версии алгоритма CUDA3 такие Аанные вычислялись на СРU один раз перед началом 
выполнения кода на GPU и передавались через параметры вызова kernel'a. Ожилалось, что у каждого потока будет создана цокальная копия этих значений.

\section{4. Размеры блоков - cuda4}

Важно было подобрать размеры блоков так, чтобы графический процессор был постоянно загружен, то есть чтобы не было частично не занятых потоковых процессоров. Также важно было выбрать размеры блоков, кратные размерам warp'ов, так как внутри warp'a осуществ яяется последовательный Аоступ к памяти. Аругая причина - потоки одного warp'a способны выполнять коА оАновременно наА разными участками памяти, если нет ветвлений.

В версии CUDA4 подбираются размеры блоков таким образом, чтобы удовлетворить указанным выше требованием и минимизировать количество узАов, Аля которых требуются обмены памятью межАу блоками. В шаге по $X$ Аля пересчета каждого узАа расчетной сетки требуются значения в двух смежных узлах по оси $X$, а в шаге по оси $Y$ - требуется два смежных узАа по оси $Y$. Поэтому следовало подобрать размеры блоков так, чтобы количество узлов, Аля которых требуются значения в смежных блоках, было как можно меньшим. Это необходимо было сделать, так как Аля узлов смежных блоков требуется выделение Аополнительной памяти в области общей памяти блока.

Если, например, взять блок размера $M \times N$, то в шаге по $X$ Аля хранения узлов смежных блоков потребуется $4 N$ Аополнительных узлов, а в шаге по $Y-4 M$. Поэтому в шаге по $X$ размер был выбран равным $256 \times 1$, в результате блок требовал всего 4 дополнительных узла в памяти. В шаге по $Y$ размер блока был принят равным $16 \times 16$, чтобы Аостичь компромиса межАу количеством Аополнительной памяти (64 узла сетки) и требованиями к последовательному Аоступу к памяти.

\section{5. Использование opencl1}

Следующим шагом было написание OpenCL реализации Аанного алгоритма. За основу Аля этого была взята оптимизированная версия алгоритма CUDA4.

Результаты тестирования ускорения Аля всех реализаций представленны на рис. 9.

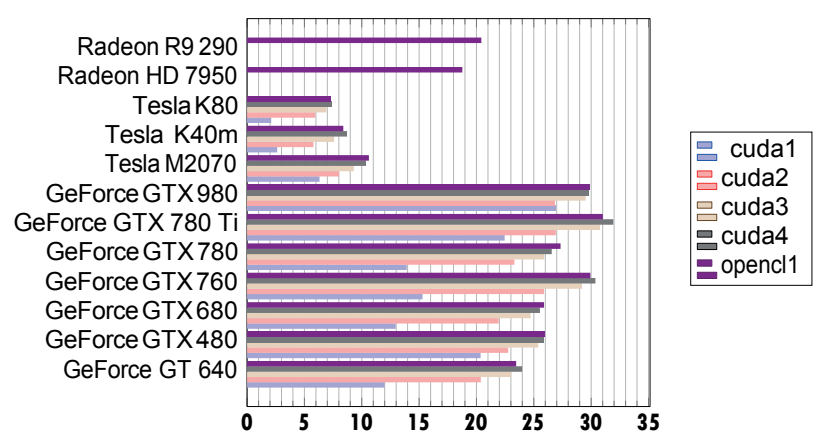

Рис. 9. Ускорение на GPU по сравненито с CPU.

Максимальное полученное ускорение по сравнению с CPU на одном графическом процессоре - в 55 раз на GeForce GTX 780 Ti в вычислениях с одинарной точностью и в 44 раза на Tesla K80 в вычислениях с Авойной точностью. Слелует отметить хорошие результаты Аля устройств от AMD, несмотря на то, что использовались Аешевые Аесктопные карты, они показали хороший результат на реализациях и одинарной и Авойной точностью.

\section{9. НЕСКОАЬКО ГРАФИЧЕСКИХ ПРОЦЕССОРОВ}

Аалее алгоритм был распаралмелен Аля работы на нескольких графических процессорах. А^я выполнения на нескольких GPU использовался наиболее оптимизированный вариант. Расчетная сетка при этом была разделена на несколько равных по размеру прямоугольных участков. Аеление производилось по оси $Y$, вследствие выбранного размера блока по оси $X$.

Тесты с использованием нескольких GPU бЫли сАеланы только Аля ОАинаковых графических процессоров. Это сАелано из-за того, что при использовании GPU с разной производительностью более быстрые процессоры окажутся причиной простоя более медленных графических процессоров, и эффект от их совместного использования может оказаться менее заметным. Синхронизация расчетной сетки межАу графическими процессорами производилась путем обмена через память хоста (CPU). Причем синхронизация производилась только ОАин раз на каждом временном шаге перед шагом по оси $Y$. Если размер сетки равен $M \times N$, а число процессоров $-D$, то число требуемых Аля синхронизации узлов сетки $-4 M(D-1)$. 


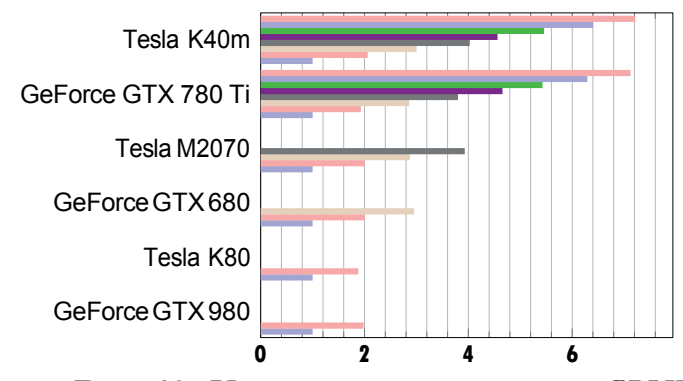

1 GPU $2 \mathrm{GPU}$ $3 \mathrm{GPU}$ 븐 $4 \mathrm{GPU}$ $5 \mathrm{GPU}$ - $6 \mathrm{GPU}$ $7 \mathrm{GPU}$ $8 \mathrm{GPU}$

Рис. 10. Ускорение при использовании GPUDirect.

Также была реализована версия на основе GPUDirect. Основное преимущество технологии GPUDirect при решении поставленной заАачи заключается в возможности пересылки данных, располагающихся в памяти графических процессоров, напрямую без участия хоста через шину PCI Express, т.е. нет необходимости копировать данные вначале с графического процессора на хост, а потом с хоста на Аругой графический процессор. Результаты тестирования приведены на рис. 10.

При использовании технологии CUDA результат отличается незначительно, при использовании в качестве буфера обмена памяти хоста. А^я технологии OpenCL результат несколько хуже.

\section{0. ЗАКАЮЧЕНИЕ}

В работе показано использование возможностей центральных процессоров и графических процессоров Аля решения задач сейсмики сеточно-характеристическим методом.

Наибольшая производительность от пиковой Аля процессора была получена в последовательной версии 22\% Аля вычислений с одинарной точностью и $17 \%$ Аля вычислений с Авойной точностью с оптимизацией Аоступа к кеш памяти и использованием векторных инструкций avx.

Максимальные полученные ускорения: на AMD Opteron 6272 - в 37 раз на 64 ялрах, на AMD Opteron 8431 - в 25 раз на 48 яАрах, и на Intel Xeon E5-2697 - в 17 раз на 24 яАрах.

Таким образом удалось продемонстрировать, что в системах с общей памятью основным ограничением Аля ускорения с ростом числа потоков яв яется максимальная скорость взаимодействия с памятью. Разделение памяти межАу потоками позволяет не обращаться ядрам процессора к нелокальной памяти, a значит Аоступ к памяти осуществ $я е т с я ~$ быстрее. Привязка потоков к определенным яАрам уменьшает количество обращений в память, используемых Аля подАержания когерентности кешей ядер, и также ведет к увеличению производительности. Следует заметить, что реализация паралмельной версии с использованием POSIX Threads оказывается сложнее, чем при использовании OpenMP, но при этом не Аает значительного прироста производительности или эффективности распаралмеливания.

В дополнение к этому, в работе были описаны методы, которые позволили достигнуть наибольшей производительности указанного алгоритма при вычислениях на GPU. Рассмотрен вопрос эффективного использования памяти графического процессора как в случае использования оАного GPU, так и в случае использования нескольких графических процессоров. Было определено влияние разАичных оптимизаций на производительность алгоритма. Максимальное полученное ускорение по сравнению с CPU на одном графическом процессоре - в 55 раз на GeForce GTX 780 Ti в вычислениях с одинарной точностью и в 44 раза на Tesla K80 в вычислениях с Авойной точностью. Аля одинарной точности удацось АОстичь производительности в 460 ГФАопс, а Аля Авойной точности была получена максимальная производительность в 138 ГФАопс. Максимальное достигнутое ускорение от количества графических процессоров - в 7.1 раз на 8 графических процессорах Аля Авойной точности. Технология GPUDirect повысила ускорение до 10\% от того, что было достигнуто без нее при вычислениях с одинарной точностью.

На основе полученных результатов можно сделать выводы о возможности применения графических процессоров ААя такого рода задач. Полученные результаты будут похожи Аля Аругих заАач,использующих похожие численныеметоды (метод конечных объемов, конечно-разностные методы). Также стоит отметить о хороших результатах аля процессоров от производителя AMD и технологии OpenCL, в то время как большинство работ используют технологию CUDA аля графических процессоров от NVidia. 
Исследование выполнено при финансовой поддержке РФФИ в рамках науиного проекта № 15-07-01931 A.

\section{МИТЕРАТУРА}

1. Caserta A, Ruggiero V, Lanucara P. Numerical modelling of dynamical interaction between seismic radiation and near-surface geological structures: a parallel approach. Computers and geosciences, 2002, 28, 9:1069-1077.

2. Guo X, Lange M, Gorman G, Mitchell L, Weiland M. Developing a scalable hybrid MPI/OpenMP unstructured finite element model. Computers and Fluids, 2015, 110:227-234.

3. Micikevicius P. 3D finite difference computation on GPUs using CUDA. Proceedings of 2nd workshop on general purpose processing on graphics processing units. ACM, 2009:79-84.

4. Nickolls J, Buck I, Garland M, Skadron K. Scalable parallel programming with CUDA. Quene, 2008, 6, 2:40-53.

5. Abdelkhalek R, Calendra H, Coulaud O, Latu G, Roman J. Fast seismic modeling and reverse time migration on a GPU cluster. HPCS'09 Intern. Conf. on High Performance Computing and Simulation, IEEE, 2009:36-43.

6. Foltinek D, Eaton D, Mahovsky J, Moghaddam P, McGarry R. Industrial-scale reverse time migration on GPU hardware. 2009 SEG Annual Meeting. - Society of Exploration Geophysicists. 2009.

7. Bohlen T. Parallel 3-D viscoelastic finite difference seismic modelling. Computers and Geosciences, 2002, 28, 8:887-899.

8. Gropp W, Lusk E, Doss N, Skjellum A. A highperformance, portable implementation of the MPI message passing interface standard. Parallel computing, 1996, 22, 6:789-828.

9. Martin R, Komatitsch D, Blitz C, Le Goff N. Simulation of seismic wave propagation in an asteroid based upon an unstructured MPI spectral-element method: blocking and nonblocking communication strategies. Intern. Conf. on High Performance Computing for Computational Science. Springer, Berlin Heidelberg, 2008:350-363.

10. Rostrup S, De Sterck H. Parallel hyperbolic PDE simulation on clusters: Cell versus GPU. Computer Physics Communications, 2010, 181, 12:164-179.

11. Aochi H, Dupros F. MPI-OpenMP hybrid simulations using boundary integral equation and finite difference methods for earthquake dynamics and wave propagation: Application to the 2007 Niigata Chuetsu-Oki earthquake. Procedia Computer Science, 2011, 4:1496-1505.

12. Vanderbauwhede W, Benkrid K. High-performance computing using FPGAs. New York, Springer, 2013.

13. Krueger J, Donofrio D, Shalf J, Mohiyuddin M, Williams S, Oliker L, Pfreundt FJ. Hardware/ software co-design for energy-efficient seismic modeling. Proceedings of 2011 Intern. Conf. for High Performance Computing, Networking, Storage and Analysis. ACM, 2011, 73 p.

14. Petrov IB, Favorskaya AV, Sannikov AV, Kvasov IE. Grid-characteristic method using high-order interpolation on tetrahedral hierarchical meshes with a multiple time step. Mathematical Models and Computer Simulations, 2013, 5, 5:409-415.

15. Golubev VI, Petrov IB, Khokhlov NI. Numerical simulation of seismic activity by the gridcharacteristic method. Computational Mathematics and Mathematical Physics, 2013, 53, 10:1523-1533.

16. Beklemysheva KA, Petrov IB, Favorskaya AV. Numerical simulation of processes in solid deformable media in the presence of dynamic contacts using the grid-characteristic method. Mathematical Models and Computer Simulations, 2014, 6, 3:294-304.

17. Butenhof DR. Programming with POSIX threads. Addison-Wesley Professional, 1997, 400 p.

18. Munshi A. The opencl specification. 2009 IEEE Hot Chips 21 Symposium (HCS). IEEE, 2009, $314 \mathrm{p}$.

19. LeVeque RJ. Finite volume methods for byperbolic problems. Cambridge university press, 2002, $558 \mathrm{p}$.

20. Carcione JM, Herman GC, ten Kroode APE. Review Article: Seismic modeling. Geophysics, 2002, 67, 4:1304-1325.

\section{Иванов Андрей Михайлович}

cтудент

Московский физико-технический институт

Аолгопрудный, 141701 Московская обц., Россия ip-e@mail.ru

Хохлов Николай Игоревич

к.ф.-M.н., с.н.с.

Московский физико-технический институт

Аолгопрудный, 141701 Московская обц., Россия k_h@inbox.ru

\section{Петров Игорь Борисович}

д.ф.-м.н., проф., илен-корр. РАН и РАЕН

Московский физико-технический институт

Аолгопрудный, 141701 Московская обц., Россия НИИ системных исследований РАН

36/1, Нахимовский просп., 117218 Москва, Россия petrov@mipt.ru 


\title{
THE USE OF PARALLEL PROGRAMMING TECHNOLOGIES FOR MODELING SEISMIC WAVES USING GRID-CHARACTERISTIC METHOD
}

\author{
${ }^{1}$ Andrey M. Ivanov, ${ }^{1}$ Nikolay I. Khokhlov, ${ }^{1,2}$ Igor B. Petrov \\ ${ }^{1}$ Moscow Institute of Physics and Technology, http://mipt.ru \\ 141701 Dolgoprudny, Moscow region, Russian Federation \\ ${ }^{2}$ Scientific Research Institute of System Analysis, Russian Academy of Sciences, https://www.niisi.ru \\ 117218 Moscow, Russian Federation \\ ip-e@mail.ru,k_h@inbox.ru, petrov@mipt.ru
}

Abstract. The paper deals with the problem of modeling seismic wave propagation in solid deformable bodies. The state of these bodies can be represented as a solution of hyperbolic system of equations. Grid-characteristic method is used to find the solution. This formulation of physical problem is used to demonstrate the use of technologies of parallel programming for shared memory systems using OpenMP and POSIX Threads technology. To achieve high performance, vector SSE and AVX instructions of CPU is used. In addition, GPU implementation is written using CUDA and OpenCL technologies. Results of multi-GPU parallelisation is also obtained. Use of NVIDIA GPUDirect technology that allows GPUs to make data exchanges directly through the PCI Express bus is considered. The paper demonstrates achieved acceleration and percentage of the theoretically possible performance. The paper demonstrates achieved acceleration and percentage of the theoretically possible performance. The paper describes the optimizations, which allowed us to achieve the obtained acceleration results.

The study was financially supported by RFBR as part of a research project number 15-07-01931 A.

Keywords: mathematical modeling, parallel programming, grid-characteristic method, shared memory, seismic, vectorization, GPU, CUDA, OpenCL

UDC 519.633 


\title{
ОБНАРУЖЕНИЕ И ИССАЕАОВАНИЕ АНОМААЬНЫХ (НЕЗАТУХАЮЩИХ) ТЕП ООВЫХ ВО $Н$
}

\author{
${ }^{1}$ Высоцкий В.И., ${ }^{2}$ Корнияова А.А., ${ }^{1}$ Васияенко А.О., ${ }^{1}$ Высоцкий М.В., ${ }^{2}$ Хаит Е.И., \\ ${ }^{2}$ Вомкова Н.X.
}

${ }^{1}$ Киевский национальный университет им. Т.Шевченко, www.univ.kiev.ua

01601 Киев, Украина

${ }^{2}$ Московский государственный университет им. М.В.Аомоносова, http://www.msu.ru

119991 Москва, Российская Федерация

Поступила 03.12.2016

Представлены результаты обнаружения и исследования принципиально нового физического явления - генерации незатухающих температурных волн, которые могут существовать в разных средах только на определенных частотах, величина которых зависит от времени мокальной релаксации теплового возбуждения в этих средах (времени термализации). В возАухе, при нормальных условиях, минимальная частота такой волны соответствует 70-90 МГц, а в металцах и полупроводниках она равна $10^{12}-10^{14} \Gamma_{ц}$. В проведенных экспериментах эти волны генерировались с помощью кавитационных процессов, а регистрировались в воздухе на расстоянии до 2 м, причем это расстояние бымо ограничено только условиями эксперимента.

Ключевые слова: кавитация, ударные волны, акустический детектор, температурная волна, уравнение теплопроводности, тепловая ремаксация

PACS: 47.55.Bx; 43.25.Yw; 43.25.Ed; 44.10.+i; 62.50.Ef; 66.70.-f

СОАЕРЖАНИЕ

1. ВВЕАЕНИЕ (196)

2. УРАВНЕНИЯ ТЕМПЕРАТУРОПРОВОАНОСТИ И ЕГО РЕШЕНИЯ ААЯ СИСТЕМЫ С ПАМЯТЬЮ (197)

3. РЕГИСТРАЦИЯ И ИССАЕАОВАНИЕ НЕЗАТУХАЮЩИХ ТЕМПЕРАТУРНЫХ ВОАН В КАВИТАЦИОННЫХ ЭКСПЕРИМЕНТАХ (199)

4. ЗАКАЮЧЕНИЕ (203)

МИтератУРА (205)

\section{1. ВВЕАЕНИЕ}

В наших предылущих исследованиях [1-6] рассматривались различные радиационные процессы, которые сопутствуют кавитации струи жидкости, выходящей поА АавАением из узкого канала. В ходе этих исследований мы наблюдали интересные физические процессы, сопутствующие взаимодействию этой струи с мишенью (в частности, возбуждением ударных волн в этой мишени и генерацией импульсного ренттеновского излучения, формируемого при внутреннем отражении этих ударных волн от противоположной поверхности мишени). Кроме того, в этих же экспериментах мы наблюдали неизвестные ранее высокочастотные волны, регистрируемые акустическим Аетектором в возАухе на достаточно большом расстоянии от этой внешней поверхности мишени. Предварительные уточняющие эксперименты показали, что частота этих аномальных волн соответствует интервалу 70- 90 МГц.

Из Аанных, хорошо известных в приклаАной акустике, следует, что такие волны, относящиеся к гиперзвуку, не могут распространяться в воздухе. Коэффициент их поглощения при нормальных ус $А$ ових

$$
\delta(\omega) \approx 10^{-12} \omega^{2} \mathrm{~cm}^{-1}
$$

в указанном интервале частоты равен очень большой величине $\delta(\omega) \approx 10^{4} \mathrm{~cm}^{-1}$, а Алина пробега не превышает несколько микрон. Более подробно эти зависимости будут рассмотрены ниже. Их регистрация явАяется своеобразным парадоксом. Этот парадокс Аополнительно усиливается тем обстоятельством, что в этих исследованиях использовались стандартные широкополосные акустические Аетекторы с резонансной частотой 1-2 МГц, эффективность которых в области гиперзвука маха. В проведенных экспериментах мы предприняли все меры предосторожности, чтобы сделать невозможным Аюбой путь попадания сигнаца от источника к Аетектору, кроме прямого распространения в воздухе. 
Проведенный нами последующий анализ показал, что эти волны соответствуют не «обычному» гиперзвуку, а являются тепловыми (температурными) волнами, которые в силу ряда особых причин являются незатухающими. Физический механизм возбуждения и распространения таких волн рассматривается ниже.

\section{2. УРАВНЕНИЕ}

\section{ТЕМПЕРАТУРОПРОВОАНОСТИ И ЕГО} РЕШЕНИЯ ААЯ СИСТЕМЫ С ПАМЯТЬЮ

Рассмотрим преАпосылки, обоснования и «слабые» места классического уравнения теплопроводности, решение которого приводит к температурным волнам.

В течение многих Аесятилетий при анализе задачи теплопроводности использовалась классическая гипотеза Фурье, согласно которой нестационарный поток тепла пропорционален граАиенту температуры

$\vec{q}(\vec{r}, t)=-\lambda \operatorname{grad}(T(\vec{r}, t))$,

и распространяется в направлении уменьшения этого градиента (напр., [7-9]). 3Аесь $\lambda$-коэффициент теп опроводности.

Если объединить (2) с законом сохранения энергии Аля $о$ окаьной области (уравнением непрерывности) в среде с объемной плотностью $\rho$ и тепцоемкостью $c_{v}$

$$
\rho c_{v} \frac{\partial T(\vec{r}, t)}{\partial t}=\operatorname{div} \vec{q}(\vec{r}, t),
$$

то можно получить классическое уравнение параболического типа Аля температурного поля

$$
\rho c_{v} \frac{\partial T(\vec{r}, t)}{\partial t}=\lambda \operatorname{div}\{\operatorname{grad}[T(\vec{r}, t)]\} .
$$

В одномерном случае решение этого уравнения представляет суперпозицию встречных плоских $\mathrm{BO} \Lambda \mathrm{H}$

$$
\begin{aligned}
& T(\omega, x, t)=A_{\omega} e^{i(\omega t-k x)}+B_{\omega} e^{i(\omega t+k x)} \equiv \\
& \equiv A_{\omega} e^{-\delta x} e^{i(\omega t-\kappa x)}+B_{\omega} e^{\delta x} e^{i(\omega t+\kappa x)}, \\
& k=\kappa(1-i), \kappa=\operatorname{Re} k=\sqrt{\omega / 2 G}, \delta=\operatorname{Im} k=\sqrt{\omega / 2 G} .
\end{aligned}
$$

Здесь $G=\lambda / \rho c_{v} \quad-\quad$ коэффициент температуропроводности.

Из этого решения виАно, что температурные волны, получаемые на основе системы уравнений (2-4), характеризуются очень сильным затуханием с коэффициентом $\delta=\sqrt{\omega / 2 G}$, который точно равен волновому чис $у$ $\kappa$.

Очевидно, что решение (5) с таким соотношением волнового числа и коэффициента поглощения, при котором практически полное поглощение волны происходит на пространственном интервале, равном Алине волны, только с большим приближением можно назвать волной.

Такие «стандартные» решения хорошо известны. Они, в частности, рассматриваются в качестве имлюстрации в по математической физике и используются при решении некоторых прикладных задач (в частности, задачи о распространении в почве предельно низкочастотной температурной волны, вызванной сезонными изменениями температуры с периодом 1 год).

Анализ исходных уравнений (2)-(4) показывает, что при их выводе неявным образом используются, как минимум, Ава важных условия - принцип мокального термодинамического равновесия и принцип локацьности. Принцип мокацьности разрешает перейти от уравнения сохранения энергии в интегральной форме к уравнению сохранения энергии в Аифференциальной (локацьной) форме. Принцип мокального термодинамического равновесия обосновывает возможность описания неравновесной системы, в которой имеется градиент температуры, концентрации и т.А., путем введения мокацьных равновесных состояний небольших подсистем. Эти очень важные принципы справедливы только Аля меАленных процессов, когАа время релаксации подсистем к равновесному состоянию $\tau$ существенно меньше характерного времени процесса (например, продолжительности теплового фронта Аля импульсного возАействия или периода колебаний Аля гармонического теп ового возАействия).

В 50-х годах 20 века в работах Cattaneо и Vernotte были слеланы попытки рассматривать нестационарные процессы теплопередачи, что привело к гиперболическому уравнению Аля температурного поля $[10,11]$. Были также рассмотрены гиперболические и нелинейные параболические модели теплопередачи с целью анализа новых режимов передачи тепла, включая режим с обострением [12]. К сожалению, эти и подобные «неполные» методы и модели не позволяют использовать тепловые процессы Аля эффективной обработки экспериментальных Аанных, связанных с взаимодействием быстрых частиц с окружающей средой (например, кристалмические мишени). 
198 ВЫСОЦКИЙ В.И., КОРНИАОВА А.А., ВАСИАЕНКО А.О., ВЫСОЦКИЙ М.В., ХАИТ Е.И., ВОАКОВА Н.Х.

Эта проблема полробно рассмотрена в наших работах [13-16]. Обсуждаемые ниже методы показывают, что более правильным и адекватным явцяется пересмотр базовых соотношений и исходных концепций, используемых без нужного ограничения при получении «стандартных» исходных соотношений (2-4). ГАавная из них относится к гипотезе об использовании цокально равновесной (термализованной) среды при выводе этих соотношений. Аیя уточнения этого обстоятельства необходимо оценить реальное время тепловой релаксации в разных среАах $[17$, 18].

В плазме время установления равновесного (максвелловского) распределения в пределах электронной поАсистемы в небольшой области равно

$$
\tau^{(e e)} \approx \sqrt{m_{e}}\left(k_{B} T_{e}\right)^{3 / 2} / 4 \pi \Lambda n_{e} e^{4},
$$

гАе $n_{e} m_{e} T_{e}-$ соответственно, концентрация электронов, масса электрона и электронная температура, $\Lambda \approx 15$ - «ку ооновский» могарифм.

А^я ионной подсистемы в плазме время релаксации равно $\tau^{(i i)} \approx \sqrt{m_{i} / m_{e}} \tau^{(e e)}$.

БАизкое к этой величине время релаксации, определяющее «максвеллизацию» электронного газа на уровнях энергии в зоне проводимости, примыкающих к уровню Ферми, соответствует времени $\tau \approx 10^{-14}-10^{-12}$ сек.

В воздухе время релаксации $\tau \approx(1.5-2) \cdot 10^{-8}$ сек определяется как Алительностью процесса «максвелмизации» поступательных степеней свободы газа $\tau_{\max }$, так и гораздо большим временем релаксации колебательных и вращательных степеней свободы молекул. При изменении температуры и, особенно, плотности и состава воздуха (например, при наличии водяных паров), величина $\tau$ может изменяться в широких пределах ( $\tau \approx 10^{-7}-10^{-8}$ сек).

Также очевидно, что время релаксации должно зависеть от интенсивности тепловой волны и от температуры среды, в которой распространяется волна. Решение такой нелинейной задачи - крайне сложная проблема.

Очевидно, что Аля тепловых процессов, протекающих существенно медленнее, чем приведенные величины $\tau$, учет релаксации будет несущественным, поскольку при описании таких процессов всегда можно использовать равновесные характеристики.

\section{НЕЛИНЕЙНАЯ ТЕРМОДИНАМИКА}

Наиболеепростой учетпроцессатемпературной релаксации (без наличия нелокальности и

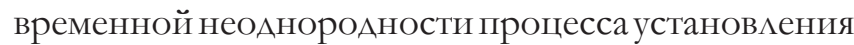
температуры) может быть осуществлен с помощью видоизмененного уравнения непрерывности

$\rho c_{v} \frac{\partial T(\vec{r}, t+\tau)}{\partial t}=-\operatorname{div} \vec{q}(\vec{r}, t)$,

соответствующего интеграАьному соотношению

$$
\frac{\partial}{\partial t} \int_{V} W_{T}(\vec{r}, t+\tau) d V=-\int_{S} \vec{q}(\vec{r}, t) \vec{n} d S,
$$

получаемому при интегрировании Аифференциального соотношения (7a) с помощью формулы Гаусса.

3десь $W_{T}(\vec{r}, t+\tau)=\rho c_{v} T(\vec{r}, t+\tau)$ - объемная плотность тепловой энергии; $\vec{n}-$ вектор внешней нормали к поверхности, окружающей объем $V$.

Из (7b) следует, что изменение полной тепловой энергии в момент времени $t+\tau$ в малом объеме $V$ опрелеляется потоком энергии $\vec{q}(\vec{r}, t)$ через поверхность $S$, ограничивающую этот объем, соответствуюшему предылущему моменту времени $t$.

Подставляя соотношение (2) в (7a), получаем уравнение температуропроводности с задержкой $\tau$, которое в оАномерном случае в оАнородной среде имеет виА

$$
\frac{\partial T(x, t+\tau)}{\partial t}=G \frac{\partial^{2} T(x, t)}{\partial x^{2}} .
$$

Решение уравнения

суперпозицией температурных волн

$T(\omega, x, t)=A_{\omega} \exp \left(-\kappa \frac{\cos \omega \tau}{\sqrt{1+\sin \omega \tau}} x\right) \exp \{i(\omega t-\kappa \sqrt{1+\sin \omega \tau} x)\}+$ $+B_{\omega} \exp \left(\kappa \frac{\cos \omega \tau}{\sqrt{1+\sin \omega \tau}} x\right) \exp \{i(\omega t+\kappa \sqrt{1+\sin \omega \tau} x)\}$,

$\cos \omega \tau \geq 0, \kappa=\sqrt{\omega / 2 G}$,

впервые полученных в работах [13-16]. КажАая из этих волн принципиально отличается от температурных волн, соответствующих «стандартному» решению (5).

А^я волн, определяемых решением (9), коэффициент затухания

$$
\delta=\kappa \frac{\cos \omega \tau}{\sqrt{1+\sin \omega \tau}}=\sqrt{\omega / 2 G} \frac{\cos \omega \tau}{\sqrt{1+\sin \omega \tau}}
$$

зависит как от коэффициента температуропроводности $G=\lambda / \rho c_{v}$, так и от времени задержки $\tau$ и частоты волны $\omega$. При предельно малом значении $\omega \tau<<1$ из (10a) находим

$$
\delta \approx \sqrt{\omega / 2 G}(1-\omega \tau / 2) .
$$

При $\tau=0$ решения (5) и $(10 \mathrm{a}, \mathrm{b})$ совпадают. 


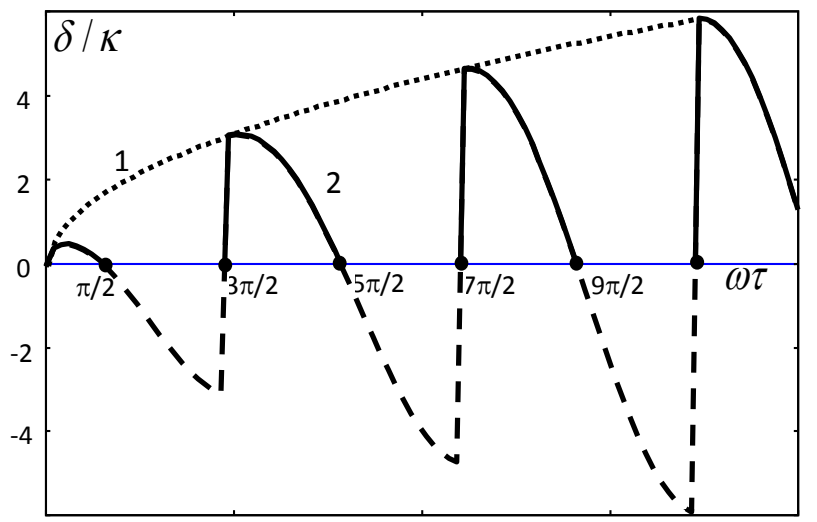

Рис. 1. Зависимость от частоть нормированного коэффичиента поглочения температурной волны: 1 решение (5) "классическое" уравнение температуропроводности (4), соответствуюшего $\tau=0 ; 2$ - решение (10) уравнения температуропроводности (8) с произвольной задержкой $\tau$.

На рис. 1 представлены частотные зависимости коэффициента поглощения «обычной» тепловой волны в среде при отсутствии задержки (при $\tau=0)$ и аналогичной волны с задержкой $(\tau \neq 0)$ (10). Коэффициент поглощения имеет физический смыс толькопри $\delta / \kappa \geq 0$ (в верхней полуплоскости). Аля графика (1) величина $\tau$ является формальным параметром, необходимым Аля сопоставления (1) и (2) в пределах одинаковой шкалы.

ВиАно, что при произвольном значении $\tau$ коэффициент поглощения тепловых волн в среде с задержкой $\tau \neq 0$ всегда меньше, чем в среде без такой задержки. Из анализа решения (9) следует, что тепловые волны могут существовать только при условии $\cos \omega \tau \geq 0$, которому соответствует физически результат - волна в среде затухает в направлении распространения. Возбуждение температурных волн с частотой, соответствующей условию $\cos \omega \tau<0$, в уравнении (9) невозможно, т.к. существование таких волн противоречит принципу причинности - их амплитуда возрастает в направ ении распространения.

Волнам с частотами

$\omega_{\mathrm{n}}=(n+1 / 2) \pi / \tau, n=0,1,2 \ldots$

соответствующими условиям $\cos \omega_{n} \tau=0$ и $\sin \omega_{\mathrm{n}} \tau=1$, отвечают Аействительные волновые числа $k_{n}= \pm \kappa_{n} \sqrt{2}$ и равный нулю коэффициент затухания, а общее решение уравнения (9) в этом случае имеет виА суперпозиции прямой и обратной незатухающих температурных волн

$$
\begin{aligned}
& T\left(\omega_{n}, x, t\right)=A_{\omega_{n}} \exp \left\{i\left(\omega_{n} t-\kappa_{n} \sqrt{2} x\right)\right\}+ \\
& +B_{\omega_{n}} \exp \left\{i\left(\omega_{n} t+\kappa_{n} \sqrt{2} x\right)\right\}, \\
& \kappa_{n}=\sqrt{\omega_{n} / 2 G} .
\end{aligned}
$$

Физический механизм формирования этих волн связан с влиянием тепловой релаксации на фазовые условия, определяющие Аиссипацию энергии тепцового Авижения.

Возбуждение таких волн возможно разными методами.

Наиболее оптимальный связан с возможным использованием АокаАьного периодического нагрева с частотой (11), соответствующей одной из таких волн. Такая система может основываться, например, на процессе взаимодействия высокочастотной электромагнитной волны с частотой $\omega_{\mathrm{n}}$ с поглощающей поверхностью. Такая поверхность будет источником незатухающих тепловых волн. Возможно также использование волн с несущей частотой, существенно превышающей $\omega_{n}$ (например, излучение казера), модулированных этой частотой.

Аругой, более простой вариант, связан с воздействием на границу межАу конденсированной средой и возАухом коротких акустических импульсов, Алительность которых $\Delta t$ АОАжна быть меньше времени $\tau$ релаксации теплового возбужАения в воздухе. В этом случае в спектре мокальных тепловых волн, формируемых в окрестности области мокального нагрева, формируемого поА Аействием этих импульсов, будут присутствовать непоглощающиеся тепловые волны с частотами, соответствующими условию (11). Именно такой случай реализуется в рассматриваемых ниже экспериментах.

\section{3. РЕГИСТРАЦИЯ И ИССАЕАОВАНИЕ НЕЗАТУХАЮЩИХ ТЕМПЕРАТУРНЫХ ВОАН В КАВИТАЦИОННЫХ ЭКСПЕРИМЕНТАХ}

Исследование особенностей распространения в воздухе волн, которые не относятся к электромагнитным и акустическим колебаниям и образование которых было стимулировано на поверхности мишени очень короткими механическими ударами, связанными с кавитационными явлениями в жидкости, было проведено на основе нескольких систем, используемых нами при проведении экспериментов по кавитации струи воды $[1,4$, $5,17,18]$. Схема одной из них представлена на рис. 2 .

В этой системе вода поА Аавлением 250 атм прокачивалась по каналу через форсунку малого Аиаметра в кавитационную камеру. На выходе 

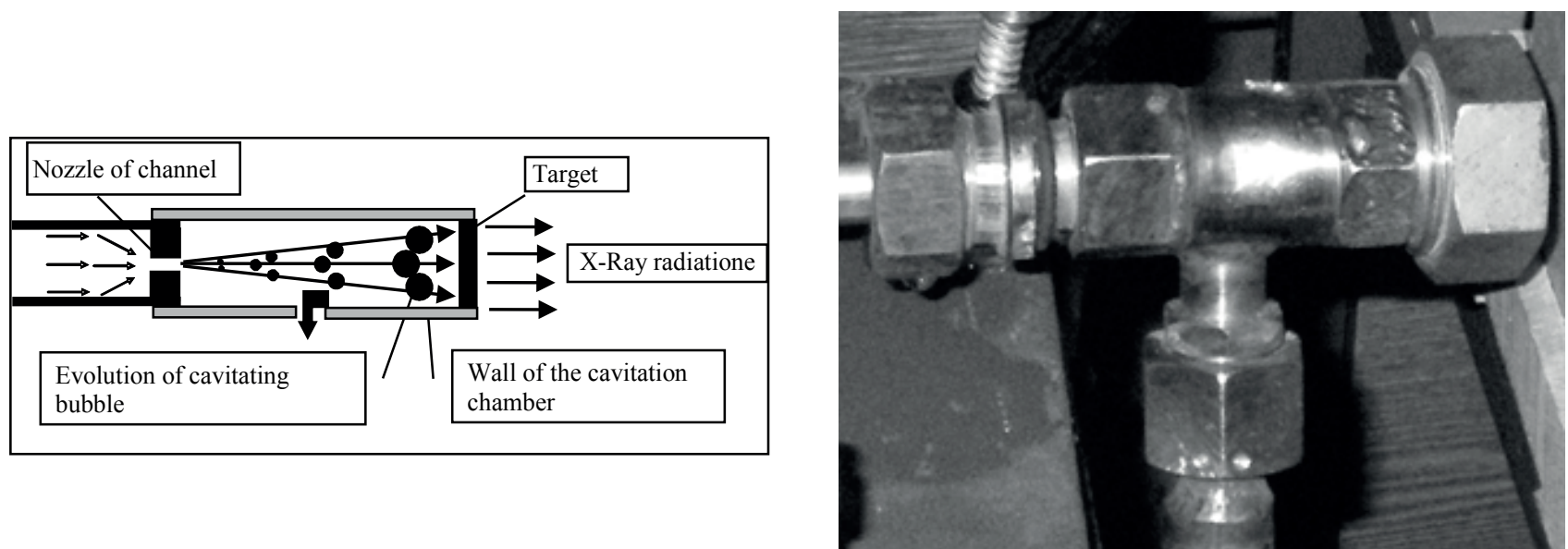

Рис. 2. Схема и фотография установки для формирования рентгеновского излучения при кавитачии струи водвг в закрвгтой камере.

канала возникацо пузырьковое кавитационное облако, формируемое процессом развития кавитационных пузырьков в Авижущейся струе воды. Воздействие этой струи на внутреннюю поверхность металиической мишени формировало интенсивные ударные волны. Внутренняя поверхность метац^ической мишени находицась на расстоянии 14 мм от выходного отверстия канала, а пространство межАу этой поверхностью и форсункой образовывало кавитационную камеру.

А^я регистрации упругих волн в возАухе за внешней стороной металмической мишени использовался широкополосный акустический приёмник из пьезокерамики ЦТС-19 Аиаметром 20 мм и резонансной частотой 1 МГц.

В первых экспериментах приёмник перемещался вАОАь оси установки в интерваце расстояний от 5 мм Ао 21 см от внешней поверхности мета^лической мишени. Измерения проводились сшагом 1 см. При контрольных измерениях приемник поворачивался относительно оси установки под углами 0, 20, 90 и 180 граАусов. В экспериментах использовались мишени из вольфрама и молибдена.

На рис. 3 представлен виА сигналов, регистрируемых приемником на разных расстояниях от мишени из вольфрама. ВиАно, что в пространстве за мишенью (в возАухе) регистрирова^ись как низкочастотные (НЧ), так и высокочастотные (ВЧ) сигналы, частота которых слабо изменялась с расстоянием.

Простой анализ показывает, что низкочастотный сигнал с частотой

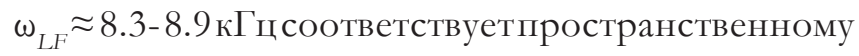
акустическому резонансу, существующему в пределах кавитационной камеры. Этот резонанс соответствовац «петле положительной обратной связи», осуществляемой при последовательном Авижении ударной волны от мишени через стенки кавитационной камеры до форсунки канаца и соответствующей модуляции параметров этой форсунки, вАияющих на темп формирования кавитационных пузырьков в струе воды. Этот резонанс способствовац установ ению режима периодической синхронизованной кавитации струи жилкости, при которой кавитационные пузырьки возникали и формировались не спорадически, а синхронизованными группами.

Такая система аналогична классическому электронному генератору Ван-дер-Поля. Небольшое изменение этой частоты может быть связано с обратным воздействием низкочастотных акустических волн, отраженных от приемника в направ Аении к мишени.

Амплитуда низкочастотного сигнала по мере удаления приёмника от мишени спадает и характеризуется апроксимационным коэффициентом убывания волны $\delta_{L F} \approx 0.05 \mathrm{~cm}^{-1}$. Это затухание Аостаточно хорошо согласуется с законами акустики и определяется совместным Аействием Авух факторов: a) "обычному" Аинейному затуханию низкочастотной звуковой волны; b) Аифракционному расширению фронта низкочастотной волны, генерируемой ограниченным по апертуре источником.

Принципиально Аругая ситуация соответствует процессу регистрации ВЧ сигнала, амплитуда которого возрастает с увеличением расстояния ВЧ волны по мере удаления от мишени синхронно с уменьшением амплитуды НЧ волны! Эти результаты представлены на рис. 4. 
Возможное объяснение этого удивительного феномена может быть связано с гипотетической перекачкой части тепловой энергии из одной волны
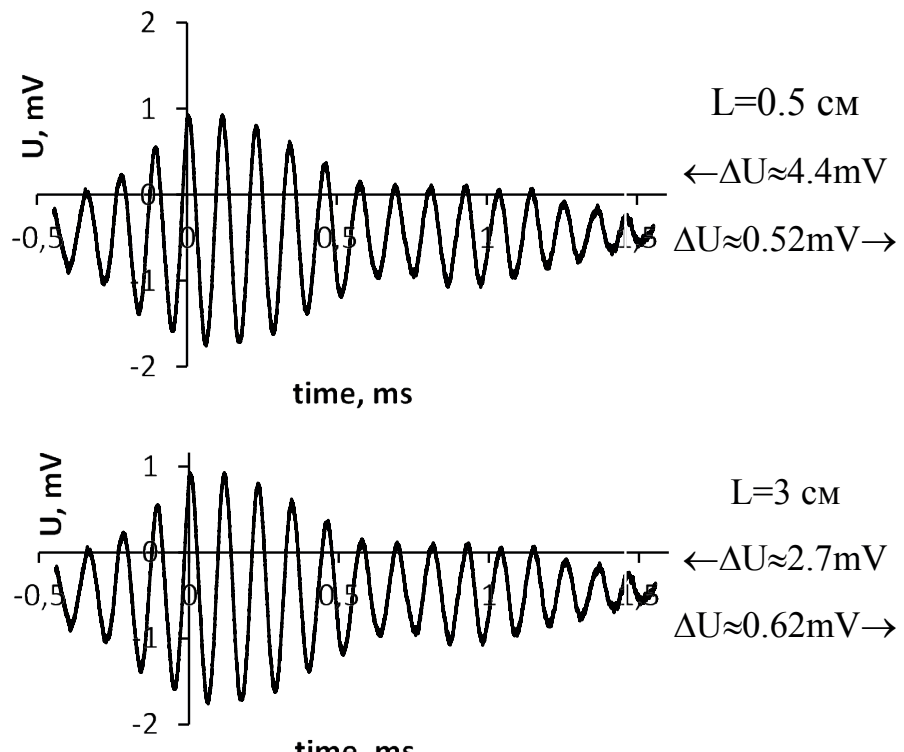

time, ms
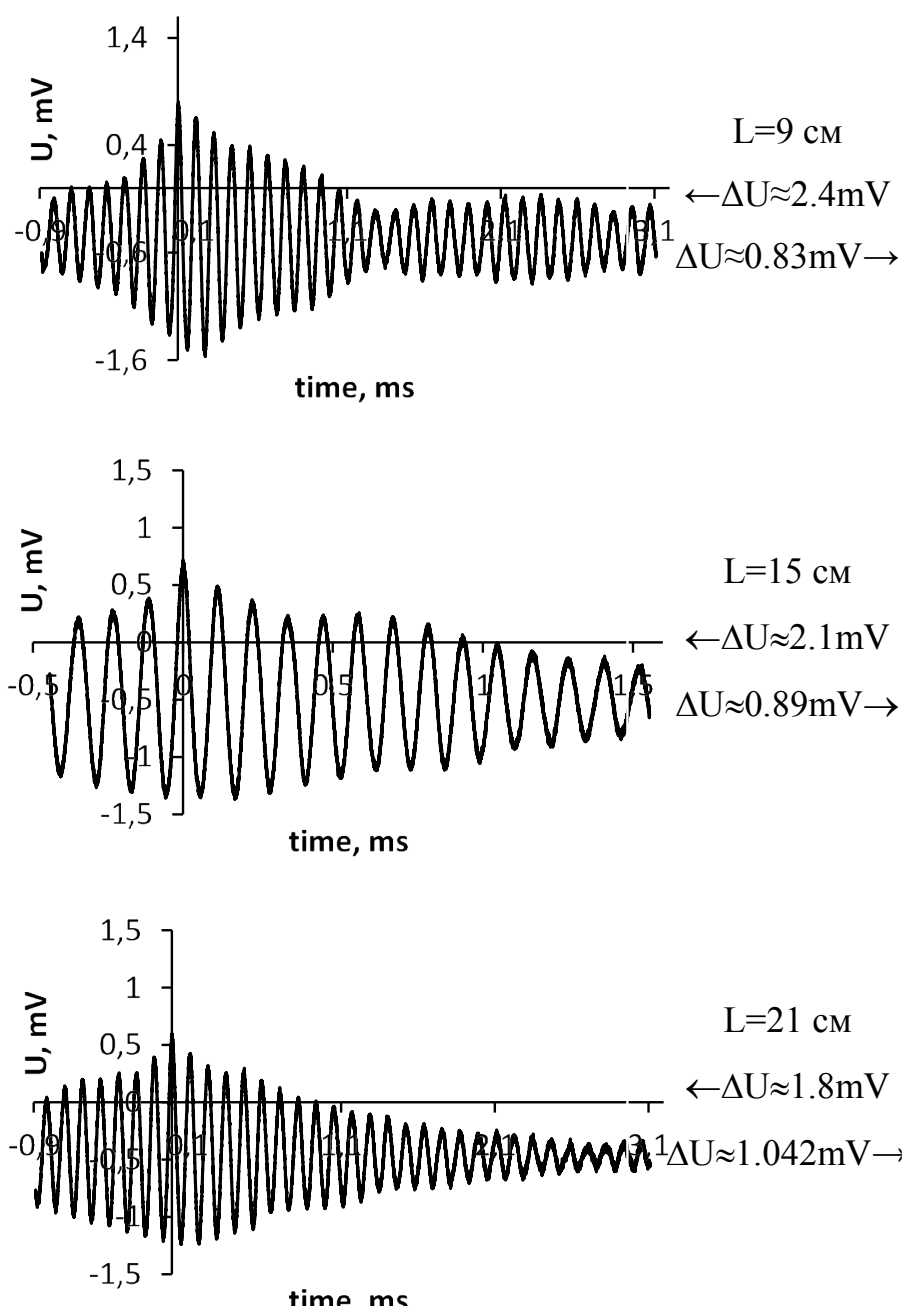

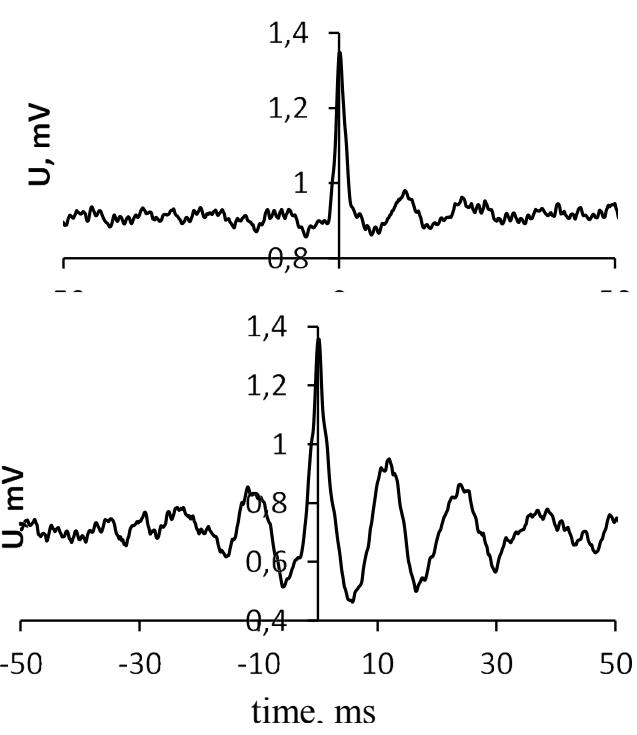

time. $\mathrm{ms}$
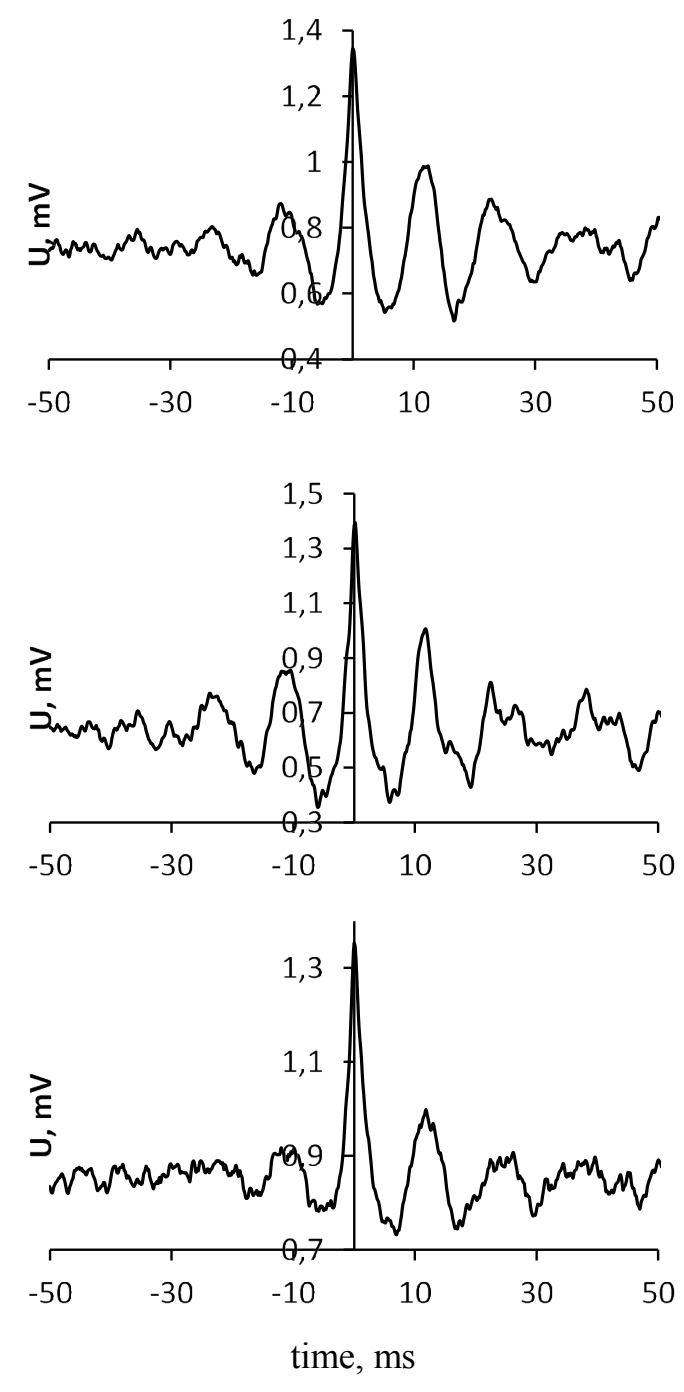

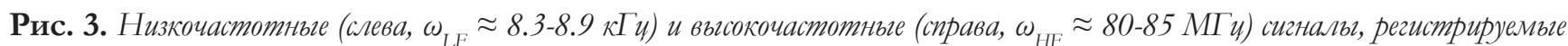
акустическии приемником, находящемся в воздухе на разных расстояниях L от мишени. Амплитудв регистрируемвгх сигналов $\Delta U$ представлень около соответствуночих графиков. 


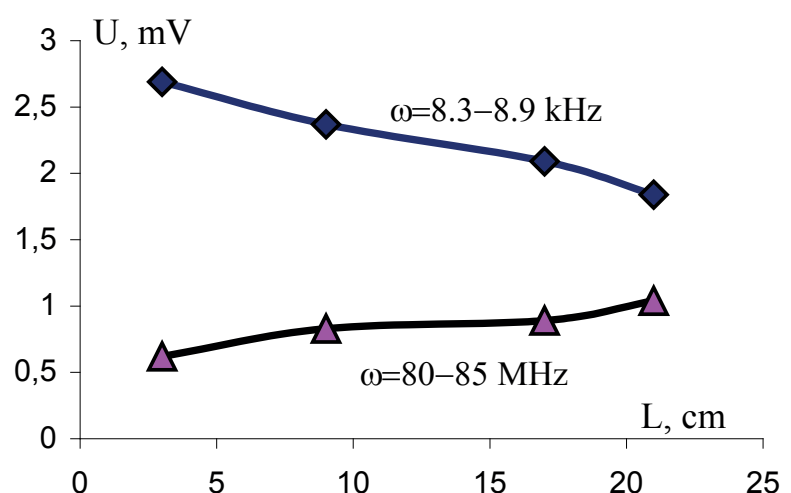

Рис. 4. Синхронное изменение амплитуд низкочастотной и выгскочастотной тепловъгх волн в воздухе при изменении расстояния от источника до места регистрачии.

высокочастотной тепловой волны). Механизм такого процесса пока не определен.

На больших расстояниях от мишени наблюдается насыщение амплитуды. Максимальное значение амплитуды этой волны соответствовацо расстоянию 21 см. Необходимо указать, что оба сигнала (как низкочастотный, так и высокочастотный) убывали по амплитуде при поворотах приёмника в вертикальной и горизонтацьной плоскостях. Это свилетельствует о том, что сигналы были эмитированы мишенью и не являлись фоном.

Необходимо сразу отметить, что регистрация акустического сигнаца с частотой $\omega \approx 80$ 85 Мгц на расстоянии $L=10-20$ см от внешней (противоположной по отношению к паАающей на мишень струе воды в состоянии кавитации)

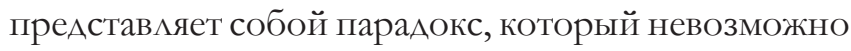

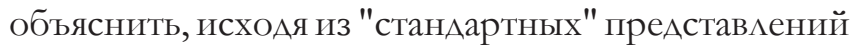
акустики. Этот вывод непосредственно следует из

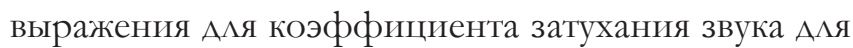
газов и жилкостей (напр., [19])

$$
\delta(T)=\frac{\omega^{2}}{2 \rho\{c(T)\}^{3}}\left[\left(\frac{4}{3} \eta+\xi\right)+\lambda(T)\left(\frac{1}{c_{V}}-\frac{1}{c_{P}}\right)\right],
$$

гае $c(T) \approx\left(331.3+1.21 \mathrm{~T}^{\circ}\right) \cdot 10^{2} \mathrm{cм} /$ сек - скорость звука, $\varrho-$ плотность воздуха, $c_{p}=1000($ Аж/кг К $)$ и $c_{v}=717($ Аж/кг К $)$ - удельные теплоемкости воздуха при комнатной температуре и нормацьном Аавлении при постоянном Аавлении и объеме, $\eta=$ $1.9 \cdot 10^{-5}(\Pi а \cdot c)$ и $\xi .=7.2 \cdot 10^{-6}(\Pi а \cdot c)-$ коэффициенты сАвиговой и объемной вязкости воздуха, $\mathrm{T}^{\circ}-$ температура в градусах Цельсия.

Из этой формулы следует, что распространение гиперзвука с частотой $\omega \approx 80-85$ Мгц в воздухе при комнатной температуре соответствует очень большому коэффициенту затухания $\delta(T) \approx 10000 \mathrm{~cm}^{-1}$. Аیина пробега такой волны в воздухе не превышает $<>\approx 1-2$ мкм, что в 10000 раз (!) меньше результатов экспериментов.

Этот результат становится еще более парадоксальным, если учесть, что резонансная частота используемого акустического детектора была 1 МГц, что в 85 раз меньше частоты регистрируемого сигнала и свидетельствует о Аостаточно низкой эффективности регистрации. Исходя из этого очевиАно, что реальная амплитуда ВЧ сигнала в месте нахождения акустического детектора была очень большой.

Второй парадокс связан с обсужденным выше эффектом пространственного возрастания амплитуды ВЧ волны, которое синхронизовано с соответствующим убыванием амплитуды НЧ волны.

Эти парадоксы могут быть естественным образом разрешены, если считать, что ВЧ волна является не акустической, а незатухающей температурной волной, рассмотренной выше.

Частота этой волны хорошо согласуется с результатами расчета.

В воздухе время релаксации определяется как Алительность процесса «максвелизации» $\tau_{\max v}$, так и более Алительными процессами внутренней и взаимной релаксации колебательных и вращательных состояний молекул $N_{2}$ и $O_{2}$. Величина $\tau_{\max \text { v }}$ зависит от среднего сечения $\sigma \approx \sqrt{2} \pi D^{2}$ упругого рассеяния близких по размеру молеку $\mathrm{N}_{2}$ и $\mathrm{O}_{2}$ (их диаметр можно принять равным $D \approx 3 \mathrm{~A})$, составляющих основу воздуха, средней скорости молекул газа $v=\sqrt{3 k T / m} \approx 4.6 \cdot 10^{4} \mathrm{~cm} / \mathrm{c}$ и полной концентрации молекул $n \approx 3 \cdot 10^{19} \mathrm{~cm}^{-3}$. При нормальных условиях (нормальное Аавление и комнатная температура) находим

$$
\tau_{\max v} \approx 10 / n<\sigma(v) v>\approx 10 \sqrt{m / 3 k T} / n<\sigma>\approx 2 n s \text {. (14) }
$$

Учет релаксации вращательных и колебательных состояний молекул позволяет характеризовать

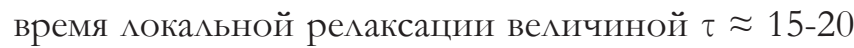
$n s$, что соответствует оценке минимальной частоты незатухающей температурной волны в интервале $\omega_{0} \approx 70-90$ МГц и изменяется при вариациях

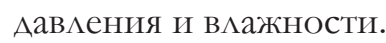

Еще одна серия исследований была проведена при использовании аналогичного экспериментального оборудования, в основе которого межит установка KMT, рассмотренная в работах $[17,18]$. Принципиальная схема этой установки аналогична представленной на рис. 2, а отличие состоит только в направлении свободного выхода струи воды. Цель этих исследований состояла в 

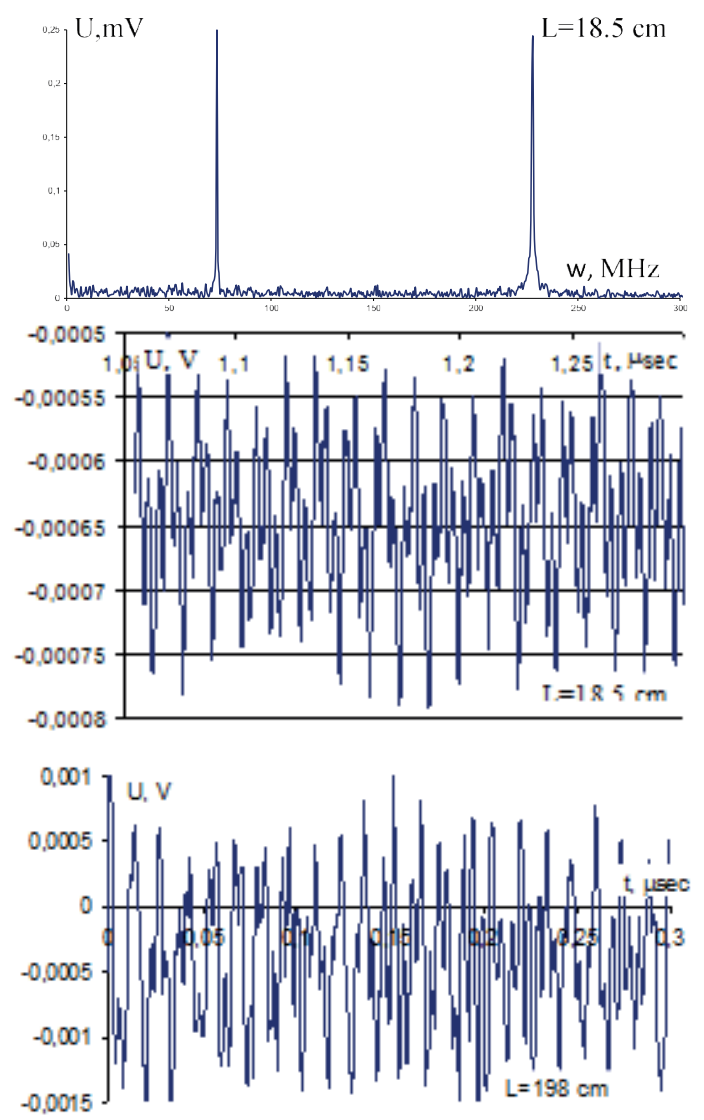

Рис. 5. Часть панорамного спектра сигналов, регистрируемвих акустическии детектором, находяиимся на расстоянии $L=18.5$ ст от внеиней поверхности мишени, и фрагменты регистрируемого сигнала на расотоянии $L=18.5 \mathrm{~cm} \mathrm{и} \mathrm{L}=198 \mathrm{~cm}$.

изучении возможности распространения температурных волн на существенно большее расстояние.

На рис. 5 представлен фрагмент панорамного спектра регистрируемых волн в области частот Ао 300 МГц при $L=18.5$ см, а также фрагменты регистрируемого сигнала на расстоянии $L=18.5 \mathrm{~cm}$ и $L=198$ см от места образования этих волн (внешней поверхности трубки, сквозь которую проходила струя воды). Аналогичный панорамный спектр фиксировался и на Аругих расстояниях от измучающей поверхности (0.5, 18.5, 100 и 198 см).

Частоты сигналов, регистрируемых акустическим детектором с резонансной частотой 1 МГц, соответственно равны $\omega_{0} \approx 74$ МГц и $\omega_{1} \approx 225$ МГц, хорошо согласуются с формулой (11), определяющей спектр незатухающих температурных волн. Отличие самой низкочастотнойизэтихволнотчастот $\omega \approx 80-85$ МГц, регистрируемых в предылущем эксперименте, может быть связано с тем, что эти частоты определяются временем тепловой релаксации (14), которое изменяется при изменении плотности, температуры и состава воздуха. Поскольку в
Аанном эксперименте струя воды после генерации ударных волн выходила в свободное пространство, то это приводило к повышенной вАажности воздуха в пространстве около экспериментальной установки и, в итоге, могло немного изменить время релаксации (от $\tau=\pi \omega_{0} / 2 \approx 18.4-19.6$ нс при $\omega_{0} \approx 80-85$ МГц АО $\tau=\pi \omega_{0} / 2 \approx 21$ нс при $\omega_{0} \approx 74$ МГц). Очевидно, что аналогичная причина (в частности, небольшое изменение температуры окружающего воздуха около экспериментального оборудования, работающего в течение Алительного эксперимента, Алившегося несколько часов с сопутствующей перестановкой и фиксацией летектора на разные расстояния, и соответствующее изменение концентрации молекул) объясняет небольшое отличие частот во н $\omega_{0} \approx 80-85$ МГц, регистрируемых на разных расстояниях.

Несмотряна то, что этиволны регистрировались на существенно разном расстоянии от места образования $(L=18.5$ см и $L=198$ см), их амплитуды на выходе системы регистрации оказались одинаковыми и равными $U_{\max } \approx 1$ милАивольт, что подтверждает отсутствие их затухания в воздухе.

\section{4. ЗАКАЮЧЕНИЕ}

Проведенные эксперименты свидетельствуют о регистрации неизвестного ранее до наших работ явления - генерации и распространения незатухающих высокочастотных тепловых (температурных) волн с частотой $\omega_{0} \geq 75-85$ МГц, которые регистрируются акустическим детектором на большом расстоянии (Ао 2 м) от источника.

Следует отметить, что это расстояние было ограничено только размерами маборатории и следует ожидать, что такие волны будут без затухания распространяться на значительно большее расстояние. Эти волны принципиально отличаются от «классических гиперзвуковых волн мегагерцового Аиапазона, которые не могут распространяться в воздухе и затухают на очень малом расстоянии (единицы и десятки микрон) от места возбуждения.

Эти незатухающие тепловые волны могут возбужАаться и распространяться только в средах с конечным (отАичным от нуля) временем Аокальной термодинамической релаксации, а их частота полностью определяется этим временем.

Показано, что частота этих волн зависит от параметров среды распространения (в Аанном случае - воздуха). Условие возбуждения таких 
волн связано с очевидным требованием, чтобы в спектре теплового возбужАения присутствовали спектральные компоненты на этих частотах. Это условие накладывает очевидное ограничение на параметры тепловых импульсов - их Алительность Аолжна быть настолько малой, чтобы в спектре присутствовали необходимые частоты.

Используемый метод возбуждения тепловых волн за счет воздействия уАарных волн при кавитации УАовлетворяет этим условиям, поскольку минимальная Алительность переднего фронта сформировавшейся ударной волны равна $\Delta t_{\min } \approx \Delta l / v_{S W}$, гАе $\Delta l \approx 10 d$ - протяженность фронта ударной волны, определяемая средним расстоянием $d$ между атомами или молекулами, $v_{S W}$ - скорость ударной волны, определяемая числом Маха и скоростью звука в данной среде.

В метальах и Аругих конденсированных среАах $v_{S W} \approx(2-5) \cdot 10^{5} \mathrm{cм} / \mathrm{c}, d \approx(1.5-2) A$ и $\Delta t_{\min } \approx(0.3-0.8) \cdot 10^{-13}$ с. Соответственно в возАухе при нормальном Аавлении $v_{S W} \approx(0.5-1) \cdot 10^{5} \mathrm{~cm} / \mathrm{c}$, $d \approx n_{\text {air }}^{-1 / 3} \approx 30 \AA$ и $\Delta t_{\text {(air)min }} \approx 10^{-12} \mathrm{c}$.

Из этих оценок следует, что при оптимальных условиях, соответствующих формированию ударных волн, максимальная частота незатухающих тепловых волн в воздухе может Аостигать $\omega_{\max } \approx 1 / \Delta t \approx 1$ ГГц. Эта оценка очень хорошо согласуется с результатами рассматриваемого выше эксперимента. На рис. 6 представлена высокочастотная часть общего панорамного спектра регистрируемых тепловых волн, более низкочастотная часть которого представлена выше на рис. 5.

Из вила этого спектра следует, что максимальная частота незатухающих тепловых волн при данном методе возбуждения достигает $\omega_{\max } \approx 1 \Gamma \Gamma_{ц}$

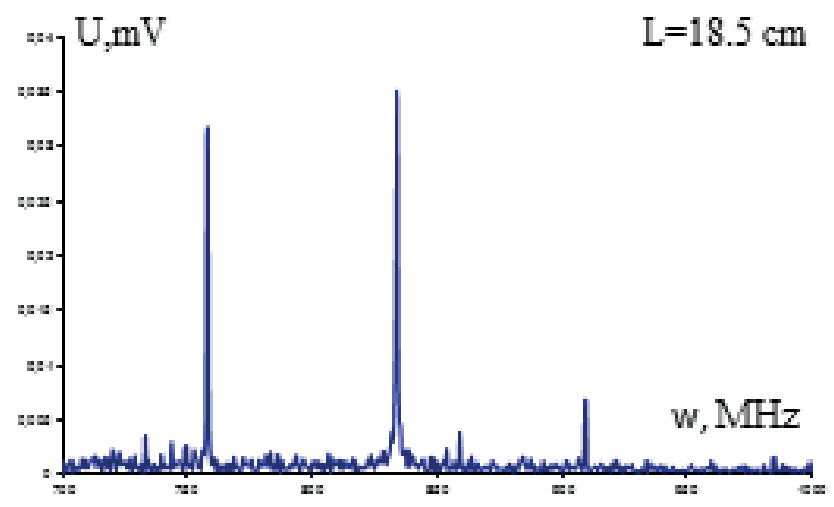

Рис. 6. Вигокочастотная часть панорамного спектра сигналов, регистрируемьгх акустическим детектором, находящимся на расстоянии $\mathrm{L}=18.5 \mathrm{~cm}$ от внешней поверхности мишени. что полностью согласуется с результатами теоретической оценки.

Эти волны имеют очень малую скорость распространения, которая, согласно расчетам, оказывается намного меньше, чем скорость обычного звука и не превышает 50-100 м/с.

В заключение можно указать еще на один потенциально возможный фактор импульсной генерации температурных волн на выходной (наружной) поверхности экрана или трубки, на внутреннюю поверхность которых воздействуют акустические ударные волны, вызванные кавитацией струи воды. Ранее в качестве основного механизма возбуждения тепловых волн околО этой внешней поверхности (правой поверхности мишени на рис. 2) нами рассматривался процесс внутреннего отражения ударных волн от этой поверхности с соответствующим резким «встряхиванием» и ионизацией поверхностных атомов, что ведет к генерации мягкого рентгеновского излучения и очень быстрого нагрева приповерхностного слоя возауха.

Результаты исследований последнего времени показывают, что существует еще один механизм такого импульсного нагрева, связанный с особенностями ударного импульсного воздействия на атомы.

В работах [20-22] было показано, что при быстрой (импульсной) обратимой деформации нестационарного гармонического осциляятора происходит формирование когерентных коррелированных состояний частиц, которые находятся в нестационарном параболическом поле, соответствующему этому осцим^ятору. Специфика этого состояния приводит к синхронизации квантовых флуктуаций в суперпозиционном состоянии и формированию гигантских флуктуаций импульса и кинетической энергии, которые на много порядков превышают средние значения. Результатом этого процесса явАяется резкое возрастание вероятности химических и ядерных реакций с участием частиц, находящихся в параболическом поле и частиц, которые это поле создают и, соответственно, сопутствующее этому импульсное вылеление энергии. В частности, в этих работах было показано, что при таком модулирующем воздействии флуктуации кинетической энергии частиц (в частности ядер атомов) могут Аостигать 10-50 кэВ при средней тепловой (комнатной) энергии мишени на уровне $k T \approx 0.025$ эB! 
Простой анализ показывает, что процесс прохождения ударной волны по конденсированному веществу хорошо согласуется с этим сценарием усиленного энерговыделения. Аействительно, при Авижении ударной волны сквозь такую среду происходит сильное сжатие вещества на ее переднем фронте и растяжение на заднем. Аля каждого из атомов среды, находящегося в окружении ближних соседей, это эквивацентно нестационарной импульсной Аеформации гармонического осцициятора, поле которого формируют ближайшие сосеАи. Особо сильно такой эффект, ведущий к формированию когерентных коррелированных состояний, проявцяется на внешней (выходной) поверхности кавитационной камеры, где происходит отражение ударных волн от границы плотного материала стенки камеры с воздухом. Косвенное подтверждение такого механизма энерговыделения состоит в обнаружении на этой внешней поверхности чужеродных химических элементов, которые отсутствова^и в ее составе Ао воздействия на мишень струи воды с кавитационными пузырьками. Такие элементы могут быть результатом протекания импульсных ядерных реакций с участием ядер мишени и ялер атомов, входящих в состав воздуха. Такой процесс явАяется предельно коротким и его Алительность определяется временем существования когерентного коррелированного состояния [20-22].

Мы планируем исследовать этот сценарий при проведении дополнительных и более Алительных экспериментов.

\section{МИТЕРАТУРА}

1. Vysotsky VI, Kornilova AA, Korneeva YuV, Krit TB. Issledovanie anomalnykh radiatsionnykh i teplovykh yavleniy pri kavitatsii strui zhidkosti. 1. Anomal'nye effekty pri generatsii rentgenovskogo izlucheniya, stimulirovannogo protsessom kavitatsii zhidkosti [The study of abnormal radiation and thermal phenomena in the cavitation jet fluid. 1. Anomalous effects in the generation of X-rays, stimulate fluid cavitation]. Inzhenernaya fizika, 2016, 2:33-45 (in Russ.).

2. Kornilova AA Vysotsky VI, Koldamasov AI, Hyun Ik Yang, Denis B. McConnell, Desyatov AB. Generation of intense directional radiation during the fast motion of a liquid jet through a narrow dielectric channel. Journal of surface investigation. X-ray, synchrotron and neutron techniques, 2007, 1(2):167-171.

3. Kornilova AA Vysotsky VI, Sysoev NN, Desyatov AB. Generation of X-rays at bubble cavitation in a fast liquid jet in dielectric channels. Journal of Surface Investigation. X-ray, Synchrotron and Neutron Techniques, 2009, 3(2):275-283.

4. Kornilova AA, Vysotsky VI, Sysoev NN, Litvin NK, Tomak VI, Barzov AA. Shock-cavitational mechanism of X-ray generation during fast water stream cavitation. Moscow University Physics Bulletin, 2010, 65(1):46-50.

5. Kornilova AA Vysotsky VI, Sysoev NN, Litvin NK, Tomak VI, Barzov AA. Generation of intense $\mathrm{x}$-rays during ejection of a fast water jet from a metal channel to atmosphere. Journal of Surface Investigation. X-ray, Synchrotron and Neutron Techniques, 2010, 4(6):1008-1017.

6. Vysotsky VI, Kornilova AA, Sysoev NN. Rentgenovskoe izluchenie pri kavitatsii bystroy strui zhidkosti [X-rays at a fast cavitation liquid jet]. Radioelektronika. Nanosistemy. Informationnye tekhnologii (RENSIT), 2010, 2(1-2):57-69 (in Russ.).

7. Shashkoff AG, Bubnov VA, Janowski SYu. Volnoyye yavleniya teploprovodnosti: sistemno-strukturny podkhod [Wave phenomena of thermal conductivity: system-structural approach]. Moscow, Editorial URSS, 2004, 296 p.

8. Telegin AS, Shwydkiy VS, Yaroshenko YuG. Teplomassoperenos [Heat and mass transfer]. Moscow, Akademkniga Publ., 2002.

9. Sobolev SL. Local non-equilibrium transport models. Physics Uspekhi, 1997, 40:1043-1053.

10. Cattaneo CR. Sur une forme de l'équation de la chaleur éliminant le paradoxe d'une propagation instantanée. Comptes Rendus, 1958, 247:431-433.

11. Vernotte P. Les paradoxes de la theorie continue de l'équation de la chaleur. Comptes Rendus, 1958, 246:3154-3155.

12. Samarsky AA, Galaktionov VA, Kurdyumov SP, Mikhaylov AP. Rezhbimy s obostreniem [The sharpening regimes]. Moscow, Nauka Publ., 1987.

13. Vysotskii VI, Vassilenko VB, Vasylenko AO. Propagation of temperature waves in medium with internal thermal relaxation. Bulletin of Taras Shevchenko National Univ. of Kyiv, Series Rafiophysics, 2013, 1:11-14.

14. Vysotskii VI, Vassilenko VB, Vasylenko AO. Periodic heat transfer regimes in active medium. Bulletin of Taras Shevchenko National Univ. of Kyiv, Series Physics \& Mathematics, 2013, 2:255-260.

15. Vasylenko AO, Vysotskii VI, Vassilenko VB. Heat transfer equation with delay for media with thermal memory. Intern. J. of Sciences: Basic and Applied Research (IJSBAR), 2015, 12(1):160-166.

16. Vysotskii VI, Vasilenko AO, Vassilenko VB, Vysotskyy MV. Nonequilibrium thermal effects during pulsed action on conducting medium. Inorganic Materials: Applied Research, 2015, 6(3):199-204. 
17. Vysotskii VI, Kornilova AA, Vasilenko AO. Observation and investigation of $\mathrm{X}$-ray and thermal effects at cavitation. Current Science, 2015, 108(4):114-119.

18. Vysotsky VI, Kornilova AA, Vasilenko AO, Tomak VI. Detecting and investigation of undamped temperature waves excited under water jet cavitation. Surface Investigation. X-ray, Synchrotron and Neutron Techniques, 2014, 8(6):1086-1192.

19. Gurbatov SN, Rudenko OV. Akustika v radachakh [Acoustics in problems]. Moscow, Nauka Publ., 1996.

20. Vysotskii VI, Vysotskyy MV. Coherent correlated states and low-energy nuclear reactions in non stationary systems. European Phys. Journal. A., 2013, 49(8):1-12.

21. Vysotskii VI, Adamenko SV, Vysotskyy MV. Acceleration of low energy nuclear reactions by formation of correlated states of interacting particles in dynamical systems. Annals of Nuclear energy, 2013, 62:618-625.

22. Vysotskii VI, Vysotskyy MV. The formation of correlated states and optimization of the tunnel effect for low-energy particles under nonmonochromatic and pulsed action on a potential barrier. Journal of Experimental and Theoretical Physics, 2015, 121 (4):559-571.
Высоцкий ВАадимир Иванович

д.ф.-м.н., ироф., илен-корреспондент РАЕН

Киевский национальный университет им. Т.Шевченко 64/13, ум. ВАадимирская, Киев 01601, Украина vivysotskii@gmail.com

Корнилова Алма Александровна

к.ф.-м.н., с.н.с., действительный илен $Р$ АЕН

МГУ им. М.В. Аомоносова, физический факультет

1/2, Аенинские горы, 119991 Москва, Россия prfnart@mail.ru

\section{Васименко Антон Олегович}

аспирант

Киевский национальный университет им. Т.Шевченко 64/13, ум. ВАадимирская, Киев 01601, Украина vivysotskii@gmail.com

Высоцкий Михаим ВАадимирович

к.ф.-м.н., ассистент

Киевский национальный университет им. Т.Шевченко 64/13, ум. ВАадимирская, Киев 01601, Украина mihas1984@gmail.com

\section{Хаит Ефим ИАьич}

ведущий электроник

МГУ им. М.В. Аомоносова, физический факультет 1/2, Аенинские горы, 119991 Москва, Россия haitov5@yandex.ru

Волкова Наиля Хасьяновна

ведущий электроник

МГУ им. М.В. Аомоносова, физический факультет 1/2, Аенинские горы, 119991 Москва, Россия haitov5@yandex.ru

\section{DETECTION AND INVESTIGATION OF ANOMALOUS (UNDAMPED) THERMAL WAVES}

\section{Vladimir I. Vysotskii, Anton O. Vasilenko, Mikhail V. Vysotskyy}

Shevchenko Kiev National University, http://www.univ.kiev.ua

64/13, st. Vladimirskaya, 01601 Kyiv, Ukraine

vivysotskii@gmail.com, vivysotskii@gmail.com,mihas1984@gmail.com

\section{Alla A. Kornilova, Efim I. Hait, Nailia H. Volkova}

Lomonosov Moscow State University, http://www.msu.ru

1/2, Leninskie gory, 119991 Moscow, Russian Federation

prfnart@mail.ru, haitov5@yandex.ru,haitov5@yandex.ru

Abstract. Results of the detection and study of fundamentally new physical phenomenon - generating undamped temperature waves, which can exist in different environments only at certain frequencies, the value of which depends on the time of the local relaxation of thermal excitations in these environments (the thermalization time) are presented. In the air, under normal conditions, the minimal frequency of such wave corresponds to 70-90 MHz and in metals and semiconductors it is 1012- $1014 \mathrm{~Hz}$. In the experiments these waves are generated via cavitation processes and registered in the air at a distance of $2 \mathrm{~m}$ and this distance is limited only by the experimental conditions

Keywords: cavitation, shock waves, acoustic detector, thermal wave, the heat equation, thermal relaxation PACS: 47.55.Bx; 43.25.Yw; 43.25.Ed; 44.10.+i; 62.50.Ef; 66.70.-f 


\title{
КВАЗИСИММЕТРИЯ ФУРЬЕ-ОБРАЗОВ ОБОБЩЕННЫХ ТРИААНЫХ ПРЕАФРАКТААОВ КОХА
}

\author{
1,2Арзамасцева Г. В., ${ }^{1}$ Евтихов М. Г., ${ }^{1}$ Аисовский Ф. В., ${ }^{1}$ Мансветова Е. Г. \\ ${ }^{1}$ Институт радиотехники и электроники им. В.А. Котельникова РАН, Фрязинский филиал, http:/ fire.relarn.ru \\ 141190 Московская обл., г. Фрязино, Российская Федерация \\ ${ }^{2}$ Современная гуманитарная академия, http://www.muh.ru \\ 109029 Москва, Российская Федерация \\ Поступила в редакиию 6.12.2016 \\ Представлена иленом-корреспондентом Р АЕН В.И. Грачевъцм
}

Численными методами выполнено исследование свойств Фурье-образов семейства плоских триадных геометрических предфракталов с генератором в виде симметричной четырехзвенной моманой с произвольным угАом при вершине межАу центральными звеньями и с инициатором в виде отрезка прямой (кривая Коха) или в виде равностороннего треугольника (снежинка Коха). Аیя получения Фурье-образов изображения исследуемых фракталов аппроксимировались сеточной функцией на равномерной сетке с ячейками, достаточно мелкими дяя адекватной переАачи деталей преАфракталов высоких поколений, а затем ААя оцифрованного таким образом изображения с помощью быстрого преобразования Фурье определялись значения кваАрата модулей Фурье-компонент, то есть спектральное распределение интенсивности дифракционных максимумов в зоне Фраунгофера. Анализ Фурье-образов показаА, что при значениях углов при вершине или при основании, равных целым долям от 180 градусов, они напоминают образы, присущие как идеальным кристалмам с осями симметрии 2-го, 3-го, 4-го и 6-го порядка, так и паркетным мозаикам ими квазикристамлам с осями квазисимметрии Аюбого порядка. Реально в Фурьеобразах кривых Коха с инициатором в виде отрезка прямой наблюдались оси квазисимметрии с 3-го до 9-го и 11- го порядка. Сходные описанным выше свойства присущи также и Фурье-образам снежинок Коха с инициатором в виде равностороннего треугольника. Конфигурацию наблюдаемых Фурье-образов можно приближенно считать радиально-кольцевой, причем в периферической («решеточной») части изображений доминирует радиальный характер с периодичностью распределения дифракционных рефлексов по радиусу, а в центральной («фрактальной») - кольцевой с самоподобием. Решеточная часть облаАает своеобразной кцастеризацией: все мучи имеют ярко выраженную центральную цепочку рефмексов вдоль радиусов и парамлемьные ей более слабые сатемлиты по обе стороны. Все Фурье-образы обладами центром симметрии, который явмяется неотьемлемым атрибутом дифракционных картин в зоне Фраунгофера Аля мюбых объектов), однако вращательная симметрия не быма идеальной: при повороте изображений на соответствующие порядку оси симметрии углы совпадали только положения Аифракционных рефлексов, а их интенсивности могли размичаться. Причина наблюАаемых особенностей заключается в том, что рассматриваемые преАфракталы, в отАичие от кристамлов, преАставАяют собой не континуум точечных объектов, а Авумерное множество отрезков прямых, имеющих одинаковую Алину, но разную ориентацию в пространстве. В этом множестве Аяя рассматриваемых нами конфигураций генератораможновыделить состоящие изодинаково ориентированныхотрезков двумерныеподмножества, каждое из которых содержит некоторое количество парциальных одномерных дифракционных решеток, образуемых расположенными вдоль одной минии отрезками. Эти парамлельные решетки в общем случае содержат разное количество отрезков, причем степень заполнения и расстояния межАу соседними отрезками, определяющие интенсивность и характер распределения дифракционных рефмексов вдоль минии, зависят от ориентации решетки и номера поколения преАфрактала.

Клочевые слова: генератор, Аифракция Фраунгофера, инициатор, квазикристамл, квазисимметрия, кривая Коха, масштабная инвариантность, паркетная мозаика, предфрактал, самоподобие, снежинка Коха, фрактал Коха, Фурье-образ, численные методы

УАК 51.74; 535.42

\section{СОАЕРЖАНИЕ:}

1. ВВеАЕНИЕ (208)

2. ПОАУЧЕНИЕ ФУРЬЕ-ОБРАЗОВ КРИВЫХ И СНЕЖИНОК КОХА (208)

3. КОНФИГУРАЦИЯ И СИММЕТРИЯ ФУРЬЕОБРАЗОВ (209)
4. СХЕМА ФОРМИРОВАНИЯ РЕШЕТОЧНОЙ И ФРАКТААЬНОЙ ЧАСТЕЙ ФУРЬЕ-ОБРАЗОВ (210)

5. ЗАКАЮЧЕНИЕ (212)

АИтерАтУРА (212) 


\section{1. ВВЕАЕНИЕ}

Фрактальная илеология, первоначально рассматриваемая только как базис экзотической ветви абстрактной математики, на современном этапе широко используется не только Аля описания и анализа различных материальных объектов и яв ений [1-4], но и настойчиво вторгается во многие сферы человеческой деятельности. Техника и технология $[5,6]$, биология и медицина [7], экономика [8, 9], искусство (музыка, живопись, митература, Аингвистика, архитектура) [10-14] - этот список мегко может быть продолжен. ОАнако, с точки зрения науки о фракталах приоритетными направлениями продолжают оставаться математика и физика [15].

В конце XX века возник заметный интерес и к изучению Фурье-образов плоских фракталов (то есть, Аифракционных картин от них в зоне Фраунгофера) (см. напр. [16-18]), который не ослабевает и поныне. В частности, это связано с тем, что по Фурье-образам можно Аовольно просто опрелелять хауслорфову размерность $D$ изучаемых объектов [16]. Авторами работ [17-18] с целью прямого опрелеления Фурье-образов впервые были выполнены эксперименты по рассеянию светана микрофотографиях снежинки Коха; полученные Аанные сопостав яялись с теорией, использующей аналитическое описание фрактала. Исследовались также особенности фраунгоферовой Аифракции и Аля Аругих фрактальных объектов: фрактала Вичека, гребня Кантора, ковра Серпинского и Ар. [19-24].

Аифракционный метод определения $D_{f}$ получиц широкое распространение, так как он применим к Аюбым объектам, вкАючая реальные фракталы, которые не подАаются ни геометрическому, ни аналитическому описанию. Однако утилитарная полезность Фурье-образов этим не ограничивается, поскольку с их помощью можно получать информацию о структуре и симметрии абстрактных фракталов, а также о фазовых переходах в реальных средах.

Например, анализ Фурье-образов неоднородных распределений намагниченности позволил обнаружить явление аморфизации бипериодических доменных структур в квазиодноосных магнитных пленках критической толщины [25], а также наличие фазовых переходов типа «чертова лестница» в магнитных пленках с модулированной структурой [26]. Не стоит сбрасывать со счетов и эстетический фактор: часто говорят о красоте фракталов [27], но красота их Фурье-образов впечатляет не меньше [28].

\section{2. ПОАУЧЕНИЕ ФУРЬЕ-ОБРАЗОВ КРИВЫХ И СНЕЖИНОК КОХА}

Нами Аля получения Фурье-образов применялся численный алгоритм, суть которого сводится к следующему. Изображения исследуемых фракталов аппроксимировацись сеточной функцией на равномерной сетке с ячейками, Аостаточно мелкими Аля алекватной передачи деталей предфракталов высоких поколений. Аля оцифрованного таким образом изображения с помощью быстрого преобразования Фурье определялись значения квадрата модулей Фурье-компонент, то есть спектральное распределение интенсивности Аифракционных максимумов $I$ в зоне Фраунгофера. А^я отображения интенсивности на плоскости использовацось представление значений $I$ в виде кругов с пропорциональным могарифму интенсивности радиусом, где коэффициент пропорциональности выбирался из соображений получения оптимальной наглядности получаемых изображений. С этой же целью Аополнительно применялось гауссово размытие отображающих кругов.

Изложенная выше процедура определения Фурье-образов, впервые описанная и примененная нами [29] Аля изучения фракталоподобных доменных структур в непрозрачных магнитных пленках (cм. [30-32]), позже была изложена в общедоступной периодике [25] и опробована на тестовых объектах (монопериодические и бипериодические доменные структуры в прозрачных магнитных пленках), когда эти объекты и создаваемые ими дифракционные картины можно было наблюдать визуально в режиме «на просвет» и фотографировать [25, 26]. По оцифрованным изображениям были получены Фурье-образы Аля многих плоских геометрических и алгебраических фракталов: ковер Серпинского, H-фракталы, кривые Пеано, 
бифракталы, фракталы L-системы, множества Мандельброта [28, 32, 33-35].

В Аанной работе численными методами было выполнено исследование свойств Фурье-образов семейства плоских триадных геометрических предфракталов поколений $N_{g} \leq 8$ с генератором в виде симметричной четырехзвенной Аоманой с произвольным углом $0^{\circ}<\alpha<180^{\circ}$ при вершине межАу центральными звеньями (рис. 1а) и с инициатором в виде отрезка прямой с Алиной $L$ (кривая Коха) или в виде равностороннего треугольника (снежинка Коха) с Алиной сторон $L$ (рис. 1b). Аля сохранения самоподобия преАфракталов при итерациях все звенья генератора Аолжны иметь Алину $L / 3^{N_{g}}$. В качестве примера на рис. 1с приведен вид предфракталов Коха второго поколения. При $\alpha \rightarrow 0^{\circ}$ моманаягенератор становится Аельта-образной, при $\alpha \rightarrow 180^{\circ}$ сливается с прямой-инициатором; случай $\alpha=60^{\circ}$ соответствует классической кривой Коха.

Анализ Фурье-образов показал, что при значениях $\alpha=180^{\circ} / k_{\alpha}$ или $\gamma=\left(90^{\circ}-\alpha / 2\right)=180^{\circ} / k_{,}$, где $k_{\alpha}$ и $k_{\gamma}-\Lambda$ юбые целые числа, они напоминают образы, присущие как илеальным кристаллам с осями симметрии 2-го, 3-го, 4-го и 6-го порядка, так и паркетным мозаикам [36] или

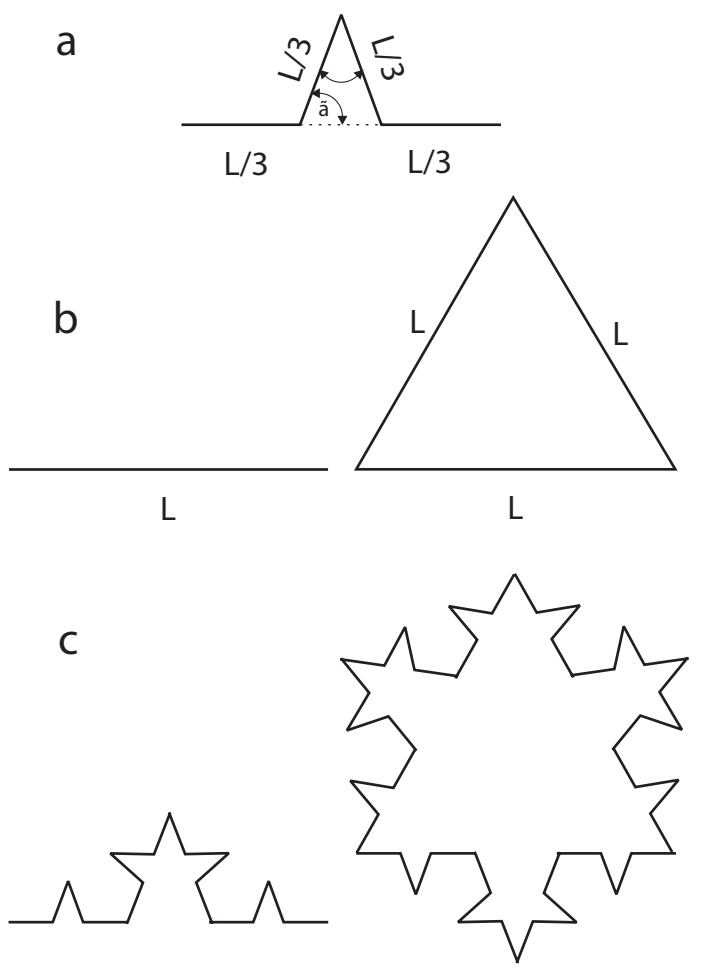

Рис. 1. Генератор (а), инициаторьг (b) и предфрактальг 2-го поколения для кривой и снежинки Коха (c).

квазикристальам [37] с осями квазисимметрии Аюбого порядка. Реально в Фурье-образах кривых Коха с инициатором в виде отрезка прямой наблюдались оси квазисимметрии с 3-го до 9-го и 11-го порядка. Получить качественный Фурье-образ с осью квазисимметрии 10- го порядка не удалось; причина этого будет обсуждена Аалее. Аля целочисленных значений $k_{\alpha}$ отчетливо проявАялись только оси квазисимметрии нечетного порядка (с 3-го по 11-ый вкАючительно), в то время как Аля целочисленных значений $k_{\gamma}-$ мюбые оси с порядком в интервале от 3 до 9. На рис. 2 представлены Фурье-образы Аля предфракталов кривых Коха 6-го поколения при $\alpha=36^{\circ}-(a)$, $\alpha=25.743^{\circ}-(b), \alpha=20^{\circ}-(c), \alpha=16.2637^{\circ}-(d)$.

\section{3. КОНФИГУРАЦИЯ И СИММЕТРИЯ ФУРЬЕ-ОБРАЗОВ}

Конфигурацию наблюдаемых Фурье-образов можно приближенно считать радиальнокольцевой, причем, как впервые было отмечено авторами работы [17] на примере классической снежинки Коха, в периферической («решеточной») части изображений доминирует радиальный характер с периодичностью распределения Аифракционных рефлексов по радиусу, а в центральной («фрактальной»)

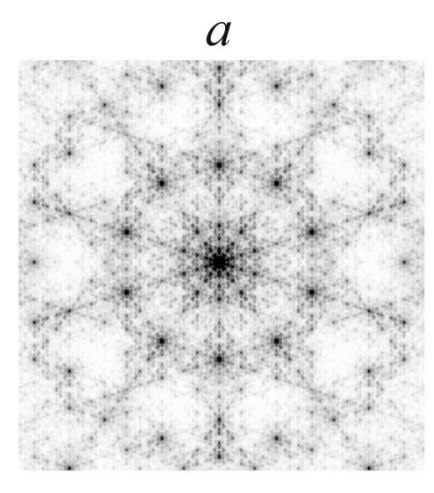

$c$
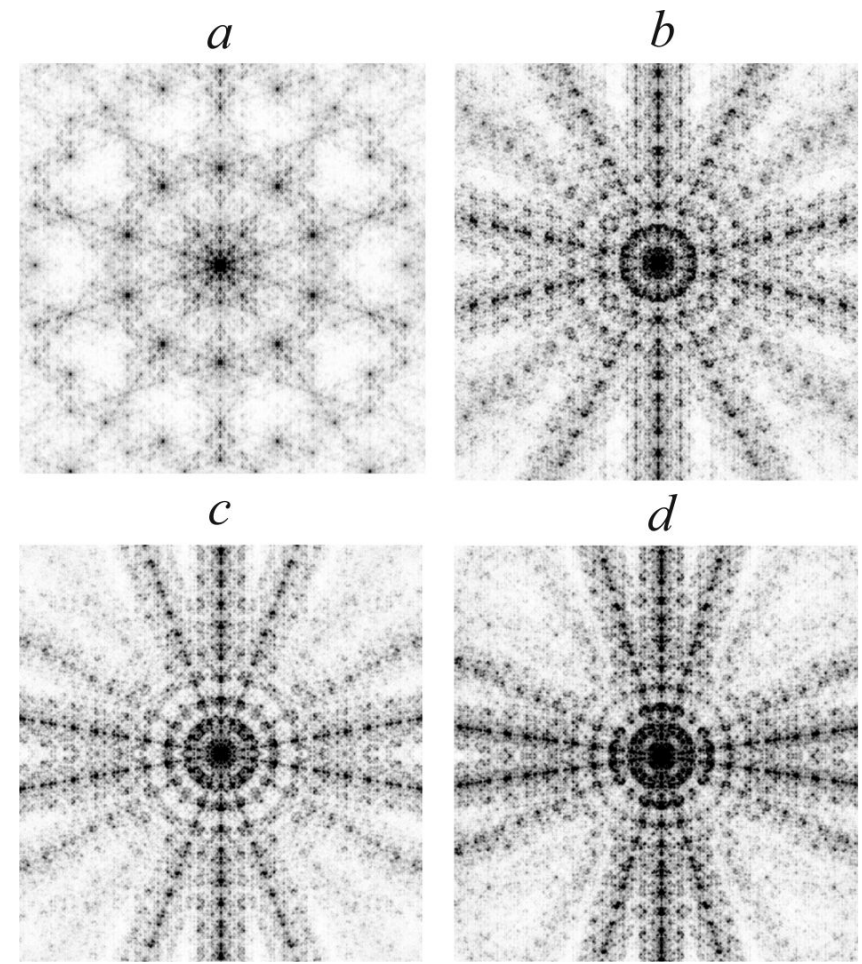

d

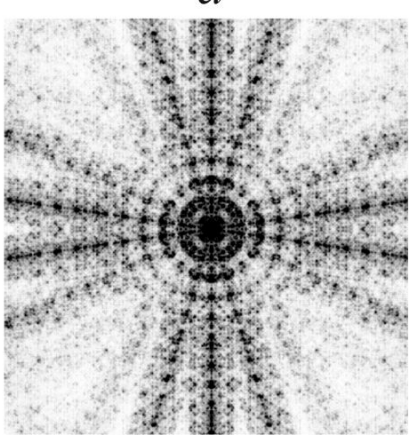

Рис. 2. Фурве-образы для предфракталов кривыгх Коха сосями квазисимметрии 5-го (a), 7-го (b), 9-го (c) и 11-го (d) порядка. 
- кольцевой с самоподобием. Было установлено, что диаметр центральной области после кажАой итерации возрастает в $m$ раз, гАе $\mathrm{m}=2[1+\sin (\alpha / 2)]$ - коэффициент масштабирования Аля рассматриваемых фракталов.

Решеточная часть наблюдаемых Фурьеобразов обладает своеобразной кластеризацией: все кучи имеют ярко выраженную центральную цепочку рефлексов вАОль раАиусов и паралмельные ей более слабые сателмиты по обе стороны (см. рис. 2b-d. Аналогичные черты прослеживаются также и на рис. 3, где показаны Фурье-образы предфракталов кривых Коха 6-го $(a)$, 5-го (b) и 4-го (c-d $)$ поколений Аля значений $k_{\gamma}=3,4,6$ и 8 .

Bce Фурье-образы обладали центром симметрии, который явАяется неотъемлемым атрибутом Аифракционных картин в зоне Фраунгофера Аля нецентросимметричных объектов (см., напр. [38]), однако вращательная симметрия не была илеальной: при повороте изображений вокруг оси порядка $k_{\alpha}$ на углы, кратные $180^{\circ} / k_{\alpha}$, совпаАали только положения Аифракционных рефлексов, а их интенсивности могли различаться. Наблюдалось частичное (см. рис. 2b) или полное (см. рис. 2c-d) ослабление
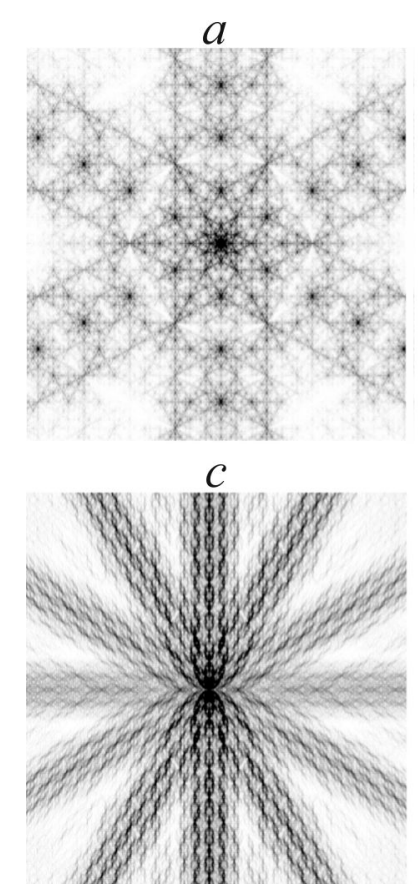

Рис. 3. Фурье-образы для предфракталов кривых Коха с осами квазисимметрии 3-го (a), 4-го (b), 6-го (c) и 8-го (d) порядка. интенсивности рефлексов вАОАь части кучей (аналог погасания узАов обратной решетки в рентгеноструктурном анализе [39]).

Причина наблюдаемых особенностей заключается в том, что рассматриваемые объекты, в отличие от кристаццов, преАставцяют собой не континуум точечных объектов (атомов), а Авумерное множество отрезков прямых, имеющих одинаковую Алину $L / 3^{N_{g}}$, но разную ориентацию в пространстве.

В этом множестве при целочисленных значениях $k_{\alpha}$ или $k_{\gamma}$ можно выделить состоящие из оАинаково ориентированных отрезков Авумерные подмножества, каждое из которых содержит некоторое количество парциальных одномерных Аифракционных решеток, образуемых расположенными вАоль оАной минии отрезками. Эти паралцельные решетки в общем случае содержат разное количество отрезков, причем степень заполнения и расстояния межАу сосеАними отрезками, определяющие интенсивность и характер распределения Аифракционных рефлексов вАОАь Аинии, зависят от ориентации решетки и номера поколения предфрактала $N_{\mathrm{g}}$.

Наличие в каждом из двумерных подмножеств из одинаково ориентированных отрезков совокупности нескольких разнесенных Аруг относительно Аруга параллельных одномерных решеток приводит к Авумерной Аифракционной картине с рефлексами не только вАОль решеток, но и по обе стороны от них (сатемлиты на рис. 2 и 4).

\section{4. СХЕМА ФОРМИРОВАНИЯ РЕШЕТОЧНОЙ И ФРАКТААЬНОЙ ЧАСТЕЙ ФУРЬЕ-ОБРАЗОВ}

Схему формирования решеточной части поясним на примере представленного на рис. 4 Фурье-образа предфрактала 4-го поколения с пентагональной квазисимметрией при $\alpha=36^{\circ}$. Цифрами 1-5 на изображении предфрактала помечены 5 типов ориентации отрезков; справа на врезке показаны возможные направления парциальных дифракционных решеток, слева на врезке - направления кучей (ср. с рис. 2). Количество парциальных решеток и степень их заполнения, зависят от номера поколения 


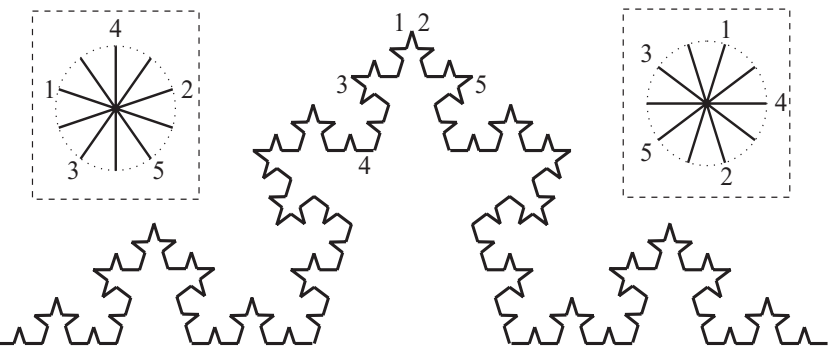

Рис. 4. Схема формирования решеточной части Фурье-образа с пентагональной квазисимметрией для предфрактала 4-го поколения с $а=36^{\circ}$.

предфрактала. Так, из рис. 4 следует, что число парциальных подрешеток в подмножестве с направ ением отрезков 1-го типа (см. правую врезку) равно 21, причем три из них содержат по 6, 7 и 8 отрезков, Аве - по 4, четыре - по 3, четыре - по 2 и восемь - по 1.

При значениях $\alpha=180^{\circ} / k_{\alpha}$ или $\gamma=180^{\circ} / k_{\gamma}$, где $k_{\alpha}$ и $k_{\gamma}-\Lambda$ юбые целые числа, количество возможных ориентаций отрезков $N_{\mathrm{s}}$ в предфрактале определяется номером поколения последнего g. При инициации существуют всего три допустимых ориентации, задаваемые генератором (рис. 1a), при кажАой последующей итерации добавляется еще Аве. В случае четных $k_{\alpha}$ или $k_{\gamma}$ на том шаге итерации, после которого не возникает отрезков с новыми ориентациями (то есть, при $N_{\mathrm{s}}=k_{\alpha}$ или $k_{\gamma}$, Аобавляется только один отрезок, ориентированный перпендикулярно инициатору. При последующих итерациях новых направлений отрезков уже не образуется.

Было обнаружено, что при четных значениях $k_{\alpha}$ существует $2 k_{\alpha}$ ориентаций отрезков, и, соответственно, $2 k_{\alpha}$ мучей в решеточной области Фурье-образа. Например, при $\alpha=22.5^{\circ}$ вместо 8 мучей образуется 16. Некоторые из мучей нам наблюдать не удацось из-за слабой заселенности соответствующих парциальных подрешеток Ааже в предфракталах максимально доступных (по техническим причинам) поколений. По тем же причинам потерпели неудачу попытки получить качественный Фурье-образ с Аексагональной квазисимметрией.

Сходные описанным выше свойства присущи также и Фурье-образам снежинок Коха (с инициатором в виде равностороннего треугольника), представленным на рис. 5 Аля некоторых предфракталов 6-го поколения при значениях $\alpha=120^{\circ}-(a), \alpha=22.5^{\circ}-(b), \alpha=30^{\circ}$
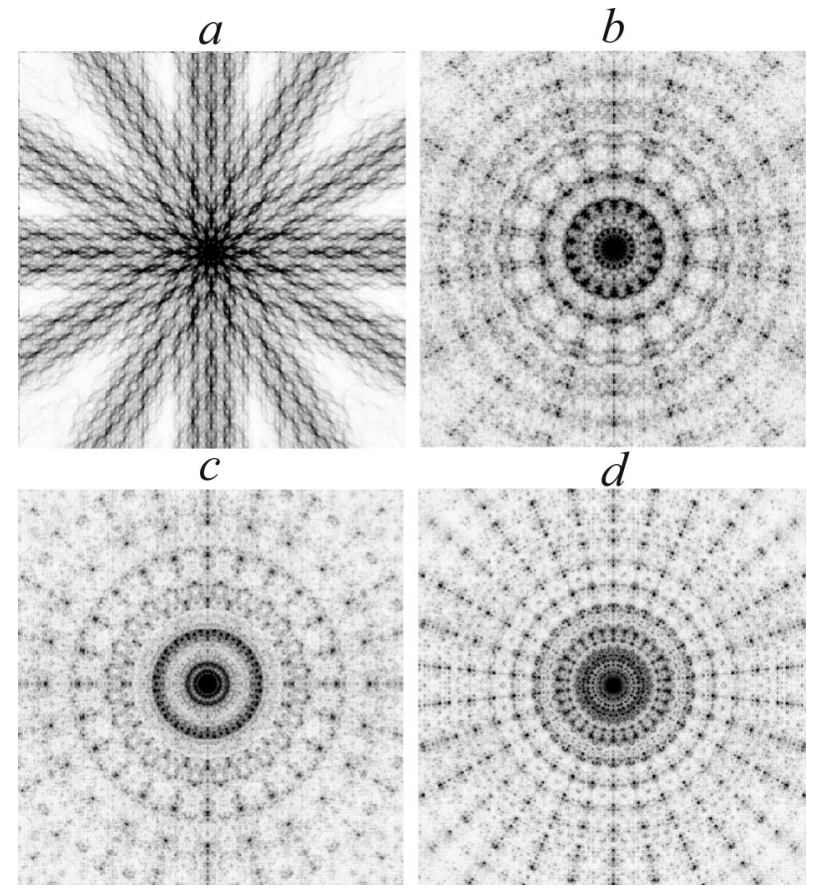

Рис. 5. Фурье-образы для предфракталов снежинок Коха с осями квазисимметрии 6-го (a), 9-го (b), 12-го (c) и 15-го (d) порядка.

$-(c)$, и $\alpha=12^{\circ}-(d)$. Заметим, что получаемые в Аанном случае Фурье-образы не яв яяются простым наложением образов от трех сторон сторон треугольника-инициатора, поскольку при дифракции суммируются волны с учетом разности фаз межАу ними.

Как следует из рис. 5, использование в качестве инициатора треугольника значительно увеличивает заполнение парциальных подрешеток и практически устраняет разАичие интенсивности Аифракционных пятен в симметрийно эквивалентных позициях во всех мучах решеточной части Фурье-образа. Кроме того, в Фурье-образах снежинок Коха более четко прослеживается разАичие структуры центральной и периферической частей. ВиАно, например, что квазисимметрия высоких поряАков в центраАьной части проявцяется в виде расположенных на концентрических окружностях изолированных пятен.

Обладающая самоподобием фрактальная часть, размер которой возрастает с увеличением угла $\alpha$ (припрочихравныхусловиях), формируется суммой центральных дифракционных масимумов от всех элементов фрактала. При $L \rightarrow \infty$ и $N_{\mathrm{g}} \rightarrow \infty$ исчезает решеточный вклаА в Фурье-образ, так как во-первых, стремится к нулю расстояние межлу образующими решетки 
отрезками и, во-вторых, эти отрезки переходят в точки, Аифракционная картина от которых обладает радиальной симметрией.

\section{5. ЗАКАЮЧЕНИЕ}

Приведенные результаты убедительно свидетельствуютотом, чтообобщенныетриадные предфракталы Коха достаточно высоких поколений при определенных условиях могут обладать Фурье-образамисосямиквазисимметрии Аюбого порядка подобно паркетным мозаикам [36] или квазикристалмам [37]. В настоящее время имеются сведения о реализации мозаик с порядком оси квазисимметрии 5, 8, 10 и 12; квазикристалмы помимо перечисленных могут иметь ось квазисимметрии 7-го порядка [40, 41]. УАивительным при этом явАяется тот факт, что в отАичие от мозаик и квазикристалАов кривые Коха вообще мишены поворотных осей симметрии, а снежинки Коха имеют единственную ось симметрии 3-го порядка.

Тем не менее, уже Аавно межАу фракталами и паркетными мозаиками, а позже и квазикристальами, были замечены некие родственные связи, в установлении которых, повидимому,решающуюроль сыгралосамоподобие $[40,42]$. И как аксиомы воспринимаются сейчас утверждения о том, что мозаики явцяются Авумерными аналогами квазикристалмов, а послеАним при Аюбой квазисимметрии можно поставить в соответствие сопутствующие им фрактальные структуры [43, 44]. Методы фрактальной геометрии применяются А^я описания моделей квазикристаллических структур, а Аревесно-графовая процедура используется Аля их порожАения $[44,45]$.

C точки зрения абстрактной ацгебры апериодические структуры (квазикристалмы и мозаики), в отличие от описываемых группами илеальных кристал^ов, описываются алгебраическими системами типа «поле», которые могут облаАать вращательной симметрией и фрактальным упорядочением [46]. А^я описания геометрических фракталов используют аАгоритмы так называемой L-системы [47].

\section{МИТЕРАТУРА}

1. Мандельброт ББ. Фрактальная геометрия природъъ. М., Институт компьютерных исследований, 2002, 656 с.

2. Олемской АИ, ФАат АЯ. Использование концепции фрактала в физике конденсированной среды. УФН, 1993, 163(12):1-50.

3. Gouyet J-F. Physics and fractal structures. Paris, Ecole Polytechnique, 1995, $234 \mathrm{p}$.

4. Peitgen H-O, Jürgens H, Saupe D. Chaos and fractals. New frontiers of science. New York, Springer-Verlag, 2004, 864 p.

5. Levy-Vehel J, Lutton E. Fractals in Engineering. London, Springer-Verlag, 2005, 290 p.

6. Потапов АА. Фрактальг в радиофизике ирадиолокачии. M., Аогос, 2002, 664 c.

7. Fractals in Biology and Medicine: vol. IV (Mathematics and Biosciences in Interaction). ed. by Losa GA, Merlini D, Nonnenmacher TF,.Weibel ER. Basel, Birkhaüser, 2005, 314 p.

8. Мандельброт ББ, Хадсон РА. (Не)послуиные рынки. Фрактальная ревалючия в финансах. Киев, Вильямс, 2006, 408 c.

9. Алмазов АА. Фрактальная теория. Как поменять взгляд на финансовыге ръгнки. Admiral Markets, М., 2009, 209 c.

10. Madden Ch. Fractals in Music: Introductory Mathematics for Musical Analysis. Salt Lake City, High Art Press, 1999, $224 \mathrm{p}$.

11. Бонч-Осмоловская ТБ. Введение в митературу формальных ограничений. Самара, Бахрах-М, 2009, $560 \mathrm{c.}$

12. Тарасенко ВВ. Фрактальная семиотика. Слепые пятна, перипетии и узнавания. М., Аиброком, 2009, 232 с.

13. Исаева ВВ, Касьянов НВ. Фрактальность природных и архитектурных форм. Вестник АВО PAH, 2006, 5:119-127.

14. ШАык ВА. Фракталы в абстрактном искусстве и Аизайне. Изв. Челябинского научного чентра УрО PAH, 2004, 1(22):231-244.

15. Classification and Application of Fractals: New Research. ed. by Mitchell EW, Murray SR. New York, October Nova, 2012, $347 \mathrm{p}$.

16. Alain C, Cloitre M. Optical diffraction on fractals. Phys. Rev. B, 1986, 33(5):3566-3569.

17. Uozumi J, Kimura H, Asakura T. Fraunhofer diffraction by Koch fractals. J. Mod. Optics, 1990, 37(6):1011-1031.

18. Sakurada Y, Uozumi J, Asakura T. Diffraction Fields of Fractally Bounded Apertures. Opt. rev., 1994, 1(1):3-7.

19. Uozumi J, Kimura H, Asakura T. Fraunhofer diffraction by Koch fractals: the dimensionality. J. Mod. Optics, 1991, 38(7):1335-1347.

20. Sakurada Y, Uozumi J, Asakura T. Fresnel diffraction by $1 \mathrm{D}$ regular fractals. J. Optics. A: Pure Appl.Optics, 1992, 1:29-40.

21. Chabassier G, Angéli B, Heliodore F, Le Mehauté A. 
Optical wave diffraction on fractal objects. J. Optics. A: Pure Appl.Optics, 1992, 1:41-54.

22. Bo Hou, Gu Xu, Wen W, Wong GK L. Diffraction by an optical fractal grating. Appl. Phys. Lett., 2004, 85(25):6125-6127.

23. Funamizu H, Uozumi J. Generation of fractal speckles by means of a spatial light modulator. J. Opt. Soc. of Amer:: Opt. Express, 2007, 15(12):7415-7422.

24. Horváth P, Śmid P, Vásková I, Hrabovský M. Koch fractals in physical optics and their Fraunhofer diffraction patterns. Optik, 2010, 121(2):206-213.

25. Арзамасцева ГВ, Евтихов МГ, Аисовский ФВ, Мансветова ЕГ. Темирязева МП. Аморфизация бипериодических Аоменных структур в квазиодноосных магнитных пленках критической толщины. ЖЭТФ, 2008, 134(2):282-290.

26. Арзамасцева ГВ, Евтихов МГ, Аисовский ФВ, Мансветова ЕГ. Спонтанные фазовые переходы в магнитных пленках с модулированной структурой. ЖЭТФ, 2011, 140(3):516-526.

27. Пайтген Х.-О, Рихтер ПХ. Красота фракталов. Образы комплексных динамических систем. М., Мир, 1993, 206 c.

28. Арзамасцева ГВ, Евтихов МГ, Аисовский ФВ, Мансветова ЕГ. Фурье-образы фрактальных объектов.Изв. РАН, сер.физ., 2010, 74(10):1430-1432.

29. Арзамасцева ГВ, Евтихов МГ, Аисовский ФВ, Аукашенко А.И. Компьютерное моделирование Аифракции света на фрактальных доменных структурах. Тр. XIX Междунар. иколь-семинара "Новые магнитные материалы микроэлектроники", МГУ, Москва, 2004: 632-634.

30. Аикштейн ИЕ, Кузнецов $\triangle \mathrm{B}$, Аисовский $Ф \mathrm{~B}$, Мансветова ЕГ. Тр. ХVI Межуунар. школь-семинара "Новые магнитные материаль микроэлектроники" ч. II, УРСС, Москва, 1998:519.

31. Аисовский $Ф В$, Мансветова ЕГ, Аукашенко $\Lambda$ И. Фрактальные Аоменные структуры в пермалмоевых пленках. Тр. XIX Междунар. иколь-семинара "Новъге магнитныле материаль микроэлектроники", МГУ, Москва, 2004, с. 838-840.

32. Аисовский $Ф \mathrm{~B}$, Аукашенко $\Lambda$, Мансветова ЕГ. Термодинамически устойчивые фракталоподобные доменные структуры в магнитных пленках. Писъма в ЖЭТФ, 2004, 79(7):432-435.

33. Арзамасцева ГВ, Евтихов МГ, Аисовский ФВ, Мансветова ЕГ. Компьютерное моделирование мультиплицирования фурье-спектров предфракталов L-системы. Электромагнитные волны и электронные системыл, 2012, 17(12):29-32.

34. Арзамасцева ГВ., Евтихов МГ, Аисовский ФВ., Мансветова ЕГ. Компьютерное моделирование Аифракции Фраунгофера на Н-фракталах и кривых Пеано. Электромагнитные волны и электронные системьг, 2012, 17(7):48-58.

35. Арзамасцева ГВ, Евтихов МГ, Аисовский ФВ, Мансветова ЕГ. Свойства плоских геометрических бифракталов. Радиоэлектроника. Наносистемьл. Информачионнье техналогии, 2012, 4(2): 93-107.

36. Penrose R. Pentaplexity: A class of non-periodic tilings of the plane. Eureka (Cambridge), 1978, 39:16-22.

37. Shechtman D, Blech LA, Gratias D, Cahn JW. Metallic phase with long-range orientational order and no translational symmetry. Phys. Rev. Lett., 1984, 53(20):1951-1953.

38. Гехт Э. Свойства симметрии в картинах Аифракции Фраунгофера. УФН, 1973, 111(2): 355-364.

39. Уманский ЯС, Скаков ЮА, Иванов АМ, Расторгуев $\Lambda$ Н. Кристаллография, рентгенография и электронная микроскопия. М., Металмургия, 1982, 632 с.

40. Suck J-B, Schreiber M, Haussler P. Quasicrystals: an introduction to structure, physical properties, and applications. Berlin-Heidelberg, Springer Verlag, 2010, 564 p.

41. Мильман ЮВ, Ефимов НА, Гончарова ИВ. Квазикристалмы - новый класс твердых тел с уникальными физическими свойствами. Сб. научн. mр. Ин-та проблем материаловедения НАН Украинь, 2012, 18: 3-14.

42. Гарднер М. От мозаик Пенроуза к надежныгм шифрам. М., Мир, 1993, 416 с.

43. Аазарев АИ, Аомрачев ГА. Ромб́ и квацрат как зародыши Аля фрактального построения Авумерных квазикристалмических структур с вращательной симметрией 8-го и 4-го порядков. Кристаллография, 1994, 39(5): 811-844.

44. ЮАин ВВ, Карыгина ЮА. Фракталъность квазикристалцов на примере мозаики Пенроуза. Кристаллография, 2001, 46(6): 1004-1008.

45. Аазарев АИ, Суханов АЮ, Аомрачев ГА. Устойчивые фрактальные формы в плоских квазикристал^ических структурах с симметрией 8-го, 4-го, 2 го и 1-го порядков, имеющих коэффициент самоподобия. Кристаллография, 1996, 41(5):798-803.

46. Аомрачев ГА, Аазарев АИ. Приложение теории алгебраических систем Аля созАания иерархии структур твердых тел, образующихся при равновесных и неравновесных условиях. ФТТ, 1999, 41(5): 799804.

47. Lindenmayer A. Mathematical models for cellular interaction in development. J. Theoret. Biology, 1968, 18:280-315. 
Арзамасцева Гамина Васимьевна

К.ф.-м.н., с.н.с.

ФИРЭ им. В.А. Котельникова РАН

1, пл. Введенского, 141190 Фрязино Моск. обл. arzamastseva@mail.ru

Евтихов Михаим Григорьевич

К.ф.-м.н., с.н.с.

ФИРЭ им. В.А. Котельникова РАН

1, пц. Введенского, 141190 Фрязино Моск. обл.

emg20022002@mail.ru
Мисовский ФеАор Викторович

д.ф.-м.н., проф., гл.н.с.

ФИРЭ им. В.А. Котельникова РАН

1, пи. Введенского, 141190 Фрязино Моск. обл. lisf@df.ru

Мансветова Екатерина Георгиевна

к.ф.-м.н., с.н.c.

ФИРЭ им. В.А. Котельникова РАН

1, пи. Введенского, 141190 Фрязино Моск. обл.

mansvetova_eg@mail.ru

\title{
FOIRIER IMAGES QUASISYMMETRY OF GENERALIZED TRIADIC KOCH PREFRACTALS
}

\author{
${ }^{1,2}$ Galina V. Arzamastseva, ${ }^{1}$ Mikhail G. Evtikhov, ${ }^{1}$ Feodor V. Lisovsky, ${ }^{1}$ Ekaterina G. Mansvetova \\ ${ }^{1}$ Kotel 'nikov Institute of Radioengineering and Electronics, Fryazino Branch, Russian Academy of Sciences, http:/ fire.relarn.ru \\ 1, Vvedensky sq., 141120 Fryazino, Moscow region, Russian Federation \\ ${ }^{2}$ Modern University for the Humanities, http://www.muh.ru/ \\ 32/4, Nizhegorodskaya str., 109029 Moscow, Russian Federation \\ arzamastseva@mail.ru, emg20022002@mail.ru, lisf@df.ru, mansvetova_eg@mail.ru
}

Abstract. The study of the Fourier-images properties was made by numerical methods for the family of flat triadic geometric prefractals with generator in the form of symmetric four-stage broken line with an arbitrary angle at the apex between the central units and the initiator in the form of a straight line (Koch curve) or in the form of an equilateral triangle (the Koch snowflake). To obtain the Fourier images the pictures of fractals were approximated by a grid function on a uniform grid with cells small enough for adequate mapping of high generation prefractal details, and then were digitized in order to use fast Fourier transform for determination the values of the squared modules of the Fourier component, that is, the spectral intensity distribution of diffraction maxima in the Fraunhofer region. An analysis showed that for the values of the vertex or base angles equal to the integer fraction of 180 degrees, Fourier images are the same as for the perfect crystals with the symmetry axes of the 2-nd, 3-th, 4-th and 6-th order, or as for parcuet mosaics or quasicrystals with the axes of quasisymmetry of any order. Really in the Fourier images of the Koch curves with the initiator in the form of a straight line was observed axis of quasisymmetry from 3rd to 9 th and 11-th order. Similar to the above-described properties are also inherent to Fourier images of the Koch snowflake with the initiator in the form of an equilateral triangle. The configuration of the observed Fourier images can be approximately regarded as a radial-annular, at that in the peripheral ("lattice") of the images is dominated by the radial nature of the frequency distribution of diffraction reflections along the radius, and in the central ("fractal") - a ring with self-similarity. The lattice part has a kind of clustering: all the rays have a strong central chain of reflexes along the radii and parallel to it the weaker satellites on both sides. All Fourier images had the center of symmetry, which is an integral attribute of the diffraction patterns in the Fraunhofer zone for any objects, however, the rotational symmetry was not perfect: the positions of the diffraction reflexes when rotating images at angles that correspond to the order of the symmetry axis remain unchanged, but their intensity could vary. The cause of the observed features is that prefractals, unlike crystals, are not a continuum of point objects but two-dimensional set of equal length line segments with different orientation in space. In this set for the considered configurations of the generator it is possible to allocate several two-dimensional subsets with equally oriented segments, each of which contains a number of partial one-dimensional diffraction gratings formed by segments located along the same line. These parallel lattice in the general case contain a different number of segments, and the degree of filling and the distance between adjacent segments, determining the intensity and diffraction reflections distribution structure along the line, depend on the orientation of the lattice and the generation number of prefractal.

Keywords: digital methods, Fourier image, Fraunhofer diffraction, generator, initiator, Koch curve, Koch fractal, Koch snowflake, parquet mosaic, prefractal, quasiqristal, quasisymmetry, scaling invariance, selfsimilarity, symmetry.

UDC 51.74; 535.42 


\section{ЭВОАЮЦИОННЫЕ АСПЕКТЫ ПОЯВАЕНИЯ ГЕАЯ И ЕГО ФУНКЦИЙ В ЦИТОПААЗМЕ КАЕТОК}

\section{3арицкий А.Р., ${ }^{2}$ Грачев В.И., ${ }^{1}$ Зайцева Г.В., ${ }^{1}$ Кириченко М.Н.}

${ }^{1}$ Физический институт им. П.Н. Аебедева, Российская академия наук, http:/ /www.lebedev.ru 119991 Москва, Российская Федерация

${ }^{2}$ Институт радиотехники и электроники им. В.А. Котельникова, Российская академия наук, http:/ /www.cplire.ru 125009 Москва, Российская Федерация

Поступила 16.11.2016

В работе рассмотрен известный феномен в жизнедеятельности и эволюционном развитии животных клеток - наличие в их цитоплазме геля. Описана эволюция появления геля с Аинамикой фазовых переходов золь-гель. Обоснована основная функция гемя в цитоплазме - обеспечение интенсификации энергетического метаболизма киеток. Показана роль геля в инфраструктуре клетки и ее компартментов, взаимосвязь геля ицитоскелета, способствующая трансмембранному обмену клетки с окружающей средой. Показана также роль гелевых каналов в могистике водных потоков и активных веществ в цитопмазме, в регумяции механизмов метаболизма клеток, в частности, режимов обезвоживания цитоплазмы спорообразования в одноклеточных организмах и высыхания кожных покровов человека как в норме, так и при размичных патомогиях.

Ключевые слова: цитопмазма, золь, гель, структурированная вода, энергетический метаболизм, цитоскелет, гелевые каналы, водные потоки, механизмы обезвоживания

\section{PACS: 87.23.KG}

\section{СоДЕРЖАНИЕ}

1. ВВеАЕНИЕ (215)

2. ЭВОАЮЦИОННЫЕ АСПЕКТЫ ПОЯВАЕНИЯ ГЕАЯ В ЦИТОПААЗМЕ КАЕТОК (217)

3. ЭВОАЮЦИЯ ИНТЕНСИФИКАЦИИ ГЕАЕМ ЭНЕРГЕТИЧЕСКОГО МЕТАБОАИЗМА КАЕТОК (218)

4. РОАЬ ГЕАЯ В ЭВОАЮЦИИ ЦИТОСКЕАЕТА (219)

5. ГЕАЕВЫЕ ТРАНСПОРТНЫЕ СТРУКТУРЫ В ЦИТОПААЗМЕ (219)

6. ГЕАЬ КАК СРЕАСТВО ОБЕЗВОЖИВАНИЯ ЦИТОПААЗМЫ (220)

7. ЗАКАЮЧЕНИЕ (221)

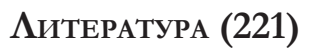

\section{1. ВВЕАЕНИЕ}

Внутренняя среАа живой клетки - протоплазма явАяется предметом интенсивных исследований современной цитофизиологии. Еще соратник Чарльза Аарвина Томас Г. Гексли полтора века назаА назвал протоплазму физической основой жизни [1]. Американский цитолог Аевис В. Гейльбрун [2] утвержАац, что “если мы сумеем расшифровать тайны жизни и механизмы жизнедеятельности, то только путем изучения протоплазмы”. Внеядерная часть протоплазмы - цитоплазма клеток и ее жилкая фракция (без органоилов-органели и метаболитов) цитозоль изучены до сих пор недостаточно [3-5]. Использование нелинейных методов анализа, новых спектроскопических, ЯМР и Аругих технологий и современного компьютерного анализа позволяют реализовать как количественные, так и новые качественные подходы к их проблемам. К настоящему времени известно, что цитозоль разбитый на несколько отсеков-компартментов разнообразными мембранами колмоилный растворбелков, ферментов, углеводов, Аипидов, низкомолекулярных (меньше 300 Аа и 1 нм [6]) соединений и неорганических солей в воде с $\mathrm{pH}$ от 7.0 Ао 7.4 [7], с асимметрией распределения ионов в цитозоле и вне клетки $\left(K^{+}{ }_{\text {in }} / K^{+}{ }_{\text {ex }}=\right.$ $139 / 4 \mathrm{mM}, \mathrm{Na}^{+}{ }_{\text {in }} / \mathrm{Na}_{\text {ex }}^{+}=12 / 145 \mathrm{mM}$, и т.А.[3]), метаболитов, с концентрацией небелковых молекул такой, что скорость их Аиффузии изза столкновений в 4 раза меньше, чем в чистой воде [8]. Механизм образования градиентов их концентраций также мало изучен [9]. В состав цитозоля входят также рибосомы нуклеопротеилы, синтезирующие белки. 
Белки цитозоля занимают до 30\% его объема [10], до 10 милииардов белковых молекул около 10 тысяч разных типов на клетку [11]. Они находятся в состоянии непрерывных процессов синтеза и распада. Свободные глобулярные и менточные фибримлярные белки образуют колмоилные растворы в воде, которая занимает Ао 70\% объема цитозоля [12]. При высокой концентрации макромолекул цитозольная вода находится в связанном с макромолекулами состоянии [13, 14]. При этом колмоиАный раствор может быть Аибо невязким золем, Аибо вязким, желеобразным гелем.

Золь (от кат. solutio - раствор) высокодисперсный колмоилный раствор с жидкой Аисперсионной средой, в объеме которой распределена Аисперсная фаза органических веществ и ионов - броуновских частиц размером $10^{-7}-10^{-9}$ м [3], не связанных в пространственную структуру. При этом клетка находится в активном состоянии. При коагуляции, агрегировании дисперсных частиц золя происходит фазовый перехоА золя в гель.

Гель (от лат. gelo - застываю) структурированная система из трехмерной макромолекулярной сетки (каркаса), заполненной низкомолекулярным растворителем Аисперсионной средой, в клетке - водой. В работах Гильберта Н. Аинга [13] и Ажеральда Х. Помлака [14] показано, что в компартментах цитоплазмы при аАсорбции активным белком (например, миозином в мышечном волокне) АТФ, ионов и мономера актина солевые связи белка рвутся, его вторичная свернутая структура разворачивается в паралмельно ориентированную цепь, чьи карбоксильные группы сорбируют $K^{+}$и на полярных аминогруппах $\mathrm{NH}^{-}$и карбонильных $\mathrm{CO}$-группах пептидного остова уже полноразвернутого белка слой за слоем сорбируется ориентированная и поляризованная (с увеличенным Аипольным моментом) вода - гель, т.е. связанная и структурированная нерастворяющая вода на неглобулярном Аинейном белке (рис. 1). Многослойная водная структура геля Аинамична, ее молекулы постоянно перемещаются,

меняются

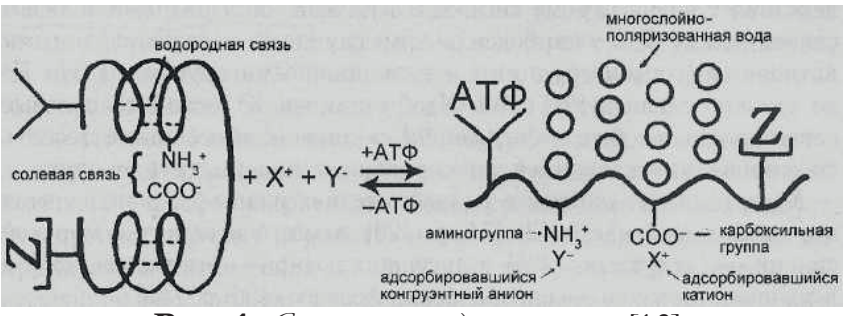

Рис. 1. Схема переходов золь-гель [13].

местами, но все Авижения в ней ограничены, взаимодействия межАу ними сильнее, чем в обычной воде, структура как целое устойчива и не смешивается со свободной водой клетки, которая практически отсутствует, т.к. почти вся вода клетки включена в упорядоченные слои белково-ионо-водного комплекса. При этом клетка находится в состоянии покоя.

Высокоэнергетический, низкоэнтропийный гель термодинамически неустойчив: гидролиз АТФ приводит к перераспределению электронной плотности в молекуле белка, его конформация меняется, его аминокислотные группы становятся недоступны воде, структурная сетка самопроизвольно разрушается с выделением жилкой фазы, восстановленные солевые связи сворачивают базовую менту белка в глобулу, - гель переходит в 3оль, жиАкий колАоиАный раствор.

Колмоилный раствор белков клетки находится в состоянии постоянных фазовых переходов первого рода золь-гель - гель-золь [15] за счет энергии АТФ, синтезируемой как в цитозоле, так и в рибосомах клетки. Эти переходы - нелинейные колебания с постоянно изменяющимся, варьирующим периодом. Аиапазон периодичности или ритмов этих фазовых переходов (ритмов агрегации) - от $10^{-10}$ сек до секундных, минутных, око оочасовых и т.А. вПлоть АО сезонных и годовых. Эти переходы вызываются различными факторами - космогелиогеофизическими, согласованием ритмов межАу сосеАними компартментами, изменением $\mathrm{pH}$, водно-солевого режима и т.А., и обеспечивают Аинамику процессов метаболизма и аАаптации всех жизненно важных циклов в клетке.

Несмотря на интенсивные исследования последнего времени воды и водных колАоиАОв живой клетки (см., напр., [16-20] и мн. Ар.), 
эволюционный аспект в этих исслеАОваниях остается без особого внимания. В настоящей работе именно этот аспект явцяется основным предметом исследования.

\section{2. ЭВОАЮЦИОННЫЕ АСПЕКТЫ ПОЯВАЕНИЯ ГЕАЯ В ЦИТОПААЗМЕ КАЕТОК}

На завершающем этапе абиогенеза (вероятный его вариант), при переходе первых на Земле устойчивых обособленных источников свободной энергии - углеводородных нанокапель аэрозоля с открытым метаболизмом и формирующейся абиогенной органики из планетарного автоклава безкислородной приповерхностной атмосферы в водную среду первичной гидросферы остывающей планеты, - мипилы и архаичные ферменты с поверхности капель формировали на турбулентной границе раздела атмосферы и водной поверхности мипидные везикулы (Аат. vesicula - пузырёк), содержащие водный раствор углеродсодержащих соединений, архаичных ферментов, вирусов и рибонуклеотилов с унаследованными от углеводородных капель механизмами анаэробного метаболизма $[21,22]$. Анаэробное усвоение глюкозы и ее полимера гликогена из окружающей вОАной среды оказалось Аостаточной энергетической основой метаболической активности везикул вплоть до митоза. В работах [23-25] выяв еен ведущий физический фактор молекулярных механизмов режимов активности и митоза изменение кислотности внутренней среды везикулы, определяющее порядок смены процессов и явлений при Аелении везикул и смены режимов их метаболизма. Максимально возможная мощность групп метаболических процессов, конкурирующих за макроэрги в везикулах, Аостига^ась разведением этих групп во времени путем естественного закисления внутренней среды при синтезе макроэргов и принудительном ее подщелачивании при их утилизации. Цикличность режимов метаболизма везикул сформировалась отбором ферментов по активности катализа синтеза в области бо́льших значений $\mathrm{pH}$, чем катализа утилизации макроэргов. При Аостаточно высокой концентрации пептидов, полипептидных структур и АТФ вместе с ионами низкомолекулярной фракции в объеме везикулы в результате пино- и фагоцитоза из внешней среды и синтеза в среде внутренней водный раствор содержимого везикулы структурировался в колАоил с Аинамикой золь-гель переходов. Цикличность режимов метаболизма везикул определяла и ритм этих переходов. Жилкокристалмическая фаза геля - универсальный акцептор осмотических и механических, электромагнитных и гравитационных колебаний, который сохранил свою фундаментальную роль в эволюции и после появления специализированных рецепторных белков и иных рецепторных структур.

Естественным завершением такого развития стало появление первых простейших клетоканаэробов, безхромосомных и безядерных прокариот, способных к воспроизводству [25, 26]. Постепенное накопление в атмосфере кислорода обеспечило формирование и развитие у некоторой части везикул и анаэробов-прокариот метаболизма на основе фотосинтеза, т.е. метаболизма аэробного, что Аало нача^о развитию простейших прокариотаэробов. К моменту Аостижения в атмосфере парциального Аавления кислорода в 2 мм.рт. ст. (судя по гомеостазу уровня кислорода в цитоплазме современной животной клетки) и накопления кислорода в гидросфере везикулы и архаичные прокариоты со сложным метаболизмом, включающим фотосинтез и утилизацию энергоемких субстратов анаэробным и аэробным способом, вытеснили практически все Аругие везикулы и Аали старт формированию и развитию эукариотических (гр. karyon - ядро) клеток [25].

Комлоидные структуры компартментов эукариот, как и прокариот, оптимизировали всю кинетику метаболизма клеток посредством фазовых переходов золь-гель, генерирующих энергию в широком Аиапазоне спектра электромагнитных и акустических колебаний [27-29], чрезвычайно слабая интенсивность которых воспринималась на фоне тепловых шумов [30, 31], - эволюционно наиболее Аревнем, по-видимому, способе информационного взаимодействия 
биосистем. ААресные способы передачи информации возникли в ходе эволюции Аишь у многоклеточных организмов. Гель одних компартментов клетки может поглощать энергию сигналов, генерируемых при переходе золя в гель соседних компартментов клетки, переходя при этом в золь. Сверхслабые взаимодействия, определяющие эти процессы,

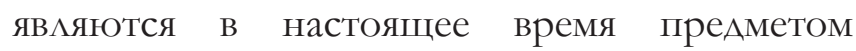
интенсивных исследований [32]. Фазовые переходы первого и второго рода определяются степенью синхронизации ритмов золь-гель переходов между соседними компартментами клетки и согласованием ритмов разных периодов. Исследование этих ритмов вносит свою мепту в формирование современных фундаментальных понятий проблемы биологического времени и времени вообще.

Таким образом появление в ходе эволюции геля в цитозоле явилось решающим фактором оптимизации всех процессов метаболизма в нарождающихся клеточных структурах.

\section{3. ЭВОАЮЦИЯ ИНТЕНСИФИКАЦИИ ГЕАЕМ ЭНЕРГЕТИЧЕСКОГО МЕТАБОАИЗМА КАЕТОК}

Наличие и рост электрического поля в цитомембранах в процессе эволюционных преобразований обеспечили в клетках неуклонный рост концентрации биологически активных веществ [33] и, как следствие, рост интенсивности их энергетического метаболизма. Аругим, не менее важным фактором, который использовала природа Аля той же цели, стал гель.

В п.2 был рассмотрен возможный вариант естественного появ $е$ ения геля во внутренней среде протоклеточных структур, а также биологическая целесообразность его функционирования в процессах их жизнедеятельности, проявцяющая себя в оптимизации всех процессов метаболизма клеток. Считая энергетический метаболизм ведущим видом метаболизма клетки и неуклонную его интенсификацию генерацьной Аинией эволюционного развития клеточного мира с самого начала его зарожАения, рассмотрим эволюционные аспекты участия в этом процессе белково-ионно-водного комплекса клетки, ее цитозоля, существующего в режиме непрерывного фазового перехода ЗО Аь-гель - гель-зО Аь.

Если на начальных стадиях зарождения протоклеточных структур, в первых мипилных везикулах «первобытного бульона» не существовало Аостаточного набора соединений и элементов А^я организации водных колАоиАных растворов необходимой концентрации, метаболизм которых позволял бы делать запасы энергоемких компонент, то с возникновением аэробных везикул и архаичных протокариотов Аостаточного размера с развитыми метаболическими механизмами процессы накопления энергетических запасов можно представить себе достаточно вероятными. В клетке появился постоянный фактор усиления метаболизма - гель. Т.к. цитозоль в состоянии геля практически обезвожен, Аоля свободной воды в золе минимальна. Соответственно максимальна в нем концентрация глобулярных белков, не участвующих в образовании геля. Их форма не позволяет структурировать воду на уровне размеров отдельных аминокислот в той же степени, что неглобулярные белки. Из-за наличия на поверхности глобул гицрофобных участков эти белки обладают низким сродством к уже сформированному гелю. Эти глобулярные белки золя непосредственно участвуют в клеточном метаболизме. При этом их концентрация, молекулярный вес и интенсивность метаболизма существенно возрастает, являясь неизбежным следствием разделения цитозоля на две фазы - золь и гель. Усиление метаболизма приводит в свою очередь к возникновению цепочки причинноследственных связей: росту концентрации АТФ в золе, ускорению работы $K^{+} / \mathrm{Na}^{+}$-АТФ-аз, усилению электрического поля в цитомембране, вызывающего асимметрию проницаемости Аипидных мембран Аля Аипольных соединений и, как следствие, увеличение потоков воды из клетки (эффект Чарахчьяна [33]). Эти потоки компенсируются увеличением осмотических потоков в цитоплазму, обусловленных ростом 
концентрации осмотических частиц в золе при формировании геля.

Таким образом, рост углеводородной массы и развитие механизмов метаболизма энергоемких соединений привело к разделению в процессе эволюции цитозоля клеток на золь и гель, что, в свою очередь, "взаимообразно" обеспечило постоянный рост интенсификации энергетического метаболизма клеток, т.е. следование генеральной минии эволюционного развития клеточного мира.

\section{4. РОАЬ ГЕАЯ В ЭВОАЮЦИИ ЦИТОСКЕАЕТА}

ОАним из прямых слеАствий интенсификации гелем внутриклеточного метаболизма явяляется активизация им формирования элементов цитоскелета в примембранных областях протоклеточных образований. Эволюционную цепочку в этом случае можно построить слеАующим образом. В везикулах и первых прокариотах вполне вероятен синтез супрамолекулярных, протяжных полимерных структур, состоящих из полипептилных мономеров одного типа, которые уже связывают воду и формируют, тем самым, гель. Вполне вероятен также синтез в цитоплазме первичных структур актино- и тубулиноподобных по аминокислотам протофиламентов. В фазе гелеобразования оставшийся золь собирает эти структуры под мембраной по всей ее площади в сеть архаичного цитоскелета из микрофиламентов и микротрубочек, со слабыми нековалентными связями своих структурных еАиниц. Такой белково-ионноводный матрикс Аинамически нестабилен при различных воздействиях на клетку, непрерывно перестраивается при полимеризацииАеполимеризации своих нитей, которые собираются из соответствующих молекул и вновь разбираются на отдельные молекулы. Эту полимеризацию и стабилизацию цитоскелета в золе под мембраной обеспечивает гель. Структуры цитоскелета Аистанцируются от мипилов мембраны посредством белковых мостиков, которые связаны как с белкамианкеринами, встроенными в мипиды, так и с неглобулярными белками, состав яяющими основу геля. Поэтому гель, сформированный на цитоскелете, не мешает трансмембранному обмену клеток с окружающей водной средой ни субстратами клеточного метаболизма, ни молекулами воды.

У эукариотов, при наличии органемл и компартментации объема клетки, в сети цитоскелета появцяется его третий элемент - промежуточные филаменты, состоящие из специфических полипептидов. Актин и тубулин эукариотов взаимодействуют с огромным количеством регуляторных, вспомогательных, моторных и Аругих белков. Именно актин явцяется «чемпионом» среди эукариотических белков по количеству белков-партнеров [3]. Интенсивность метаболизма актинмиозиновых, тубулиновых и актинсвязывающих белков обеспечивается ритмом фазовых переходов золь-гель - гель-золь. Силы, Аействующие межАу белками цитоскелета и жилкой фазой геля цитоплазмы клетки - ван-дер-ваальсовые силы, гилрофобные взаимодействия, водородные связи, кулоновские взаимодействия между участками заряженных белковых сетей и окружающих их ионов, обеспечивают упорядоченность расположения компонентов клетки, формируя цитоскелет клетки, подАерживающий ее форму и все формы подвижности, транспортирующий моторными белками ее органелАы, участвующий в ее рецепторной функции и существенно повышающий устойчивость клеток к разрушающим воздействиям на них сАвиговыми течениями в окружающей водной среде.

\section{5. ГЕАЕВЫЕ ТРАНСПОРТНЫЕ СТРУКТУРЫ В ЦИТОП ААЗМЕ}

Известна характерная особенность цитоплазмы эукариотической клетки постоянное внутриклеточное Авижение (циклоз) процессов новообразования и распада разАичных веществ, пульсации микроструктур, постоянно илущие ритмы золь-гель переходов даже в стационарных состояниях отсутствия функциона^ьной активности, т.е. в состоянии 
покоя клетки. Транспорт веществ в цитоплазме реализуется, как известно, посредством эндоплазматической сети - системой Алинных ветвящихся канальцев, пронизывающих цитоплазму; непрерывных полостей, по которым перемещаются вещества, способствуя протеканию разнообразных процессов в различных компартментах клетки. Участвует в транспорте и цитоскелет посредством своих тубулиновых микротрубочек, обеспечивающих перенос гидрофобных молекул межАу отдельными внутриклеточными компартментами с помощью моторных белков и белков-переносчиков [34].

ОАнако объяснить направленный перенос внутри клетки веществ, согласование циклов метаболизма, встречи фермент-субстрат и т.А. этими путями вместе с простой Аиффузией и броуновским Авижением водорастворимых молекул невозможно. Такой транспорт эффективно, с минимальными потерями, осуществляют специальные каналы, образованные гелевыми структурами $[13,14$, 16], заполненные золем, в котором Авижутся метаболиты. На рис. 2 из книги Аж.Пол^ака [16] схематически изображен канал в гелиевой массе, полученный в эксперименте Т.Хираи [17]. Канал окружен слоем структурированной воды в жилкокристалАическом состоянии (4-я фаза Помлака), внутри канала движется золь с микросферами, содержащими метаболиты. Такие каналы в конечном итоге обеспечивают в клетках эффективный перенос водными потоками биологически активных веществ из мест их синтеза в удаленные области цитоплазмы, где они наиболее продуктивно осуществцяют свои функции.

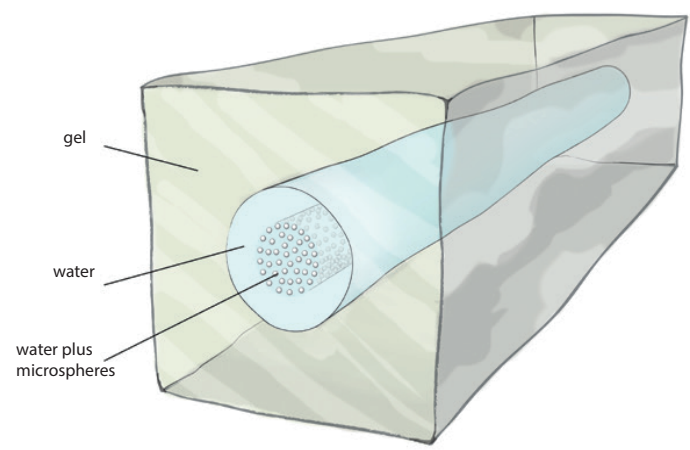

Рис. 2. Гелиевьй канал в уитоплазме клетки (схема) [16].

\section{6. ГЕАЬ КАК СРЕАСТВО ОБЕЗВОЖИВАНИЯ ЦИТОПААЗМЫ}

Специальные каналы, образованные гелевыми структурами, работают на основе несбалансированности потоков воды из клетки наружу и, наоборот, извне в клетку на отАельных участках цитомембраны, иногда весьма удалённых Аруг от Аруга. Интенсификация метаболических процессов клетки, связанных с синтезом веществ в примембранных областях, может мокально повышать осмолярность водной среды в этих областях и нарушать баланс потоков воды через мембрану с доминированием входящих в клетку потоков. С Аругой стороны, смещение баланса водных потоков может быть вызвано изменением напряженности электрического поля в АипиАах мембраны на отдельных ее участках, вызывающим асимметрию проницаемости мембран Аля Аипольных соединений, и прежле всего - воды (эффект Чарахчьяна [33]). При ослаблении поля (например, при ассоциировании с мембраной крупных органических молекул) будет преобладать входящий в клетку поток. В Аругих местах мембраны, свободных от ассоциатов, может сложиться обратная ситуация. Здесь напряженность электрического поля в мипидах намного выше, чем на участках мембораны с ассоциированными крупными частицами. В этом случае будет преобладать поток воды из клетки наружу. Как следствие, появилась возможность реализовывать условия, когАа на одних участках мембраны вода «закачивается» в цитоплазму, а на Аругих участках, порой весьма удаленных от первых, вода, наоборот, «выкачивается» из цитоплазмы. Именно Аанный феномен позволяет использовать структуры из геля Аля формирования транспортных каналов Аля потоков воды [16, 34].

На базе упомянутых выше эффектов возникли механизмы обезвоживания цитоплазмы. Формирование режима спорообразования, в основе которого ^ежит этот эффект, обеспечило одноклеточным организмам выживаемость в периоды засухи. Многоклеточные растения используют этот эффект в формировании семян и зародышей. Эффект обезвоживания и заполнения клеток кожи гелем с послеАующим их высыханием и шелушением имеет место как при образовании серебристого слоя кожи человека в норме, так и при развитии патологий, таких как псориаз и экзема. 


\section{7. ЗАКАЮЧЕНИЕ}

В работе рассматривается возможный вариант появления на безкислородном этапе абиогенеза разделения "цитозоля" первых протоклеточных образований - липидных везикул в первичной гилросфере планеты на Аве фазы - золь и гель. Это разделение явилось решающим фактором оптимизации всех процессов метаболизма в нарождающихся клеточных структурах. Показано формирование механизмов с участием золь-гель структур эволюционных преобразований, которые обеспечили клеткам следование генеральной Аинии эволюционного развития живых систем, а именно неукцонную интенсификацию их энергетического метаболизма. Выявлены принципы и полезные следствия действия таких механизмов. Показана роль геля в формировании и функционировании цитоскелета, а также в формировании оптимальных структур транспорта метаболитов. Обозначены возможности использования структур из геля Аля временной остановки метаболизма клеток (в режимах обезвоживания цитоплазмы) в условиях, неблагоприятных Аля их жизнедеятельности.

Проведенный анализ охватывает огромный период времени - от появления в протоклеточных образованиях первых структур из геля и вплоть АО эволюционного развития и формирования мира эукариотов. Аанный анализ является в известной степени схематичным и носит скорее постановочный характер, но это не умаляет его значимости. Основным результатом представляется выяв Аение основной функции эволюционно ранней структуры из геля - оптимизацию и интенсификацию энергетического метаболизма клетки

\section{МИТЕРАТУРА}

1. Huxley TH. On the Physical Basis of Life. Fortnightly Review, 1869, 5:129.

2. Гейльбрун $\Lambda$. Аинамика живой протоплазмы. Москва, ИА, 1957, 348 с.

3. Attwood TK, Campbell PN, Parish JH, Smith AD, Stirling JL, Vella F, Cammack R (eds). Oxford dictionary of biochemistry and molecular biology. Oxford, UK, Oxford University Press, 2006, 736 p.

4. Албертс Б, Брей $А$, Аьюис Аж, Рэфф М, Робертс К, Уотсон Аж. Молекулярная биология клетки. Т. 2. Москва, Мир, 1994, 541 с.

5. Аьюин Б, Кассимерис $\Lambda$, Аингаппа ВР, Пцоппер Аж (eds.). Клетки. Москва, БИНОМ Ааборатория знаний, 2011, 951 с.
6. Goodacre R, Vaidyanathan S, Dunn WB, Harrigan GG, Kell DB. Metabolomics by numbers: acquiring and understanding global metabolite data. Trends in biotechnology, 2004, 22(5):245-252.

7. Bright GR, Fisher GW, Rogowska J, Taylor DL. Fluorescence ratio imaging microscopy: temporal and spatial measurements of cytoplasmic $\mathrm{pH}$. The Journal of cell biology, 1987, 104(4):1019-1033.

8. Verkman AS. Solute and macromolecule diffusion in cellular aqueous compartments. Trends in biochemical sciences, 2002, 27(1):27-33.

9. Weiss JN, Korge P. The cytoplasm: no longer a wellmixed bag. Circulation research, 2001, 89(2):108-110.

10. Ellis RJ. Macromolecular crowding: obvious but underappreciated. Trends in biochemical sciences, 2001, 26(10):597-604.

11. Luby-Phelps K. Cytoarchitecture and physical properties of cytoplasm: volume, viscosity, diffusion, intracellular surface area. International review of cytology, 2000, 192:189-221.

12. Persson E, Halle B. Cell water dynamics on multiple time scales. Proceedings of the National Academy of Sciences of the United States of America, 2008, 105(17):6266-6271.

13. Аинг Г. Физическая теория живой клетки: незамеченная революиия. СПб, Наука, 2008, 376 с.

14. Полмак АжХ. Клетки, гели и двигатели жизни. Новый объединительныи подход к функиии клеток. Екатеринбург, Токмас-Пресс, 2009, 386 с.

15. Загускин СА, Никитенко АА, Овчинников ЮА, Прохоров АМ, Савранский ВВ, Аегтярева ВП, П^атонов ВИ. О диапазоне периодов колебаний микроструктур живой клетки. Аокл. АН СССР, 1984, 277(6):1468-1471.

16. Pollack GH. The Fourth Phase of Water: Beyond Solid, Liquid, and Vapor. Seattle, Ebner\&Sons Publ., 2013.

17. Suzuki D, Kobayashi T, Yoshida R, Hirai T. Soft actuators of organized self-oscillating microgels. Soft Matter, 2012, 8(45):11447-11449, DOI: 10.1039/ C2SM26477C.

18. Giudice E. Del, Tedeschi A, Vitiello G, Voeikov V. Coherent structures in liquid water close to hydrophilic surfaces. Journal of Physics: Conference Series, 2013, 442(012028):1-5.

19. Воейков В.А. Активный кислород, организованная вода и процессы жизнедеятельности. Труды II межс. конгресса "Слабъе и сверхслабъге поля и излученя в биологии и медичие». СПб.: Тускарора, 2000, с. 1-4.

20. Pershin SM, Bunkin AF. Observation of temperature evolution of relative concentration ortho/para spinisomers $\mathrm{H}_{2} \mathrm{O}$ by four-photon spectroscopy. Laser Physics, 2009, $19(7): 1-5$.

21. Зарицкий АР, Грачев ВИ, Воронцов ЮП, Пронин ВС. Энергетические аспекты абиогенеза в атмосфере на нанокаплях углеводородного аэрозоля. Радиоэлектроника. Наносистемы. Информачионные технологии (РЭНСИТ), 2013, 5(2):105-125.

22. Зарицкий АР, Грачев ВИ, Воронцов ЮП, Пронин BC. Абиогенез на этапе перехода из атмосферы в водную среду: от везикул к протоклеткам. Радиоллекроника. Наносистемьг. Информачионные технологии (РЭНСИТ), 2014, 6(2):221-231; DOI: 10.17725/RENSITe.0006.201412f.0221.

23. Зарицкий АР, Пронин ВС. Биофизика основных режимов клеточного метаболизма. Функциональные 
режимы клетки: состояние покоя и активность. Краткие сообщения по физике ФИАН, 2006, 12:8-18.

24. Зарицкий АР, Пронин ВС. Биофизика основных режимов клеточного метаболизма. Режим Аеления клетки (митоз). Краткие сообщения по физике ФИАН, 2006, 12:19-27.

25. Зарицкий АР, Грачев ВИ, Воронцов ЮП, Кириченко $\mathrm{MH}$, Пронин ВС. Анаэробный этап эволюционного развития животной клетки. Радиоэлектроника. Наносистемы. Информачионные технологии (РЭНСИТ), 2015, 7(1):87-99; DOI: 10.17725/RENSITe.2015.07.087.

26. Doolittle WF, Zhaxybayeva O. On the Origin of Prokaryotic Species. Genome Res., 2009, 19:744-756.

27. Lepeschkin WW. My opinion about protoplasm. Protoplasma, 1930, 9:269.

28. Гурвич АГ. Проблема митогенетического излучения как аспект молекулярной биологии. АенинграА, Медицина, 1968, 240 c.

29. Казначеев ВП, Михайлова АП. Сверхслабые излучения в межклеточныг взаимодействиях. Новосибоирск, Наука, 1981, 144 с.

30. Бурлаков АБ, Бурлакова ОВ, Голиченков ВА. Аистантные взаимодействия разновозрастных эмбрионов вьюна. $\triangle A H, 1999,368(4): 562-564$.

31. Бурлаков АБ, Бурлакова ОВ, Голиченков ВА. Возможность изменения индивидуального биологического времени слабыми электромагнитными изцучениями. Труды $V$ межд. конгресса "Слабъге и сверхслабые поля и излучения в биологии и медичине" (29.6-3.7.09), Санкт-Петербург, РГГМУ, 2009, c. 41-47.

32. Сайт конгресса "Слабые и сверхслабые поля и излучения в биологии и медиине", Санкт-Петербург, Россия: http://www.biophys.ru/congress-2015.
33. Зарицкий АР, Зайцева ГВ Грачев ВИ, Кириченко МН. Электрическое поле в цитомембране как фактор интенсификации метаболизма клеток. Радиоэлектроника. Наносистемыл. Информачионные технологии (РЭНСИТ), 2016, 8(1):91-103, DOI: 10.17725/rensit.2016.08.91.

34. Gitai Z. The new bacterial cell biology: moving parts and subcellular architecture. Cell, 2005, 120(5):577-586.

Зарицкий Александр Романович

c.H.C.

Физический институт им. П.Н.Аебедева РАН 53, Аенинский пр., 119991 Москва, Россия zaritsky@sci.lebedev.ru.

Грачев Владимир Иванович ил.-корр. РAEH

ИРЭ им. В.А.Котельникова РАН

11/7, ум. Моховая, 125009 Москва, Россия grachev@cplire.ru.

Зайцева Гамина Вцадимировна

M.H.C.

Физический институт им. П.Н.Аебедева РАН

53, Аенинский пр., 119991 Москва, Россия

zaytseva-gv@yandex.ru.

Кириченко Марина Никомаевна

к.ф.-M.н., н.с.

Физический институт им. П.Н.Аебелева РАН

53, Аенинский пр., 119991 Москва, Россия maslova marina@mail.ru.

\section{EVOLUTIONARY ASPECTS OF THE GEL APPEARANCE AND ITS FUNCTIONS IN THE CELL CYTOPLASM}

\section{Alexander R. Zaritsky, Galina V. Zaytseva, Marina N. Kirichenko}

Lebedev Fizichesky Institute, Russian Academy of Sciences, http://www.lebedev.ru

119991 Moscow, Russian Federation

\section{Vladimir I. Grachev}

Kotelnikov Institute of Radio Engineering and Electronics, Russian Academy of Sciences, http://www.cplire.ru 125009 Moscow, Russian Federation

Abstract. In this paper we consider a well-known phenomenon in the life and the evolutionary development of animal cells - the presence in their cytoplasm gel. Described the evolution of the gel appearance with the dynamics of sol-gel phase transitions. Substantiated the main function of the gel in the cytoplasm - providing intensification of the energy metabolism of cells. Shown the role of the gel in the infrastructure of the cell and its compartments, the relationship of the gel and the cytoskeleton, promoting transmembrane exchange of cell with the environment. Shown the role of gel channels in the logistics of water flows and active substances in the cytoplasm, in the regulation of metabolic mechanisms, in particular, in the regulation of the cytoplasm dehydration modes - of sporulation in unicellular organisms and of the drying of human dermal cover in the norm and in various pathologies. Keywords: cytoplasm, sol, gel, structured water, energy metabolism, cytoskeleton, gel channels, waterways, dehydration mechanisms

PACS: $87.32 . \mathrm{Kg}$ 


\section{ГРАФЕНИКА. РОССИЙСКИЙ СЕМИНАР С.П. ГУБИНА (МОСКВА)}

\section{Буслаева Елена Ю.}

ВНИИА^маз, http://www.vniialmaz.ru/, ООО АкКоАаб, http://www.akkolab.ru

107996 Москва, Российская Федерация

Институт общей и неорганической химии им. Н.С.Курнакова РАН, http:/ /www.igic.ras.ru

117901 Москва, Российская Федерация

eyubuslaeva@inbox.ru

Российский семинар «ГРАФЕН: МОАЕКУАА И КРИСТААА (материал, физика, химия, эмектроника, фотоника, биомедицинские применения)» поА руководством А.х.н., проф. С.П. Губина работает с ноября 2011 года. Семинары проходят раз месяц, в основном, в конференц-зале ВНИИАлмаз на ул. Гимяровского, дом 65. Семинар проводится при подАержке ООО «АкКоАаб» и ВНИИ «ААМАЗ». Программы семинаров размещены на сайте: http://www.akkolab.ru. Организаторы семинара виАят его как Аискуссионную платформу дмя обсуждения новых идей и концепций, ознакомления с результатами и обмена опытом работы исследователей в бурно развивающейся графенике - межАисциплинарной области современной науки. ПреАполагается издание ежегодного Сборника материалов семинара, создание Программы исследований в этой области с возможным выходом на финансирование. В работе семинара принимают участие сотрудники разАичных научных УчрежАений г.МосквЫ - ИОНХ РАН, ИНЭОС РАН, ИХФ РАН, ИРЭ РАН, НИЦ Курчатовский ин-т, МГУ Химфак, МФТИ, НИЯУ МИФИ, РУАН, ООО «Акколаб», ОАО «ВНИИ ААМАЗ», ООО «КарбонАайт», ОАО «НИИграфит» и Ар., а также приглашенные сотрудники научных учрежАений России, стран СНГ и зарубежья. Аудитория кажАого заседания - около полусотни участников. На четырехчасовом заседании с перерывом заслушиваются и обсуждаются 3-4 доклада, обзор новостей, представленные стендовые сообщения.В журнале РЭНСИТ публикуются полугодовые отчеты о работе семинара: перечень докладов с указанием аффилированных авторов и представленные тезисы докцадов.

УАК 061.3

РЭНСИТ, 2016, 8(2):223-224

\section{5 СЕМИНАР, 13.10.2016}

1. «Перспективные приборы нано- и оптоэлектроники на основе графеновых гетероструктур» к.ф.-м.н. А.А.Свинцов, B.В.Вьюрков, В.И.Рыжий, Т.Otsuji (МФТИ, ФТИАН РАН, Tohoku Univ., Sendai, Japan).

Уникальные электронные свойства графена и оптические свойства слоистых полупроводников могут быть с успехом объединены в новых композитных материалах, называемых ван-дер-ваальсовыми гетероструктурами. В Аокладе будет представлен обзор приборов нано- и оптоэлектроники на основе Аанных гетероструктур: как реально функционирующих, так и планируемых к реализации. Особое внимание будет уделено приборам на основе резонансного туннелирования: туннельным транзисторам, каскадным ИК фотодетекторам и источникам терагерцового изцучения. В докладе будет показано, каким образом «релятивистский» спектр носителей заряда в графене позволяет радикально улучшить характеристики приборов на основе графеновых структур по сравнению с аналогами на основе соединений AIIIBV.

2. «Прямой синтез гиАрированного графена в термической пиазме» Р.Х.Амиров, Э.Х.Исакаев, к.т.н. М.Б.Шавелкина (ОИВТ РАН). Показана возможность прямого синтеза гиАрированных графеновых материалов в плазмоструйном реакторе. Материалы получены в свободном состоянии при разложении углеводородов с помощью плазмотрона постоянного тока при Аавлении близком к атмосферному. Элементный анализ, сканирующая электронная микроскопия, спектроскопия комбинационного рассеяния света и ренттеновская фотоэлектронная спектроскопия показали, что в синтезированных малослойных образцах присутствует водород в соотношении с углеродом 1:4. При нагревании образцов происходит выделение водорода, что проицАюстрировано термогравиметрией в атмосфере инертного газа.

3. «Гибридные 2D/3D нанокомпозиты на базе графена с позиции применения в опто- и эмиссионной эмектронике» А.ф.м.н., проф. О.Е.Г цухова (Саратовский университет).
Исследованы оптические и электронные свойства гибридного $2 \mathrm{D}$ нанокомпозитного графен-нанотрубного материала и новой топологической формы пористого стеклоподобного углеродного 3D материала, образованного графеновыми чешуйками и фулмереновыми фрагментами. Методами моделирования выступили молекулярно-механический метоА AIREBO и квантовый метод SCC DFTB2. Статические исследования проведены с помощью программного пакета DFTB+ (http://www.dftb-plus. info), Аинамические - с помощью отечественного open source KVAZAR (http://nanokvazar.ru). Установлены термодинамически стабильные формы 2D- графен-нанотрубного композита, структурными компонентами которого явцяются нанотрубки типа $(\mathrm{n}, 0)$, расположенные между Авумя монослоями графена и связанные с ними ковалентно $(n=10,12,14,16,18,20)$. Рассчитанные зонные структуры показали, что композит обладает типом проводимости, характерным Аля полуметаллов (подобно графену). Исключение состав яет топологическая модель композита с трубками $(10,0)$, проводимость которого носит полупроводниковый характер с щелью в зонной структуре 0,08-0,1 эВ в зависимости от шага Аистанцирования трубок.

26 СЕМИНАР, 15.12.2016

1.«Высокочувствительный акустоэлектрический датчик влажности со слоем оксида графена» А.ф-м.н., проф. РАН Ирен Евгеньевна Кузнецова (ИРЭ РАН).

2. С.П.Червонобродов, к.ф.-м.н. Сообщение о круглом столе на Международном Конгрессе «Возобновляемая энергетика XXI век: энергетическая и экономическая эффективность». Сколково, 1314.10.16. «Могут ми углеродные материалы (на основе графена) принципиально менять энергоемкость Аюбых электрохимических устройств?».

3.«Физико-химические аспекты функционализации и модифицирования углеродных наноматериалов» к.х.н. Т.П.Аьячкова (Тамбовский государственный технический университет). 


\section{GRAFENIKA [GRAPHENICS]}

\section{RUSSIAN GUBIN'S SEMINAR (MOSCOW)}

Elena Yu. Buslaeva

VNIIAlmaz, http://www.vniialmaz.ru/, Ltd. AkKoLab, http://www.akkolab.ru

107996 Moscow, Russian Federation

Kurnakov Institute of General and Inorganic Chemistry, Russian Academy of Sciences, http://www.igic.ras.ru

117991 Moscow, Russian Federation

eyubuslaeva@inbox.ru

Russian Seminar "GRAPHENE: MOLECULE AND CRYSTAL (material, physics, chemistry, electronics, photonics, biomedical applications)" under the direction of prof. SP Gubin operates from November 2011. Seminar sessions are held once a month, mainly in the boardroom VNIIAlmaz in Gilyarovskogo str., 65 (metro station "Rizhskaya"). The seminar is supported by LLC "AkKoLab" and the VNIIAlmaz. Programms of seminars are available at http://www.akkolab.ru. The seminar organizers see it as a discussion platform to discuss new ideas and concepts, review the results and the exchange of experience of researchers in the booming grafenika - an interdisciplinary field of modern science. Anticipated publication of an annual compendium of seminar materials, creating Programs of research in this area with possible access to financing. The seminar was attended by officials from various scientific institutions of Moscow - Kurnakov Institute of General and Inorganic Chemistry RAS, Nesmeyanov Institute of Organoelement Compounds of RAS, Semenov Institute of Chemical Physics RAS, Kotel'nikov Institute of Radio Engineering and Electronics RAS, National Research Centre "Kurchatov Institute", Moscow State University Department of Chemistry, Moscow Institute of Physics and Technology, National Research Nuclear University "MEPhI", People's Friendship University of Russia, LLC "AkKoLab", Open Joint Stock Company (JSC) "VNII ALMAZ", LLC "Karbonlayt", JSC NIIgrafit and others, as well as invited members of scientific institutions in Russia, Commonwealth of Independent States (CIS) and foreign countries. The audience for each session - about fifty participants. In the four- hour meeting with a break heard and discussed the 3-4 reports, news review and submitted poster presentations.

The journal RENSIT is published semi-annual reports of this seminar: list of reports indicating affiliated authors and submitted abstracts.

PACS: $01.10 \mathrm{Fv}$

RENSIT, 2016, 8(2):223-224

DOI: $10.17725 /$ rensit.2016.08.223

\section{5th SEMINAR, 13.10.2016}

1. Svintsov DA (PhD Phys\&Math), V'yurkov VV, Ryzhii VI, T. Otsuji. (MIPT, FTI RAN, Tohoku Univ., Sendai, Japan). Promising devices for nano - and optoelectronics based on graphene heterostructures

2. Amirov RKh, Isakaev EKh, Shavelkina MB (PhD Tech) (JIHT RAS). Direct synthesis of hydrogenated graphene in thermal plasma.

3. Glukhova OE (Dr Sci Phys\&Math, Saratov Univ.). Hybrid 2D/3D nanocomposites based on graphene with a position of application in opto - and emission electronics.

\section{6th SEMINAR, 15.12.2016}

1.Kuznetsova IE (Dr Sci Phys\&Math, prof RAS, IRE RAS). Highly sensitive acoustoelectric sensor of humidity with a layer of graphene oxide.

2. Chervonoborodov SP (PhD Phys\&Math). The message about the round table at the International congress "Renewable energy XXI century: energy and economic efficiency." Skolkovo, 13-14 Oct 2016. "Can carbon materials (graphene-based) is fundamentally changing the energy of any electrochemical devices?

3. D'yachkova TP (PhD Chem, Tambov GTU). Physico-chemical aspects of functionalization and modification of carbon nanomaterials. 